\title{
Archaeology at the Alamodome: Investigations of a San Antonio Neighborhood in Transition, Volume I: Historical, Architectural, and Oral History Research
}

Anne A. Fox

Center for Archaeological Research

Marcie Renner

Center for Archaeological Research

Robert J. Hard

Department of Anthropology, University of Texas at San Antonio

Follow this and additional works at: https://scholarworks.sfasu.edu/ita

Part of the American Material Culture Commons, Archaeological Anthropology Commons, Environmental Studies Commons, Other American Studies Commons, Other Arts and Humanities Commons, Other History of Art, Architecture, and Archaeology Commons, and the United States History Commons

Tell us how this article helped you.

This Article is brought to you for free and open access by the Center for Regional Heritage Research at SFA ScholarWorks. It has been accepted for inclusion in Index of Texas Archaeology: Open Access Gray Literature from the Lone Star State by an authorized editor of SFA ScholarWorks. For more information, please contact cdsscholarworks@sfasu.edu. 
Archaeology at the Alamodome: Investigations of a San Antonio Neighborhood in Transition, Volume I: Historical, Architectural, and Oral History Research

\section{Creative Commons License}

(c) (1) (8)

This work is licensed under a Creative Commons Attribution-NonCommercial 4.0 International License 


\section{Archaeology at the Alamodome: Investigations of a San Antonio Neighborhood in Transition}

edited by Anne A. Fox, Marcie Renner, and Robert J. Hard

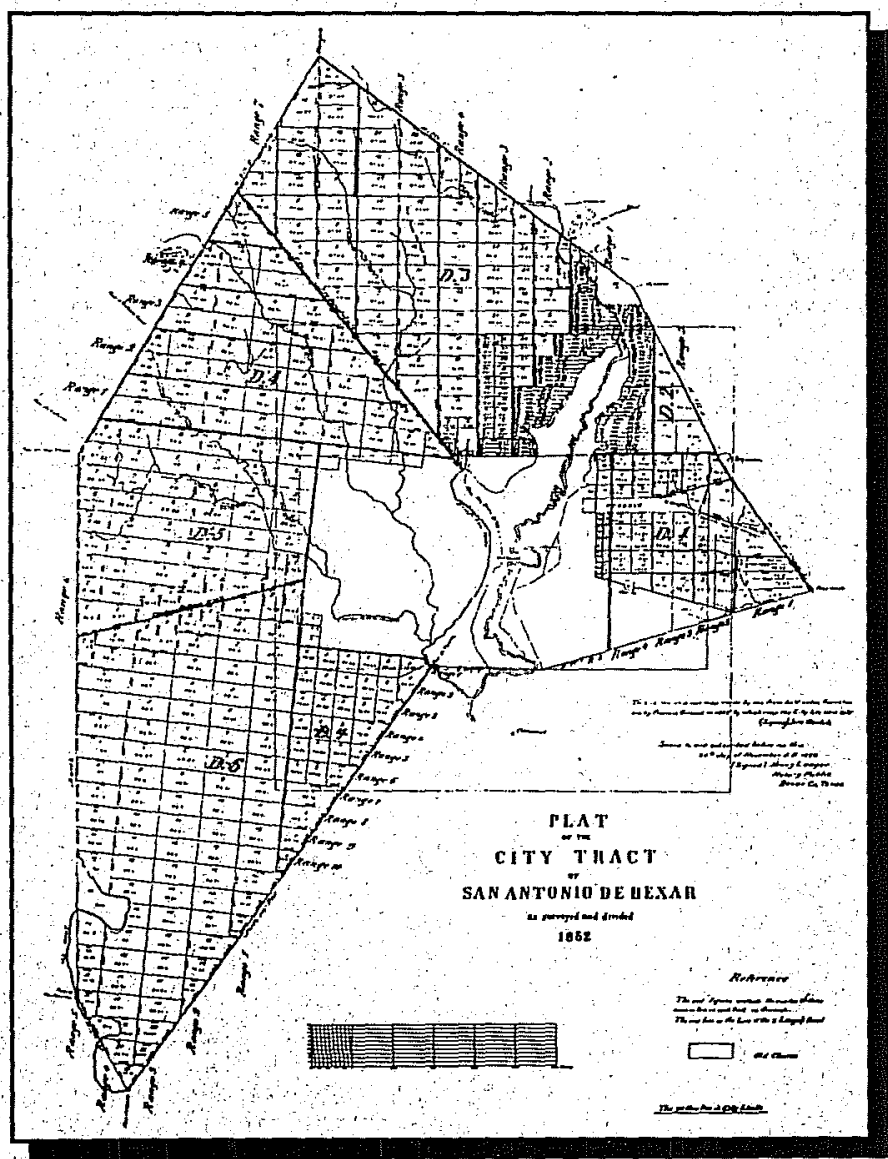

Volume I

Historical, Architectural, and Oral History Research

contributors:

Andrew Perez Associates, I. Waynne Cox, Anne A. Fox, Kevin J. Gross, Shirley Boteler Mock, Maria W. Pfeiffer, Herbert G. Uecker, and G. Kenneth Wright

Center for Archaeological Research, The University of Texas at San Antonio Archaeological Survey Report, No. 236, 1997 



\title{
Archaeology at the Alamodome: Investigations of a San Antonio Neighborhood in Transition
}

edited by Anne A. Fox, Marcie Renner, and Robert J. Hard

\section{Volume I}

\section{Historical, Architectural, and Oral History Research}

\author{
contributors:
}

Andrew Perez Associates, I. Waynne Cox, Anne A. Fox, Kevin J. Gross, Shirley Boteler Mock, Maria W. Pfeiffer, Herbert G. Uecker, and G. Kenneth Wright

Robert J. Hard, Jack D. Eaton, and Anne A Fox, Principal Investigators

Texas Antiquities Permit Numbers 900, 930, and 982

$$
\text { ๑copyright }
$$

Center for Archaeological Research

The University of Texas at San Antonio

Archaeological Survey Report, No. 236 
The following information is provided in accordance with the General Rules of Practice and Procedure, Chapter 41.11 (Investigative Reports), Texas Antiquities Committee:

1. Type of investigation: Survey, testing, and mitigation

2. Project name: Alamodome

3. County: Bexar

4. Principal investigators: Robert J. Hard, Jack D. Eaton, and Anne A. Fox

5. Name and location of sponsoring agency: City of San Antonio, P.O. Box 839966, San Antonio, Texas 782833966

6. Texas Antiquities Committee Permit Nos.: 900, 932, and 982

7. Published by the Center for Archaeological Research, The University of Texas at San Antonio, San Antonio, Texas 78249-0658, 1997

A list of publications offered by the Center for Archaeological Research is available. Call (210) 458-4378; write to the Center for Archaeological Research, The University of Texas at San Antonio, 6900 N. Loop 1604 W., San Antonio, Texas 78249-0658; e-mail to car@lonestar.utsa.edu; or visit CAR's Web site at http://www.csbs.utsa.edu/research/car/index.htm. 


\section{Contents}

List of Figures $\ldots \ldots \ldots \ldots \ldots \ldots \ldots \ldots \ldots \ldots \ldots \ldots \ldots \ldots \ldots \ldots \ldots \ldots \ldots$

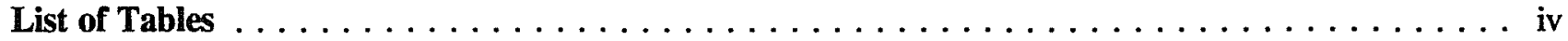

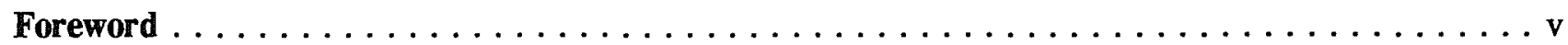

Chapter 1: Project Setting, Phases, and Methodology

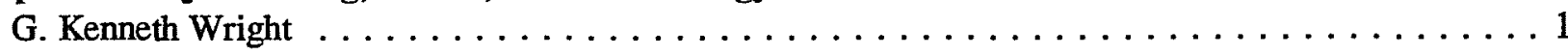

Chapter 2: The Growth of San Antonio

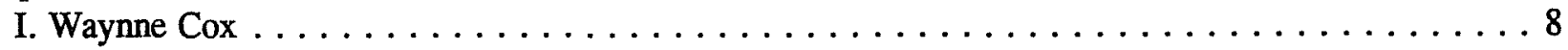

Chapter 3: An Architectural Study

Introduction

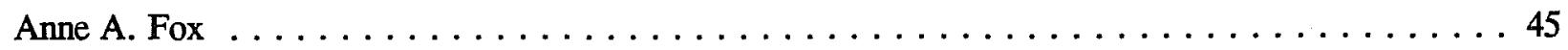

Architectural Inventory and Assessment

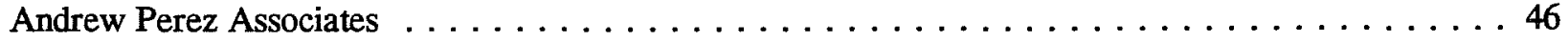

Domestic Architecture in San Antonio

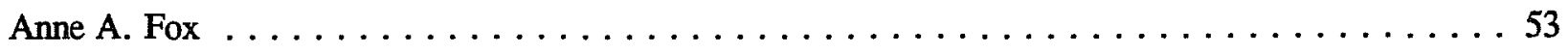

Standing Structures in the Alamodome Impact Area

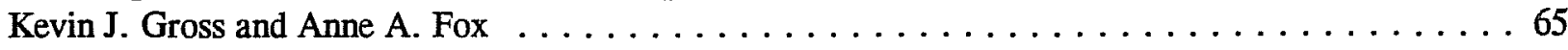

Chapter 4: Oral History Research

Maria W. Pfeiffer . . . . . . . . . . . . . . . . . . . . . 70

Chapter 5: San Antonio, Texas, 1900-1940: A Period of Mutual Aid

Shirley Boteler Mock . . . . . . . . . . . . . . . . . . . . . . . . 84

Chapter 6: Urban Structural Evolution at the Alamodome Development Site: 1850-1950

Herbert G. Uecker . . . . . . . . . . . . . . . . . . . . . . . . . . 114

Chapter 7: Summary

Kevin J. Gross and Anne A. Fox 


\section{Figures}

1-1. Location of the Alamodome Project (shaded area) $\ldots \ldots \ldots \ldots \ldots \ldots \ldots \ldots \ldots \ldots$

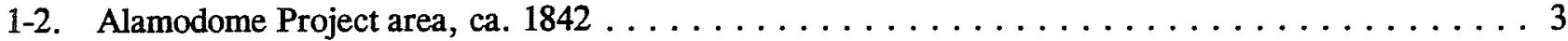

1-3. Building development in the project area $1850-1950 \ldots \ldots \ldots \ldots \ldots \ldots \ldots \ldots \ldots$

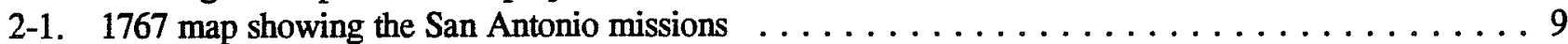

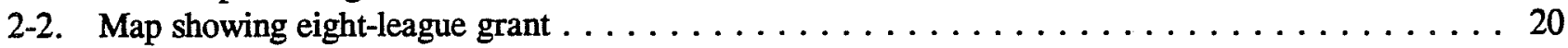

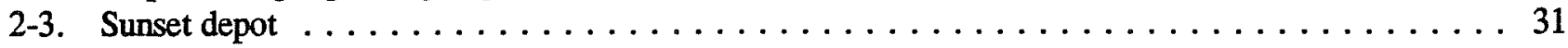

2-4. Looking north on St. Mary's Street during the flood of September $1921 \ldots \ldots \ldots \ldots \ldots \ldots . . \ldots 5$

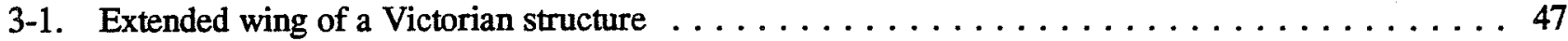

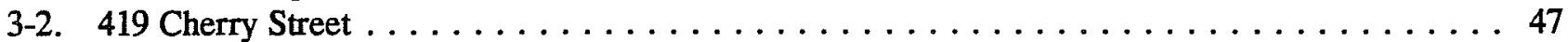

3-3. Southern Pacific Railroad Station, front facade $\ldots \ldots \ldots \ldots \ldots \ldots \ldots \ldots \ldots \ldots$. 48

3-4. Southern Pacific Railroad Station, west facade $\ldots \ldots \ldots \ldots \ldots \ldots \ldots \ldots \ldots \ldots \ldots$

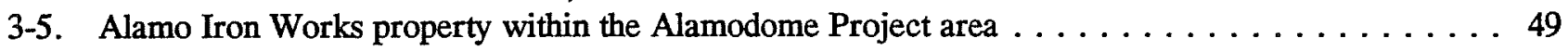

3-6. Alamo Iron Works, Corporate Office Building $\ldots \ldots \ldots \ldots \ldots \ldots \ldots \ldots \ldots \ldots \ldots \ldots$

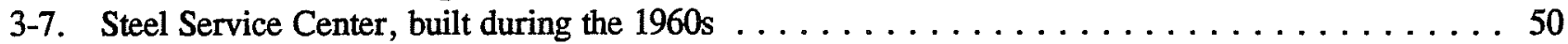

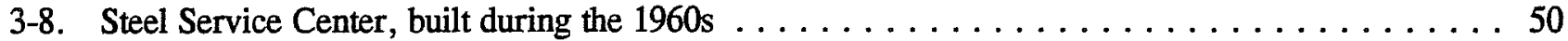

3-9. Alamo Iron Works, the oldest existing shops $\ldots \ldots \ldots \ldots \ldots \ldots \ldots \ldots \ldots \ldots \ldots \ldots$

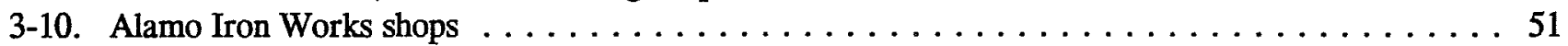

3-11. Main Warehouse and Re-bar Fabrication Shop, south facade $\ldots \ldots \ldots \ldots \ldots \ldots \ldots \ldots \ldots \ldots \ldots \ldots \ldots$

3-12. Main Warehouse and Re-bar Fabrication Shop, north facade $\ldots \ldots \ldots \ldots \ldots \ldots \ldots \ldots \ldots$

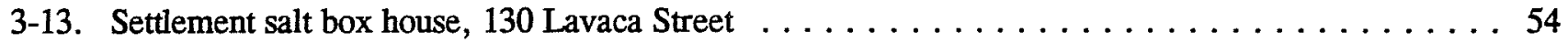

3-14. Augustus Koch's Bird's Eye View of the City of San Antonio, $1873 \ldots \ldots \ldots \ldots \ldots \ldots$

3-15. Augustus Koch's Bird's Eye View of San Antonio, $1886 \ldots \ldots \ldots \ldots \ldots \ldots \ldots \ldots \ldots$

3-16. Diagrammetric sketches of house types in the Alamodome area $\ldots \ldots \ldots \ldots \ldots \ldots \ldots 7$

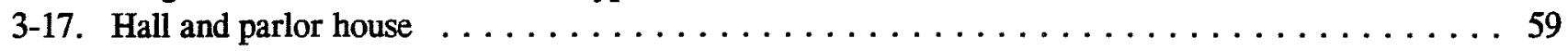

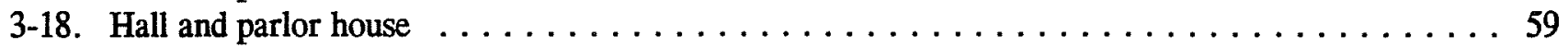

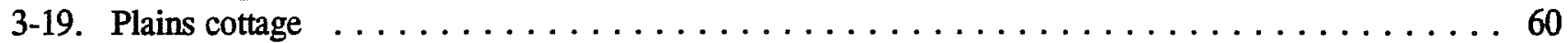

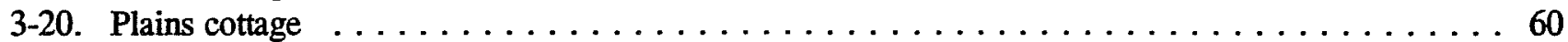

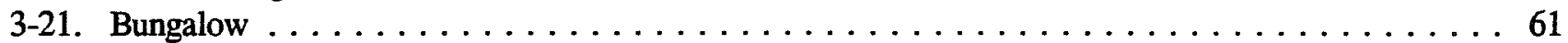

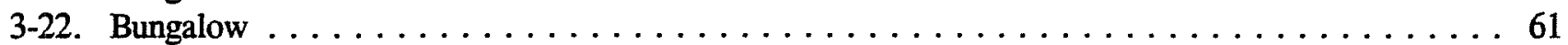

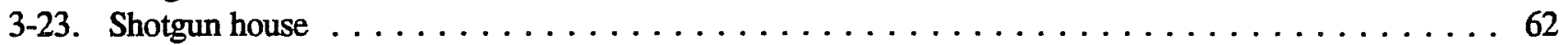

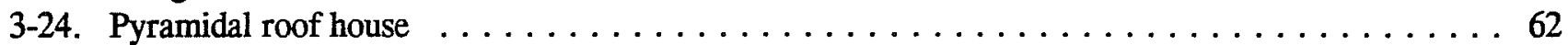

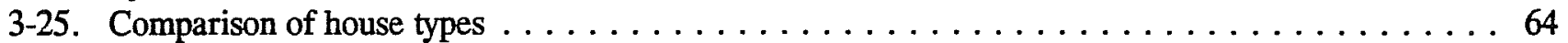

4-1. Alamodome Project area in relation to downtown San Antonio $\ldots \ldots \ldots \ldots \ldots \ldots \ldots$. . . 71

5-1. Small frame bungalow at 123 Runge Street, $1990 \ldots \ldots \ldots \ldots \ldots \ldots$. . . . . . . . . 86

5-2. Shotgun house at 139 Pablo Alley, $1990 \ldots \ldots \ldots \ldots \ldots \ldots \ldots \ldots \ldots \ldots \ldots \ldots$

5-3. Charles Bellinger . . . . . . . . . . . . . . . 92

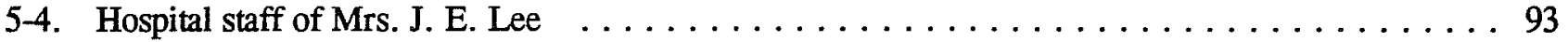

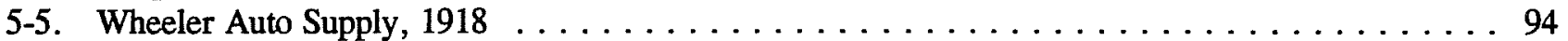

5-6. Cook for the Riegler Confectionery Store, ca. $1915 \ldots \ldots \ldots \ldots \ldots \ldots \ldots \ldots \ldots \ldots$. . . . . . . . 95

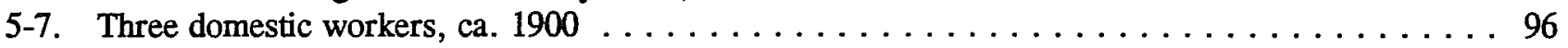

5-8. Unidentified attendant with boys in cart decorated for the Battle of Flowers parade . . . . . . 96

5-9. Witt Leonard's Pharmacy. . . . . . . . . . . . . . . . . . . . . . . . . . . . . . 97

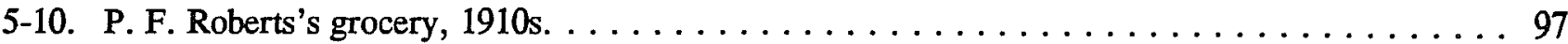

5-11. Bellinger Auto Livery, $1931 \ldots \ldots \ldots \ldots \ldots \ldots \ldots \ldots \ldots \ldots \ldots \ldots \ldots \ldots$ 
5-12. Mt. Zion Baptist Church . . . . . . . . . . . . . . . . . . . . . . 99

5-13. Addie, cook for the Dr. John W. Kenney family, ca. $1909 \ldots \ldots \ldots \ldots$. . . . . . . . . . . 101

5-14. Lillie Brackenridge at Vance residence, ca. $1900 \ldots \ldots \ldots \ldots \ldots$. . . . . . . . . . . 102

5-15. Atlee B. Ayres family with maid in foreground . . . . . . . . . . . . . . . . . . 102

5-16. Women's Progressive Club, ca. 1929 . . . . . . . . . . . . . . . . . . . . . . . . . . . 104

5-17. Preacher baptizing group in San Antonio River, $1914 \ldots \ldots \ldots \ldots \ldots \ldots$. . . . . . . . 107

$6-1$. Plat of the Alamodome Project area $\ldots \ldots \ldots \ldots \ldots \ldots \ldots \ldots \ldots \ldots$

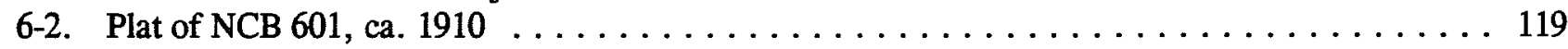

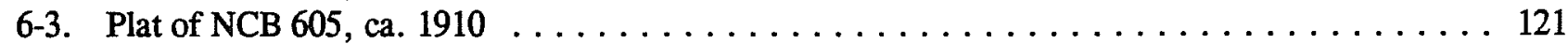

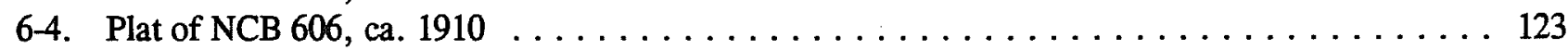

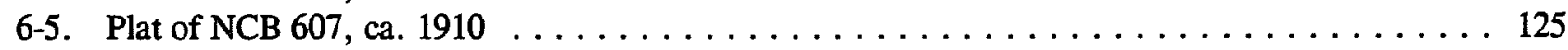

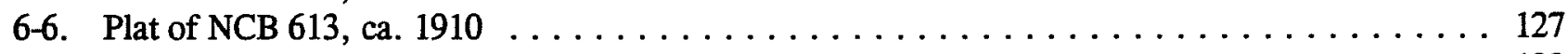

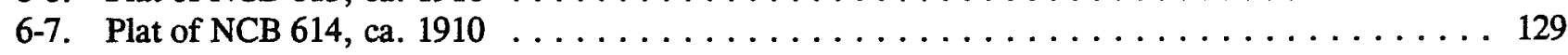

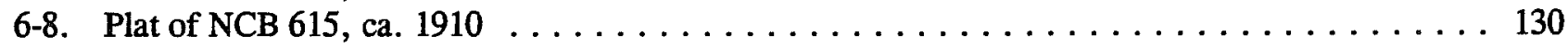

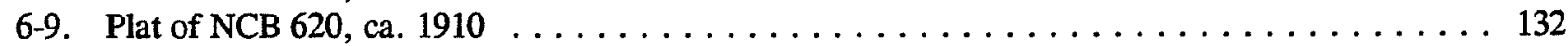

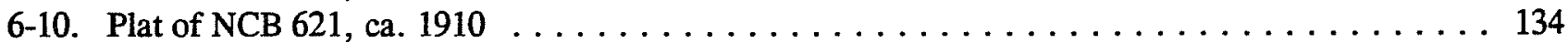

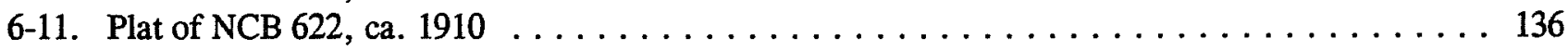

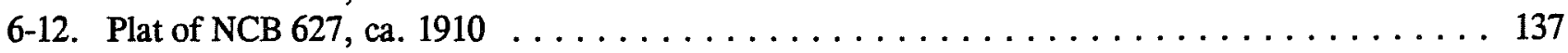

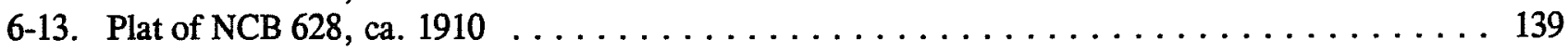

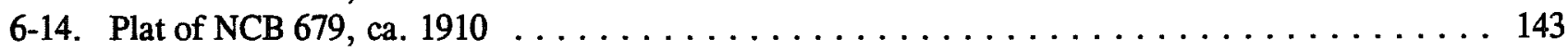

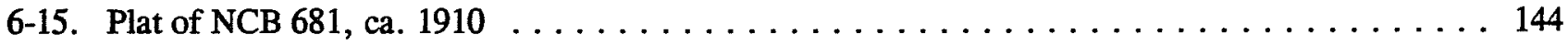




\section{Tables}

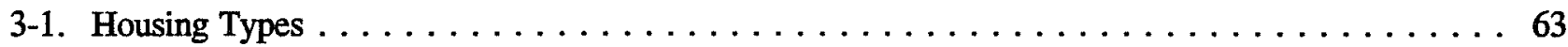

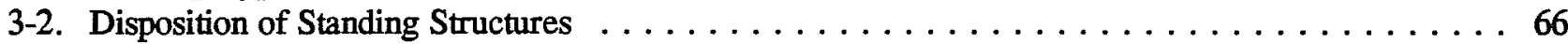

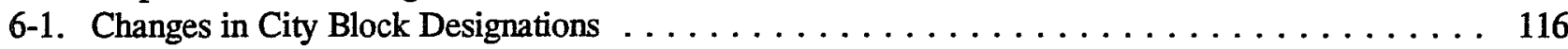

6-2. Data on Selected Nineteenth-Century Residences in NCB $14084 \ldots \ldots \ldots \ldots \ldots \ldots \ldots \ldots . \ldots \ldots$

7-1. Developmental History of Lots in the Alamodome Project Area . . . . . . . . . . . . 149

7-2. Summary of Development of Lots within the Alamodome Project Area . . . . . . . . . . 157

7-3. Summary of Development of Lots within the Alamodome Project Area by Blocks $\ldots \ldots \ldots \ldots 158$

7-4. Percent of Known Site Types in the Alamodome Project Area by Time Period . . . . . . . . . 158 


\section{Foreword}

Because of the tremendous scope of the archaeological work and the associated analysis and write-up, the results of the Alamodome Project are presented in three volumes. This volume, the first of the series, contains the background research results, including chapters on the historical setting, the architecture present before demolition was begun, the oral history, a study of the African-American community, and a summary of the structural evolution of the area. Volume II contains a complete description of the archaeological excavations and a distributional analysis of the results. Included are numerous maps, drawings, and photographs of the work in progress. Volume III is comprised of individual reports on the description and analysis of various types of arifactual materials recovered during the project, including ceramics, glass, kitchen and tablewares, dolls and toys, marbles, clothing and personal items, and building materials. Also included in this volume are descriptions and discussions of excavated wells, cisterns, acequias, and privies, and an analysis of the faunal materials.

The temporal scope of these studies is the 100-year period from 1850 to 1950 . This time frame encompasses the period directly after the end of Spanish/Mexican control and the gradual rise of Anglo/German control of the local economy and sociopolitical structure. It is also the time during which the first wave of the Industrial Revolution arrived in Texas, seriously impacting the history of San Antonio. One goal of the project was to study this impact on the economic and cultural life of one small sector of the city.

\section{Scope of Volume I}

The chapters in this volume contain the results of research into the history of the Alamodome area and the people who lived there. This compiled information was used to make informed decisions about which areas would yield information of importance in understanding and reconstructing on paper the neighborhood that was about to be eliminated, so that its history would not be completely lost. It has also been invaluable in understanding the results of the archaeology reported in Volumes II and III.

In the first chapter, Kenny Wright presents an overall introduction to the project. This chapter includes the environmental setting of the project area, a brief historical overview, and a description of the project phases. Wright also outlines the archival and archaeological methods employed during the Alamodome Project.

Waynne Cox's historical research introduces the major participants in the settlement and development of San Antonio and how they contributed to the process. He shows how the project area was affected by the rapid development of the town in the last half of the nineteenth century, tracing the changes caused by the arrival of the railroad in 1877 and the Steves Lumber Yard and the Holmgreen Foundry (later to become the Alamo Iron Works) in the early 1880s. The slow growth of public acceptance of municipal water and sewer systems coincided with the immigration of new families and the infill of small houses into the sparsely settled neighborhood after 1900 . A sudden increase in rail traffic during World War I brought changes to the character of the area, as the older home owners moved out to be replaced by renters employed by the railroad and the increasing number of local industries. The growth and expansion of the Alamo Iron Works and a gradual change from a residential to an industrial emphasis resulted in the mixed industrial/residential area present at the time of the final demolition. Cox combines the history of events with the political background of the times, producing a coherent narrative of the effects of urban development on one particular neighborhood within the city.

When the area to be impacted by the Alamodome was chosen, the architectural firm of Andrew Perez Associates, under contract with the Center for Archaeological Research, undertook an architectural assessment of the entire project area. This involved photographing every house and commercial structure, studying architectural types represented, and determining dates of construction. This study provides 
a complete catalog of the architecture of an area of the city that has now been totally demolished, which should be of value to future architectural historians. Over 175 photographs were produced by this architectural study. We have used selected portions of the information and photographs in order to compose a discussion of the residential architecture in the study area. The complete photographic report is on permanent file at the CAR laboratory for any researcher seeking further detail. This chapter also provides a summary of the disposition of the standing structures.

Maria Watson Pfeiffer, working for E. L. Fly and Associates, concentrated her oral history research on reconstructing the particular history of the people in the immediate vicinity of the Alamodome. We felt it important to include not just the project area, but also the surrounding neighborhood of which it had been a part, extending to the east across what is now the Interstate 37 expressway, through the HemisFair property, to South Alamo Street. This area has suffered a number of major disruptions during the past 30 years. Of particular importance are the descriptions of structures, business establishments, and ethnic enclaves important to the citizens of the Alamodome area which were eliminated by the construction of Victoria Courts, the HemisFair, and the I-37 expressway, all regrettably done before proper cultural resource surveys were conducted. The full texts of the 13 oral histories collected for this project are on permanent file at the CAR laboratory.

Carrying our intensive examination of the area between South Alamo and Cherry streets one step further, Shirley Mock has concentrated on a small fraction of the population in the immediate area of the Alamodome. Through numerous personal interviews, intensive research in newspaper files and other archival materials, and reference to specialized secondary writings, she has composed an intimate view of what an African-American's life was like on the east side of San Antonio during the first half of the nineteenth century. Mock also introduces numerous prominent black individuals who made contributions to the community.
Herbert Uecker has narrowed his view to the structural evolution of the project area on a block-by-block basis. He traces the developmental history of each city block and takes it from a "mesquite and scrub brush thicket" to a modern, urban manufacturing area by using various city maps, Sanborn Insurance maps, deed records, City Directories, and family histories. The information compiled in this chapter has been essential in evaluating the area in order to choose particular lots for intensive testing. This is also a valuable collection of information for use by researchers working on the history of the urban growth of San Antonio.

The final chapter of Volume I provides a synthesis of the archival results on a lot-by-lot basis. This chapter, by Kevin J. Gross and Anne A. Fox, also relates how the archival information was used to develop the strategy for the fieldwork. 


\section{Chapter 1 \\ Project Setting, Phases, and Methodology}

\section{G. Kenneth Wright}

\section{Introduction}

On March 15, 1990, the Center for Archeological Research (CAR) of The University of Texas at San Antonio (UTSA) contracted with the city of San Antonio's Multipurpose Domed Stadium Development Advisory Committee and VIA Metropolitan Transit Authority to undertake cultural resource investigations of a 17-block (65 acre) area in downtown San Antonio, Texas (Figure 1-1). The area was to be razed for construction of the Alamodome and its associated access and parking.
From mid-March to early July of 1990, and periodically thereafter, intensive archival and historical research on the entire project area was carried out by CAR. Architectural recording and assessment of all standing buildings was done by Andrew Perez and Associates. Thirteen oral history interviews with residents, former residents, and officers and employees of business establishments in the general area were recorded and transcribed by E. L. Fly and Associates. This was the first phase of a multiple-phase project that also included archaeological test excavations during 1991 and 1992. The project was

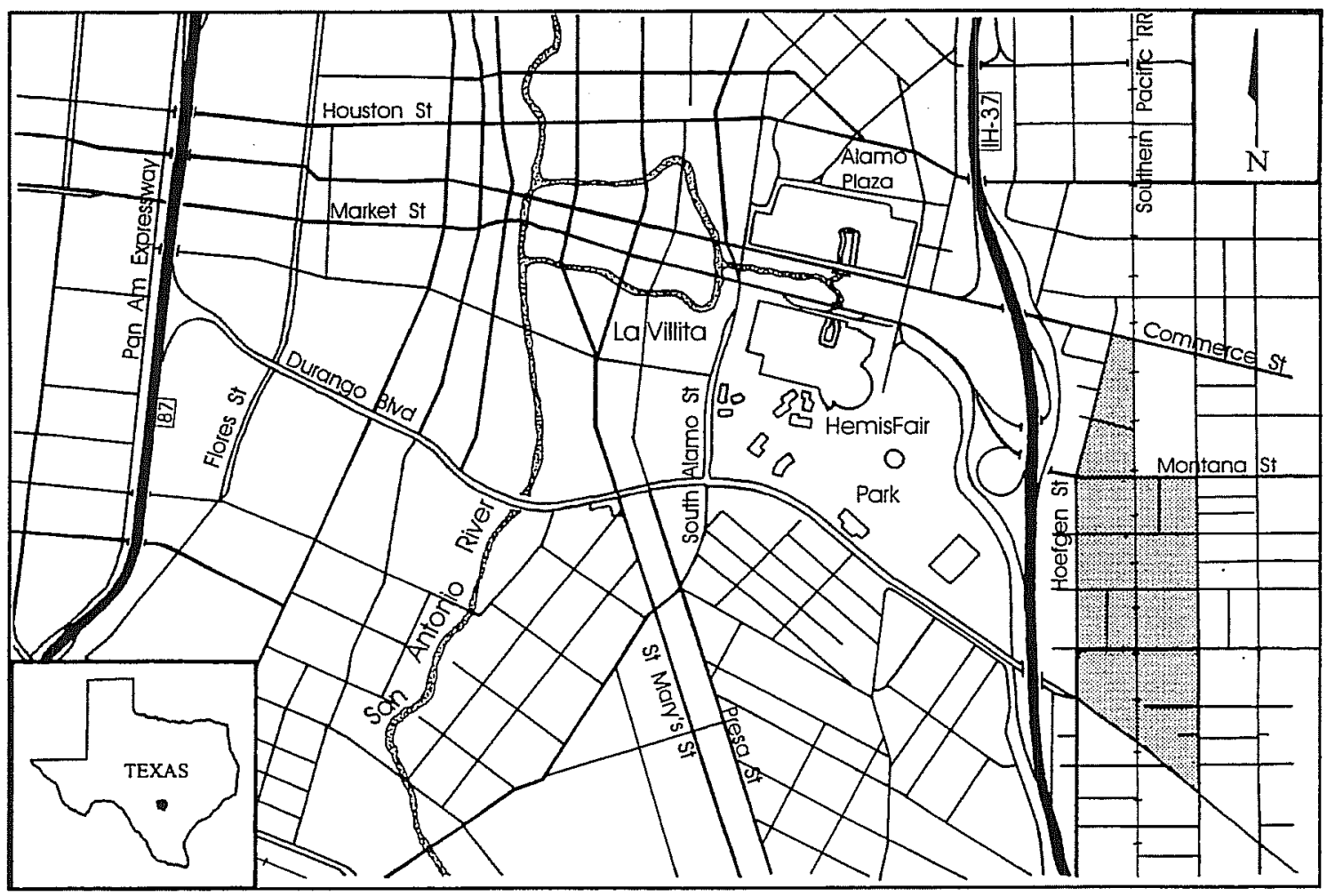

Figure 1-1. Location of the Alamodome Project (shaded area). 
conducted under Texas Antiquities Committee permit numbers 900,930 , and 982 . The artifacts recovered from the investigations were then processed, cataloged, and analyzed. All artifacts, site records, and administrative records are on file at the CAR laboratory on the campus of UTSA.

\section{Environmental Setting}

The project area rests on a slight slope running downhill north to south across the area. A ridge which runs between Salado Creek to the east and the San Antonio River to the west is topped by three small hills. El Divisadero (elevation $760 \mathrm{ft}$ above mean sea level [amsl]) is located just north of $\mathrm{IH}-35$, and just south of Fort Sam Houston. Dignowitty Hill (elevation $744 \mathrm{ft}$ amsl) is just north of the city cemeteries near Lockwood Park. Harmony Hill (elevation $730 \mathrm{ft}$ amsl) is located just south of the city cemeteries near the corner of Palmetto Avenue and Martin Luther King Street. The project area lies on the western slope (facing the San Antonio River) between Dignowitty and Harmony Hills at an elevation of 650-660 ft amsl.

The soil of area is described by Collins (Volume II) as Houston Black Clay. This type, defined as a slowly permeable, calcareous clay (Taylor et al. 1991:20-21), is characteristic of upland settings. Naturally occurring flora across this zone includes larger tree species such as live oak, Texas oak, hackberry, elm, walnut, several species of acacia, and pecan (Black and McGraw 1985).

Climatic conditions are characterized by mild winters (continental influences), and hot humid summers (maritime influences). A long growing seasonaveraging 268 frost-free days per year-is typical. The average rainfall is 28 inches per year, but varies greatly on a year-to-year basis and short-term droughts of several months are common. Rainfall extremes (droughts and floods) are the major limiting climatic factors (Black and McGraw 1985). Historically, the San Antonio River flooded periodically, causing great damage and loss of life. Disastrous floods occurred in 1819 and 1865; a terrible flood in 1921 killed 50 people and destroyed three million dollars worth of property. This led to the construction of Olmos Dam above the river's headwaters to control river flooding (McLemore 1980).

\section{Project Area Background}

The study area comprises approximately 65 acres on the east side of the San Antonio River between Goliad Road and the former Alameda (now Durango and Commerce streets) (Figure 1-2). The western extremity of the project area lies approximately 1,000 varas $(2,770 \mathrm{ft})$ from the San Antonio River at its closest approach.

The area was originally part of the farmlands surrounding the Mission San Antonio de Valero (the Alamo). When the city was incorporated in 1842 by the Republic of Texas, it was given authorization to sell unimproved lands within its jurisdiction (Figure 1-3). On August 24, 1849, the San Antonio City Council authorized such sales, including the current study area (Andrew Perez and Associates 1990).

Starting in 1845 , a program of German immigration into this part of Texas was sponsored by the Society for the Protection of German Immigrants in Texas, under the leadership of Prince Carl of SolmsBraunfels. This led to the establishment of cities such as New Braunfels, Fredericksburg, and Boerne. However, directly on the route to these new communities from Indianola, the major port of immigration, was the city of San Antonio. Many of the new German immigrants viewed the land sales in San Antonio as an opportunity to become established in a city which was, in effect, the crossroads to the frontier. Many initially chose to settle in San Antonio while others moved to San Antonio after a period of residence in one or more of the other communities (Biesele 1987[1930]). One of the primary areas of settlement in San Antonio for these new German citizens was the area in and around the current HemisFair district, including the area under investigation.

Growth in the area began slowly. Between 1850 and 1860 , approximately eight residences were located within the study area (Figure 1-3). All but two were owned by German families and these were eventually acquired by Germans. By 1880 the population of the area was still small and consisted of only 15 residences that were primarily German. However, things began to change when, in 1877 , the railroad reached San Antonio and the rail line ran through the project area. 


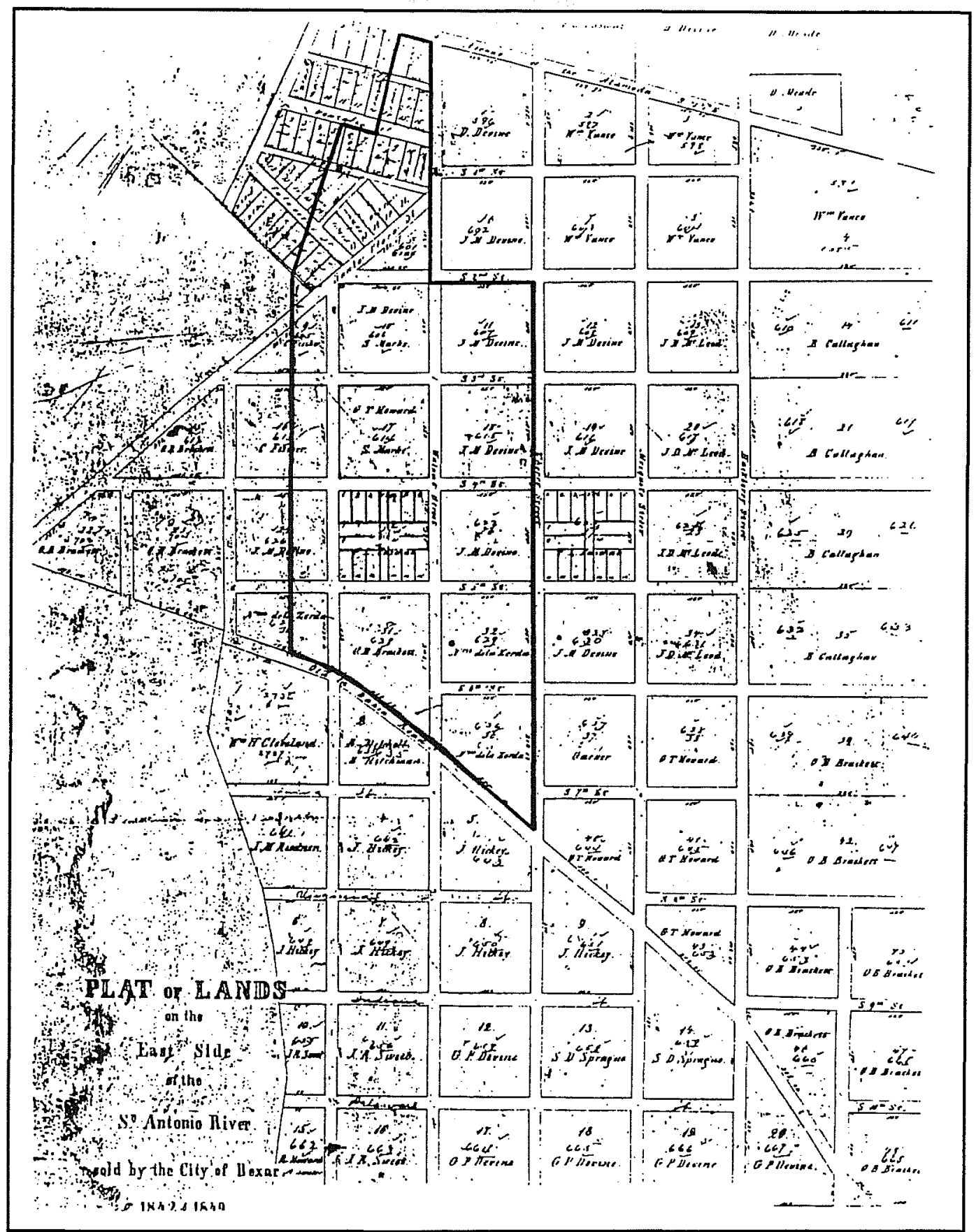

Figure 1-2. Alamodome Project area (dark lines) superimposed on the 1842 city plat.

Industries soon began to locate close to the rail line, attracting additional settlers in search of work. Between 1880 and 1890 , the area underwent a boom, growing from 15 to about 53 residences (Figure 1-3), and saw the establishment of industries such as Alamo Iron Works and Steves Lumber Yard.
With the rise in population came increased ethnic diversity. As new industries and commercial enterprises developed, Hispanic, African-American, Polish, and other ethnic groups settled in the neighborhood. However, the general nature of the neighborhood remained primarily German until after the turn of the century. 


\section{Project Phases}

The urban nature of the Alamodome Project, subcontractor concerns, a limited time frame, and budgeting elements combined to necessitate the creation of a five-phase project. It is generally understood that elements of any particular phase might be employed to some extent throughout the course of a project. For example, archival research was a continuing endeavor throughout the course of the Alamodome Project, not just within Phase I.

The phases, with their associated methodologies, are described below. More in-depth discussions of archaeological methods are presented in Volume II of the series.

\section{Phase I: Background Research}

Phase I included archival, oral history, and architectural research concerning the area within and around the project. This phase was carried out between April 15, 1990, and April $15,1991$.

Archival research was undertaken to establish when and by whom the area was first occupied, and to document how the neighborhood developed over time. We also compared and contrasted the project area's development with that of two other neighborhoods destroyed by construction activities: Rivercenter Mall (originally named Las Tiendas) and HemisFair Plaza. The effect of the arrival of the railroad on the Alamodome neighborhood was evaluated, as was the impact of the introduction of industry into the area. The history of the Valley Ditch was reconstructed, and its effect on the area evaluated. A complete reconstruction of the ownership history of the city blocks in the project area was required, using all available resources in public and private libraries and archives in San Antonio and Austin, city hall, other city offices, and the county court house.

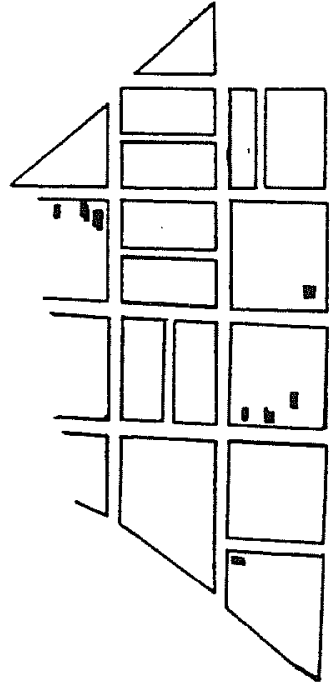

$1850-1860$

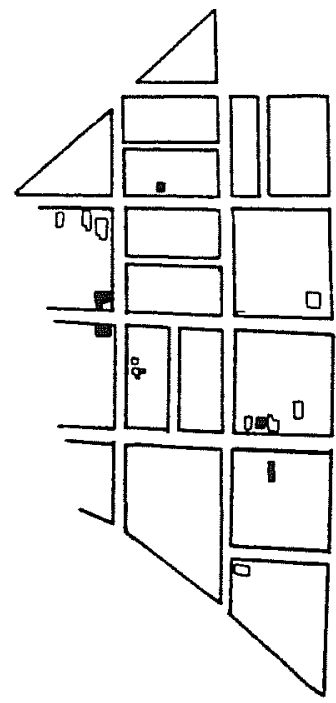

$1870-1880$

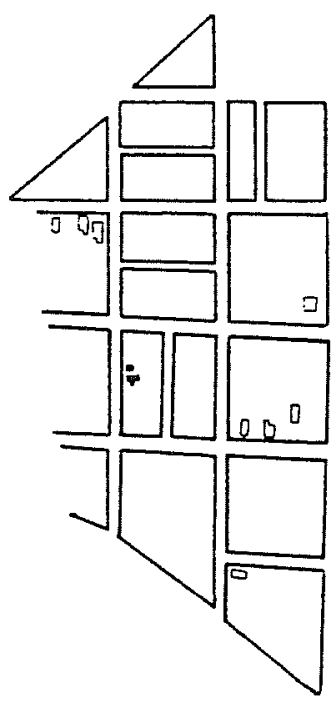

$1860-1870$

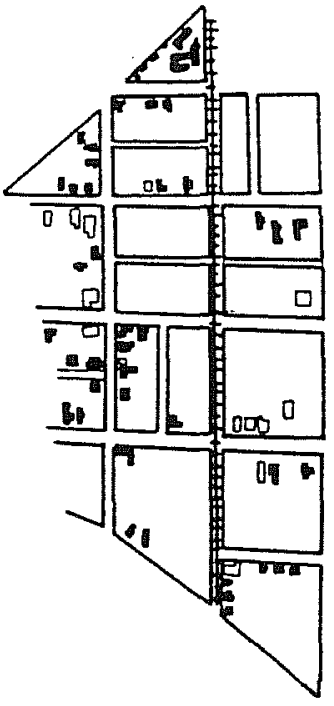

$1880-1890$
Figure 1-3. Building development in the project area, 1850-1890. Darkened buildings were built during that period. 
One of the most common reference tools used during the course of the Alamodome Project was the Sanborn fire insurance map. The Sanborn Company-a division of Real Estate Data, Inc., in Pelham, New York-has been publishing maps since 1866 . For larger cities the Sanborn Company updated its maps every two to three years, and for smaller communities every seven to 10 years. In many cases the updates would not involve the generation of a totally new map; the old map would be updated by pasting new sections over the outdated areas.

The maps were originally intended to address the needs of the fire insurance industry. With the development of better fire-fighting equipment, telephones, automobiles, and the implementation of building codes, much of the need for such maps has been eliminated. Since the fire insurance industry no longer needs Sanborn maps, the company has regeared its operations to address other interests such as real estate, urban planning, and historical research. As a result, only a handful of cities in the United States continue to be updated with new maps.

The earliest Sanborn maps for San Antonio date to 1877 and cover only the area around the central plazas. For the area investigated during the Alamodome Project, maps were available for the area around the Southern Pacific Railroad station (NCB 679) dating back to 1883; however, maps were not available for the whole area in general until 1904 . Three Sanborn maps-1904, 1911, and 1952-were available to the project for use during the course of investigations.

Although in some cases Sanborn maps made reference to a building's construction material and function, this was by no means consistent. No information pertaining to the age of structures was present other than the date of the map itself.

Deed records, builders' liens, city directories, and many other sources were available to supplement the Sanborn maps. With such a large-scale project, we were presented with an ideal opportunity to test the Sanborn maps for their accuracy. Comparisons with other sources and the archaeological record would allow for such an assessment.
The architectural documentation completed by the firm of Andrew Perez Associates (APA) includes photographic and descriptive documentation of the architecture, materials, and chronology of all standing structures in the project area. Each building's location was identified on a site plan. Buildings considered to be historically significant were described in greater detail. All buildings slated to remain in the project area were similarly recorded, with additional statements of the condition of the building and more detailed history of the structure. All required Historic American Buildings Survey (HABS) drawings were also completed by APA. The results of the APA documentation was compiled into a report which was submitted to CAR for its use in preparation of the final report (APA 1990).

The cultural history research, which included oral interviews and other supporting research, was conducted by E. L. Fly and Associates, Inc. The intent was to augment the research conducted by CAR and APA. E. L. Fly and Associates developed questionnaires, then conducted taped oral interviews with residents, business persons, and community, religious, and educational leaders from the project area. They then transcribed all interview tapes and compiled the results of the interviews into a written account of the sociocultural history of the Alamodome area (E. L. Fly and Associates 1990).

The various aspects of the archival research revealed a thorough and fascinating picture of early San Antonio. The results of the studies are presented in this volume.

\section{Phase II: Surface Reconnaissance and Archaeological Testing}

Phase II testing was designed to identify significant archaeological features present beneath the surface and to provide a large enough sample of artifacts from across the site area to constitute a valid representation of what could be expected in future planned excavation in the area. This phase, conducted between June 30 and September 30,1994, included surface surveys and test excavations across the project area. 
Five major unit types were utilized during the course of the Alamodome Project for sample collection and feature discovery and exposure: $2-\mathrm{x}-2$ - $\mathrm{ft}$ test units, 4-x-4-ft mitigation units, shovel tests, backhoe trenches, and geomorphic trenches. These unit types are detailed in Volume II of the series.

Backhoe testing was done on each block throughout the footprint and laydown areas and in other selected areas outside, in order to record the depositional history of the project area. From the data recovered, research goals were formulated for subsequent testing and mitigation. The geomorphic testing was completed at the same time, with backhoe trenches excavated to the maximum extent of the machine. Results of the geomorphic study are included in Volume II.

\section{Phase III: Demolition Monitoring and Special Mitigation of $41 B X 897$ and $41 B X 930$}

From October 1 to December 20, 1990, the Alamodome contractors removed soil within what was known as the "footprint" of the Alamodome, the actual area where the structure was to stand. This was done on such a massive scale that the entire archaeological field staff of about 10 people was devoted to the task of monitoring the soil removal. Numerous archaeological features were revealed during this course of the demolition, all of which were recorded, and in many cases "spot-mitigated" before continued demolition of the area was permitted.

Monitoring of demolition was not required until the contractor removed foundations, footings, piers, slabs, or other structural features that intruded below grade and might have disturbed buried resources. The demolition contractor was instructed to notify the archaeologists when the demolition reached the foundation level on each site. Below-grade demolition was monitored on a full-time basis, with special attention to lots with the potential to contain wells, privy pits, and other below-ground features.

One unfilled limestone well (41BX930) was discovered inside the footprint area, so special provision was made to investigate there. Another well had been discovered during Phase II just outside of the footprint area, but located on the proposed access ramp into the footprint. Special provision was also made for mitigation of this site so that demolition could proceed in a timely fashion.

\section{Phase IV: Mitigation}

Five of the 36 recorded sites were recommended for full-scale mitigation. Due to political circumstances beyond UTSA's control, only three of the five sites were actually mitigated. Also during this phase, conducted from January 15 through May 30, 1991, mitigative excavations were carried out in a large area on the south side of the project area (Runge Street). This area contained 11 small dwellings which received individual site numbers for administrative purposes, even though the strategy for excavation was to treat the entire area as a single site.

\section{Phase V: Final Mitigation of 41BX896, Laboratory Analysis, and Reporting}

Subsequent to the completion of work performed during Phase IV of the project, the Texas Antiquities Committee requested additional work at $41 \mathrm{BX} 896$ beneath the floorboards of the house which was present on the site. This work was done during the first week of Phase V (May 1 to May 8, 1992). The rest of the phase was spent in artifact processing, analysis, and preparation of the final report.

All artifacts were processed at the CAR laboratory. Standard procedure for artifact processing involved washing, air drying, labeling, and cataloging. Analysis of various artifact categories was performed; results of these studies are presented in Volume III. 


\section{References Cited}

Andrew Perez Associates (APA)

1990 Architectural Inventory and Assessment, Multi-Use Dome Stadium Site, VIA Transit Terminal Site. Manuscript on file. Center for Archaeological Research, The University of Texas at San Antonio.

Biesele, R. L.

1987[1930] The History of German Settlement in Texas, 1831-1861. McNaughton and Gunn, Ann Arbor, Michigan.

Black, S. L., and A. J. McGraw

1985 The Panther Creek Springs Site: Cultural Change and Continuity Within the Upper Salado Creek Watershed, South Central Texas. Archeological Survey Report, No. 100. Center for Archeological Research, University of Texas at San Antonio.

E. L. Fly and Associates, Inc.

1990 Oral History Interviews: Dome Project 1990. Manuscript on file. Center for Archeological Research, University of Texas at San Antonio.

McLemore, D.

1980 A Place in Time: A Pictorial View of San Antonio's Past. Express-News, San Antonio.

Taylor, F. B., R. B. Hailey, and D. L. Richmond

1991 Soil Survey of Bexar County, Texas. United States Department of Agriculture, Soil Conservation Service, Washington, D. C. 


\title{
Chapter 2 \\ The Growth of San Antonio
}

\author{
I. Waynne Cox
}

\section{The Founding of San Antonio}

Although the area of San Antonio was first encountered by the entrada (expedition) of Domingo de Terán on June 13,1691, the lush and watered valley of the river they named San Antonio de Padua remained merely a pleasant stopover point on the way to the eastern provinces that served as a buffer against intrusions of the French. The beauty and desirability of the site were again reported by the priests of the Aguira expedition on their way to reestablish the failed mission efforts of East Texas. Friars Isidro Felix de Espinosa and Antonio de San Buenventura Olivares recorded that the area "could supply not only a village, but a city, which could easily be founded here because of the good ground and the many conveniences, and because of the shallowness of said river" (Tous 1930a:5). Nothing came of their recommendations, but in 1716 the redoubtable Fray Espinosa, now accompanying Captain Diego Ramón to reestablish the East Texas effort, again reported the beauty and lushness of the location (Tous 1930b). This time the viceroy was convinced of the need for a way-station between the Rio Grande and his eastern missions, so he dispatched Governor Don Martín de Alarcón to establish a presidio in the San Antonio valley.

Alarcón, accompanied by Fray Olivares and seven families of settlers, crossed the Rio Grande on April 9, 1718 , to fulfill the viceroy's directive. Harsh arguments had arisen between the governor and the cleric before their departure, so they traveled the route in separate parties and arrived at the San Antonio River after a 16-day journey. Fray Olivares immediately explored the vicinity and established a site for his mission, San Antonio de Valero. On May 5, 1718, Alarcon unfurled the royal standard "with the requisite solemnity" and established the presidio of Bejar near the headwaters of San Pedro Springs (Hoffman 1935:49). Leaving the settlers and a small contingency of troops, he proceeded onward to the East Texas settlements and returned in January of the following year. Finding "nothing unforeseen what so ever had happened," he ordered new supplies, livestock, and munitions for the villa (Hoffman 1935: 22). In the spring of 1719, Fray Olivares relocated his mission to the east bank of the river, opposite the largest bend. In 1724 this location was virtually destroyed by a hurricane, so the mission was reestablished "two gunshots" to the north, its present location (Habig 1968:41).

The missions of East Texas again failed to prosper, the crops faltered, disease spread among the Indians, and many soldiers deserted the isolated presidios. After a French attack on Mission San Miguel de los Adaes in the summer of 1719 , the Spanish withdrew all the missionaries to Bejar where they were to await Governor Aguayo and his troops to escort them back to their stations (John 1975:224). One of the refugee priests, Fray Antonio Margil de Jesús, encountered three groups of Indians who desired mission life but were incompatible with the neophytes at Mission Valero. Fray Olivares resolved to found another mission further down the river to accommodate them. On February 23, 1720, under the authority of Captain Juan Valdéz, he established Mission San José y San Miguel de Aguayo on the east bank of the river. Mission San José was moved to the west bank prior to 1727 (Figure 2-1) (Habig 1968:27; Valdéz 1720). 


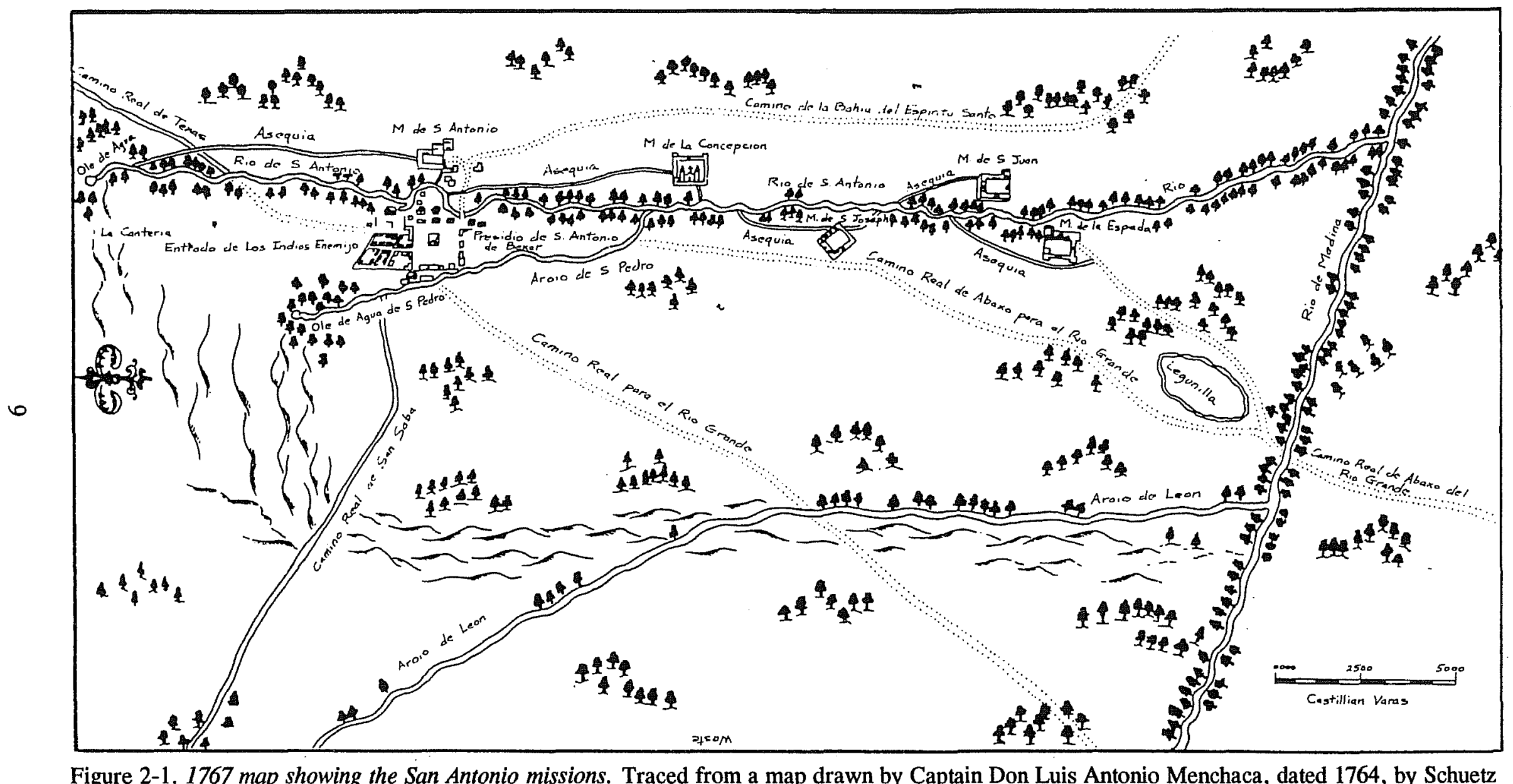

Figure 2-1. 1767 map showing the San Antonio missions. Traced from a map drawn by Captain Don Luis Antonio Menchaca, dated 1764, by Schultz (1966 :Figure 2) 
In April 1721, Governor Aguayo reached the Villa of Bejar, with a force of 500 men and 4,000 horses and other livestock, intent on reclaiming the eastern buffer zone. Accompanied by the dispossessed friars, he reestablished the missions and founded the Presidio Nuestra Señora del Pilar de los Adaes, near the Sabine River in East Texas. Upon the governor's return, he was met at the Trinity River with the disturbing news that the settlement at Bejar had been inadvertently destroyed by fire. Sixteen huts and the granary, with its store of 700 bushels of corn, had burned. Upon his arrival in January 1722, he ordered the presidio rebuilt between the river and San Pedro Creek, opposite Mission San Antonio de Valero, now present day Military Plaza (Turanza 1961:75-76).

In 1724 Brigadier Pedro de Rivera y Villalon was dispatched by the viceroy to inspect and evaluate the frontier defenses of New Spain. The tour lasted until June 1728, and covered over 8,000 miles. Among his recommendations was the reduction of the East Texas garrisons and the relocation of the three Querétaran missions to new sites on the Colorado River, near present day Austin. Viceroy Juan de Acuña, the Marqués de Casafuerte, acting on the recommendations, reduced the presidios and moved the missions in July 1730; however, the new locations were not acceptable to Fray Parades, the guardian of the college. The missions were again moved, but now to the San Antonio River basin, on March 5, 1731. Nuestra Señora de la Purísima Concepción de los Hainai became Nuestra Señora de la Purísima Concepción de Acuña, and was located between San Antonio de Valero and the new site of San Jose y San Miguel. San José de los Nazonis, now San Juan Capistrano, and San Francisco de los Neches, now San Francisco de Espada, were assigned lands further to the south (Figure 2-1).

Another recommendation of Brigadier Rivera was that the frontier be settled with stable families, believing that "one permanent Spanish family would do more to hold the country than a hundred soldiers" (Chabot 1937:141). The Spanish King, Philip V, turned to the Canary Islands to provide the immigrant families for New Spain. The Canaries, so named for the wild dogs encountered by the first explorers, had been discovered in antiquity, but were "lost" until re-discovery by the Portuguese in 1341. The Spanish conquest, begun in 1402 by Juan de Bethencourt, was completed in 1496. The seven Canary Islands form an archipelago off the northwest coast of Africa. Together they consists of 2,807 square miles, much of which is mountainous and arid. Although they served as a valuable departure point for sea traffic to the New World, the islands had difficulty supporting their growing population. The king offered royal passage to the frontier, free land, and maintenance for one year, which is an irresistible proposal to many families trapped in poverty.

As an additional incentive for settlers, the king awarded the rank of hidalgo to those settling the new frontier. The title, derived from "Hijos de Algos" (literally "sons of something") denoted the lowest rank of Spanish nobility. This honor was bestowed to instill a sense of dignity to compensate for the hard life the settlers were to face; however, the recipients perceived it as removing them from the non-aristocratic working class-an unrealistic attitude for farmers on the extreme fringe of the Spanish empire.

\section{The Canary Islanders}

On March 9, 1731, fifty-six Islanders arrived at the presidio to form the nucleus of the Villa of San Fernando de Bexar, the first civil settlement of Texas. Viceroy Casafuerte had ordered that the newcomers be greeted and housed in the presidio until the villa was established a "gunshot's distance . . . to the west of the presidio" (Aviles 1732:1). The captain of the presidio, Juan Antonio Pérez de Alamazán, delayed the laying out of the villa until after the planting season, selecting "land subject to irrigation" (Aviles 1732:1) as temporary fields for the Islanders.

On July 2, 1732, Captain Alamazán called the families together, having each bring two cart loads of stone and 10 stakes, to begin the survey of the town. The site selected by Casafuerte, to the west of the presidio, was deemed unsuitable due to the difficulty of establishing irrigation; therefore, the captain altered the plan to found the settlement to the east of the presidio. This alternative required that the site for the church be reoriented to face the east. From the point designated for the church, Casafuerte laid out a plaza 200 varas $(555.5 \mathrm{ft})$ in length and $1331 / 3$ varas $(370.37 \mathrm{ft})$ in width, which allowed for streets of $131 / 2$ varas $(37 \mathrm{ft})$. During the next two days, he laid out a cruciform 
townsite to the cardinal directions from the church. On July 5 , he measured 1,093 varas $(3,035.3 \mathrm{ft})$ in all four directions to establish a square about the cruciform of 2,186 varas $(6,070.5 \mathrm{ft})$, oriented toward the northeast and southwest, for pasture and grazing lands. The original decree dictated a third unit around the pastures of 2,180 varas $(6,055.38 \mathrm{ft})$ to be common lands (ejidos), which Captain Alamazán began by measuring toward the northeast and northwest. However, as the captain noted,

it was not possible to lay off the lands for commons to the east because with the first measurement of the plot for the town, the banks of the San Antonio River were reached-and this is to serve as the division and boundary between this settlement and the missions, especially that of San Antonio de Valero which is separated from the presidio by the river alone [de Alamazin $1731]$.

He then added the unsurveyed dimensions to the remaining measures to enclose the allotted grant. The captain described the newly constructed plat:

to the northeast, from the head of the principal springs at the head of the San Antonio River in a straight line to the spot called Arroyo de Norillo; from this point along the quadrilateral-though an imperfect one-to the west to a point called Real de Nicolás Hernández, which is slightly to the northwest; and, turning south along the quadrilateral and passing across Llano de Leorn and the spot called El Real de Lagunilla which is to the right of the point called Jacalitos; thence turning to the northeast, straight toward the point called $\mathrm{El}$ Paso de Nogalitos, which is the point where the final angle of the quadrilateral is closed [de Alamazán 1731:1-24].

The final act to establish the limits of the villa of San Fernando was the drawing of lots for the farm plots of the Islanders. Alamazan had selected the fertile area to the south of the villa between the river and the creek down to the confluence of the streams. Each family was consigned a plot sufficient to plant its crops, the four single men being considered as two families. As previously noted by Celiz, the banks of the two streams were deep enough in this area to make irrigation difficult; therefore, an acequia was envisioned directly from San Pedro Springs proceeding southward between the water courses to return to the river just prior to the confluence. This design presented two distinct advantages: first, it could service the presidio and the villa, as well as the Islanders' fields; secondly, by following the high ground between the two water courses, it could irrigate lands on both sides, in contrast to the other acequias which only watered the lands toward the river. Just when the task was begun and completed is not recorded; but it is logical to assume that construction was initiated soon after assignment of the land. On January 11,1734 , by order of the viceroy, the lands were resurveyed and official title was granted to the Islanders. Excess land was also granted to eight other citizens of the villa (Leal 1986).

In 1741 Tomás Felipe Winthuysen, a civilian, was appointed governor of Texas and the new Philippines. Three years later, at the request of the viceroy, he filed a full report on the entire area under his jurisdiction. He spoke well of the San Antonio missions, in contrast to his opinion of La Bahra and the East Texas establishments. He reported that the five missions had a total of 1,300 Indian "families"undoubtedly an exaggerated number-under the charge of nine priests (Winthuysen, T. F., 1744, "Winthuysen to the Viceroy, August 19," Bexar Archives Translations [BAT], Bexar County Courthouse, San Antonio, Texas, reel 3, 15:56-68). As to the presidio, he described it as "crudely shaped houses" forming a square plaza without walls or a stockade, leaving it open to theft from the Apaches (Winthuysen 1744, BAT, reel 3, 15:56-58). He attributes this not to a lack of stone, for there are fine quarries in the area, but to the difficulty of obtaining lumber which had to be procured from the area "encroached upon by the enemy" (Winthuysen 1744, BAT, reel 3, 15:56-58). He dismissed the villa with a single statement, "it is not at all progressive, since its settlers are more given to prejudice than progress" (Winthuysen 1744, BAT, reel 3, 15:56-58).

In 1745 Fray Ortiz inspected the missions and reported considerable progress toward permanent construction. The stone church at Concepcion was half completed and an adobe building was serving as the temporary church. The Indian pueblos were still thatch, but were enclosed by a stone and adobe wall. Three stone houses for the soldiers, a stone granary, and a two- 
story structure for the priests were in place. At San Francisco de Espada, fabrication of the stone church had begun, with the sacristy complete and serving as the church. The Indian houses were thatch, but the missionaries had a stone building with two cells, an office, and a storeroom for grain. At Mission San Antonio de Valero, the stone church was under construction and a two-story stone convent had been completed (Ortiz 1745). On his second visit, 11 years later, Ortiz reported that the church of Concepcion was complete, the dedication having taken place on December 8, 1755. He further noted that the acequia flowed through the mission square and watered the fields and orchards outside the walls. The stone church at Valero had been completed, but poor construction had caused the tower and roof to collapse, and repairs were underway (Ortiz 1756).

In 1756 the major powers of Europe became embroiled in what was to become known as the Seven Years' War, the first war to involve the whole continent. The results of that conflict were to have major impacts throughout Europe, as well as in Asia and North America. When the war ended with the Treaty of Paris, on February 10, 1763, Great Britain emerged as the undisputed leader in overseas colonial power, having gained control of France's empire in India as well as most of the French possessions in North America. Spain was forced to relinquish Florida to the English, but was compensated, in a secret treaty with her ally, with the French territories to the west. The major threat to the Spanish frontier shifted from the French to the British and the increasingly hostile border tribes. Texas ceased to be the outpost against the French threat, the purpose it had held since its founding, and Spain was required to reconcile its defenses to fortify Louisiana and California and strengthen the frontier against the Indians (Bolton 1915:102-104).

King Carlos III appointed the Marqués de Rubí (Cayetano María Pignatelli Rubí Corbera y Saint Clement) the formidable task of investigating and evaluating the defenses of this vast borderland. Rubí began his inspection in the far northwest in March 1766, and reported his findings to the king in April 1768. Rubi found little good to report about the East Texas missions and presidios: the garrisons were in ruins and undermanned, and the missions had been unable to attract or retain Indian populations ( $\mathrm{La}$ Fora
1958:160). The marqués determined that Spain was attempting to spread too little over too much territory, and a more realistic evaluation of her true dominion was necessary. He recommended a cordon of 15 strongholds spaced at regular intervals between $\mathrm{La}$ Bahía del Espiritu Santo to the Gulf of California, with Bexar and Santa Fé as outposts (Bolton 1905: 67-69). These recommendations resulted in a Royal Order, on September 10,1772, to implement Rubi's new plan of defense.

The order reached the governor of Texas, the Baron de Ripperdá, in May of the following year. Upon his arrival in East Texas, he encountered a population of more than 500 protesting citizens, whom it was his duty to expel. He ordered the evacuation to begin in five days but, faced with protest, he allowed extra time and the exodus from Las Adaes began on March 25. Forced to abandon their ripening crops and much of their livestock, the inhabitants suffered many hardships on the journey, and arrived in San Antonio on September 26 (Bolton 1915:113-115). Upon their arrival, Ripperdá ordered them to select any lands they desired-providing there was no interference with the lands already assigned to the settlers or Indians-and granted them permission to construct an acequia, at their own expense, from the San Antonio River. They immediately lodged a protest, stating there was not enough land for settlement without encroaching upon the rights of others and their poverty did not allow them to construct the proposed acequia; they therefore requested permission to return to the eastern frontier. The request to return was refused, but in 1774 they were allowed to establish a new settlement on the Trinity River, Nuestra Señora del Pilar de Bucareli (Bolton 1905:90-106). While the majority of the refugees did relocate, some of the settlers remained in San Antonio adding a new element-the adaesanos-to the community.

\section{Secularization of the Missions}

By the last two decades of the eighteenth century, the missions were past their fluorescence and were in decline. Expulsion of the Jesuits from the New World in 1767 created a shortage of priests for missionary efforts. In 1772 the four Querétaran missions of San Antonio were transferred to the College of Zacatecas. Fray Morfi reported that the population at San Antonio 
de Valero had dropped to the point that there were hardly enough Indians to tend the fields. The adaesaños who had settled near the mission requested that the unused land be distributed among them, because they had no land upon which to raise their crops (Chabot 1932:60).

In 1790 the College of Zacatecas dispatched Fray Manuel Silva, commissary and prefect of missions, to evaluate the state of their efforts among the Indians. Silva recommended that San Antonio de Valero be secularized, and that the other four missions be reduced to only two. On January 9, 1793, the viceroy issued a decree implementing the recommendations and, on February 23, Governor Manuel Muñoz published a proclamation putting the decree into effect. On April 12, the farmlands of Mission Valero were surveyed and plots given to the 14 family heads and unmarried adults of the mission. For their efforts, the surveyor and his assistant, Pedro Huizar and Vincente Amador, were awarded similar tracts (Habig 1968:66-67). The plots awarded to the Indians were in the area which became known as the Labor de los Mochos, roughly delineated by present day Durango Boulevard on the north, Presa Street on the east, the San Antonio River to the west, and the St. Mary's Street overpass to the south (Spanish Archives, Bexar County Courthouse, San Antonio, Texas, 2:60). This contains the area now recognized as the King William Historic District.

In October 1790 , the adaesaños finally received the land for which they had been petitioning some 20 years. They were granted the remaining mission lands to the east. These lands, the Labors de Afuera, were distributed to the 40 heads of families "of converted Adaes Indians and others," as well as four residents of the villa (Bexar County Archives, Mission Records 2, Spanish Archives Volume 3:305-315). This area is now generally enclosed by Commerce Street to the north, Interstate 37 to the east, the St. Mary's Street overpass to the south, and South Presa Street to the west.

As secularization of the missions began, the dynamic forces in motion in Europe spilled over into the western hemisphere. France was in revolution and at war with England, Austria, Prussia, and Spain. The ineffectual Spanish king Charles IV was compelled to seek peace in 1795, falling under French control and becoming a pawn against England. As the century came to a close, France, with its ring of satellite republics, had emerged as a major power bloc in western Europe; Napoleon Bonaparte, heir of the revolution, was a menace to the balance of power and peace of all Europe. To further threaten Spanish control, the seeds of revolution and liberalism begin to take root throughout her remaining empire.

In December 1802, the presidio garrison at Bexar was augmented by the Compania Volante de San Carlos del Alamo de Parras, the Light Cavalry Company from the town of Alamo de Parras, Coahuila. The governor, Nemesio Salcedo, assigned the soldiers to quarters in the now-abandoned Mission San Antonio de Valero (letter, "Salcedo to Viceroy, December 29," Bexar Archives, Bexar County Courthouse, Reel 30, frames 947-949); from this occupation the old mission received its more familiar name, the Alamo. In 1805 the first hospital was established there to care for the number of patients "which the change of climate has caused in the troops from other parts of the country" (Nixon 1936:16).

In 1803 Napoleon, seeing his hope for an American empire fading and strapped by debt from his Asia and European campaigns, sold the Louisiana territory to the United States for $\$ 15,000,000$. This focused Spain's Anglophobia on her new neighbor. These fears appeared to materialize when, in 1807 , Zebulon Montgomery Pike, on his expedition to explore the headwaters of the Arkansas and Red rivers, allegedly lost his way and entered Spanish territory (Couse 1965). Captured by Spanish authorities, he was taken to General Manuel María Salcedo; while being escorted back to American territory, he passed through San Antonio. He reported, "it contains perhaps 2,000 souls, most of whom reside in miserable mud-wall houses, covered with thatched grass roofs" (Couse 1965:783-784).

In 1808 Charles IV abdicated in favor of his son, Ferdinand VII, but Napoleon moved his army into Spain and placed his brother, Joseph, on the throne. This attempt to seize total control created a popular uprising and the formation of guerrilla forces who, joined by the English, drove France from the peninsula five years later. 


\section{The Rise of Independence}

During this period of unrest, the seeds of revolution took root in México, not in the capital, but in a remote mining district. Fray Miguel Hidalgo y Costilla, at the head of an army of Indians, mestizos, and a few Creoles, declared for independence on September 16, 1810. In January of the following year, the revolution spread to San Antonio. Juan Bautista Casas, backed by the presidial garrison, placed himself as head of the government and declared for Hidalgo. His despotic and disorderly administration was overthrown on March 2, and he surrendered to the opposing forces. Casas was sent to México, tried and beheaded, and his head was returned to San Antonio to be displayed on a pole as a warning to other rebels. Fray Hidalgo's army was routed the same month that Casas took power, and his execution followed in August of the same year (Faulk 1964:134; Webb 1952 Vol. I:305).

But the rising wave of independence did not die with Hidalgo, and made Texas appear ripe for the filibustering ambitions within the United States. In August 1812, José Bernardo Maximiliano Gutiérrez de Lara, a follower of Hidalgo, united with Lieutenant Augustus W. Magee and crossed the Sabine River with 130 men and captured Nacogdoches. Recruiting Mexican, Indian, and American supporters, they occupied La Bahía on November 7, where they were placed under siege by Governor Manuel Salcedo. Upon the death of Magee on February 6, 1813, Samuel Kemper assumed command. The following month Kemper, with about 800 men, marched toward the Spanish seat of power. San Antonio surrendered unconditionally on April 1, and three days later 14 loyalist officers, including Salcedo, were executed. The following August 18, General Joaquín de Arredondo, with some 4,000 men, met and routed the insurgents south of the Medina River. Arredondo's retribution was swift and bloody: in addition to the 600 slain on the field of battle, he imprisoned most of the population of the city. In all, 327 rebels were executed in Bexar alone. The retaliation left the town a shambles, the property of the citizens confiscated, and the majority of the men either dead or having fled the country (Cox 1990:1-9).

This depletion of the manpower and resources of the province was to have a far-reaching effect that would influence both the political course of the government and the economy for more than two decades. The most immediate ramification was on the basic agricultural practices upon which the area was entirely dependant. Without the male population, no labor was available to maintain the acequia systems and plant the crops, resulting in extreme hardship and shortages of food. The depletion of manpower also intensified the everpresent problem of harassment from the Indians. Without men to guard the cattle and escort the workers to the fields, Indian attacks became bolder and more frequent. The problem is graphically clear in a petition by the citizens to the town council for assistance. Don Vincente Gortari calls attention to

the extreme poverty of the people; the constant burdens to which the small number of the citizens which the town has are exposed; and the urgency in which they find themselves today of coming to the aid of their enterprises; cleaning of ditches and other tasks as imperative as they are indispensable for obtaining the harvest upon which the subsistence of the public depends [City Council Minutes (CCM), Spanish Minute Book (SMB) 1:54].

As if the citizens of the villa were not beset by enough troubles, a natural calamity fell upon them at five o'clock on the morning of July 5,1819 . Governor Antonio Martinez reported to the viceroy,

suddenly without the least chance of averting disaster, the torrent of water left its channel and spread over the town with a force beyond imagination; houses were washed from their foundations with the families inside; they were seen to revolve in whirlpools formed by the rushing waters; then lashed by the many heavy logs that the river brought down with fury and violence, said houses began to disappear, leaving only fragments afloat to indicate the disaster that overtook them [Quirarte 1983:34].

Hardly a house remained to the west of the river. The wooden houses were all washed away, and the stone houses had their interior adobe walls demolished.

With the frontier in ruins, the viceroy's inspector could offer no other option to repopulate the villa than to restore all confiscated properties to "the original and legitimate owners" to encourage their return (Hatcher 
1919:64). In December 1820, a bankrupt lead miner from Missouri, Moses Austin, arrived in San Antonio with a partial solution to the lack of settlers in Texas: a request for authority to begin a colony of Anglo-American settlers. His petition was granted on January 17,1821 , allowing him the right to settle 300 families on 200,000 acres. After his death in June of that year, his son, Stephen Fuller Austin, began work to carry the project forward into reality.

However, events in México were moving toward a dynamic change in Spanish control. The revolutionists continued their struggle on several fronts, until Vicente Guerrero joined with Agustín de Iturbide, a mestizo officer, and reached an agreement of purpose, the Plan of Iguala, that turned the tide for independence. Iturbide entered the capital on September 27, 1821, and Mexico became an independent nation. When Stephen F. Austin arrived with his first colonists, in December of that year, he found that the new government did not recognize his grant from the old government. He immediately rushed to México City and succeeded in getting the congress to complete a law effectively re-establishing the empresario program. Mexican independence was a reality, but the transition did not bring tranquility. Less than a year after Iturbide's victory over the Spanish Royalists, he instigated a revolt and proclaimed himself Emperor Augustine I of México. He held power less than a year before being overthrown and exiled. The monarchy was replaced by the Constitution of 1824 , influenced by the United States Constitution and European liberalism. The Constitution of 1824 merged the provinces of Texas and Coahuila into one state, with its capital in Saltillo, resulting in a loss of prestige for San Antonio. Texas became a separate "department" with San Antonio de Bejar as its capital.

Since the law was annulled when Iturbide abdicated, Stephen F. Austin traveled to México City again and induced the government to grant him a new contract allowing him to introduce 300 families into Texas (Webb 1952 Vol. I:80-82). Other empresarios soon followed, producing a steady flow of immigrants, primarily into the rich bottom lands of East Texas. This influx of new settlers had little effect on the population of San Antonio, which now numbered only 1,625 .
Yet the conflict between the federalists and the centralists continued to fracture the government, aggravated by foreign intervention. In 1829 Spain invaded México in an attempt to regain the country, only to be repelled by a young officer, Antonio Lopez de Santa Anna Pérez de Lebrón. The fame from this victory would gain him the popularity to propel Santa Anna to the future presidency of México.

\section{Strife in the North}

The heavy-handed policies of the United States minister to México, Joel Poinsett, infuriated the Mexican government and aroused new hatred and fear of the North Americans. Anastasio Bustamante, a reactionary tyrant, seized power and placed Texas under the control of Manuel Mier y Terán, an avowed critic of North American colonization. Terán moved to garrison Texas with troops, an action which angered and threatened the new colonists. In May 1832, Captain Juan Bradburn declared 10 leagues of the coast under martial law and arrested several citizens, including a young firebrand named William B. Travis. Rebellion broke out among the Anglo-Texans, who moved to attack Bradburn's headquarters at Anáhuac. The rebels captured Fort Velasco, at the mouth of the Brazos River, rallying their forces with cries for the return of the Constitution of 1824 and the hero of Tampico: Santa Anna. Total rebellion was averted only by the diplomatic effort of Stephen F. Austin and the continuing chaos within the government (Fehrenbach 1983:174-180).

In October 1833, the ayuntamiento (city council) of San Antonio received a communication from Stephen F. Austin inviting it to provide its support to his plan for organizing separate statehood for Texas, "and carrying the matter to extremes, even if it were without the obligation of securing the consent of the General Congress" (CCM SMB 2:309). The council was shocked, but "felt that Señor Austin should be formally answered, making clear to him the disapproval with which his proposal had been viewed" (CCM SMB 2:309).

In June 1834, President Farias was ousted and Santa Anna took control of the government. The latter was fully entrenched in power by the next year. The state of Zacatecas rose in revolution and was brutally 
suppressed by Santa Anna, using methods he had learned as a lieutenant under Arredondo. In April he dispatched an army, under the command of his brother-in-law General Martín Perfecto de Cós, to put down a minor civil war in Coahuila. Cós then moved north to reinforce the garrisons in Texas. Santa Anna officially revoked the liberal Constitution of 1824 shortly thereafter. In September, Stephen F. Austin returned to Texas after 18 months of prison in México, now convinced that the differences between the Texas colony and the new government were irreconcilable. The stage was thus set for a full revolution.

The revolt began with shots fired October 1, 1835, at Gonzales, and soon the "Army of the People" under Stephen F. Austin's command was on the march to San Antonio to place General Cós under siege. Cós prepared for battle by employing his troops to fortify defensive positions about the villa. He constructed strong cannon positions around the plazas and began to convert the old Mission Valero into a fortification. One of the alterations that Cos effected at the Alamo was to divert the branch of the acequia flowing through the compound to outside the quarters that comprised the western wall. The primary purpose of this diversion was probably to supply the earth required to construct the ramp and gun platforms erected on the interior of the chapel and at the southwest corner of the compound.

Despite victories achieved in skirmishes, such as the battle of Concepción and the "grass fight," the siege stagnated and almost dissolved. Then on December 4, a group of volunteers under Colonel Ben Milam rallied to assault the city. They took up a position at the Molino Blanco, the old mill on the first return channel of the Upper Labor acequia, and attacked the city from the north in house-to-house combat. General Cós capitulated to the Texans on December 10 and was paroled to withdraw his troops south of the Rio Grande. The humiliating defeat of his brother-in-law angered Santa Anna into a fury that drove him and his army into Texas with a speed that caught his enemy by surprise. When the Mexican army arrived on February 23,1836 , the Texans were forced into a hurried withdrawal behind the wall of the makeshift fortress of the Alamo.

Considerable speculation has taken place as to who was responsible for the fortification behind which the
Texans fought. While the engineer, Green Jameson, proposed elaborate modifications to the defenses stating that the previous attempts had "shown imbecility and want of skill," it is unlikely that few changes were completed by the time of the arrival of the Mexican army (Lord 1961:86). Samuel Maverick, a captive prior to the Battle of Bexar, reported: "during the month of November ' 35 with great labor, Cós for the first time turned the Alamo into a fort. He threw down the arches of the Church which now lie imbedded with the earth in order to make an inclined plane to haul cannon on top the Church" (Green 1921:134).

One misconception that is frequently seen in later maps and reconstructions of the Alamo is that a ditch connected the two branches of the acequia along the south wall, in effect forming a shallow moat around the entire fortification. This would have served little purpose, and has been disproved by recent archaeological investigations (Fox 1992:74). A trench, approximately three feet deep and four feet wide, was found to exist from the lunet (defensive ditch) that protected the main gate and extended along the south face of the palisade wall, but gave no evidence of deposition of silt or signs of erosion by water flow. This ditch was, in fact, a feature of the fortification of the palisade, providing earth for strengthening the vertical timbers and forming a glacis (slope) on the exterior (Viele 1861). Despite all the modifications made, the structure remained a poor fortress, lacking redoubts (projecting gun positions) to provide flanking fire.

After 13 days of siege, the Alamo fell in a concentrated assault on the morning of March 6, 1836, and Santa Anna achieved what proved to be a hollow victory. After sweeping across Texas and driving Sam Houston's army to the edge of the territory, he was caught unprepared by the Texans at San Jacinto, defeated and captured in a battle that lasted less than an hour. In a turn of events that seem to defy all odds, the Republic of Texas was born.

\section{The Republic of Texas}

Apparently with little prior planning, Texans found themselves in possession of an independent, but generally unrecognized, republic. Following the Battle 
of San Jacinto, David G. Burnet set in motion the machinery for a constitutional government. In September 1836, elections were held and Sam Houston was inaugurated as first president of the Republic. The units of local government, the ayuntamientos, were organized into county governments.

On September 23, 1837, the new city council of San Antonio, Bexar County, convened and elected John W. Smith as mayor. Smith, a participant in the siege of Bexar and the battles of the Alamo and San Jacinto, was married to a descendant of the Canary Islanders and had been a resident of San Antonio since 1830. The other council members were all natives of Bexar County (CCM A:1-6). The councilors agreed that the city would observe all ordinances of the prior government until new ones were passed. In December 1837, the legislature of the Republic passed an "act incorporating the city of San Antonio and other towns therein named" (Laws of the Republic of Texas [LRT], Law Library, Bexar County Courthouse, San Antonio, Texas, December 4, 1937). In the act, the citizens of San Antonio were "declared a body politic and corporate," and as such were authorized to "exercise lawful jurisdiction" over "all that tract of land originally granted to and composing said city with its precincts" (LRT, December 4, 1937). Section eight of the act further empowered the corporation to "sell and alienate such public lots or parcels of land as may lie within their jurisdiction" (LRT, December 14, 1837).

Almost immediately the council began to investigate how to avail themselves of this asset. In July 1838 they appointed a committee to "lay off a certain portion of lots for public sale" and had a plan of the "ejidos [sic] of the city" platted for public inspection (CCM A:22). They further passed a resolution declaring "all surveys which any surveyor may have made or may make within the limits of the corporation shall be null and of no effect" (CCM A:22).

In October 1841, the council agreed that a permanent bridge should be erected across the San Antonio River, and a site at the Commerce Street crossing near the Alamo was selected. A contract to construct the bridge was issued to Roderick F. Higginbotham on October 14. In order to finance the project, the mayor was authorized to collect "monies" due for the use of the corporation's one-fifth share of the irrigation waters of the acequias that had been used by those irrigating the land. Further added was the tax of two reales per annum for each dula (or day of water) as authorized by the legislature of Coahuila y Texas, number 198, of May 1, 1832 (CCM A:72).

The town, like the Republic, was without a strong financial base and was pressed to find means of raising revenue without direct taxation, an idea totally repugnant to those on the frontier. The most expedient avenue open to them appeared to be provided by the act of incorporation passed by the Republic which allowed any city to sell unclaimed public land for the benefit of the public treasury. With this in mind, the council charged the city surveyor to delineate the boundaries and plat the public lands (CCM A:74). A problem of definition immediately arose, just how much public land did the city control? City officials were well aware that the original grant from the King of Spain called for eight leagues, but this grant had not been registered and had been lost from the public records. Under the Mexican period, the legislature of Coahuila y Texas had allowed a two-league grant to the city, which officials had seen little reason to contest. These differences in the size of the public lands under control of the city would plague the council, and the courts, for many years.

Although Texas considered itself a republic, Mexico refused to recognize her independence and a formal state of war continued; however, unsettled conditions within Mexico prevented any overt action until 1842 . On March 5, General Rafael Vásquez, with 700 Mexican soldiers, arrived in San Antonio. The Texan force was too small to hold the town and withdrew to Walnut Springs (present-day Seguin). Vásquez raised the Mexican flag over the town and declared Texas still under Mexican law; his show of force completed, he withdrew two days later beyond the Rio Grande. The reported friendship between Vásquez and Juan Seguin, the mayor of San Antonio, increased suspicions concerning the latter's loyalty, forcing Seguin to resign on April 18 (CCM A:73). John Smith was again selected to hold the position, but this time a sworn deposition to support the constitution of the Republic was required (CCM A:79).

On August 23, 1842, Mayor Smith presented to the council "the plan or plot as returned by the surveyor" (CCM A:89). The city collector, James $L$. Trueheart, then rendered his report of the sale to five 
individuals, which produced $\$ 276.00$ in revenue. Of this sum, only one-half had been in cash and the remaining money was to be paid in notes due over a five-year period (CCM A:89-92). At this point the mayor filed an official protest against these sales based on the fact that the lots had been sold to produce revenue toward the construction of a bridge at the Alameda (Commerce Street). He contended that the law chartering the city and providing for the sale of public land specified that such sales were "to be appropriated to the erection and repairs of a courthouse, jail, and other public edifices as may be deemed most fit, and to the erection and endowment of a public school" (CCM A:93). He, therefore, argued that repairs to roads and bridges were to be funded under section six which specified they were to be accomplished by the "levy of equitable and moderate taxes" (CCM A:93). The legality of the plat of public lands was also questioned by persons who had settled on various portions of the property: they contended that the plat was based upon an unrecognized eight league, and the Mexican two league was the only legal limits to the corporate limits. They filed suit in district court against the city's sale of lands.

In September 1842, General Adrian Woll, a French soldier of fortune and friend of Santa Anna, returned with a larger force and again captured the city. This time the Texans offered resistance and Woll was forced to withdraw; he had, however, found the District Court in session and took with him 67 prisoners, including all the Anglo males in the town. This uneasy state of affairs was finally settled with a truce with Mexico, which established an armistice-but not peace-on June 14, 1843.

\section{Statehood}

This unsettled state of the frontier had discouraged any appreciable Anglo settlement in San Antonio; but early in 1844 , a new wave of immigration began that was to have a far-reaching effect on the ethnic make-up of the city. As early as 1842 , the Republic had granted Henri Castro a contract to settle a colony on the Medina River west of San Antonio. After many vexing delays, Castro departed San Antonio on September 1, 1844, with his first 35 French colonists, primarily recruited from Alsace. The colony eventually grew to a total of 2,134 settlers. The same year, immigrants from
Germany landed on the Texas coast to form the colony of Prince Solms-Braunfels. These immigrants settled in New Braunfels and the hill country near the Pedernales River; however, many grew disenchanted with frontier life and relocated to San Antonio.

During its entire existence, one of the primary goals of the government was to achieve annexation to the United States. Political factions and fear of adding to the power of the slave-holding south made this an unpopular issue until 1845 when, with the election of James Polk and the support of the western expansionist, a bill was passed in Congress offering annexation. On October 13, Texas adopted a new constitution and approved the offer of the United States. On February 19, 1846, Anson Jones struck the colors of the Republic and Texas became a state.

The various suits against the sale of the public lands reached the District Court of Bexar County during the September 1845 term, and the judge ordered that a new survey of the lands claimed by the city be accomplished. John James was authorized to perform the difficult task of re-establishing the eight-league grant, yet the last year the grant was known to have been in the archives was 1834. James was able to accomplish this task with the use of testimony from the oldest citizens and their memory of the location of the ancient boundary markers.

James began his survey at "an old stone dam on the Concepcion ditch . . . this place being pointed out to me . . . by Rafael Herrera and Manuel Cadena" (Corner 1890:39). He then carried the survey eastward to the "Paso Hondo on Salado (Creek)," which was indicated by the same informants, then located the next marker to the northwest on the hill known as "Lomita Divisidera" (Corner 1890:39), the city's high point (now occupied by Fort Sam Houston). The survey then proceeded to the next marker, located by Pedro Flores, and then "to a pile of rocks round the roots of a live oak tree, now nearly destroyed by fire" (Corner 1890:39). This point was between Olmos and Norillo creeks and the line approximates the route of present Jackson- Keller Road. They then progressed southwest to the point of a waterhole "shown to me by Domingo Bustillo, Delgado and others . . . called the real of San Nicolas, or Tomas Herandez" (Corner 1890:39). The next point, located by Manuel de la Garza and Delgado, was due south on the east bank of Leon 
Creek. Then they measured southeast to "L'Aguila," a crossing on the Leon indicated by Pedro Flores. The survey then turned toward the northeast to the "Paso Nogalitos" on San Pedro Creek as indicated by Pedro Flores. This latter line follows the current Somerset Road and Nogalitos Street (County Survey Book F1:28-29). Although James was able to relocate the old boundary markers with amazing accuracy, his bearing proved to be at fault and the survey failed to properly close and was corrected by Francis Giraud in 1852 (Figure 2-2) (Corner 1890:39).

In October 1847, the council engaged a lawyer, Thomas Addicks, to request of the American minister to the court of Spain "a certified copy of the grant or concession of lands from his Majesty the King of Spain to this city, formerly known as the town of San Fernando in the province of Texas and New Philippines" (CCM A:129). On January 26, 1852, the mayor was able to announce that by a "recent decision of the Supreme Court of the State, the city gained possession of its original limits, and the necessity of defining said limits in order to carry out the contract heretofore made between the city council and Thomas J. Devine" (CCM B:156). The decision cleared the last legal hindrance that prevented the municipality from selling its public lands, first proposed exactly seven years prior. The new plat made by the city surveyor, Giraud, (Figure 2-2), was then the basis for legal definition of the packets of public lands.

When the city received clear title to its public land, the population did not exceed 6,000 and the growth of the settlement had been restricted to the lands watered by the river and the acequias. As a traveler progressed eastward across the San Antonio River, he encountered the broad tree-lined Alameda, a park more than a street. To the north the road led to Alamo Plaza, to the south to the lower missions, and it soon branched southeast to La Bahia or Goliad. The Alameda crossed the old Alamo irrigation ditch and then the eastern branch of the acequia, the Madre ditch. There it narrowed into a dusty trail that led past the Protestant cemeteries and the Spanish watchtower, La Garita, toward the settlements to the east. Branching eastward from the Madre ditch was an old channel that had irrigated the fields awarded to the adaesaños upon secularization of the mission but was now abandoned. Beyond this irrigation ditch there was virtually no settlement and all was a portion of the public lands.
The area south of the Alameda and north of old Goliad Road was platted as District 1, Range 5; this is the area of concern for the Alamodome Project. The areas added to the city east of the river constituted Wards Three and Four, the former being north of Alameda and the latter to the south. The study area contains all or portions of 17 blocks divided from the public lands and sold by the city beginning in 1850 . Seven of the tracts were purchased by J. M. Devine, mayor during the years 1849-1852, the period when the city acquired the right to sell the property. Two of the blocks were purchased by $C$. Fischer, a prominent businessman and later an alderman; and three were purchased by $\mathrm{N}$. de la Zerda, landowner of a substantial holding along the Alameda. These properties were purchased on speculation and were very shortly transferred or subdivided into smaller properties.

Following statehood, Texas became the fastestgrowing state in the south, and one of the fastest growing in the nation. Ninety percent of the immigrants were from the South. These settlers chose the rich bottom lands of East Texas, which within a few short years became a part of the cotton empire. But San Antonio grew along different lines: its main wave of population was from Europe, mostly of German extraction. By the 1850 s, Europeans outnumbered both Mexicans and Anglos. The Americans in San Antonio, with few exceptions, were businessmen and merchants from northern states. Because the economy was centered upon trade with Mexico and support for the army, slavery was never a factor. Yet when the South plunged into war over the issues of states' rights and slavery, Texas joined the Confederacy and raced headlong into the lost cause.

Removed from any combat, San Antonio suffered no physical damage but shared the destruction of its economy and the loss of the finest of her manhood. The money was worthless and massive shortages of almost all commodities occurred. Texas, however, had one major advantage over most of the South: during the war, cattle had bred freely and spread throughout the western part of the state. After the war, the North had cash and a great hunger for beef, so cattle drives began. San Antonio, as the westernmost major city, became the supply and starting point for many of the drives. While this often introduced a rough and untamed element, it also brought cash for rebuilding 


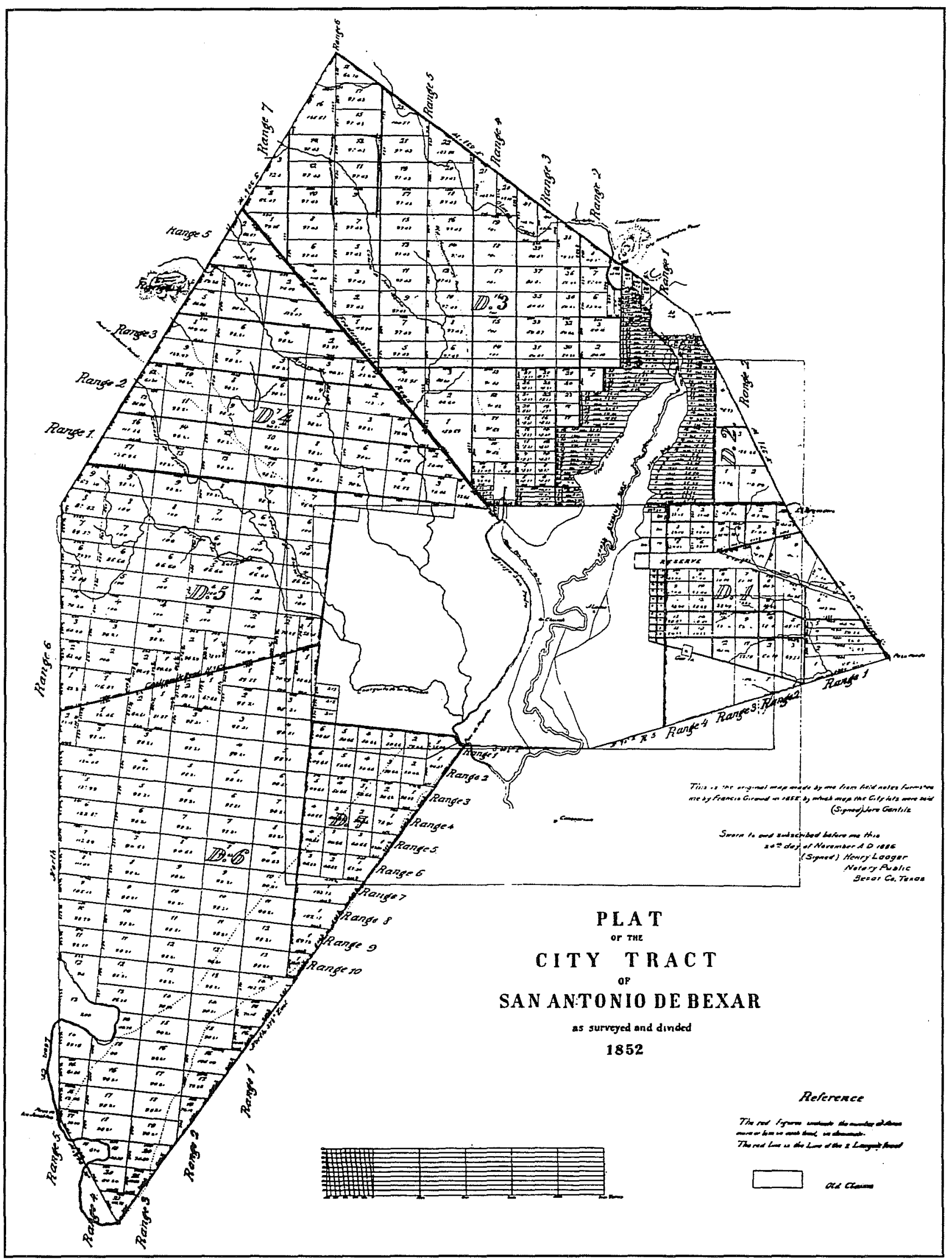

Figure 2-2. Map showing eight-league grant. 
the economy. The town offered little in the way of luxuries and refined graces. Vinton James (1938:133) recorded his memories of the city shortly after the war. "The Plazas were filled with high weeds and stagnant water after rains . . . Dirt and kitchen refuse were relegated to the back yard, which attracted flies by tens of thousands and rats by thousands" (James 1938:133). It is little wonder that in 1866 the town was ravaged by cholera. From the easternmost point of the Acequia Madre, nothing was found but mottes of mesquite and huisache until the isolated Spanish watchtower was encountered atop the rise to the east of the settlement.

During the period between the first land sales within the study area and 1865 , fewer than a dozen structures had been constructed area. All were modest residences, occupied by semi-skilled laborers of German extraction.

On March 26, 1865, a huge cloudburst struck the city and filled the river and creeks to overflowing. The river rose to a height of $14 \mathrm{ft}$ above normal, spreading from its banks throughout the downtown area. The residence of Jacob Waelder, on St. Mary's Street, was demolished by the force of the deluge and his wife swept away to her death. The flood left hundreds homeless, devastated the entire business section, and caused losses into the thousands of dollars (San Antonio Express [SAE], 2 October 1913). In the aftermath of this disaster, the first major flood in over a decade and the worst in memory of the residents, council took immediate action "to repair the bridges, replace them where necessary, and repair and clear the ditches without delay" (CCM C:475). Council also appointed a special committee, consisting of "Captains F. Giraud and G. Scheicher and Mr. Considerant to ascertain and investigate various encroachments upon the river and other impediments, to what extent the rise of the river is owing to the existence of the same; what steps ought to be taken in the premises and whether or not a widening of the San Pedro Creek, within certain limits of the city, would be advisable" (CCM C:475).

Among their recommendations was a new solution to the recurrent problem of downtown flooding.

A sufficient amount of water can be taken out of the river at the upper dam to supply three ditches as well as one of them, instead of following the Alamo ditch, if another ditch were made from where the Alamo ditch opens into the flat above Alamo City, taking in a large part of the ground between Alamo City and the foot of the Powderhouse Hill, a large scope of property, now comparatively worthless, could be supplied with water facilities and increased in value to a very great extent, and this new ditch could receive sufficient capacity to supply the Concepcion ditch (CCM C:475).

Alamo City refers to the development opened by Samuel Maverick immediately north of the Alamo, and the other lands are the public lands east of the city toward the city cemeteries. The committee also points out that if the lots had not been already sold, the cost of the additional ditch could have been paid for by the increased value of the property; however, since the lands were already in private hands, they proposed a special tax for the water to be levied against the owners who would benefit from the increased value to their property. They also stressed the additional advantage that the channel would intercept future flooding and drain the water from the surrounding hills. This proposed flood-control channel was destined to develop into an irrigation project that would be known by several names, but most commonly as the San Antonio Valley Ditch.

In May 1868, the San Antonio Herald (7 May 1868) commented on the status of the San Antonio Valley Ditch.

A year ago a plan was on foot to dig a ditch from above the city, along the edge of the Powder House Hill, down to the Mission Concepcion, and lower, if it was desirable; a company was organized, money was subscribed \&c, but it seems to us that when the lamented Mr. Dauchy died, all prospects and hopes of ever having this ditch completed died also. If some enterprising man was to take this matter in hand it could be finished very soon. The city and county have both given their consent. A large quantity of land would by this means become irrigable, and would be worth at least four times as much as it is now.

However, no immediate action was forthcoming. 
While the railroad had linked most of the northern United States for years, the first track in Texas was laid in $\mathbf{1 8 5 2}$ from Harrisburg to Richmond, a total of 32 miles. At that time San Antonio attempted to develop a rail line and floated city bonds for the San Antonio and Mexican Railroad, but nothing-except law suits-developed from the venture. By the 1860 s, San Antonio was the only major city in the United States not serviced by rail or a port, all goods were still transported by mule or oxen. The goods were hauled in huge wagons, some carrying up to 7,000 pounds, over unimproved roads that turned to quagmires in wet weather (Fehrenbach 1968:319). One such shipment passed through the city in late 1868: "an immense train of regular Mexican carts, numbering forty-eight, and as large as good sized log houses, passed down Commerce Street Saturday. . . It took nearly three hundred mules to draw the train" ( $S A E, 20$ December 1868). Excitement on the day before indicated the town's desire for improved transportation,

the Corps of Engineers surveying the route for a railroad between Columbus and San Antonio arrived in our city. A large number of citizens on the Alamo Plaza went out to where the surveyors had pitched their camp, on the hill near Mrs. Dignowity's house and witnessed the proceedings of running the chains from thence to Alamo Plaza [SAE, 19 December 1868].

In February 1874, the issue of additional acequias for the city was again introduced to the city council. The ordinance proposed "the establishing of two irrigation ditches, one east of the San Antonio River to be known as the San Antonio Valley Ditch and one west of San Pedro Creek to be known as the Alazan Ditch" ( $S A E$, 8 April 1874). The resolution was held over to special session on the following day when the vote was taken and passed with only Alderman Fischer dissenting (CCM D:99, 102). On April 4, "quite a large number of citizens met at Karber's Garden" ( $S A E, 8$ April 1874) to discuss the new ditch for the area east of the river. William $H$. Maverick was asked to chair and William H. Young to serve as secretary. Mr. Maverick requested that $C$. L. Wurzbach explain the concept of the project, where upon the latter gave "his vision as to the nature of the work and the means of carrying it out" (SAE, 8 April 1874). A committee of five, "C. L. Wurzbach, Major Kampmann, Messrs. Rummel, Moye and Stumberg," were appointed to "gather information as to the cost of the work, and to propose a plan of assessment for raising the necessary funds" (SAE, 8 April 1874). J. D. Wurzbach, the ditch commissioner, and William Maverick were also added to the committee (SAE, 8 April 1874). The following week the committee returned its report at another public meeting, and a finance committee of "Messrs. Biesenbach, Steves and Hoyer" were added to the original planning staff ( $S A E, 13$ April 1874).

At the May 5 meeting for bids, Alderman Schreiner had the stipulation added that bidders for the excavation of the Valley Ditch be required to post bond "in double the amount of his bid" and that the bids and bond be submitted May 8 (CCM D:108). When the bids were opened, the committee was forced to recommend that "whereas so many bids are defective or extravagant that the board reconsiders its action" and requested "fresh bids to be made on forms furnished by the city" (CCM D:109). When satisfactory bids were reviewed on May 15, Walter Tynan was selected as the lowest bidder; however, Tynan failed to post his bond and Patrick Campbell's bid of $\$ 2,000$ was then accepted (CCM D:108, 109 , 134). The following week council advertised for bids for the six bridges required to span the Valley Ditch, and accepted Perner's bid of $\$ 2,100$ (CCM D:111). The excavation for the ditch was apparently completed by December, for Campbell's statement presented to council and a citizen's committee was already addressing damages caused by recent rains (CCM D:134).

In addition, a proposal had been received from Hugh F. and William H. Young offering to clean the Valley Ditch at no expense to the city; however, this generous offer was contingent upon approval of a petition requested by the Young brothers. They had requested permission to construct a ditch leading out the Valley Ditch, beginning a few blocks below the Alameda (Commerce Street), in a southeasterly direction into the Estrada Survey No. 22 (CCM D:256). This was the property just south of the line of the eight-league grant that had been purchased from the heirs of Joseph A. Crews by Hugh Young in October 1874. Young had then subdivided the property into individual tracts (BCDR 2:164). Hugh Young had established Lots 5 and 6 as his homestead, and the lower extension of the Valley Ditch served this property and those lots toward the north (BCDR 16:466). This extension, known as the Young Valley Ditch, began $190 \mathrm{ft}$ below 
Commerce Street and was approximately three miles in length, terminating at one of the small creeks returning to the river near Mission Concepcion. This ditch qualified as a fourth-class ditch under state regulations, and had several advantages over the Valley Ditch. It was a much shallower ditch that the Valley, which in places reached a depth of $12-15 \mathrm{ft}$, and therefore required much less maintenance. The extension also ran closer to the hills along the east of the city and allowed more land to be effectively irrigated. The flow of the water was calculated to be $1.8 \mathrm{ft}$ per second (SAE, 24 November 1876). By November 22 both new ditches were open and qualified for State Land Certificates totaling 70 sections. The Valley Ditch, with its addition, irrigated nearly 2,000 acres of land (SAE, 23 November 1876).

\section{The Arrival of the Railroad}

On February 19, 1877, the long-awaited arrival of the Galveston, Harrisburg and San Antonio (GH\&SA) Railroad became a reality. The San Antonio Express (20 February 1877) exclaimed "yesterday the people of San Antonio celebrated the completion of our first railroad and the inauguration of the running of regular passenger trains, events that properly take rank high among the most important events connected with the entire history of the city." The first arrivals consisted of over 300 distinguished visitors from Galveston and all points along the route and "eight thousand people put forth their hands to welcome our invited guests" (SAE, 20 February 1877). The railroad depot had been hastily constructed at the western end of the area designated as the "reserve," now the corner of Hackberry and Duval streets at the foot of the hill below Fort Sam Houston. "The freight depot, now one hundred and twenty feet in length, is undergoing an additional extension of sixty feet . . The passenger track now passes it, and will run some distance along the east bank of the Valley Ditch" (SAE, 23 February 1877).

By July 1878 , the city waterworks were in operation. "Another test was given the waterworks last evening. Four hydrants were brought into play, throwing streams much higher than any building in the city under fifty pound pressure. It is contemplated to shortly have a contest between the waterworks and the fire engine in throwing water" (SAE, 6 July 1878). On
July 5 , the chairman of the Special Committee on Water Works, James P. Newcomb, proposed a resolution stating "the city of San Antonio hereby formally accepts the water works constructed by J. B. Lacoste and associates, under the contract made with the city. .." (SAE, 10 July 1878$)$.

Within the project area, streets were originally designated with the names of Texas trees for northsouth routes, and numbers for east-west ones. Thus the streets below Alameda (Commerce) were initially designated South 1st through South 7th. In 1881 city council recognized that to implement efficient delivery of the mail, it was necessary to appoint a special committee to study suitable names of numbered streets in the various wards of the city and eliminate duplication. In March the committee reported that it had found 96 streets requiring new designations; of these 32 were in the third and fourth wards. As a result of the committee's report, the following changes were made: "South of Alameda; South 1st changed to Idaho; South 2nd, Montana; South 3rd, Wyoming; South 4th, Dakota; South 5th, Nevada; South 6th, Nebraska . . ." (SAE, 2 March 1881).

The arrival of the railroad also introduced commercial elements into the area. Edward Steves had settled in San Antonio in 1866 and established a lumber business at Blum and Bonham streets shortly thereafter. With the arrival of rail transportation, Steves could rapidly receive timber from east Texas mills, so he established a yard nearer the terminal. He purchased a lot at the eastern corner of Walnut and Alameda for his new yard in 1883 (Steinfeldt 1978:88). On March 20, Steves and Sons requested "permission to construct a railroad switch on Alameda, east of the railroad, on Block 21" (SAE, 21 March 1883).

The following year another commercial element was introduced into the area: the Holmgreen foundry moved from downtown to the mesquite flats adjacent to the rails along the west side of Walnut Street. The iron works had initially been established at the corner of Market and Presa streets in 1876 by Jacob Schuhle and R. G. Nixon. Two years later the business was acquired by George Holmgreen and his sons, Julius and Eugene, and renamed Holmgreen and Sons. As the business prospered it began to create such a clamor in the midst of the city that several citizens declared it a "public nuisance" and petitioned council for action 
(CCM E:232). Council ordered the city engineer to inspect the situation. In April 1881, the engineer reported that the "foundry is dangerous to property on account of fire. After seeing it in full blast, I am convinced that with a south wind the uncovered chimney would be excessively dangerous to neighboring property" (CCM E:253).

Alderman Lockwood then proposed a resolution that the property owner remedy the situation at once (CCM $\mathrm{E}: 253)$. The Holmgreens elected to remove their operation to a remote site rather than continue to face these problems at the present location. They selected a lot originally purchased by James Gray and resold to J. B. Lacoste, who conveyed the property to Holmgreen in 1883. On March 17, 1884, Holmgreen requested permission from city council to "establish and run a foundry on Block 5, fronting on the junction of Montana and Walnut Streets in the Fourth Ward" (CCM F:17). The business, now christened Alamo Iron Works, expanded into a foundry, machine shop, and seven other buildings within four years and was destined to grow and occupy the site for over a century.

Although the city was elated with the arrival of the railroad, the association was not without its problems. The location of the depot at the foot of the hill below the new army headquarters was somewhat removed from the center of town, as the city fathers had envisioned. Consequently, the most direct approach, Austin Street, began to grow with support businesses, somewhat to the detriment of the old business district on Commerce. This growth created a boom in real estate in the immediate vicinity of the depot. What had once been open lots became a thriving business section extending over seven city blocks from Ninth to Van Ness streets, as well as the intersecting streets. Stores, restaurants, boarding houses, and saloons turned the area almost overnight into what appeared to be a small city on the edge of a prairie, a district that soon acquired the nickname "The Levee" (SAE, 22 July 1934).

The railroad company was also overpowering in its pursuit of its rights-of-way. In March 1881, several citizens residing along Walnut Street filed a complaint against the Galveston, Harrisburg and San Antonio Railroad demanding "full compliance with the law in regard to the construction of suitable crossings at all intersections" (CCM E:232). The city ordered that correction of the situation be initiated within two days and completed within eight. In April, Alderman Niggli protested the action of the railroad in the further expansion of their right-of-way toward the western portion of the route, charging they were not in compliance with either state or city ordinances and "had excavated and utterly destroyed Walnut Street" with the construction of their roadbed (CCM E:241). The city immediately passed an ordinance requiring that the railroad "restore Walnut and other streets" within 90 days to such condition "as will not unnecessarily interfere with the use of said street for ordinary travel" (CCM E:241). The conflict was to be waged for several months, but finally in January 1883 the citizens of the area requested that council withdraw the suit against the company. Alderman Henry Pauley, "the champion of Walnut Street and the fourth ward generally, opposed the petition against the G.H.\& S.A. railroad, they agreeing to do the work required when connection between the two roads was completed, saying that the merchants and businessmen on Commerce Street, were totally ignorant of the fact in the case, and knew not what they were asking for" (SAE, 17 January 1883). The reference to the "two roads" concerned the long awaited linking of the railroads to the Pacific coast, completing the route which became known as the "Sunset Line."

The water works continued to expand its coverage of the city, but the bulk of service was concentrated on the downtown area. In March 1882, the company added an additional $36,000 \mathrm{ft}$ of water main, but the expansion in Ward Four did not extend east of Labor and Matagorda streets, several blocks west of the subject area (CCM E:319). It would be over a decade before full service would reach beyond Plum Street and into the area. Growth was still slow and predominantly German, with two or three black families interspersed within the neighborhood. Yet, an additional ethnic group was introduced by the arrival of Alamo Iron Works: the Poles. The foundry was almost exclusively manned by Polish artisans, and remained so for several generations.

At this time the city began to recognize the need for increased sanitation facilities of the rapidly growing metropolis. Mayor French, in his report to council upon his fifth return to office in 1882 , addressed the 
problem of the requirement for a proper sewerage system.

I cannot refrain from urging upon you the necessity for an early consideration of this most important subject. Heretofore there has been a very decided disinclination, both on the part of the Council and citizens to its consideration, on account of the great expense it was supposed to entail . . . the cost of proper sewerage is inconsiderable when contrasted with the benefits that ensue therefrom [CCM E:291].

A bond issue was proposed at that time to expend $\$ 50,000$ to develop a proper system, but was defeated by a vote of 335 to 149 (CCM E:343).

In June 1882, George Caen requested "the sole privilege, for ten years, of excavating, emptying and removing the contents of all privies in the city" (CCM $\mathrm{E}: 342$ ). The city agreed to his removal of the contents but the city attorney ruled that the city could not enter into a contract for the exclusive right (CCM E:354). Apparently that agreement was satisfactory to $\mathrm{Mr}$. Caen, for in October he requested that one of the softrock quarries be set aside and leased to him as a "depository for the contents of privies, \&c, to be used for the manufacture of fertilizing material" (CCM $\mathrm{E}: 377,383$ ). The soft-rock quarries were essentially caliche domes that were saw-cut into blocks and allowed to dry to form cheap building stones. The principal quarries were located east of the study area near the city cemeteries on Commerce Street. Permission was granted for his use of a quarry in block 22 on East Houston Street, where Caen established the San Antonio Sanitary Fertilizing Company. The company produced a composted product that was vended to area farmers for use on their produce crops.

In 1884 the problem of sanitation was again forced upon the city. The West Texas Medical Association met in San Antonio at the end of August and its president, Dr. Tyner, expressed his opinion that the city had reached "a size and importance imperatively demanding a change in the disposal of its sewerage. The primitive means of its disposal answered while it was a village, but such is inadequate now, to a population of 30,000 , and cannot continue without disastrous results, which will not only effect its health but its commercial prosperity as well" (SAE, 30 August 1883). He stressed the absolute necessity of removing filth before decomposition and emphasized that the current system of privy vaults and cesspools was totally inadequate. At the council meeting of September 4, the ditch commissioner reported that filth was being conducted to the Madre ditch "from the U. S. hospital, Major Kampmann's residence and the Menger hotel" (SAE, 5 September 1883). To that, Alderman Lockwood retorted that he "had no idea there was no one who did not know it was impossible to keep the water in the ditches so it would be fit to drink. Two-thirds of the diseases in this city come from that source" (SAE, 5 September 1883). At the next meeting of city council Alderman Lockwood presented a resolution.

Whereas, it is well known to every member of this council, and to every intelligent citizen of this city, that the water of the San Antonio River and San Pedro Creek, and the Alamo or Madre, and Alazan and San Pedro ditches, and all their branches, after entering the city limits, are unfit for drinking or domestic purposes. And whereas, it is utterly impossible to keep the water of said streams and ditches, pure and undefiled in their devious courses through a city of 30,000 people, living along the banks of said streams and ditches. And whereas, it is a recognized and established fact, that the San Antonio River and the San Pedro Creek, are the natural drains of this valley. Therefore be it resolved, that the San Antonio River and the San Pedro Creek, the Alamo or Madre, Alazan and San Pedro ditches, with all their various branches, are hereby declared to be a part of the system of drainage, and the people are hereby notified not to use said water for any other purpose than irrigation [CCM E:520-521].

Alderman Bolton then suggested that the mayor engage the services of "some well known engineer expert" to devise a complete sewerage plan for the city. At this Alderman Belknap asked: "Have they no confidence in the council?" Alderman Bolton replied: "Not that exactly; but they would have more confidence in an engineering expert" (CCM E: 520-523; SAE, 19 September 1883). A new bond issue for $\$ 350,000$ was placed before the voters, who rejected it by a count of 956 out of a total of 1,341 (SAE, 24 March 1884). Obviously, San Antonio was not yet ready to fund 
what everyone recognized as an essential step toward modernization.

As the year 1885 began, the city again went to the polls to elect a new mayor. Mayor French, who had held the post for a full decade, chose to run for alderman of the third ward rather that stand for reelection. The position was captured by an energetic young lawyer, Bryan Callaghan. His father, an Irish immigrant who had married Concepción Ramón, a descendant of one of the Islanders' families, had been mayor in 1846. Young Callaghan received his formal education in France and, with his fluency in Spanish, French, and English, bridged all facets of the diverse political structure of San Antonio. Upon assuming office, he stated his position on the needs of the city: "I was elected as a democrat on a liberal and progressive democratic platform. In the recommendations I have to make, the first and foremost is a system of sewerage" ( $S A E, 1$ February 1885). This new stance seems ironic, considering that 10 months prior Callaghan had been a major factor in defeating the issue.

The arrival of the railroad had the anticipated effect of thrusting the sleepy old city into the expanding economy of the rest of the nation; the population increased to 30,000 people and was rapidly expanding. However, the expected growth of the study area envisioned by speculators was slow to come. The majority of the growth had occurred near the rail terminal in Ward Three, well to the north of Commerce Street (near Ft. Sam Houston). By the mid1880 s, the only substantial development in the study area was the industrial growth along the tracks near Alamo Iron Works and the Steves Lumber Yard. The rest of the area consisted of only scattered residential housing. It was not until October 1885 that the first water main was installed on Plum Street and the second main, on Santa Clara Street, the following year (SAE, 8 October 1885, 16 February 1886).

\section{Civic Improvements}

In August 1887, the city proposed an ordinance to regulate the "emptying of privies, vaults and sinks and to license the same" ( $S A E, 3$ August 1887), requiring all persons so employed to obtain a $\$ 100$ annual permit. The ordinance also prohibited individual occupants from undertaking this function on their own. It set the rate at " $121 / 2$ cents per cubic foot of matter" (SAE, 3 August 1887). At the following meeting of the board, Alderman Gallagher moved that the "Cavanaugh system"-an odorless method utilized by John Cavanaugh-be adopted as the required method of cleaning privies. Alderman Smye objected that this could lead to a monopoly. Gallagher countered that he was only following the recommendation of the board of health for an odorless system. The mayor explained that the board was in favor of the Carrico (siphon) system used by Cavanaugh. Alderman Degener interjected that Cavanaugh was not now using the Carrico system, but instead a pump system for cesspools. Council finally agreed that any "tank and pump system" could be used as long as it qualified as "odorless" (SAE, 9 August 1887).

On August 20 of the previous year, the city had been struck by a devastating wind storm and pelted by heavy rains from what remained of a hurricane that swept through Galveston and southern Texas; however, since that time there had been virtually no rainfall and the area was thrown into a severe drought. By mid-year the river had dropped to a critically low level. A great deal of speculation on what course of action should be taken to insure a public water supply ensued. One comment to the press is extremely revealing as to the state of the Valley and Young ditches: "the ditches are still maintained, and by a foolish and extravagant experiment made a few years since, the city added to the irrigating capacity the Alazan and Mission ditches. The latter had long since been abandoned as a nuisance" (SAE, 21 August 1887; emphasis added). The "Mission ditch" referred to is obviously the Valley system. Although apparently no longer in operation as an irrigating system, the ditches remained open.

In early May 1887 , the city engineer was directed to examine "the $d r y$ ditch on Walnut Street and give an estimate of the cost of cutting out obstructions in same so as to allow accumulated water to drain properly" (CCM G:660; emphasis added). Apparently, action was not taken soon enough, and two weeks later, $\mathrm{Ed}$ Steves complained of "damages to his lumber, shingles, $\& c$, by the overflow of the Alamo Valley ditch at Cherry Street" (CCM G:665). By the fall of 1887, the ditch commissioner for the east side was no longer claiming expenses for the maintenance of the system (CCM H:50-51). In May 1889, the street commis- 
sioner is directed by council to "drain the ditch on Walnut Street from Nolan to East Commerce" (CCM $\mathrm{H}: 243)$. This area was six blocks north of the project area. The following month, the citizens between Burnett and Dawson streets (two blocks further north) requested that the ditch be filled. The city engineer did not, however, concur with this request, but instead recommended that the street commissioner "fill up low places and cut down high places in the ditch so as to drain" (CCM H:279).

The city continued to seek a solution to the problem of elimination of its growing accumulation of solid waste; one proposal submitted was the use of "garbage furnaces." In October 1889, Alderman Bolton submitted a resolution to "build and erect two garbage furnaces on the east and one on the west side of the city" (CCM H:477). A special committee was appointed to investigate the effectiveness of the method. Apparently, previous experiments with burning garbage met with little success. Alderman Rogers introduced a resolution that the special sanitary committee "investigate and report upon the subject of sewerage and disposition of garbage, including the practical operation of garbage furnaces now in use in other cities" (CCM H:477).

In March 1890 , the sanitary committee reported on their observation of the garbage burner employed by the city of Dallas, and found it totally unacceptable. They noted that Dallas's system would not handle "night soil," so the city was still required to bury some 15 cubic yards; moreover, "our night soil is more than double that amount" (CCM H:736). They also objected that although the burn site was three miles from the city and had a 60-ft smoke stack, "we could smell the stench of the burning garbage"; in addition they found the cost of fuel to be entirely too high (CCM H:736). In May the committee delegated Gus A. Reimann to visit Pittsburgh, Milwaukee, St. Louis, and Chicago to examine their systems. He found all to be utter failures, with the exception of Milwaukee's. The latter employed a steam-drying method that extracted oil and fertilizer from the residue, which somewhat offset the cost of the system (CCM I:78).

At the council meeting of December 5, 1891, Mayor Callaghan tendered his resignation and A. I. Lockwood was selected by council to replace him on the third ballot (CCM J:326). For the first time since
1885 , "King" Callaghan was not on the throne of city power, but his machine was still entrenched. Only aldermen Schreiner and Hoefling were not staunch members of the Democratic bloc. As the new year approached, the matter of the upcoming election began to dominate the public concern. A swell for political change was growing, not entirely from dissatisfaction, but more from a desire for a representative governing body. "The interest of the city would be best subserved by an entirely new deal alike in the choice of alderman and mayor, and it is no reflection upon the present body to say this . . . Call the roll of the members of the city council and in no respect are they representative of the city" (CCM J:326). A feeling prevailed that the city and county had combined to operate a government in their own interest rather than those of the average citizen. "A change will put more businessmen and fewer hack politicians in the city council" (San Antonio Light [SAL], 25 November 1892).

Mayor Lockwood recognized the feeling of dissatisfaction and chose not to run for reelection; but he was not ready to relinquish control of the government without a fight. At a special meeting of council, Mayor Lockwood was forced to face the opposition's move to insure an impartial election. City Attorney Bergstrom submitted an ordinance to revise the election rules, which Mayor Lockwood refused to place before council, stating that his other legal advisors considered it against the city charter. Alderman Guerguin and several others of the council immediately protested, and Mayor Lockwood declared the meeting adjourned, despite the fact that the majority of council voted against it. The large crowd of citizens present to attend the session arose and protested strenuously. In response, Mayor Lockwood departed the chamber, followed by Aldermen Persch, Conner, and Weber. Upon advice of the city attorney, the remainder of the council retained their seats and reconvened the meeting. The remaining eight members, representing a quorum, elected Alderman Guerguin as mayor pro tem. They then proceeded to pass the ordinance in question, selected the judges for the forthcoming election, and passed a resolution to "express our unqualified disapproval of the action of Mayor A. I. Lockwood by his refusal to act in an impartial manner in taking a vote of the council and hereby express our lack of confidence in him" (CCM $\mathrm{J}: 397-400$ ). They concluded their action by drafting a 
ballot headed "Anti-ring," "Anti-City Ring," and "Independent." A reporter for the San Antonio Express attempted to question Mayor Lockwood to ascertain his view of the actions, "his honor, however, was not to be found" (SAE, 10 February 1893).

The election, held the second Monday of February, resulted in a landslide for change. The Anti-City Ring candidate, George Paschal, defeated Phil Shardein by a majority of 2,502 votes of a total count of 6,404 . The remaining positions were filled with like-minded individuals, thus the old machine was cast out.

Paschal was born on Military Plaza on July 22, 1848, and pointed with pride to the fact "that he was the first newsboy to sell papers on the streets of this city" ( $S A E$, 28 February 1893). Portly and balding with an aggressive moustache and goatee, Paschal was well liked and had served as United States commissioner until elected district attorney which "he filled with signal ability until his election to the mayoralty" ( $S A E$, 28 February 1893). Paschal's council consisted of eight first-time businessmen and four established, antiadministration politicians, including former mayor French and gadfly Mackey (SAE, 28 February 1893).

In 1893 the Garretson Crematory garbage furnaces had been selected by the council and had been constructed and were ready for testing. Two furnaces had been authorized: one located on the east side, about onefourth of a mile south of the city cemeteries on Prospect Hill, approximately three-quarters of a mile east of the project area; the other on the west of Alazan Creek in an unpopulated area. One of the furnaces measured $35 \mathrm{ft} 5$ inches in length, $7 \mathrm{ft} 9$ inches wide, and $9 \mathrm{ft}$ tall; the other was $30 \mathrm{ft}$ long, $4 \mathrm{ft}$ wide, and $3^{1} / 3 \mathrm{ft}$ high. They were constructed on the exterior of "common, yellow brick" with iron doors installed "for putting in the wood and coal and for removing the ashes" ( $S A E, 22$ August 1893). The interiors were lined with nine inches of fire brick, with an iron grate about three feet above the ground where the material was exposed to the flames. A platform with an inclined ramp which allowed carts to dump their cargo into the interior was constructed above the furnaces. "A negro with a pitchfork and broom stands near the door and shoves the garbage into the opening" ( $S A E, 22$ August 1893, 22 November 1893).
Complaints came immediately from several interests, including some of the aldermen, about the effectiveness of the furnaces, generally over the odor produced or the lack of complete burning. At the end of the 30-day test period, the furnaces were rejected by the council. At that point, D. S. Burns appeared before council with a proposal:

in view of the fact of the complete failure of the garbage furnaces . . . I will collect all of the miscellaneous garbage, including dead animals, before $12 \mathrm{~m}$. [midnight] of each day and destroy by fire of 2000 degrees of heat all of the city's garbage and carcasses for the sum of $\$ 12,000$ per year [SAE, 3 October 1893].

The council took his offer under advisement, but in November rejected his offer because "the city is now contemplating the erection of a city prison at the old rock quarries with the view of having the garbage, etc. disposed of there and of utilizing the city prisoners for that purpose" (SAE, 28 November 1893).

In August 1893, a special meeting of council was convened to hear engineer Samuel M. Gray's proposal for the long-awaited sewerage system for the city. "I have been over the city with the city engineer and examined the river and have concluded that it is the largest city for its population I have ever seen. This great area will necessitate more feet of sewer in proportion to the population than would be needed otherwise" (SAE, 22 November 1893). However, he also noted that the lack of "rock or quicksand" would offset the expense of the increased distance. He then addressed the type of system required by the city. In his opinion there was no need for the system to deal with storm water, as would be the case with the combined system, for those areas where this was a problem could be drained directly into the river; therefore, the separate system was in order. Since that system took no rainwater, it was necessary to have "an ample supply of water at a reasonable rate to flush them" (SAE, 17 August 1893). He recognized that the acequias could be used to flush some, but this alone would be inadequate. He spoke of "automatic tanks, which discharge water at intervals of once every twenty-four hours, twice in twenty-four hours or once in forty-eight hours" ( $S A E, 17$ August 1893). Gray also recommended man-holes at the intersection of every street. "As to the size of the sewers San Antonio can 
have the smallest one relatively of any place which I have encountered. There is absolutely no ground water and there is little from the roofs" ( $S A E, 17$ August 1893). Yet, he still advised that no pipe be laid of less than eight inches, for "the additional cost of the eightinch sewers is chiefly in the cost of the pipes and marble cement to lay the joints" (SAE, 17 August 1893).

Gray then spoke of methods of disposing of sewage: "first emptying the crude sewerage into rivers with which we are familiar and many cities know to their sorrow. Second, chemical precipitation, and third, irrigation or filtration" (SAE, 17 August 1893). Gray cited cases where cities were pouring their sewerage into rivers and contaminating them with resultant law suit and injunctions.

If the sewerage here can be put into the river without causing a nuisance it would be the best thing to do with it. The river . . . has a flow of about $67,000,000$ gallons a day, and the estimated volume of sewerage of the city is about $10,000,000$ gallons, or that is what ought to be calculated on. It would pollute the river so that it would be unfit for stock to drink anywhere near the place of output [SAE, 17 August 1893].

The engineer then offered to develop a full plan and specifications for the city at a cost of $\$ 5,774.00$, which the council immediately authorized (CCM K:38).

In July 1894 , Gray's sewer report was presented to the council. It had been compiled in great detail and included a vast array of maps and profile drawings of the grade, depth, and placements of all components. After a lengthy reiteration of the various methods of disposal of the waste, Gray presented his analysis of the particular need of the city: "I therefore recommend for your adoption the separate system of sewerage, modified to the extent of admitting a limited amount of storm water from the roofs of buildings" ( $S A E, 10$ July 1894). The sewers were designed, when flowing half full, "to carry 0.16 cubic feet per second per acre for the central and business part of the city; 0.0115 cubic feet per second per acre for the resident portion of the city, and 0.008 cubic feet per second per acre for the extreme suburban portions of the city" ( $S A E, 10$ July 1894). These figures were computed to accommodate a daily flow of 150 gallons per capita, projecting 70 persons per acre in the center, 50 in the residential, and 35 in the suburbs.

The next point of consideration was the method of disposal of the sewerage, for which Gray recommended irrigation, filtration, or a combination of the two. "Irrigation or filtration through land consists of discharging the crude sewerage upon the ground, the courser material being left on the surface, while the finer material passes into the earth to a greater depth, depending upon the fineness of the particles in the sewerage and the coarseness of the soil" (SAE, 10 July 1894). The distinction between the two methods is that in irrigation the soil receives only enough sewage to be beneficial to the growth of crops, thereby allowing dual usage of the acreage. For the sewerage farm, Gray stated that the usual formula called for one acre of land for each 200 inhabitants, or about 500 acres for a city of this size; however, it was not necessary to purchase the entire tract at once but allow for expansion as needed. The plan required 145.75 miles of sewer and was estimated to cost $\$ 378,979.26$ (SAE, 10 July 1894). Council immediately voted to set a bond election for August 7. The Alamodome Project area was included in the eastern district as a portion of the "suburban area." As was always the case with improvements for the city, there was a great hue and cry both for and against the issue; however, when the votes were counted none of the wards carried a majority against the sewerage bonds, not even the "mossbacks" of the Seventh Ward. The newspaper reported,

the majority is large enough to warrant that the taxpayers, without pressure of any kind, voted for the bonds in sufficient number to have carried the day. This vote of confidence should be sufficient for the mayor and City Council to proceed with the work of construction without the appointment of any committee of citizens-if they get the money [SAE, 8 August 1894].

In January 1895, the council authorized the improvement of the streets in the Seventh Ward. They resolved "macadamizing East Commerce street from Walnut to the cemeteries, plowing and grading South Pine street from East Commerce to Dakota, and graveling and rolling Santa Clara street from Walnut to Goliad . . . and plowing and draining South Cherry street from East Commerce to Runge's store" (CCM 
L:18). Improvements continued to be made throughout the ward, but in late 1897 they were just installing water mains into the area, namely on Wyoming Street (SAE, 14 September 1897). As late as 1911, sewer mains were installed on Mesquite Street from Dakota to Dashiell streets (SAE, 7 March 1911).

\section{The Twentieth Century}

In late 1900 , the city began to realize that the old city cemeteries would no longer serve the growing city. The city health officer, Dr. Frank Paschal, submitted the following communication to council: "According to the statement of Mr. Robbins, city sexton, the available lots in the city cemetery will not last longer than three months, when other ground must be obtained for burial purposes. He also states that the city owns land in the vicinity of the present cemeteries that could be used for this purpose, but which would do only for ten years." In view of these facts, Paschal recommended that the city consider discontinuing the use of the present location and instead "establish a new cemetery removed from the center of the city, and to close the cemeteries on the east side of the city, except to those owning lots, and to the benevolent societies that own their cemeteries" (SAE, 13 November 1900).

At the same session of council, a communication was received from J. T. McQueeney, superintendent of the GH\&SA Railway Company, requesting an ordinance be passed for:

granting the right to lay and construct one or more tracks, side tracks, turn-outs and switches, to and along Walnut Street and across Centre, East Commerce, Santa Clara and Montana streets, and over, through and across any alleys lying between Montana Street and East Commerce Street, with the right to maintain and operate its line of railway over said track; also the right to close Gonzales Street from the western line of lot 7 , in city block 679 , to Walnut Street; also the alley between Gonzales Street and East Commerce Street, in city block 679, from the west line of lots 6 and 13 of said block to Walnut Street [SAE, 2 April 1901].

The stated purpose of the closures was to allow "the erection on said property of a passenger station which will be an ornament and benefit to the city at large"
(SAE, 2 April 1901). The ordinance was passed without a dissenting vote.

The railroad, having reached the Pacific coast, was now part of the Southern Pacific Railways and was popularly known as the Sunset Line. In April 1901, officials announced that the railroad had placed the plans and specification for the new depot into the hands of the company's engineers in Sacramento, California, and work would begin as soon as they had been approved and forwarded to San Antonio.

The depot is to be built entirely of brick and iron. The main building will be two-stories in height, containing the waiting-rooms, ticket offices, dispatchers departments, etc. In the annex to this there will be located a handsome dining room, express office and storage rooms" [SAE, 2 April 1901].

The initial cost of the structure was estimated at $\$ 55,000$, with planned improvements that would raise the total cost to between $\$ 80,000$ and $\$ 83,000$ (SAE, 2 April 1901). In June, E. B. Cushing, engineer of maintenance of way for the railway, arrived in town to inspect the site selected for the new depot. He was unable to release a start date for construction, but did contribute that the depot "will be a great deal more elaborate than was first contemplated, and that it will be one of the handsomest stations to be found in any division of the road. It is said that over $\$ 100,000$ is to be expended in the construction thereof" ( $S A E, 28$ June 1901). The impressive mission-style structure, known as the Sunset Depot, was completed the following year and remained one of the most attractive structures in the city for many years (Figure 2-3).

At the beginning of the twentieth century, the population of San Antonio was 53,321, an increase of over 15,000 from the census of 1890 . Yet the next 10 years would herald an even more dynamic period of growth, for during the next decade the city would almost double its population. The entire country was swelling and embracing the industrial and technological revolution that was opening the fields of communication, transportation, and manufacturing. The telephone was a familiar fixture, radio was in its infancy, and the nation would soon see the introduction of the automobile and the airplane. 


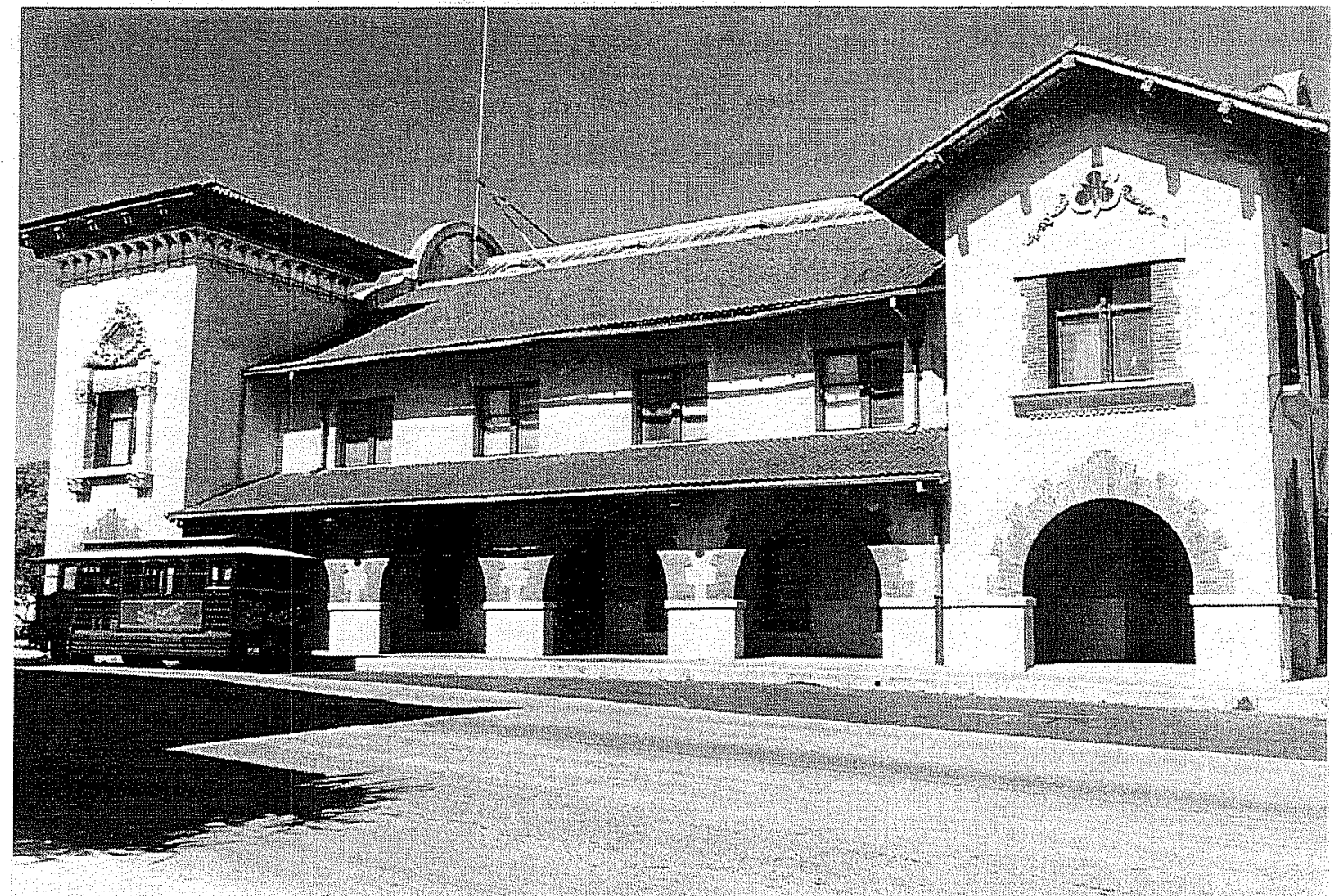

Figure 2-3. Sunset depot.

Deprived of their original purpose, the acequias had evolved into an expensive luxury. Alderman Fentiman introduced an ordinance appropriating $\$ 1,000$ for the opening of the Madre ditch from Tenth Street to its termination at the river; the intended purpose was to allow the drainage of storm waters during the heavy rains that were frequenting the city. The neglect of the ditch had allowed the waters to pool in the streets to the point that many blocks had been rendered impassable to pedestrians; in some parts the water was rising to as high as one or two feet on the streets and sidewalks during heavy showers (SAL, 14 July 1903). The ordinance was approved during the first session of August, at which time city engineer John D. Rullmann presented his proposition to turn storm water into the ditch at Martinez Street. He recommended that all storm water from Burnett and Sixth streets be conducted over Avenue $C$ (Broadway) by surface drainage directly to the river; all water south of Burnett and west of Cherry streets be conducted to the Madre ditch and hence to Martinez Street and the river. He further suggested that the water from North and South streets should be relieved by reopening the old Alamo ditch from the north side of North Street to its intersection with the Madre ditch (SAE, 4 August 1903).

At the end of June 1905, the city experienced another of its frequent torrential downpours, over three inches of rain in less that 24 hours. The rapid rise turned Bonham Street into a "navigable stream," noted as being able to "float a loaded skiff" ( $S A E, 27$ June 1905). The water was knee deep and covered the sidewalks on both sides of the street. "Some months ago Mr. Rullmann suggested a remedy to the city council. This was approved and the Street Commissioner was authorized to do the work. The work was never done and the conditions as they existed are unchanged, unless it is from bad to worse" ( $S A E$, 27 June 1905). This is a reference to the engineer's recommendation of 1903 regarding the clearing and grading of the old ditches and utilizing them as storm drains for such downpours ( $S A E, 27$ June 1905).

Six months later, street commissioner Russi proposed a solution to the drainage problem that had been plaguing the wards to the east of the river. "When the work planned is completed Mr. Russi believes the 
Blum Street and East Commerce Street districts and the large area of the Seventh Ward that is impassable after rain will be absolutely relieved" (SAE, 27 June $1905)$. Since the major contribution to the flooding was from the run-off from Dignowity and Dreiss hills, he proposed to fill the "Cherry Street ditch" (the old Valley ditch) and install a high curbing on the western edge to drain the water into Nolan Street and to the south into Wilkins Creek. From Nolan Street north, the flow would be conducted by culverts under the street and directly into the river ( $S A E, 3$ January 1906). In April the city council passed a resolution requiring that all residents of Cherry Street "where the Street Commissioner's men are at work, put in threeinch pine board curbing" (SAE, 17 April 1906).

Construction of the Sunset depot on East Commerce Street also caused the development of facilities for travelers within the area. In 1907 the Mission Hotel was constructed, the following year the Fairmount Hotel was opened, and the Lone Star Hotel in 1910. Steves Lumberyard, which had been located on Commerce Street in 1883, expanded to take advantage of the proximity of the depot immediately to their west. The area also experienced the introduction of more commercial ventures along the rail line. In 1904 the Otto Zirkel Monument Works relocated to Wyoming Street on the eastern side of the tracks.

On Tuesday, February 26, 1907, a fire broke out in the ceiling of the Sunset depot. Since the fire was contained between the ornately plastered ceiling and the heavy tiled roof of the structure, it burned furiously, well out of reach of the efforts of the fire department. The firemen were further hampered by a lack of water mains in the immediate vicinity of the depot, requiring them to depend upon the older steam pumper which delivered a less powerful stream of water. The men attempting to fight the fire within the structure were in constant danger from the falling plaster and glass. Despite all efforts, the interior of the structure was entirely gutted. The division superintendent, H. F. Anderson, was able to rescue all the station's records. Anderson removed the records to the adjacent Mission Hotel, where he established a suite of offices from which to conduct business. Plans began at once to obtain materials and plans for the rebuilding of the edifice ( $S A E, 28$ February 1907).
Later that year Mayor Callaghan announced his plans to reorganize the city's garbage collection system. He proposed replacing all the cumbersome two-wheeled carts with wagons drawn by a double team of horses. The carts had been the method in effect for over 20 years, but the mayor argued it would take no more time for the wagons to make the two daily trips to the dump, and their capacity would be much greater. "Further than this, the Mayor will likely insist upon better animals drawing these wagons. In the past there has been some criticism made concerning the kind of horses being foisted upon the city and used in the garbage carts" (SAE, 21 July 1907).

In March 1911, the Southern Pacific Railway presented a petition to council for permission to expand the track layout near the Commerce Street terminal. They desired one track across Galveston and along Santa Clara; two tracks along Montana to Walnut; three tracks along Wyoming to Walnut; and two cross-over tracks on Walnut Street. The petition, submitted by Anderson, maintained that the increased trackage was required as a result of the rapid growth of the area (SAE, 14 March 1911). Also that month, the sewer system was being expanded on the eastern edge of the project area. Alderman Smith, chairman of the Sewer Committee, reported that $237 \mathrm{ft}$ of sewer was to be installed on Mesquite Street, from Dakota to Dashiell, and $410 \mathrm{ft}$ along Dashiell for $\$ 450$ (SAE, 7 March 1911). This indicated that the system had fully reached the area, but not that all property owners had elected to connect with the system. Some property owners probably retained the option of using whatever system of disposal they had developed until compelled to connect with the system by civil ordinances.

In 1914 the entire continent of Europe found itself involved in a devastating war. America utilized its isolation by the sea to stay aloof from the combat, but still felt morally correct as the arsenal of the Allies. As a growing San Antonio searched for its place in a changing society, the nation continued its struggle to maintain neutrality in a world torn apart by a war driven to the limits of reason by the developments of modern technology. The concessions that Wilson had forced from the German government were seen by that nation as an unacceptable restriction of their ability to exploit their strongest weapon against the Allies. In February, submarine warfare escalated with the sinking of the British liner California, along with 11 
others within a 24-hour period ( $S A E, 8$ February 1917). Within less than two weeks 23,000 tons of shipping was sent to the ocean bottom ( $S A E, 22$ February 1917).

American's neutrality, while acting as the Allied arsenal for resupply, was inconceivable in the eyes of the Teutonic planners. In March a plot was uncovered that made it clear that the United States would soon be drawn into the struggle. Instructions from the German Foreign Minister Zimmermann to Minister von Eckhardt in Mexico fell into American hands, revealing a plot to form an alliance with Japan and Mexico to attack the United States ( $S A E, 1$ March 1917). President Wilson was forced to arm all American ships, and within a month the first armed vessel, the Aztec, was sunk by a German submarine. Wilson immediately asked Congress to declare a state of war (SAE, 2 April 1917).

The city's place in the scheme of the war effort soon became apparent when the War Department announced in June that they planned to expend $\$ 7,000,000$ to equip Fort Sam Houston to serve as the training facility ( $S A E, 15$ June 1917). This entailed an extensive expansion of the military presence in the city. Plans included the construction of a cantonment for 40,000 troops; and a facility to train 15,000 aviators, reservists, and regular army already assigned to San Antonio. The facilities required included the 17,000 acres at Leon Springs, now known as Camp Funston, plus an additional 17,000 adjacent acres; Fort Sam Houston, Camp Travis, and the aviation facility known as the Remount Station on Government Hill; the Downtown Arsenal property; and the three areas already selected and in use at Kelly Field, the primary flight facility. By August the War Department was already searching for an area to be developed for aviation purposes; the field selected was in the southeast near Berg's Mill and named Kelly No. 2 ( $S A E, 30$ August 1917). On November 14, Cadet Sidney Johnston Brooks of San Antonio fell 2,000 ft to his death at the new field on his final flight check ( $S A E, 14$ November 1917); the following month the new aviation field was officially designated Brooks Field in his honor (SAE, 11 December 1917).

Increased rail traffic to the Sunset depot not only caused a growth spurt within the study area, but also changed the complexion of the area. Many of the families left the area to escape the rush of passenger and freight traffic; they were generally replaced by rental tenants who were employed by the Southern Pacific as porters, redcaps, and freight loaders. The Southern Pacific Depot became one of the busiest terminals in the nation with the mass of soldiers being trained at Fort Sam Houston and the airfields.

During the war, San Antonio actively supported the effort by purchasing bonds, conserving food stuffs as directed by administrator Herbert Hoover, and welcoming military trainees into their homes. Although the idea of prohibition ran counter to residents' drinking habits and economic interests, the city backed the issue for patriotic reasons. The booming saloons were closed on April 16, 1918, causing several successful breweries in the city to either close or to produce non-alcoholic beverages at a much lower demand. Texas also displayed her war spirit by supporting women's suffrage, for they were filling the jobs of so many of the men who were off to war, allowing them the ballot two years in advance of the nineteenth amendment. By the time the armistice was signed on November 11,1918 , over 200,000 men had been trained at the military bases in the city $(S A E, 11$ November 1918). Within a month, the War Department began to realign and scale down the facilities. The first move was to merge Camp John Wise, the lighter-than-air balloon school located in the old rock quarry near Olmos Park, with Brooks Field. This involved 106 officers and approximately 2,500 enlisted men. This was taken as a positive sign by the city, viewed as an indication that "both Brooks and Kelly Field are to be retained by the government permanently" (SAE, December 13, 1918).

\section{After the Great War}

In the aftermath of the war, a worldwide pandemic of influenza struck and proved to be the worst on record for the 200 years that the virus had been identified. This specific form proved to be so virulent that doctors were baffled and questioned if it might not be a new disease or poison of the nervous system ( $S A E, 10$ December 1918). More than 4,000 cases were reported from October to December ( $S A E, 10$ December 1918). Worldwide the disease took $10,000,000$ more lives than did the war; 500,000 died in the United States alone. 
Concern for the ever-present threat of flooding from the river was always a consideration during years of increasing prosperity. In the growth following the war, talk of flood control and the straightening of the river came from several groups within the city, each with its own scheme for controlling the stream. While this talk of controlling the river progressed, nature continued with its own patterns. At eight o'clock on July 22, heavy showers pelted the city, continuing throughout the next 24 hours for a total of 2.55 inches. Just to the north, Austin recorded 9.37 inches during the same period (SAE, 22 July 1919). Two months later, a deadly storm struck the Texas coast at Corpus Christi and it reached San Antonio on September 14. San Antonio was spared the full force of the storm, but the barometer fell to a low of 29.47 and "the wind raged in gusts accompanied with drenching rain" ( $S A E, 15$ September 1919). In October, the city received rains that again flooded the Olmos and San Pedro creeks, raising the San Antonio River $7.5 \mathrm{ft}$ ( $S A E, 17$ October 1919). While the improvements over the recent years allowed the water to remain within the banks, the point was brought sharply home that the problems of the city had not been solved. As if to emphasize the unpredictability of the climate, the rainfall for 1917 was only 10.11 inches, while 1919 recorded 50.30 inches; the driest and wettest years of record.

Disastrous floods in 1913 and the near flood of 1919 convinced city officials that action must be taken to avert a major disaster. Some improvements had been accomplished, such as the "sea walls" constructed in the "big bend" area of downtown and the restrictions that had been placed upon construction along the river between Josephine and Mitchell streets. In fact, the placement of the auditorium along the river was to a great extent a flood control measure; by using bonded river improvement funds they planned to eliminate a major bend of the river to create the construction site, thus solving two problems with the single expenditure of bond revenues. Yet all these measures were merely partial fixes to a very complex problem. Those involved with the aftermaths of every major flood since 1865 knew that a final solution entailed straightening the river and removing all impediments to the free flow of water; however, this was not an easy or popular solution. A majority of the citizens were too fond of the picturesque, winding stream to have it converted into a widened concrete canyon slashing through the heart of the city. In addition, several of the major restrictions to the flowthe dams along its course-were still commercially important to several industries. It was obvious that an outside agency was required to make a careful study of the situation and offer an unbiased evaluation.

In the spring of 1920, Commissioner Ray Lambert was instructed to locate a firm to study the problem and produce an in-depth report to address the final solution to future flood hazards. The commissioner contacted the firm of Metcalf and Eddy of Boston, Massachusetts, and requested an estimate for a complete study of the alternatives. They submitted a bid of $\$ 10,000$ to produce a report that would address both past historic floods and develop substantive solutions and cost estimates of corrective measures. The final report was submitted to the city on December 6, 1920 (Report to the City of San Antonio, Texas Upon Flood Prevention; Metcalf and Eddy, Consulting Engineers, 14 Beacon Street, Boston, Massachusetts). The estimated cost of this construction was placed at $\$ 4,000,000$; that figure included $\$ 950,000$ for a detention basin on Olmos Creek. The firm acknowledged that discussions with the city government had already indicated that the expenditure of this amount of money was not considered possible at this time due to "other urgent needs of the city." Therefore, they recommended the immediate expenditure of $\$ 2,500,000$ for what they considered the most critical needs within the period of the next five years. They concluded their study with a rather dire prediction concerning the next major flood:

When such a flood will recur, no man can say. But that it will recur is certain. Therefore, with the rapid growth in value of property in the city, particularly in the congested value and commercial districts, it is imperative that this danger be recognized and that the work necessary to prevent serious injury from flooding be undertaken as rapidly as the financial resources of the city shall permit-lest when the flood comes it shall find the city unprepared and do ruinous damage [Metcalf and Eddy 1920:ii]. 


\section{The Hundred-Year Flood}

After the record rainfall of 1919 , the city again began a drought period. In 1920 the total rainfall for the year was a mere 19.56 inches, almost 10 inches below normal. The first eight months of 1921 promised no respite from the dry spell, with only 17.84 inches, a full inch below normal. Finally on September 9, there was news of a break in the drought: "The most timely showers since 1919 have fallen over Southwest Texas in the past two days, coming just as stockmen were facing the prospect of buying feed or shipping their cattle to other pastures from the depleted range" ( $S A E$, 9 September 1921).

The rainfall that was beginning to break the drought in West Texas was the result of a tropical disturbance that had formed in the western Gulf of Mexico and had crossed the Mexican coast south of Tampico on September 7. In San Antonio a light shower of 0.53 inches occurred on September 8 as a result of the moisture from the leading edge of the air mass, but the main thrust of the storm did not reach the city until between midnight and 1 A.M. on the ninth. At that time steady rains began to pelt the city and continued throughout the night. The rainfall began to intensify throughout the day and continued into the next day. The storm was manifest as an entire series of intense thunderstorms, with driving sheets of rain and deafening thunder that passed over the town one after the other and continued with no relief until midmorning of September 10 (Ellsworth 1923:8-10). The actual amount of rain varied considerably within the San Antonio River basin: more than eight inches recorded within the downtown area, with over 17 inches reported in the upper Olmos Creek basin.

At first it appeared that the improvements to the river would be adequate to contain the deluge, for the initial level was scarcely a foot above normal, but then a

wave from the Olmos, down the valley northwest of Brackenridge Park, struck the headwaters of the river and forced it beyond banks. Within an hour the rise had passed through the limits of the park and water was more than two feet deep on Broadway Avenue, and the river in the downtown section was near the embankments near St. Mary's Street. The crest of the flood apparently was reached about 1:45 o'clock when the water was between 5 and 6 feet deep on Crockett Street . . . and was more than 8 feet deep at Houston and St. Mary's [SAE, 11 September 1921 (Figure 2-4)].

After careful deliberation of the various flood-control projects, a combination plan was adopted. The primary consideration was "the construction of a detention or dry reservoir on the Olmos by raising a massive concrete dam" ( $S A E, 4$ December 1921). The point was stressed that the reservoir must always be kept empty and ready for the next rain. To accommodate the rainfall below the dam, they proposed several alterations to the river channel. These included deepening the channel in selected areas and construction of several cutoffs to straighten the path of the river. The major new suggestion for a cutoff was across the neck of the Great Bend and from a point just above Nueva Street to a point below, taking out the sharp bank at Bowen's Island. The cut, which was designed to be dry until flooding occurred, would allow the shortening of the channel from 4,000 feet to 600 feet and allow for a better slope. The total cost of these modifications was estimated at $\$ 5,500,000$ ( $S A E$, 4 December 1921).

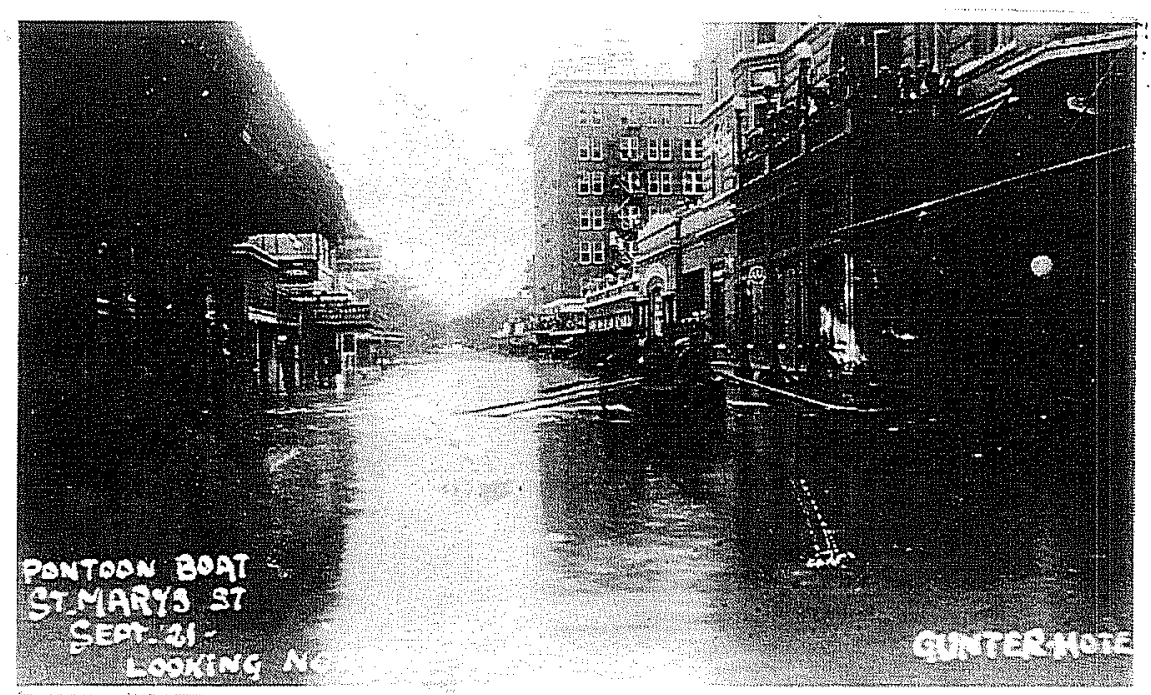

Figure 2-4. Looking north on St. Mary's Street during the flood of September 1921. From the collection of the Institute of Texan Cultures. 
In June 1929, Mayor C. M. Chambers was presented with yet another plan for the beautification of the river. This scheme, submitted by Robert H. H. Hugman, concerned the "big bend" area. Hugman proposed to "divert all water of the river up to a certain level into the new flood channel and permit construction of walks and Spanish type architecture along the banks of the stream" (SAE, 27 June 1929). In reality, the Hugman plan was far more visionary and complex. His vision would create a "miniature Old World Street" along the river lined with "shops of Aragon and Romula." He envisioned Aragon as shops with flowering vines and trees along a cobblestone street between Houston Street and the City Public Service building. Romula would extend along both banks of the river from that point around the remainder of the bend to the end of the cutoff channel at Villita and Dwyer streets. His dream was populated with shops, artists' quarters, cafes, and apartments at the rear of all the present buildings ( $S A E, 29$ June 1929). However, the city council could not supply funding for the project.

\section{Deceptive Prosperity}

The 1920s were times of unprecedented progress and prosperity. Guided by the ultraconservative policies of Calvin Coolidge, the government spent little on public works or housing, and arms expenditures were minimal; as a result, the national debt was reduced by almost 25 percent. Coolidge remarked in his last state of the union speech in 1928, "in the domestic field there is tranquility and contentment . . . and the highest record of years of prosperity" (Hoover 1952:12). After Coolidge chose not to run for reelection, Herbert Clark Hoover was selected by the party to carry on this prosperity into the coming decade. Hoover, in his acceptance speech, stated the hope of his administration, "we shall soon with the help of God be in sight of the day when poverty will be banished from the nation" (Hoover 1952:12). The automobile was within the reach of almost every worker and had given the average man mobility to move away from hard times and enjoy the growing recreational facilities throughout the country. Agriculture was, as always, cyclic but generally low prices had been offset by abundant harvest.

The growing impression of perpetual prosperity was evident in the shifting skyline of San Antonio. The beautiful gothic-revival Medical Arts building towered above the historic old Alamo. The 21-story Milam Building, completed in 1928, was the first structure built entirely on a framework of reinforced concrete, and was also the first to be totally air-conditioned. The Smith-Young Tower, constructed at a cost of $\$ 2,500,000$, was completed in June 1929 , immediately before the Majestic Theater and Office Towers. The Nix Medical building was under construction on the river, as was the Alamo National Bank and the Southwestern Telephone Company high-rise.

Yet not everyone was comfortable with the reckless sense of unfailing market growth. President Hoover, although not allowed to express his fears by the victorious party, had become concerned over the "growing tide of speculation" (Hoover 1952:5). Other economists also raised the banner of caution, but the stock market seemed the path to easy riches for many large and small investors. In March 1929, the market began to stumble, and a downward trend caused prices to slide throughout the summer. On October 24, Black Thursday, the panic began; that day $12,894,650$ shares changed hands, for the most part at prices that shattered the hopes and dreams of their owners. A veteran observer was to comment that there was not a dollar to be lent at the Wall Street Exchange's "money post," and private lending rates had soared. But the experts in capital finance circles were quick to point out that this was the same pattern that had occurred exactly 22 years prior, and a conference held by J. P. Morgan and other major investors insured that "sufficient money was said to have been made available to stop the break and turn the market upward" ( $S A E, 26$ October 1929). They expressed confidence that similar action would stem this latest panic ( $S A E, 26$ October 1929). However, this time there was no salvation and Tuesday, October 29, "was the most devastating day in the history of the New York stock market, and it may have been the most devastating day in the history of markets" (Galbraith 1972:116). The Wall Street crash had little immediate effect on San Antonio. There were few major investors, and almost no industry to feel the immediate capitalistic crisis; the ever-present threat of crop failure was more threatening to the local market. The market crash, though not the cause of the Depression, precipitated it by replacing the inflationary spiral with a deflationary one. The resultant disruption of the economy was such that the city could not for long 
ignore or escape the Depression that was to sweep the nation.

\section{The Presidential Election of 1932}

As the parties assembled at their national conventions to select their candidates in the upcoming election, it was apparent to both parties that the Republicans faced an almost impossible task. Although Hoover had attempted to stem the downward slide of the economy, he had been constantly thwarted by worsening condition in Europe and resistance from the Democrats as well as conservatives within his own party. Prior to the convention, there was even an effort by Republicans to replace him and call Coolidge from retirement, but the latter was not interested. The issue was not so much whether Democrats could seize the office, but who should be the candidate to replace the Republicans. The strongest politicians to emerge were two governors from New York, Alfred Smith and Franklin D. Roosevelt.

Prior to the convention, San Antonio mayor Chambers initiated a campaign to place fellow Texan John Nance Garner, Speaker of the House, in nomination as the party candidate. Although extremely popular, Garner lacked the national backing to secure the confidence of the delegates. Yet, his influence could guarantee the return of Texas to the Democratic party, and Roosevelt offered him the vice-presidency to insure his support. Roosevelt was selected by an overwhelming majority. In his acceptance speech he promised, "I pledge you, I pledge myself, to a new deal for the American people" (Current et al. 1979:662). Thus prior to his election, the campaign acquired a name for its direction: the New Deal. However, the exact direction this New Deal would take remained vague. Roosevelt shrewdly cloaked his policies in generalities. He promised the voters three Rs: relief, recovery, and reform; to this Hoover added a fourth: revolution. Yet the people were ready for change and, in November, Roosevelt carried the election with 22.8 million popular votes, 57.4 percent, to Hoover's 15.8 million, 39.7 percent. Roosevelt had achieved an overwhelming mandate, but the question remained: To do what?

\section{Federal Assistance}

By 1934 the Civil Works Administration was a muchdemanded program throughout the country. San Antonio alone had 18,178 relief workers on the rolls, 1,000 above the initial selection, however, by May the program had to be revised; the relief project had to be reduced in order to stay within the budget. The persons qualified for direct relief were to be furnished with groceries. Those physically able were required to do some work, but many of the projects selected were either curtailed or cut back. In the original plan, those not qualifying for direct relief could be hired as paid workers, but under the adjusted CWA program this was not permitted. Administrator Guy Bonham stated that the majority of the paid workers had offered to take their pay in groceries, but he was required to reject such applications (SAE, 18 May 1934).

After a series of attempts to develop an effective welfare program, the administration finally settled on the Works Progress Administration (WPA). In April 1935, Congress passed legislation approving an expenditure of $\$ 5$ billion to support the concept. Administered by Harry Hopkins, it was to create employment for more than two million workers in the next five years; it was often deplored as a "makework" expenditure of public moneys. However, it is often forgotten that it produced almost 600 airports, 110,000 public buildings, 100,000 bridges and more than a million privies (Current et al. 1979:663). It would also contribute a benefit to San Antonio, the value of which that would go unrecognized for more than two decades.

San Antonio, like cities all over the country, began to search for ways to employ the newly available government funds. One of the first projects that came to mind was the restoration that was being done to beautify Mission San Jose-a joint effort of the city, county and the Conservation Society. The use of relief labor from the WPA was then sought. Upon hearing of this request, Robert $H$. H. Hugman again presented his design for river beautification, first proposed by him in 1929.

We have a priceless beauty spot in our river and could easily make it so that homes and even business places would be remodeled to face the river instead of turning their back doors toward it. 
The plan drawn up proposes to build stairways down to the river bank in the downtown section, and to place benches there for the use of the public. The natural beauty could be enhanced by planting flowers and shrubbery [SAE, 1 October 1935].

Hugman suggested that $\$ 1,000,000$ be applied from the WPA, with the added benefits of flood and malaria control being achieved. While everyone was supportive of his concept, the price was considered too great and the time before the Texas Centennial too short to coordinate the massive project. Instead, an alternate plan for improvement and beautification financed by a grant of $\$ 730,000$ from the WPA was undertaken beginning January 8, 1936 at Concepción Park. The plan called for diverting some of the river's flow into an old section of the channel to "eliminate accumulation of stagnate, mosquito-breeding pools" ( $S A E$, 3 January 1936).

Although the full scheme could not be justified at the time, there was still interest in enhancing the little stream. Fire and police commissioner Phil Wright authorized the use of funds from his budget to provide for the installation of lighting along the river from Travis to Nueva streets during Fiesta Week. This had been a request of the San Antonio Centennial Association, which had even more ambitious plans to emphasize the river's distinctive atmosphere $(S A E, 8$ April 1936). One of the major businessmen who displayed a particular concern about the condition of the downtown river was the manager of the Plaza Hotel, Jack White. White had approached the commission with a request that something be done to "clean up the dirty little river next to the hotel property" ( $S A E, 8$ April 1936). John Richter informed him of the plan that had been proposed by Hugman, and White contacted the architect for ideas to improve the stream.

\section{Flood Control and Beautification}

The concept was one to excite the imagination of the entire country. The New York Times, in their travel section, announced the visionary scheme to their readers, "one of the unusual features of this historic city is the San Antonio River, which meanders lazily through the downtown business district between tree- shaded banks. Recognizing its scenic value, the city has never permitted it to be covered or diverted." They then described the work to be done to make it "the city where you shop from gondolas" (New York Times, 12 February 1939). Finally in mid-March, the city was able to announce that ground-breaking ceremonies would be held at 12 o'clock noon of Friday, March 24, on the river bank opposite the Smith-Young Tower (SAE, 19 March 1939). The following year, the week of the Fiesta de San Jacinto in late April, the first phase of the river beautification was opened to the public, with soft-colored lights along the entire Big Bend and a Sunday night concert by the Tipica Orchestra playing in the outdoor theater (SAE, 29 April 1940).

While the river beautification was in progress, other projects were being promoted in the city. The Conservation Society had taken on the task of purchasing the old Espada aqueduct just to the north of the mission. The beautifully constructed conduit, some $105 \mathrm{ft}$ in length, with its diamond point and two arches, was the last remaining structure of its kind. Mayor Maverick was also diligently pursuing his own pet project-the restoration of La Villita, the old Spanish village in the heart of downtown. Through his direct influence, the city was able to obtain further WPA funds to undertake the task of restoring it into an example of early San Antonio. On August 3, 1939, 25 youths of the National Youth Administration (NYA) began the massive cleanup of the squalor that had turned the area into a slum. With an expenditure of $\$ 10,000$ from the city and $\$ 100,000$ from the NYA, the area was restored into a showplace and connected to the newly improved river bend at the river theater. On Thursday, March 13, 1941, the last remaining work on the river project was completed and Bob Turk opened the gates and turned water back into the entire downtown channel. Since the spring of 1939, the project had improved 21 blocks, some $8,500 \mathrm{ft}$ of river bank, stretching from the South St. Mary's bridge to the Fourth Street bridge. "Construction included 17,000 feet of river walls and sidewalks, 11,000 cubic yards of masonry and 3,200 yards of concrete. Thirty-one stairways from the street level to the river were built with each stairway of a different design" (SAE, 14 March 1941).

A surprise attack by the Japanese on Pearl Harbor, December 7, 1941, provoked the United States into a declaration of war on all the Axis powers. America was again involved in a global war on both sides of her 
two oceans. Only six months after its completion, the festive frivolity of the carnival atmosphere for which the Riverwalk had been created seemed inappropriate in the face of the conflict that the nation now devoted her full effort toward ending. "War dethroned the King and Queen of the 1942 Fiesta de San Jacinto in San Antonio, but elevated their 'subjects' to the job of liquidating the dictators. San Antonio sacrificed this year's Fiesta and its climactic Battle of Flowers for the war effort" (SAE, 24 April 1942). The press echoed the reality that had reached almost every family, that the men who had planned the spectacular 1941 activities "today have answered Uncle Sam's call" (SAE, 24 April 1942). Only the solemn "pilgrimage to the Alamo" to honor the fallen who gave their lives for liberty seemed appropriate and was the only event conducted during the following five years. San Antonio again turned its efforts toward what she had always done best: serving and training military forces.

The city was not disposed to devote funds to lighting or patrolling an area that had little use as a result of the wartime austerity. As a result the river became an undesirable area, subject to frequent mugging, robberies, and intimidations. By the 1950 s, only two establishments catered to the few visitors to the river and many areas had been declared "off-limits" by the military authorities. Business owners in the heart of the city became concerned with the growing exodus of shoppers and diners to the suburban shopping malls and began to seek ways of bringing business and tourism back to the downtown area. In the late 1950s businessmen Arthur "Hap" Veltman and David Straus approached Harold Robbins of the Chamber of Commerce and Robert Frazier, director of the Parks and Recreation Department, with the concept of revitalizing the Riverwalk.

A fund of $\$ 15,000$ was raised and matched by the city to obtain a feasibility study to determine the direction that should be taken with the river bend. This resulted in the creation of the Riverwalk District and Advisory Commission in 1962. A master plan was developed and presented to the voters, who passed a $\$ 500,000$ bond issue in January 1964. At that time the Paseo del Rio Association, an advisory group of businessmen and property owners along the Riverwalk, was established (Zunker 1983:14). Under their direction, the river bend area was returned to its former splendor and developed into the city's major tourist destination.
At the same time, city planners began to consider ways to thrust the image of San Antonio onto the public stage, and the vision arose of hosting a world's fair. Although not sanctioned as an "official" world's fair, the city was granted permission to develop a fair for the Western Hemisphere. Thus HemisFair ' 68 was developed and promoted. An area of declining homes, businesses, and churches was cleared in the heart of the city. The San Antonio River and the Riverwalk were extended into the fairgrounds. In a few short months, a fully developed site was constructed, with private investments contributing hotels, restaurants, and parking facilities. The economic value of the exposition has been questioned, but the impact it had upon tourism has not. At once, San Antonio was displayed to the world and became an international tourist destination. Tourism replaced the military as the leading source of the city's income. San Antonio had again opened its doors to the world. 


\section{References Cited}

Bolton, H. E.

1905 The Spanish Abandonment and Re-location of East Texas, 1773-1779. Quarterly of the Texas State Historical Association, IX(2):67-137.

1915 Texas in the Middle Eighteenth Century: Studies in Spanish Colonial History and Administration. Volume 3, University of California publications in history, University of California, Berkeley.

Chabot, F. C.

1932 Excerpts from the Memorias for the History of the Province of Texas, Memorias by Padre Agustin de Morfi. Privately published, San Antonio.

1937 With the Makers of San Antonio. Privately published, San Antonio.

Corner, W.

1890 San Antonio de Bexar: A Guide and History. Bainbridge and Corner, San Antonio.

Couse, E.

1965 The Expedition of Zebulon Montgomery Pike, To the Headwaters of the Mississippi River, Through Louisiana Territory and New Spain, During the Years 1805-6-7. Two volumes. Ross and Haines, Minneapolis.

Cox, I. W.

1990 Field Survey and Archival Research for the Rosillo Creek Battleground Area, Southeast San Antonio, Texas. Archaeological Survey Report, No. 177, Center for Archaeological Research, The University of Texas at San Antonio.

Current, R. N., T. H. Williams, and F. Freidel

1979 American History: A Survey. Volume II: Since 1865. Fifth Edition, Alfred A. Knopf, New York.

de Alamazán, J. A. P.

1731 Report of the Survey of the Original Town Tract of San Fernando de Béxar. Spanish Materials from various sources, Barker History Center, Austin.

de Aviles, A.

1732 Carpeta de Correspondencia de la Provincias Internas por los Años de 1726 a 1731. Archivo General Nacional de Mexico, Volume 236:28. Richard Garay Collection, San Antonio.

Ellsworth, C. E.

1923 The Floods In Central Texas In September, 1921. Water Supply Paper 488 . Department of the Interior, United States Geological Survey. Government Printing Office, Washington, D. C.

Faulk, O. B.

1964 Last Years of Spanish Texas, 1778-1821. Morton, London.

Fehrenbach, T. R.

1968 Lone Star, A History of Texas and the Texans. Macmillan, Toronto.

1983 Lone Star, A History of Texas and the Texans. Macmillan, Toronto. 
Fox, A. A.

1992 Archaeological Investigations in Alamo Plaza, San Antonio, Bexar County, Texas, 1988 and 1989. Archaeological Survey Report, No. 205. Center for Archaeological Research, The University of Texas at San Antonio.

Galbraith, J. K.

1972 The Great Crash-1929. Houghton Mifflin, Boston.

Green, R. M. (editor)

1921 Memoirs of Mary Maverick. Alamo Printing, San Antonio.

Habig, M. A.

1968 San Antonio's Mission San José, State and National Historic Site, 1720-1968. Naylor, San Antonio.

Hatcher, M. A. (translator)

1919 Texas in 1820, by Juan Antonio Padilla. Southwestern Historical Quarterly 23:47-68.

Hoffman, F. L. (translator)

1935 Diary of the Alarcon Expedition into Texas, 1718-1719. Quivira Society Publications, Volume 5. Reprinted, Arno, New York.

Hoover, H. C.

1952 The Memoirs of Herbert Hoover: The Great Depression, 1929-1941. Macmillan, New York.

James, V. L.

1938 Frontier and Pioneer Recollections of Early Days in San Antonio and West Texas. Privately printed, Artes Gráficas, San Antonio.

John, E. A. H.

1975 Storms Brewed in Other Men's Worlds: Confrontations of Indians, Spanish and French in the Southwest, 1540-1795. Texas A\&M University Press, College Station.

La Fora, J. F.

1958 The Frontier of New Spain: Nicolas de la Fora's Description, 1766-68. Translated by Lawrence Kinnaird. The Quivira Society, Berkeley, California.

Leal, J. 0.

1986 Division of the Lands of the Canary Islanders in San Antonio. Bexar County Archives, San Antonio, Texas.

Nixon, P. I.

1936 A Century of Medicine in San Antonio. Privately published, San Antonio.

Ortiz, F. X.

1745 Visita de las Misiones lecha de orden Fr. Juan Fogueras. Division K, legajo 4, document no. 11. Archivo del Colegio de la Santa Cruz, Querétaro.

1756 Razón de la Visita de las Misiones de San Xavier y de las de San Antonio de Valero en la Prov. y Gobernación de Texas, Maio de 1756. Transcript, Library of the Daughters of The Republic of Texas, San Antonio. 
Quirarte, J.

1983 Letters From Governor Antonio Martinez to the Viceroy Juan Ruiz de Apodaca. Research Center for the Arts and Humanities, The University of Texas at San Antonio.

San Antonio Express [SAE]

1868 Railroad Excitement. 19 December.

1868 Big Train. 20 December .

1874 Meeting. 8 April.

1874 Proceedings. 13 April.

1876 The Alazan Ditch. 23 November.

1876 The New Ditch a Success. 24 November.

1877 The Grand Celebration. 20 February.

1877 San Antonio-Railroad City. 23 February.

1878 Local News and Gossip. 6 July.

1878 Doings of the City Dads. 10 July.

1881 City Council. 2 March.

1883 City Council. Walnut Street. 17 January.

1883 City Council. 21 March.

1883 Sewerage and Drainage. 30 August.

1883 City Council. 5 September.

1883 City Council. 19 September.

1884 Bolton's Baby Buried. 24 March.

1885 City Council. 1 February.

1885 City Council. 8 October.

1886 Municipal Matters. 16 February.

1887 Municipal Matters. 3 August.

1887 City Council Meeting. 9 August.

1887 The San Antonio River. 21 August.

1893 Mayor Shows His Hand. 10 February.

1893 It Is Mayor Paschal Now. 28 February.

1893 Plans for the Sewers. 17 August.

1893 On Burning The Garbage. 22 August.

1893 Appointments By The Mayor. 3 October.

1893 Wants Pay For The Furnaces. 22 November.

1893 Repairs Of The Hospital. 28 November.

1894 Gray's Sewage Report Arrives. 10 July.

1894 The Bond Election. 8 August.

1897 Brief Session Of The Council. 14 September.

1900 City Council In Session. 13 November.

1901 Sunset's New Depot. 2 April.

1901 Inspecting The Depot Site. 28 June.

1903 Aldermen Want News From The City Expert. 4 August.

1905 Bonham Street Navigable Stream. 27 June.

1906 Russi Solves The Drainage Question. 3 January.

1906 A. Biesenbach is Appointed City Clerk. 17 April.

1907 Sunset Depot In Ruins. 28 February.

1907 Mayor Plans To Reorganize The Garbage System. 21 July.

1911 City's Budget Will Be Ready By Thursday. 7 March.

1911 Railroad Needs Nine Additional Tracks In Yard. 14 March.

1913 Old Timers Recall Incidents of Big Floods of Early Days. 2 October. 
1917 British Liner California Sunk Without Warning. 8 February.

1917 U-Boat War Reaches Gigantic Proportions. 22 February.

1917 Plot To Embroil U. S. In War. 1 March.

1917 President Asks Congress To Declare State Of War Exists. 2 April.

1917 San Antonio To Have 60,000 Troops. 15 June.

1917 Another Aviation Field Near City For Government. 30 August.

1917 Brooks Killed At Kelly Field No. 2. 14 November.

1917 Brooks Field To Be Name Of New Aviation Ground. 11 December.

1918 Germany Gives Up. 11 November.

1918 City Placed Under Strict Quarantine to Check Epidemic. 10 December.

1918 City Council Making 13 December.

1919 San Antonio Has Three-Inch Rain Fall in 24 Hours. 22 July.

1919 Storm Strikes; Isolates Lower Coast. 15 September.

1919 Flood Puts River Up, But Damage to Property Slight. 17 October.

1921 Timely Showers Revive Ranges in Southwest Texas. 9 September.

1921 San Pedro Creek Tract Dangerous. 11 September.

1921 Flood Cannot Be Foretold; Can Be Prevented. 4 December.

1929 Plan to Beautify 'Big Bend' Meets Mayor's Approval. 27 June.

1929 Preliminary Steps Toward Creation of Miniature 'Old World Street' Along Big Bend Taken at Meeting. 29 June.

1929 Engineers Vote to Fight Ouster. 26 October.

1934 Abandoned Jobs to be Re-opened. 18 May.

1934 Old Levee Is Only Memory Of Once Busy Days On Austin Street. 22 July.

1935 Architect Tells of River Beauty. 1 October.

1936 River Improvements and Beautification Begins. 3 January.

1936 River Downtown to be Lighted. 8 April.

1939 River Beautification to Start a Ceremony Friday. 19 March.

1940 Lights and Music. 29 April.

1941 River Beautification Project Turned Over to City by WPA. 14 March.

1942 A New Parade Loop is Being Formed. 24 April.

San Antonio Herald

1868 San Antonio Valley Ditch. May 7.

San Antonio Light [SAL]

1903 Opening of Madre Ditch. 14 July.

1892 Wanted, A Business Council. November 25.

Schuetz, M.

1966 Historic Background of the Mission San Antonio de Valeró. Report No. 1. State Building Commission Archeological Program, Austin.

Steinfeldt, C.

1978 San Antonio Was: Seen Through a Magic Lantern. San Antonio Museum Association, San Antonio.

Tous, G. (translator)

1930a The Espinosa-Olivares-Aguirre Expedition of 1709. Preliminary Studies of the Texas Catholic Historical Society, I(III).

1930b Ramón Expedition: Espinosa's Diary of 1716. Preliminary Studies of the Texas Catholic Historical Society, I(IV). 
Turanza, J. P. (editor)

1961 Documentos para la Historia Eclesiástica y Civil del la Provincia de Texas o Nueva Philipinas, 1720-1779. Colección Chimalistac de Libros y Documentos Aceria la Nueva España, Madrid, Spain.

Valdéz, J.

1720 Report of Captain Juan Valdéz, March 13. In The San José Papers, Part I: 1719-1791, Fr. B. Leutenegger, translator, Fr. M. A. Habig, compiler and annotator. Old Spanish Missions Historical Research Library, San Antonio.

Viele, E. L.

1861 Handbook for Active Service, Containing Practical Instructions in Campaign Duties for the Use of Volunteers. D. Nostrand, reprinted Greenwood Press, New York, 1968.

Webb, W. P. (editor)

1952 The Handbook of Texas. Two volumes, The Texas State Historical Association, Austin.

Zunker, V. G.

1983 A Dream Come True: Robert Hugman and San Antonio's River Walk. Privately published, San Antonio. 


\title{
Chapter 3
}

\section{An Architectural Study}

\section{Introduction}

\author{
Anne A. Fox
}

The architectural firm of Andrew Perez Associates (APA) contracted with the Center for Archaeological Research (CAR) to do an architectural study of the area to be impacted by construction of the Alamodome and surrounding parking lots, which included 65 acres, or approximately 17 city blocks (Figure 1-1). Since total elimination of all standing structures would be necessary, APA was also asked to prepare a mitigation plan for any buildings identified as "HistoricalSignificant" by the Historic Resources Survey (City of San Antonio 1986), the only previous architectural study of this area. The result of the APA study is an illustrated report containing photographs of all houses and commercial and industrial buildings standing on the site in 1990 (Andrew Perez Associates 1990). Also included are record photographs of the facades and various architectural details of the Southern Pacific Railroad Passenger Depot and the Alamo Iron Works buildings, plus numerous interior shots of the shops showing interior construction and the machinery inside.

In 1991 APA conducted Historic American Buildings Survey (HABS) recording of two structures on the Alamodome site at the request of the Texas Historical Commission (THC) and the San Antonio Historic Preservation Officer. These detailed drawings were submitted to the THC. All the historic structure investigations, including the HABS recordings of the Griesenbeck-Roatzsch House and the Demazieres House and the Architectural Inventory and Assessment of the entire Alamodome site, were approved by the architecture staff of the THC (Denton to Lozano,
February 21, 1991, letter on file at CAR). The HABS documentation is on file in the archives of the THC. The original photographs and negatives used in the Architectural Inventory and Assessment are on file with the records of the Alamodome Project at CAR, along with two copies of that publication.

From thorough and valuable documentation by the APA, I have determined what can be learned in terms of architectural styles popular at various times, the implications these have for a general study of the settlement of an area of the city, and the changing ethnicity of a neighborhood. By comparing the architectural styles popular in this particular part of San Antonio with those recorded in a similar survey on the west side of the city, tentative conclusions can be proposed about the growth and development of San Antonio and the architectural preferences of its ordinary citizens. This subject has been essentially ignored by previous researchers, who have tended to concentrate on the architecture of the more wealthy citizens, such as that of the King William area (Burkholder 1973, 1976; Carson and McDonald 1986).

This chapter consists of three parts. The first section contains pertinent portions taken directly from the APA report. The second section takes the APA information and expands it in terms of analysis of house types, their dating, and how this information can be used for further analysis of neighborhoods. The final section contains information concerning the final disposition of standing structures in the Alamodome impact area. 


\section{Architectural Inventory and Assessment Andrew Perez Associates}

\section{Introduction}

This report documents the architectural and urban character of the Alamodome site at the time of its acquisition by VIA, and prior to its clearing to make way for construction of the new facility. The report initiates a detailed descriptive record of the site, to answer future inquiries about its character prior to the construction of the Alamodome, and to encourage further documentation. It is not an attempt to analyze the social matrix, current or historical, of either the study area or its surroundings.

Traditional techniques of investigation were employed to collect and ascertain information. These techniques include field notes, photographs, archival research, and oral history interviews.

\section{Urban Geometry and Planning}

The lands of the study area were subdivided and incorporated into the city as provided by the Plat of 1842-1860 (Figure 1-2). This plat established the street grid that existed at the inception of the project, with the following exceptions.

1) The former Santa Clara Street, which originally ran southwest from the intersection of Galveston Street and the Southern Pacific tracks, was closed in two phases. In 1925 it was closed between that point and the intersection of Hoefgen and Montana. At the same time or later, Hoefgen was extended north of Montana to restore a connection to the Southern Pacific depot. West of Hoefgen, Santa Clara was closed when IH-37 was built in 1967, to allow the extension of Montana Street under IH-37 to connect to Market Street.

2) Pauley (now Pablo) Alley was added in 1877.

3) Galveston Street west of Hoefgen Street, and Gonzales east of Hoefgen no longer exist.
Although Galveston east of Hoefgen is still a platted street, physically it has been merged with the Southern Pacific passenger depot site.

4) Eda Street was added about 1897 , and renamed Wells Street in 1915.

5) Runge Street was platted in 1924 to accommodate the houses that had previously been built along it.

6) The former Walnut Street straddles the Southern Pacific tracks and no longer exists except as a legal right-of-way.

\section{Residential Design And Construction}

\section{Victorian}

This term primarily refers to large, elaborate wood houses of the late-nineteenth and early twentieth centuries, typically two or more stories with a steep, complex roof and asymmetrical massing. However, Victorian characteristics appear in modest frame and brick houses built in the study area until around 1915 .

The signature of the Victorian-influenced house is the T- or L-shaped floor plan, one room thick and with a wing extending forward on one side of a shed-roofed porch. The kitchen is at the rear corner. On the ideally oriented site, this corner faces the northwest so that southeast breezes will carry the heat away from the interior during the summer, and north winds will drive it through the house during the winter.

The front of the extended wing is often octagonal or even semicircular in plan (Figure 3-1). The roof pitch is close to 12-on-12 (45 degrees) with a narrow overhang, except at the corners of an octagonal room, where the roof's function as a cover or lid may be theatrically exaggerated (124 Nevada). Porches are attached sheds, often with the floor not built up to the level of the interior. Windows are much taller than 


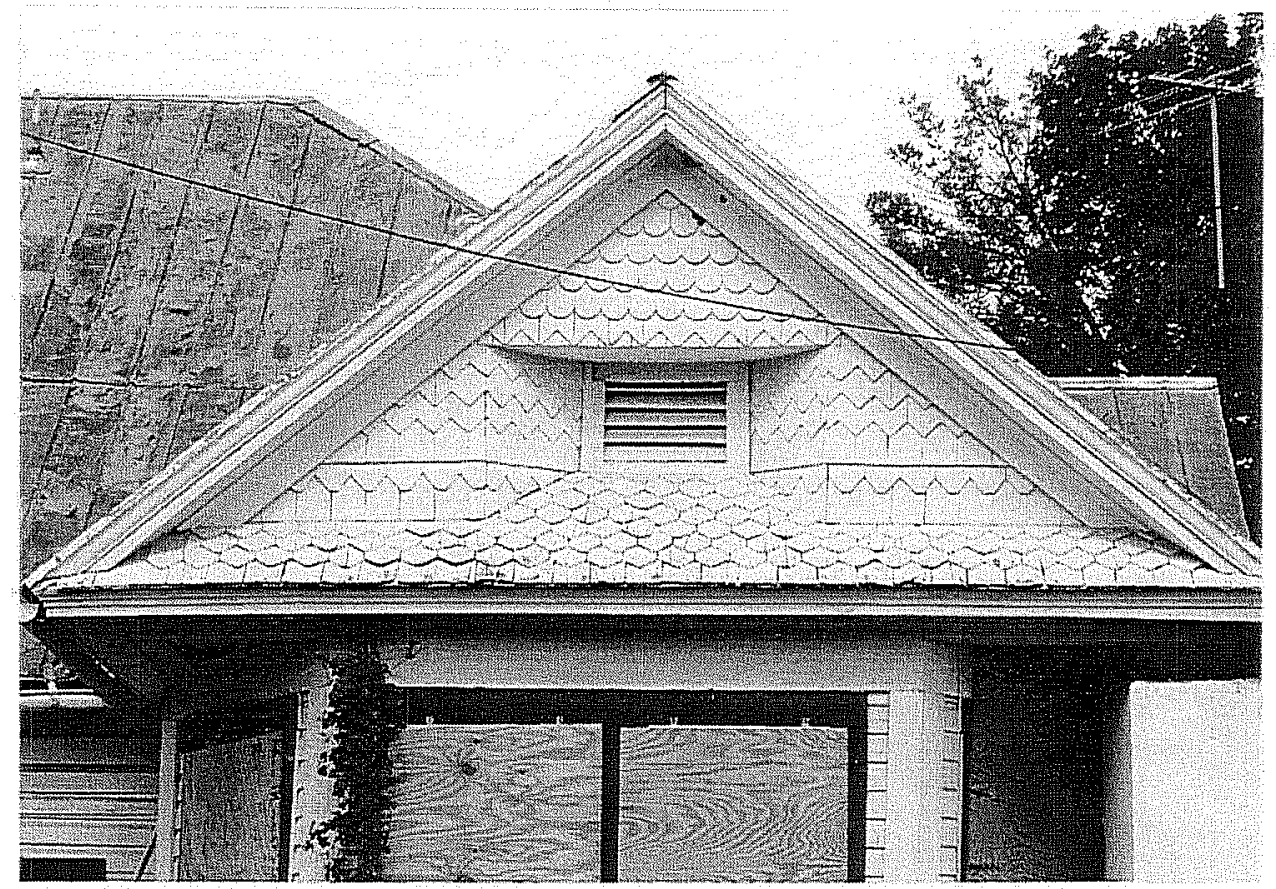

Figure 3-1. Extended wing of a Victorian structure (603 or 607 Hoefgen St.) APA 1990.

they are wide, and the ceiling height is usually $10 \mathrm{ft}$ or more. Among the basic ornamental devices are shingled gable ends and decorative window screens. Most of the Victorian houses now have plain wood or wrought-iron columns supporting the front porches; almost certainly these are replacements for originals that were chamfered (beveled) or turned.

All except one of the Victorian-period houses in the study area are wood frame with wood siding. The exception is 123 Nevada, which is brick. All visible foundations are directly buried cedar posts.

\section{Bungalow}

The term describes a style of detailing and composition in wood-stud tract houses that emerged in California early in the twentieth century. The bungalow is a simplification for mass consumption of the "craftsman" style exemplified by the residential work of Bernard Maybeck and the Greene brothers. Craftsman houses are a variant of the "prairie school" style of Frank Lloyd Wright and others in the Midwest. The entire trend was influenced by the "shingle" style of the latter nineteenth century, and by traditional Japanese architecture, with which American architects were becoming familiar around 1900.

The bungalow style accentuates the spread and canopy of the roof structure, with a relative de-emphasis of the wall as a simple wood frame. Houses of this style are usually one story and wrapped in shingles, stucco, or milled siding. The foundation may have battered skirting to match the siding. The roof pitch and ceiling height are lower than was usual in the Victorian house; typically the porch is integrated into the roof structure (Figure 3-2) and set into the plan. The front elevation is usually asymmetrical, although without the forward-

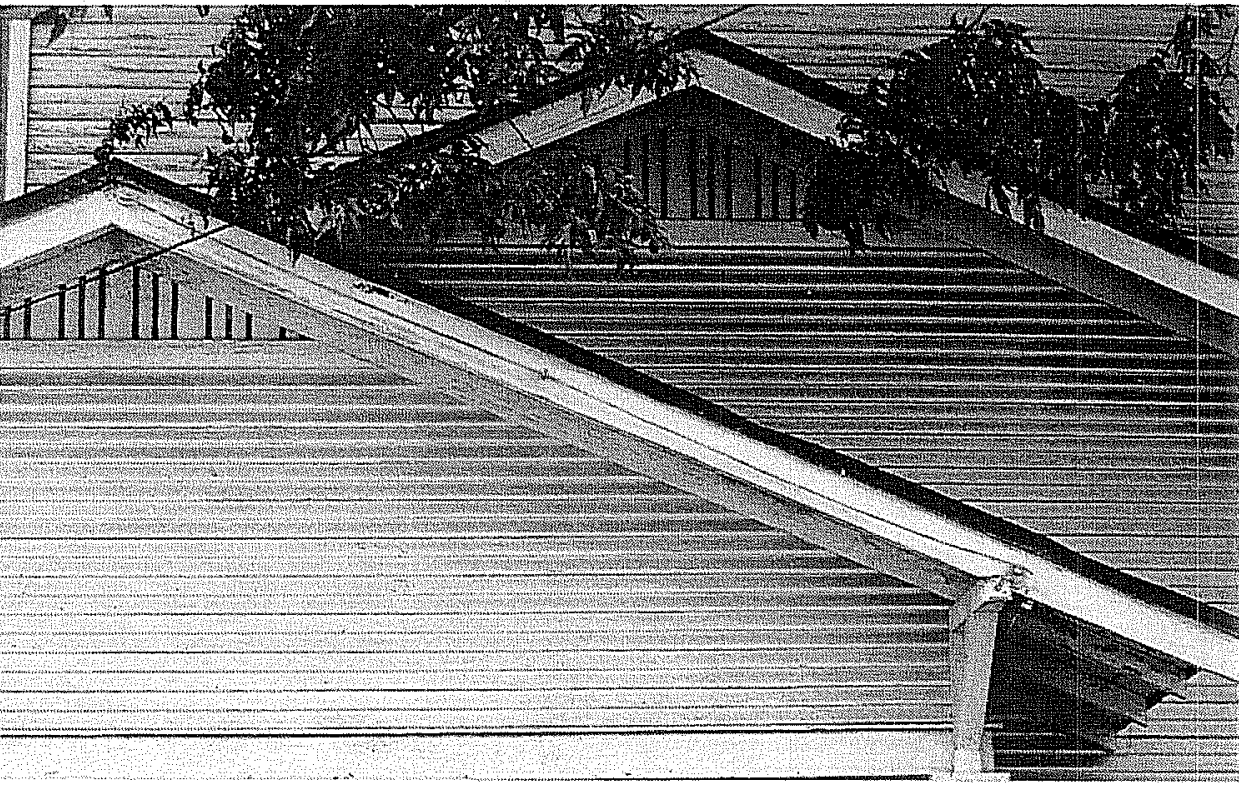

Figure 3-2. 419 Cherry St. APA 1990. 
thrusting wing characteristic of Victorian. Except in the simplest examples, there are multiple gables, with the main gable normally longitudinal. Often a second embedded gable covers the porch, and the front gable end is where some of the most characteristic detailing occurs.

The eaves are open, and visible rafter tails extend to the edge of the roof. The roof overhangs the gable ends and is often supported on bracketed beam ends. Elements such as doors, windows, and gable-end vents

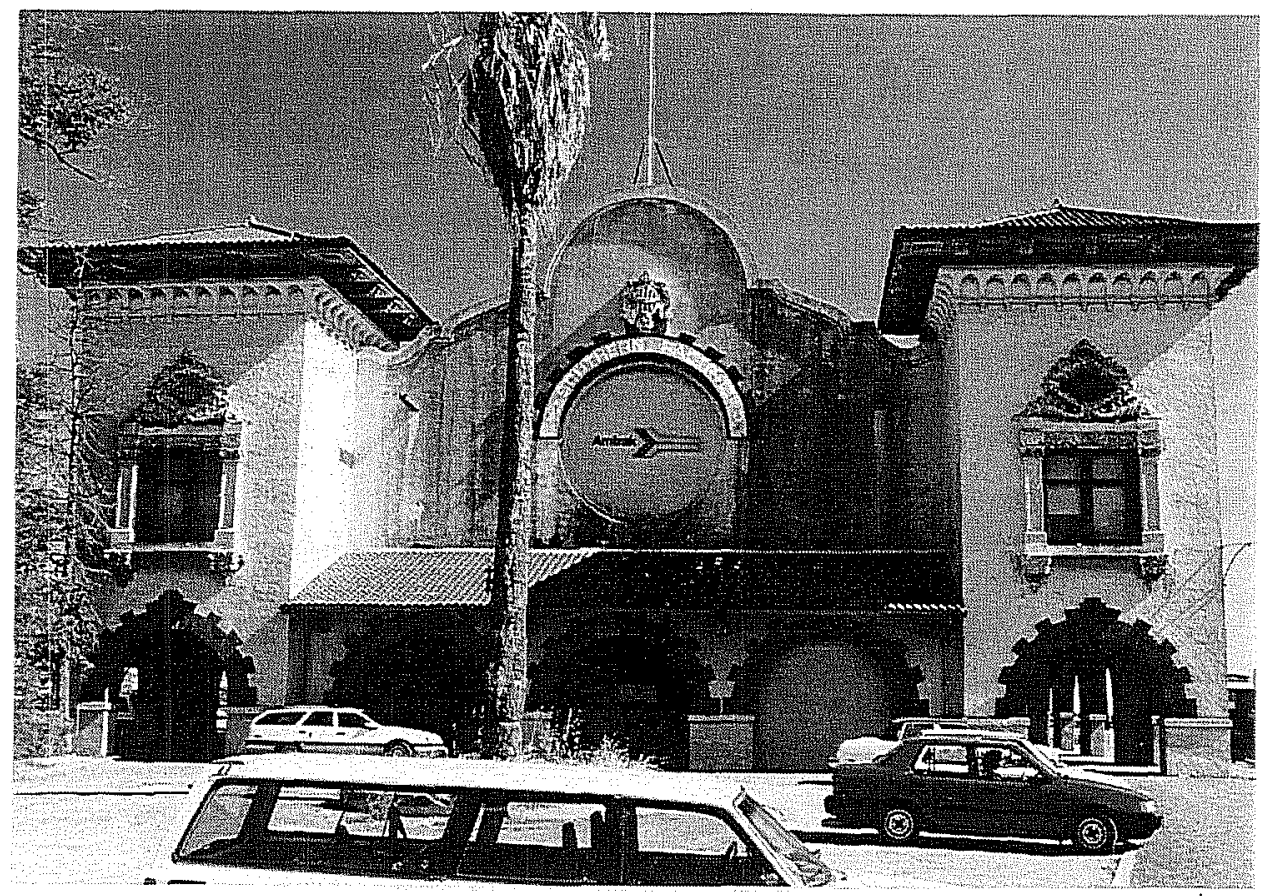

Figure 3-3. Southern Pacific Railroad

Station, front facade. APA 1990. are compositionally integrated with the structure rather than being isolated as figures punched into a plane surface. In the study area, most of the houses are architecturally minimal-419 Cherry Street (Figure $3-2$ ) is the most detailed example of bungalow influences.

\section{Non-Residential Structures}

Two distinctive groups of non-residential buildings within the study area merit individual attention: the Southern Pacific Railroad Depot and the Alamo Iron Works complex.

\section{The Railroad Depot (Figures 3-3 and 3-4) (1174 Commerce Street)}

This site was originally acquired for a passenger depot by the Galveston, Harrisburg and San Antonio Railroad, forerunner of the Southern Pacific Railroad. The architect for the building was D. J. Patterson, who was employed by the Southern Pacific Railroad in the San Francisco offices.

Figure 3-4. Southerm Pacific Railroad Station, west facade. APA 1990.

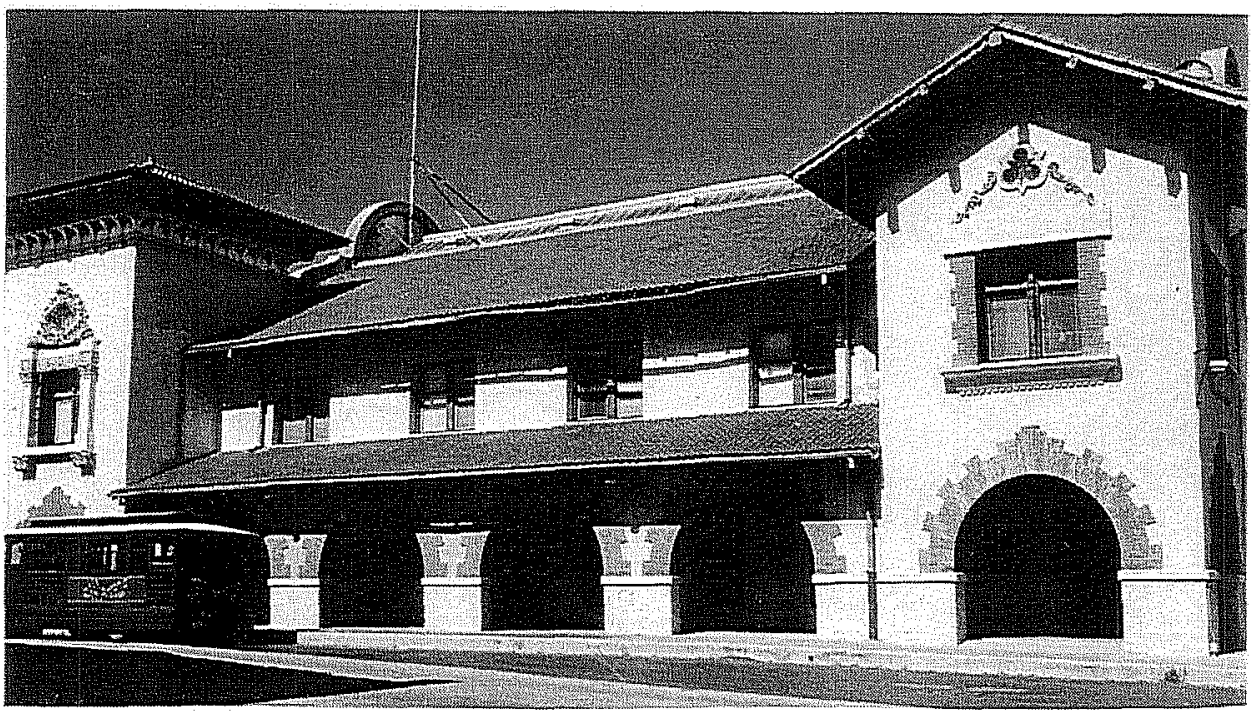


The depot, part of a series of such buildings intended to give the railroad a unified Southwestern architectural image, opened in 1903. Its design is flamboyant Spanish colonial, with some dramatically ornate details and just a touch of Chinese pagoda in the roofs of the northeast and northwest corner towers.

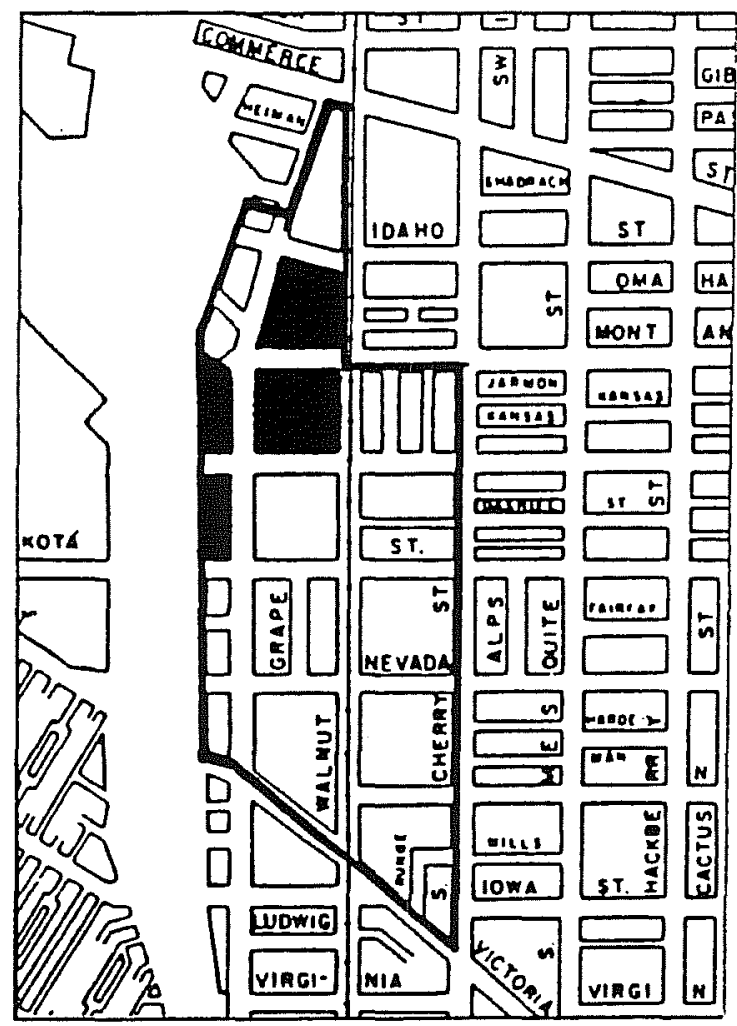

Alamo Iron Works (Figures 3-5 and 3-6)

Corporate Office Building

(101 Montana Street) (Figure 3-6)

The present office block-four stories and a semi-basement-encloses a previous building that had a smaller footprint. As the company grew, it periodically expanded the existing structure, including an addition that extends into the former right-of-way of Santa Clara Street following that street's closure.
Figure 3-5. Alamo Iron Works property (darkened) within the Alamodome Project area.

Figure 3-6. Alamo Iron Works,

Corporate Office Building.

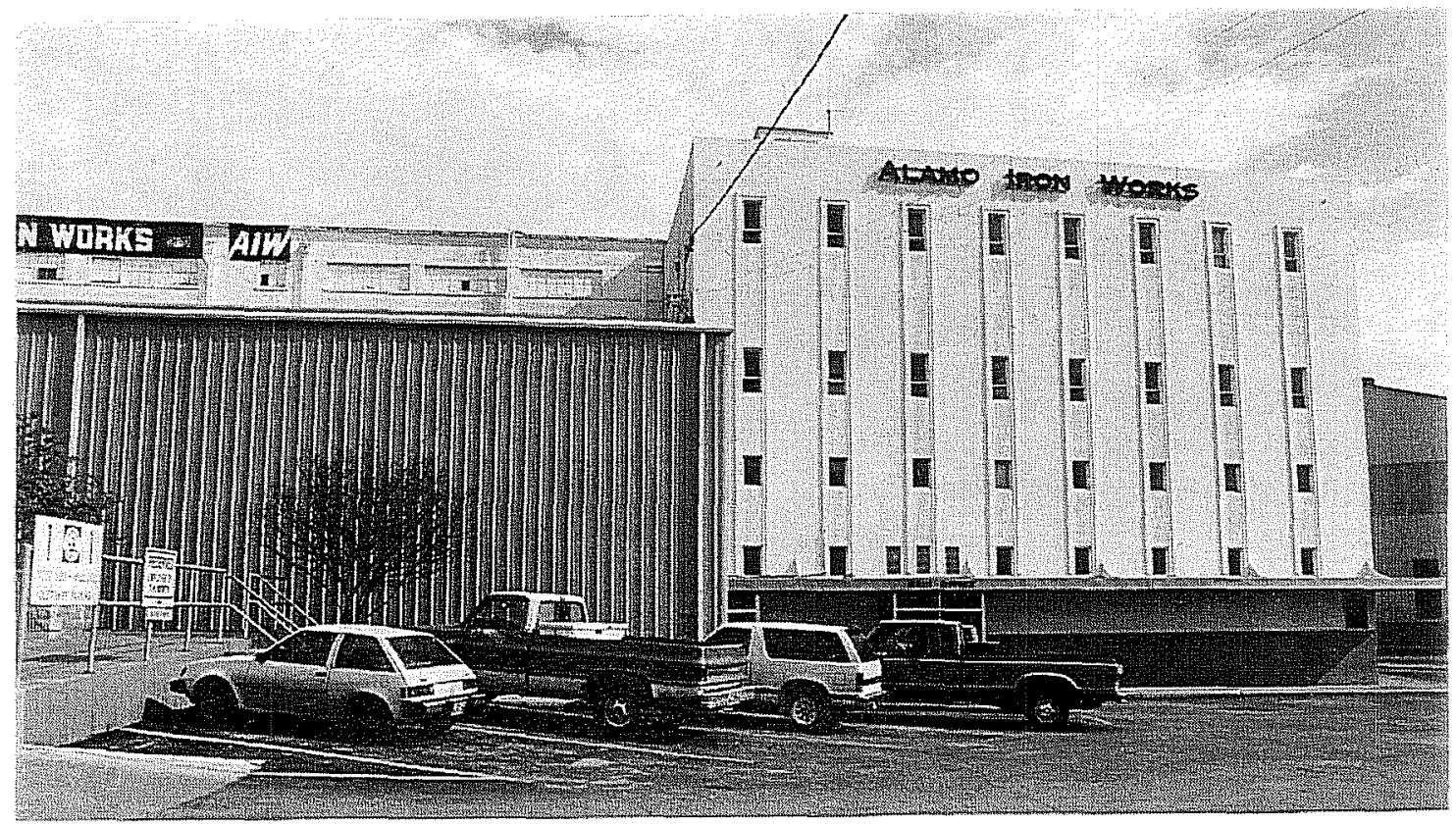


The front wing housing the company offices is an austere stucco box with punched windows, highlighted by surrounding panels and a Moderne suspended canopy around the base. The canopy casts a continuous shadow that visually disconnects the monolithic stucco facade from the ground and makes it slightly surreal. The skewed floor plan multiplies the effect: note the front (west) wall and the northwest wall meet at a 120 degree angle, but there is no architectural detail at the corner to give the game away.

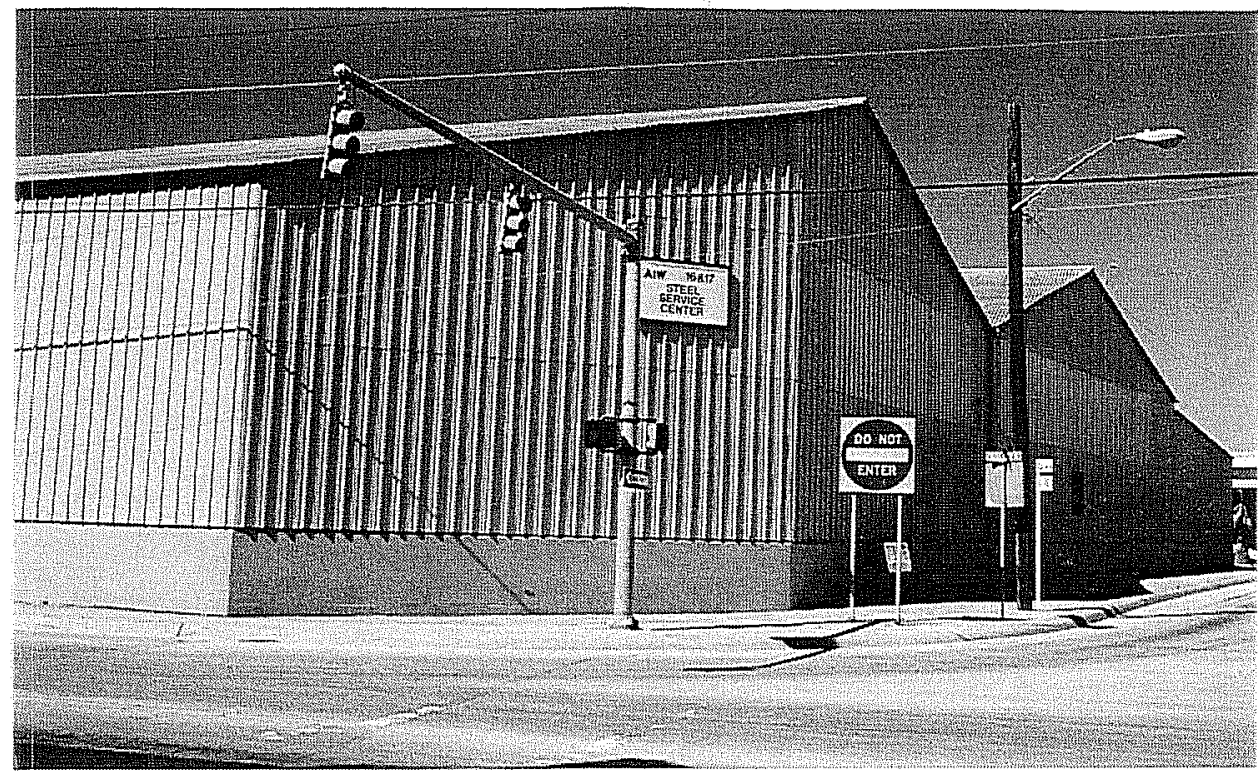

Steel Service Center (Figures 3-7 and 3-8) (319-323 Hoefgen)

The Steel Service Center is a custom-designed, all-steel, one-story industrial building covered by two parallel gable roofs. Exterior walls follow the property line on the north, east, and west sides; the building has an open cantilevered canopy on the south facade along the former Wyoming Street.
Figure 3-7. Steel Service Center, built during the 1960s.
Figure 3-8. Steel Service Center, built during the 1960 s.

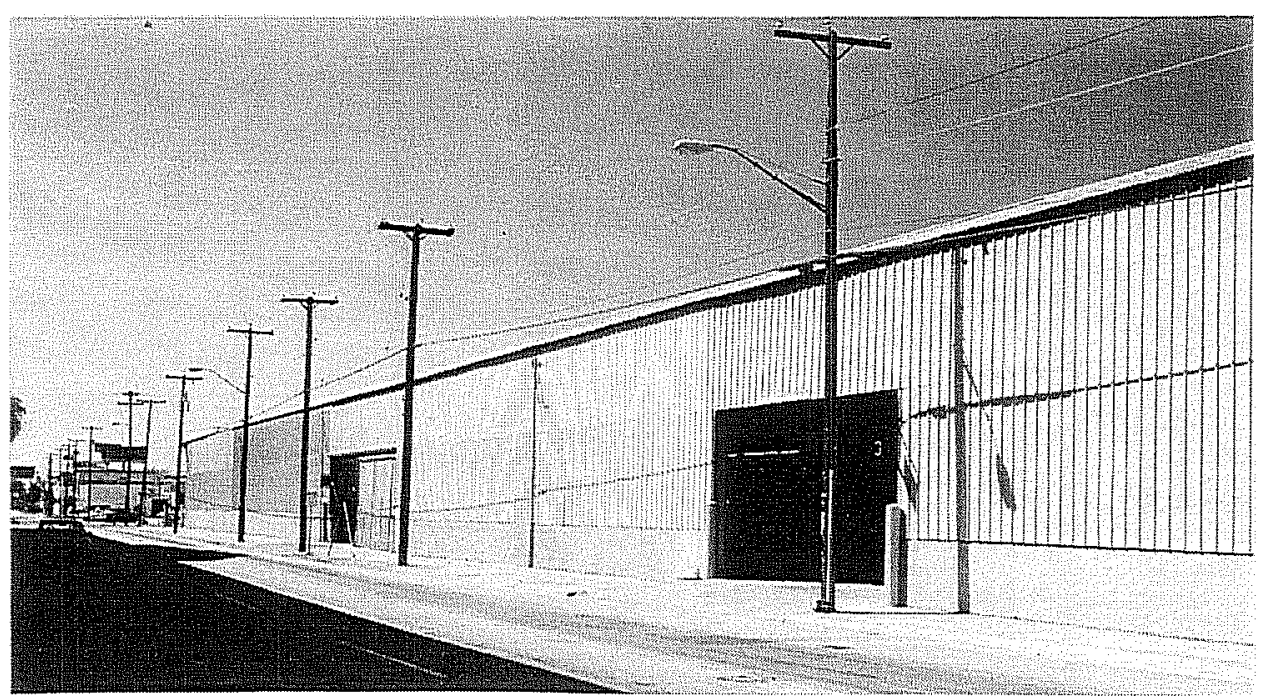


Alamo Iron Works Buildings 4-6, 25-27

(Figures 3-9 and 3-10)

(102-106 Montana)

One-story and two-story steel- and concrete-framed shop buildings have been added over the years to reach the current site coverage of nearly 100 percent. The collection of structures displays a variety of solutions to issues of medium-span industrial framing, daylighting, and ventilation. It also reflects the evolution of construction costs and design practices over the years.
Figure 3-9. Alamo Iron Works, the oldest existing shops.

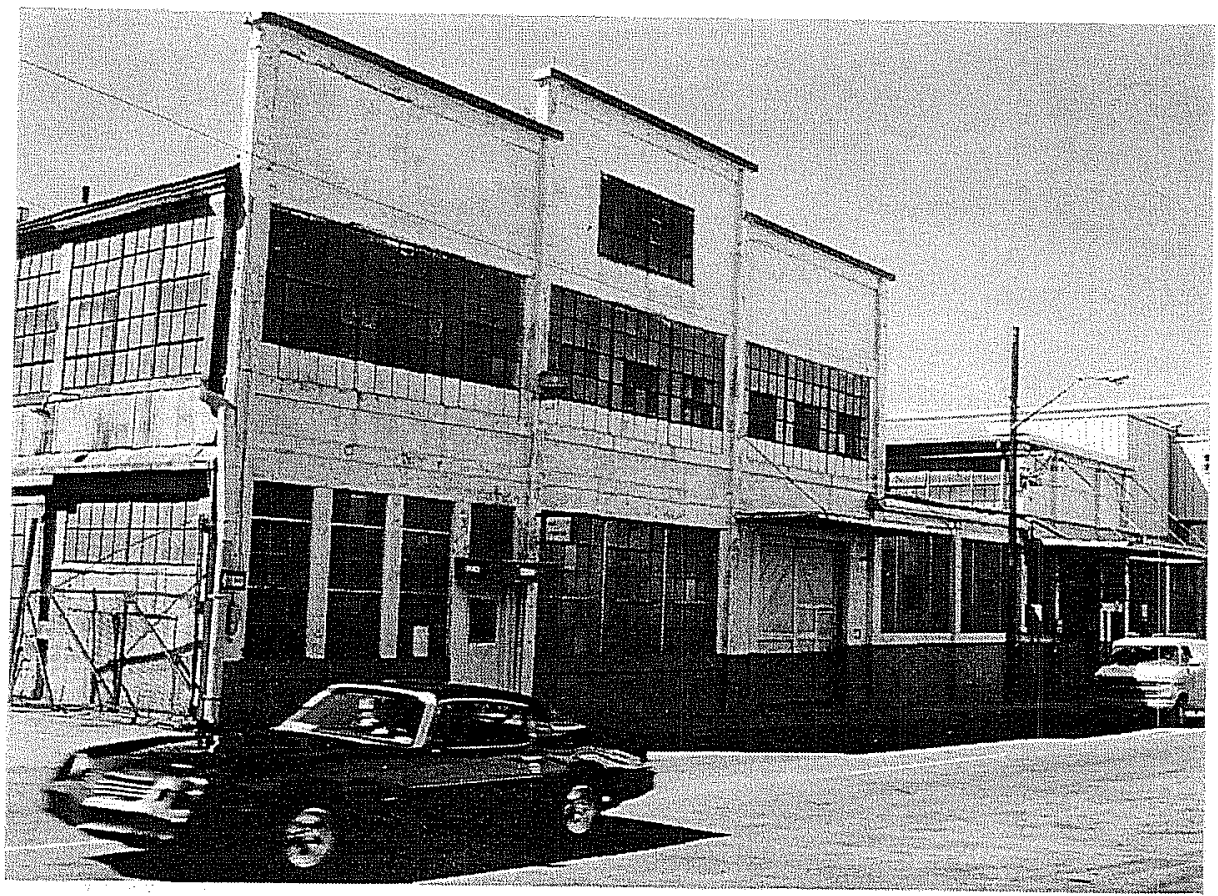

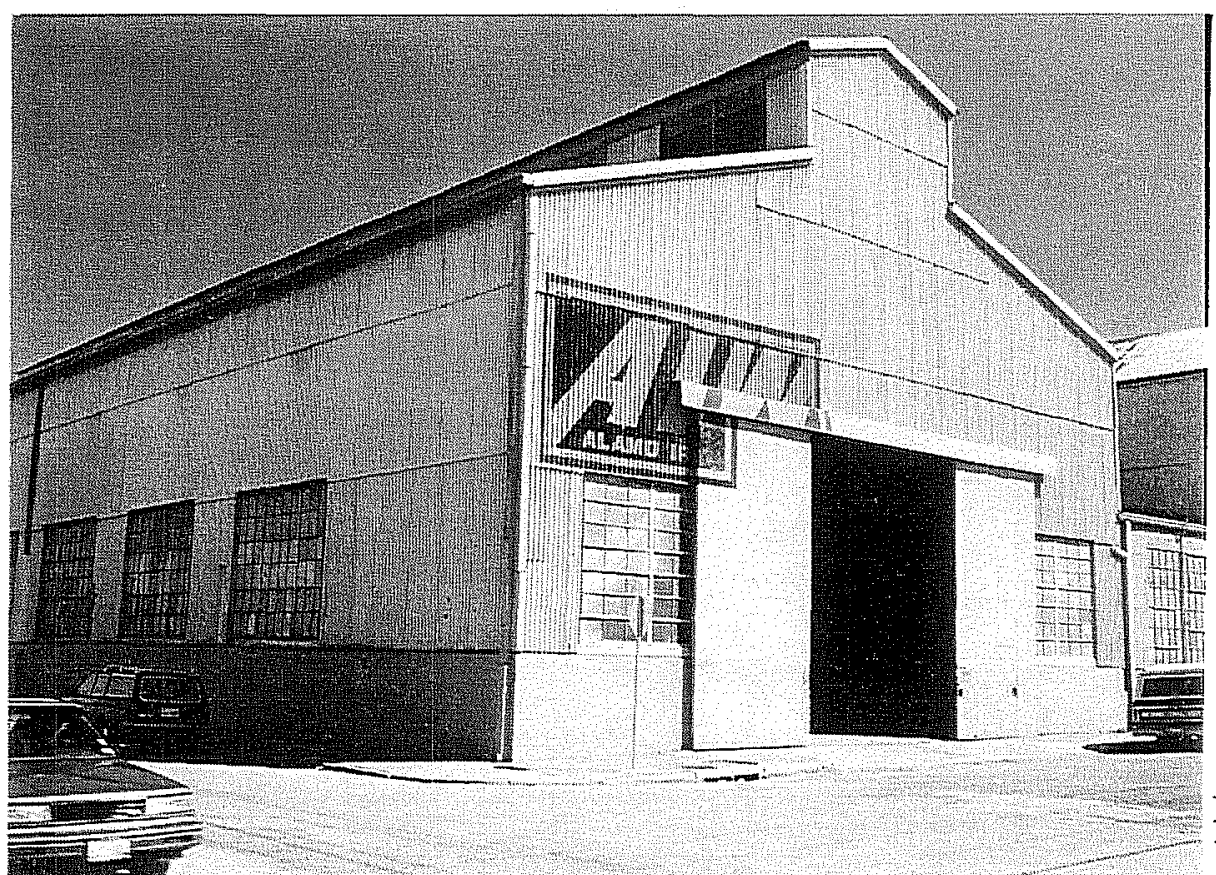

Figure 3-10. Alamo Iron Works shops. 
Main Warehouse and Re-bar Fabrication Shop

(Figures 3-11 and 3-12)

(201-133 Wells Street)

The site is almost completely covered by a pre-engineered steel building with three east-west gables. The southernmost module has an open full-width canopy on the east elevation.

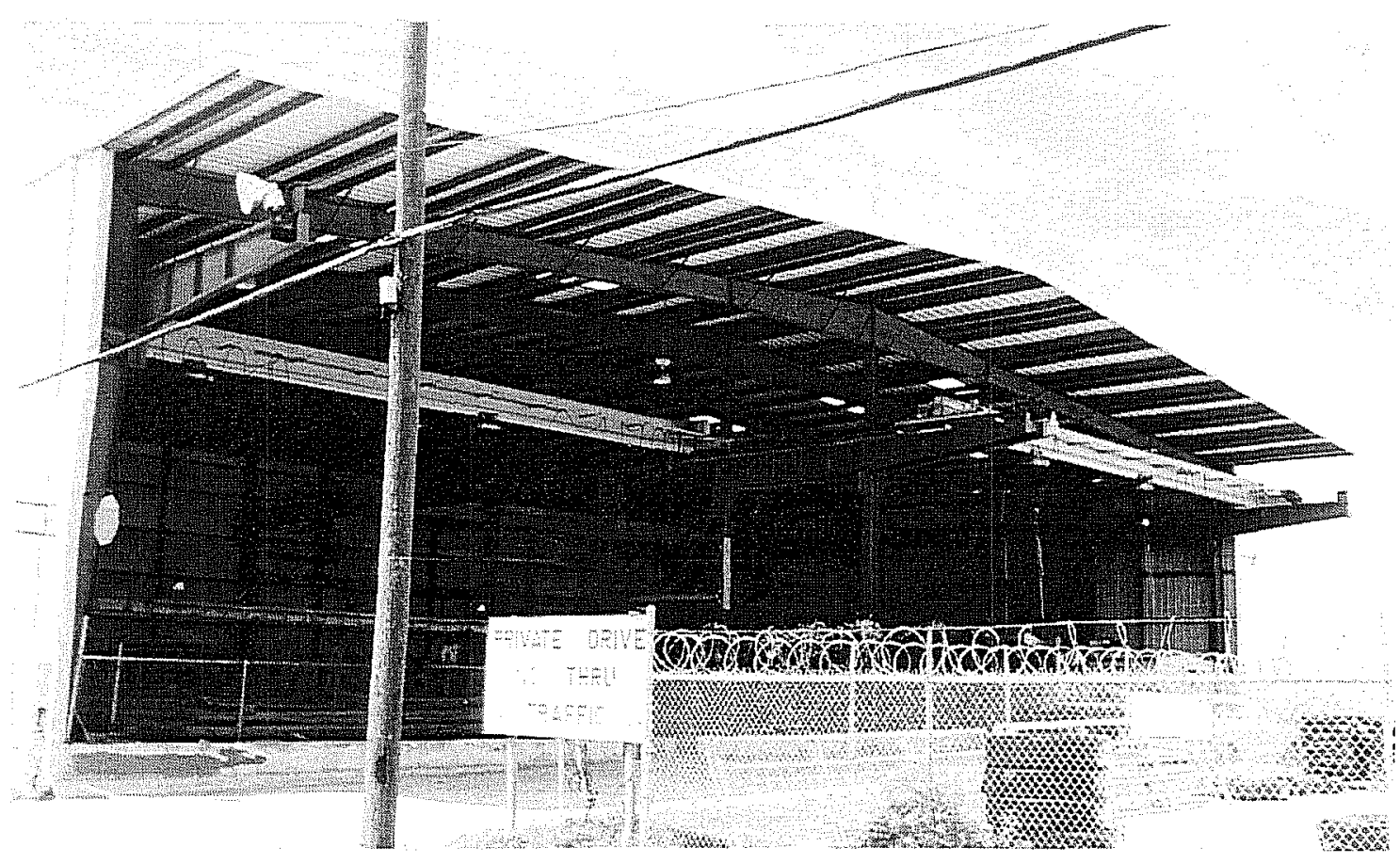

Figure 3-11. Main Warehouse and Re-bar Fabrication Shop, south facade.

Figure 3-12. Main Warehouse and Re-bar Fabrication Shop, north facade.

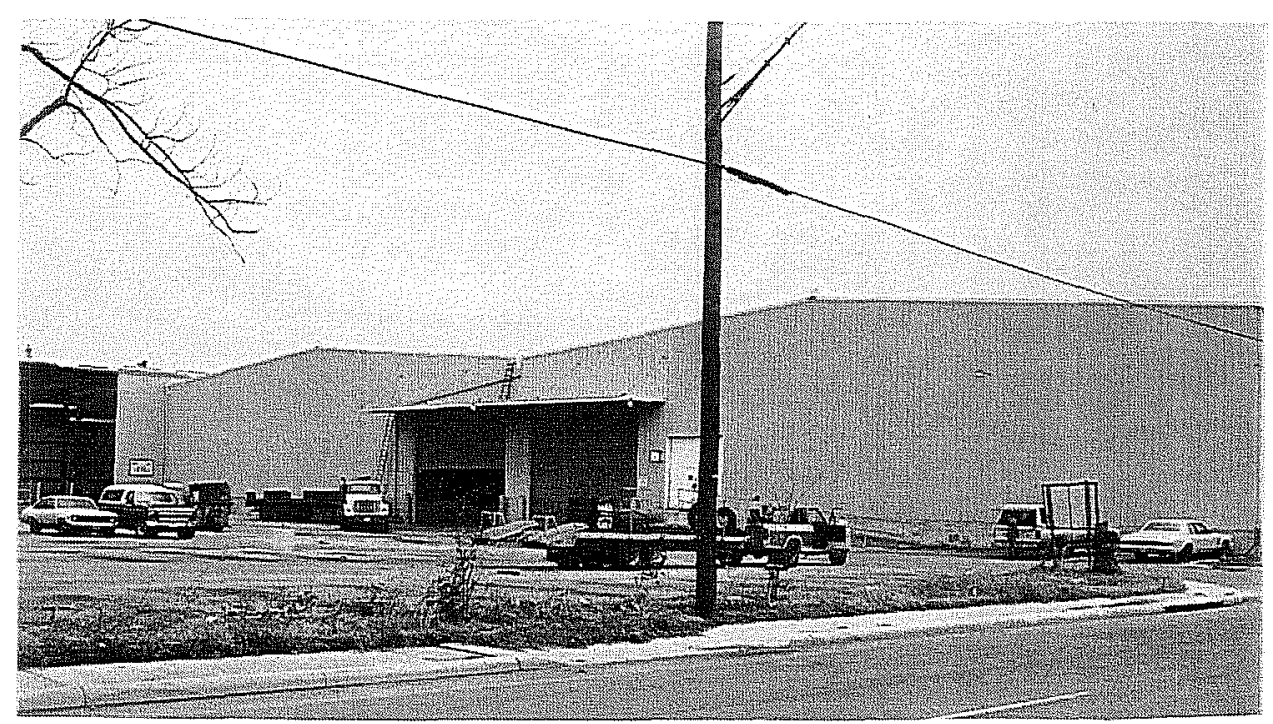




\section{Domestic Architecture in San Antonio}

\section{Anne A. Fox}

McAlester and McAlester (1986) divide domestic buildings into two categories: folk houses and styled houses. Folk houses were built by non-professional builders or by the intended occupants. These are simple structures intended for shelter with no particular concern for style. Their size, shape, and appearance, then, are based on the limitations of the available materials and on the traditions brought to the task by the builder. Styled houses, on the other hand, were built with at least a minimal attempt to be fashionable and reflect in some of their details the architectural style popular at the time they were built. Later additions are likely to reflect architectural styles in vogue at the time of the alteration, making analysis of the house type confusing. An amusing commentary on this problem is found in Kniffen's survey of Louisiana house types (1962:158),

Neither houses nor other cultural forms can be classified in a manner exactly analogous to that used by biologists. The biologist never finds the tail of a lion grafted to the body of a cow; the classifier of cultural forms has no such assurance. He must judiciously generalize, and he can never be completely objective.

\section{Folk Houses}

Drury Alexander (1966:3) remarks on the strong influence the cultural origins of the home builders and owners of Texas had on houses built before 1900 . Taking this into consideration, one might expect to find a strong German and Spanish-Mexican architectural influence in San Antonio until 1900. The gradual changes in the composition of the San Antonio population allow us to observe whether Alexander's suggestion holds true for this area.

Descriptions of eighteenth- and early nineteenthcentury San Antonio stress that the plazas were surrounded by low, flat-roofed buildings of soft limestone or adobe. Also very much in evidence were small jacales with walls made of upright posts plastered with mud and roofed with thatch. Both of these vernacular building types came directly from México (see West 1974) with the first settlers.

The first European and American men began to arrive in the 1830 s. They generally married into Spanish families and tended to live in whatever local housing was available. In 1838 Mary Maverick remarked that her family was the only American family in town (Green 1952:77). The Mavericks rented vernacular houses on and near Main Plaza during their first years in San Antonio. By 1841 the number of American women had increased to five. All buildings were still adobes and jacales (Everett 1975:20), but the influx of Germans and other central Europeans in the 1840s gradually changed the town's appearance. An observer in 1857 remarked on the number of gable-roofed houses of "fresh square-cut blocks of creamy-white limestone" (Olmsted 1857:149); this style was more typical of European architecture, but used traditional Mexican masonry materials and techniques. They represented an interesting amalgamation of influences from Mexican and European architecture. Terry Jordan notes this same "overlap, mixing, and hybridization" (1980:1) in the border region. Due to the absence of suitable timber, lumber for roof and porch framing was hauled by freight wagons from Bastrop (Olmsted 1857:156) or by ox carts from ships unloading at Matagorda Bay (Sturmberg 1920:114). A horse-powered sawmill, opened in Bandera in 1852 (James 1938:21), began to turn out shingles for the low-pitched roofs of these small "settlement saltbox" houses, which were often "long and low and narrow, of a single story, and but one step from the ground" (Spofford 1976:22). A few of these houses are still preserved in the downtown area (Figure 3-13); however, most have been altered by the additions and remodeling required by spatial demands of a more modern lifestyle. 


\section{Styled Houses}

The arrival of the Galveston, Harrisburg and San Antonio Railroad in February 1877 brought new materials and architectural ideas to the area. The price of lumber for construction of houses suddenly came within the reach of aspiring homeowners. Lumber yards sprang up overnight, and an influx of Anglo-American entrepreneurs spurred the home building business as suburban development began to surround the city. The era of styled housing had arrived.

Heavy woodworking machinery

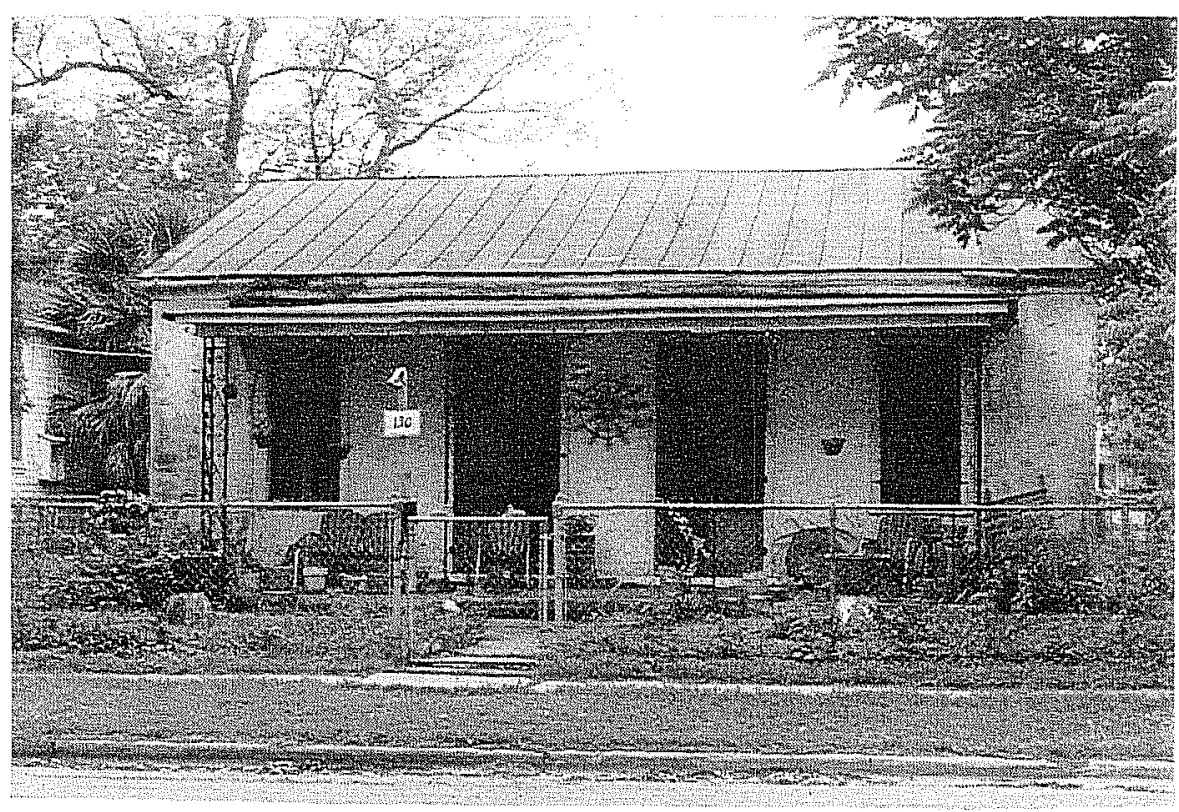

Figure 3-13. Settlement saltbox house, 130 Lavaca Street. could now be brought in and installed, allowing inexpensive Victorian detailing (McAlester and McAlester 1986:310). In some cases, earlier folk houses in the older parts of town were embellished with new Victorian porches and trim. A rapid growth in population in the last two decades of the nineteenth century resulted in streets of new frame houses occupied by workers in the downtown businesses and surrounding industries on the outskirts. Trolleys, at first horse-drawn then later run by electricity, allowed workers to live farther away from their jobs. This rapid spread of the city has been dramatically documented by Augustus Koch in his bird's-eye drawings of San Antonio in 1873 and 1886 (Figures 3-14 and 3-15).

Along with cheap lumber and woodworking machinery came new visions of what a house should look like. The simple one- or two-room settlement saltbox house with its side-gabled roof parallel to the street and a porch across the front gradually went out of fashion as people were exposed to new architectural designs from New Orleans and the Eastern United States. Varied room arrangements, changes in roof lines, and added Victorian details allowed the construction of a block or more of houses that were essentially the same size and price, but appeared to be individually designed. For purposes of analysis, these houses have been divided loosely into types by various authors (Blumenson 1977;

Gottried and Jennings 1985; Kniffen 1962; McAlester and McAlester 1986). McAlester and McAlester (1986) group all these under the term Folk Victorian. In this study, the late-nineteenth to early twentiethcentury-styled houses have been divided into the following types (Figure 3-16).

\section{Hall and Parlor}

These one-story frame houses with sideward-facing gables, two rooms wide and one room deep, are actually a traditional British folk form (McAlester and McAlester 1986:94) as well as being indigenous to the San Antonio area where their basic design comes from the settlement saltbox as described above. These houses were often expanded in size by adding a lean-to on the rear.

\section{Gabled or Plains Cottage}

This house type assumes its shape from the intersection of roof gables, forming an L- or T-shaped plan. The entrance is from a porch "nestled into the ell" (Gottfried and Jennings 1985:182). Variety in design and ornamentation allowed construction of many such houses on a block, each of which was slightly different 


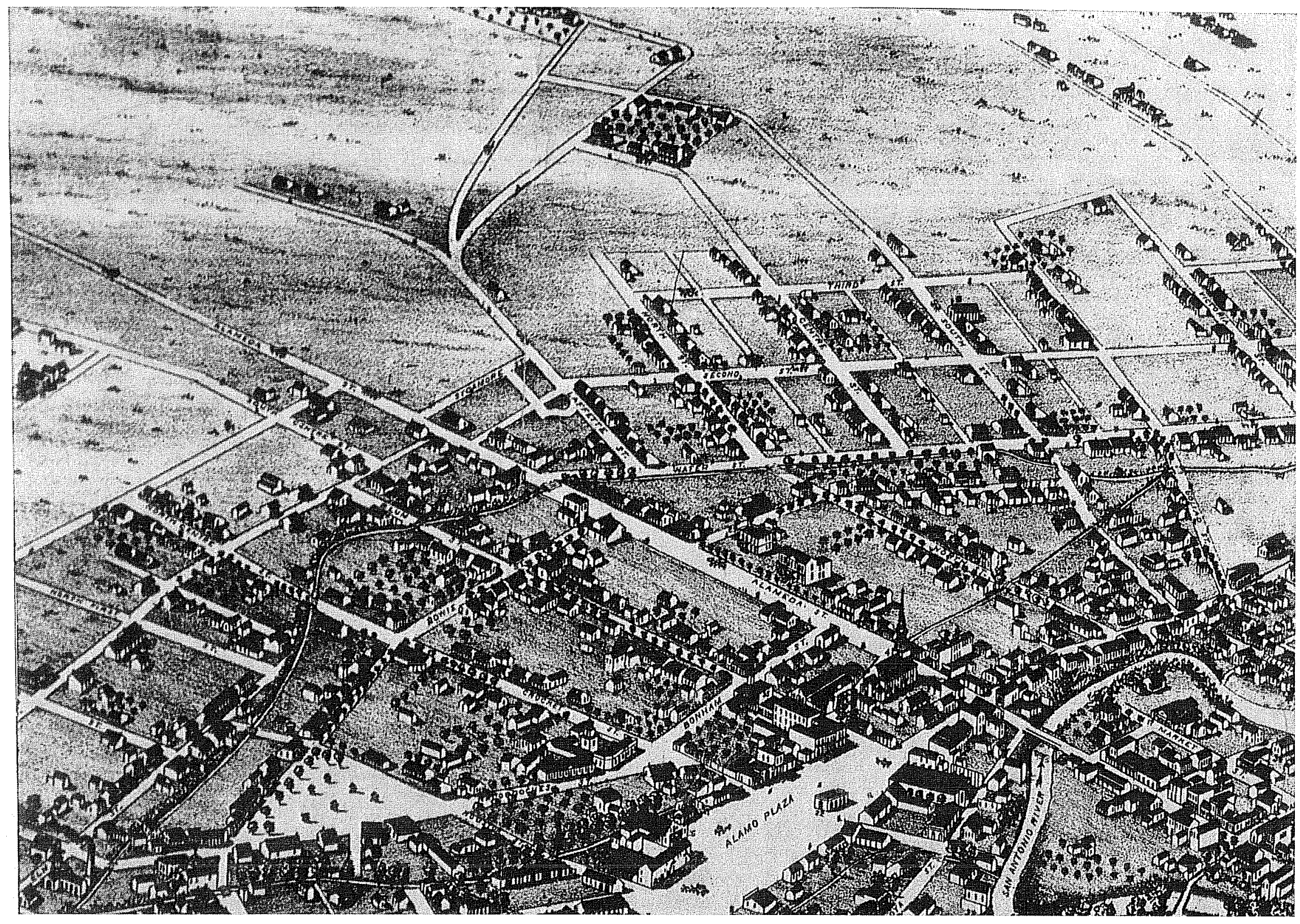

Figure 3-14. Detail of Augustus Koch's Bird's Eye View of the City of San Antonio, 1873. Looking south. 


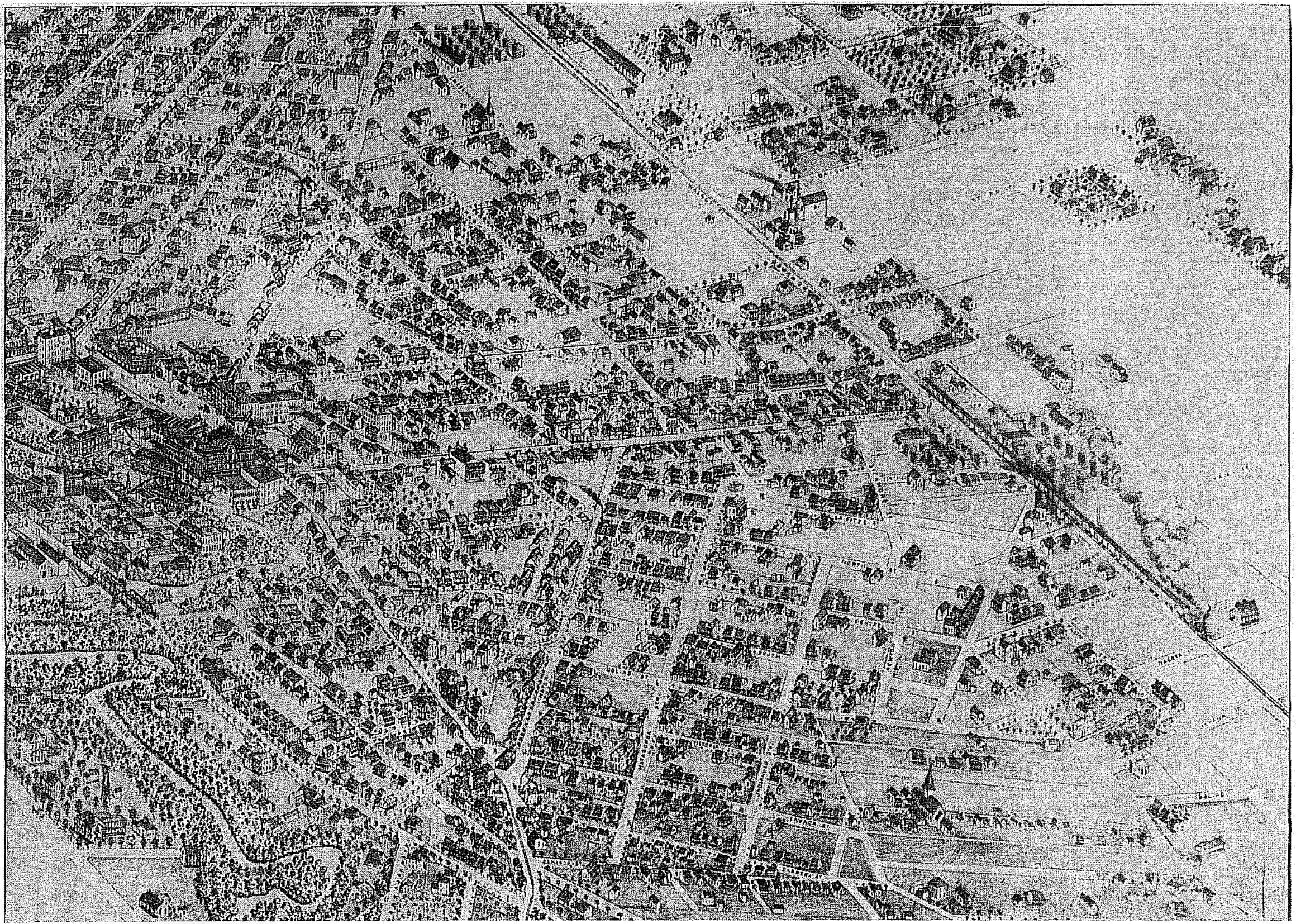

Figure 3-15. Detail of Augustus Koch's Bird's Eye View of San Antonio, 1886. Looking north. 

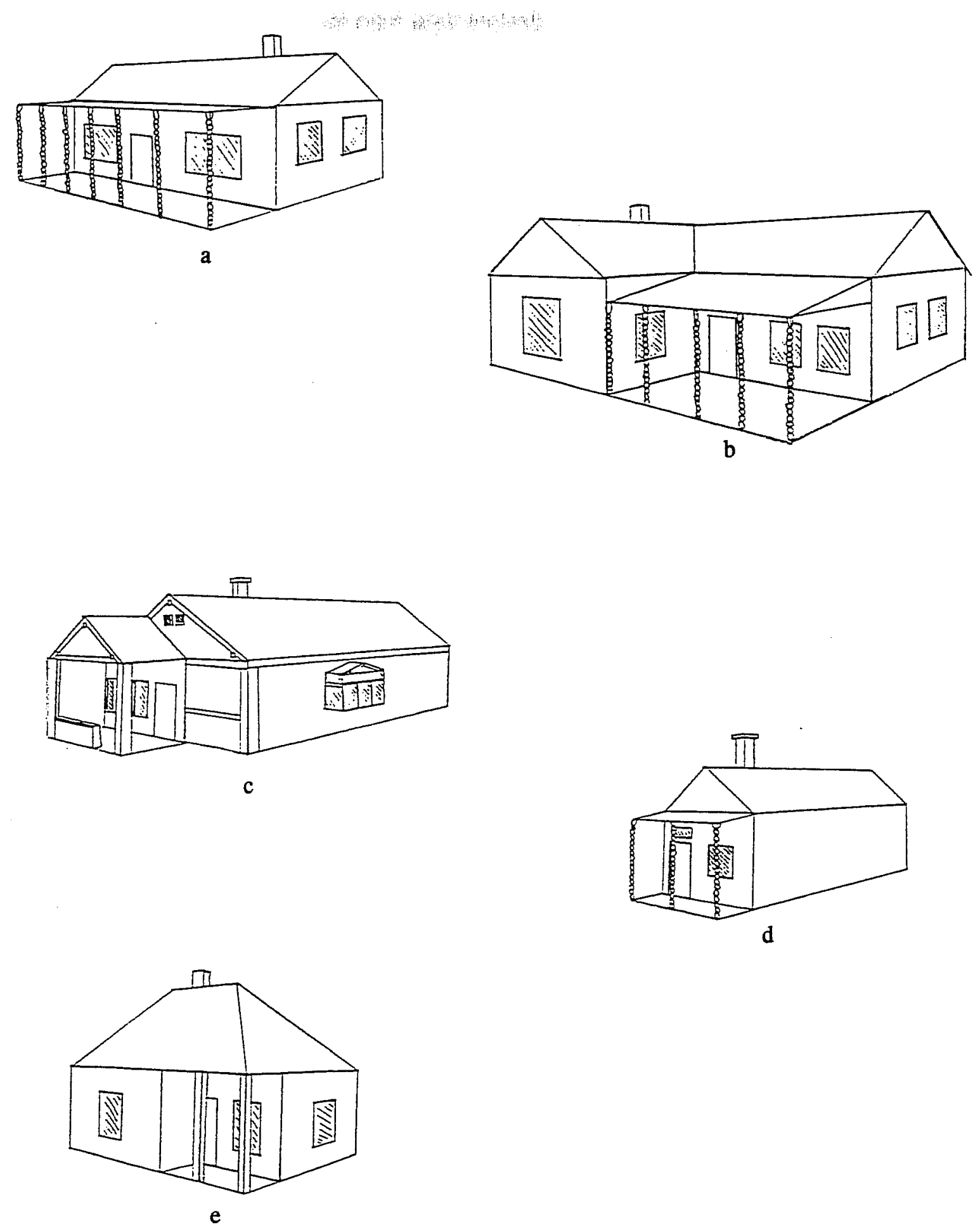

Figure 3-16. Diagrammetric sketches of house types in the Alamodome area. a. hall and parlor; b. gabled or plains cottage; c. bungalow or front-gabled roof; d. shotgun; e. pyramidal roof. 
in appearance. This type preceded the twentiethcentury bungalow.

\section{Bungalow or Front-Gabled Roof}

This one-story house is two rooms wide, with a gently pitched roof, the gable of which faces the street. Often a separate gable covers a front porch, of which the supporting piers may be battered. The rafters and roof beams can extend beyond the wall and roof. The type originated in California at the end of the nineteenth century. Houses of this type were popular between 1895 and 1915 (Gottfried and Jennings 1985:216). Occasionally, half the porch is enclosed in order to have more interior space. In these cases, a bay window or a triple window is often set into this addition. The porch then becomes an indentation or cutaway, giving the appearance that it is carved out of the main block of the house (Gottfried and Jennings 1985:220).

\section{Shotgun}

This front-gabled-roof house is one room wide. The style was common in New England during the early nineteenth century and followed the westward expansion of the railroads in the 1850 s, primarily in a two-story form which fit it comfortably on urban lots. A one-story version became popular in southern cities in the late nineteenth century, built from about 1880 to 1930 (McAlester and McAlester 1986:90). Similar forms have been noted in other parts of the world. As with other house types, there are probably numerous origins, none of which is necessarily related. These inexpensive homes have been built as workers' housing in various parts of the United States. The origin of the name refers to an old tale that a charge from a shotgun fired in the front door would come out the back door without hitting a wall (Gottfried and Jennings 1985:184).

\section{Pyramidal Roof}

One-story houses with nearly square plans, two rooms deep and two across, are generally covered with a pyramidal roof. In the south, these houses replaced the less spacious hall and parlor house in the early twentieth century. Urban houses of this type were often embellished with Victorian detailing.

\section{Styles Represented in the Alamodome Area}

The first eight houses were built in the area of the Alamodome in the period between 1850 and 1860 (Figure 1-3) by German families. None of these was still standing at the time of the APA study, but according to the Sanborn Insurance maps, they were all of the settlement saltbox type, indicated on the maps as "adobe." Archaeology in the downtown area has shown that nearly all the structures identified as adobe were actually built of a type of soft limestone called "caliche block." Foundations for these houses were generally made of harder limestone, whether the house was of either caliche or adobe. Archaeological investigations in the Alamodome area located and recorded these early house foundations (Volume II). There was no archival or archaeological evidence of the presence of flat-roofed adobe or jacal construction in the area. This might be expected because of the time period the area was settled and the German background of the first residents.

By 1880 there were 15 residences in the area (Figure 1-3), which primarily consisted of German families. The arrival of the Steves Lumber Yard and the Holmgreen Foundry (later to become the Alamo Iron Works) in addition to the extension of the Galveston, Harrisburg and San Antonio Railroad down Walnut Street, brought sudden interest in the area and sparked the construction of 38 new residences between 1880 and 1890. Many of the people moving into the neighborhood were workers for the iron works and the railroad, including a group of Polish artisans who came to work at the foundry (Adolph Beineck, oral history, April 20, 1990). Black workers at the iron works and the railroad lived just to the east and south of the Alamodome neighborhood (various oral histories, 1990). Between 1890 and 1900 , additional frame houses were built to fill the empty lots between earlier houses. It was not until after 1920 that Hispanic families began to purchase the houses along Hoefgen Street. An influx of Hispanics arrived in the early 1930 s as the result of the construction of Victoria Courts to the west, which had evicted them from that area (Roger Garcia, oral history, June 21, 1990). They 
purchased and moved into the small frame houses in family groups and before long had established their own neighborhood. Descendants of these families remember the area with affection, stressing that everyone looked out for each other.

After 1900 numerous rental houses were constructed along Cherry Street, some by the Steves family (Marshall Steves, oral history interview 1990), and a few by other neighborhood businessmen. In the $1920 \mathrm{~s}$, Block 636 at the southeast corner of the Alamodome area was subdivided into small lots, Runge Street was constructed to give access to those in the center of the block, and additional rental houses were built throughout this area. A number of these houses were eventually purchased by the tenants.

By the time of the APA photographic survey, construction of industrial buildings and parking lots had caused the demolition of many of the original houses.

The latter had been replaced, starting in the $1950 \mathrm{~s}$, by warehouses, industrial shops, and the expansion of the Alamo Iron Works in the northern part of Hoefgen. However, enough of the original houses remained to give a feeling of what the earlier neighborhood had been like.

The houses built in the area after the arrival of the railroad were styled houses of the various types described above. Examples of each of these types were recorded by APA and are illustrated here. According to our sources, the following statements can be made concerning the comparative dating of the various types of frame, Victorian houses.
1) The hall and parlor house (Figures 3-17 and 3-18) was the earliest type, probably dating from the 1880 s.

2) The plains cottage (Figures 3-19 and 3-20) was a late-nineteenth-century evolution of the hall and parlor house.

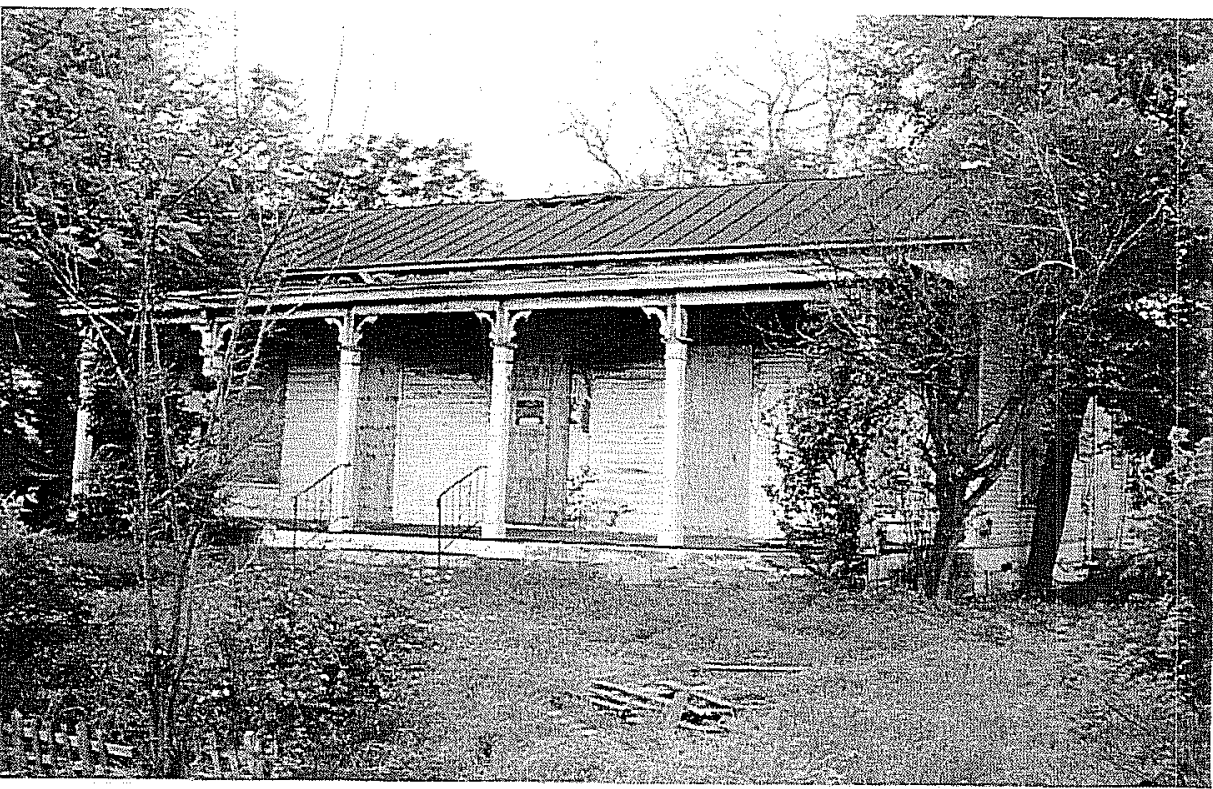

Figure 3-17. Hall and parlor house. Czernecki House, 724 Wyoming Street. APA 1990.

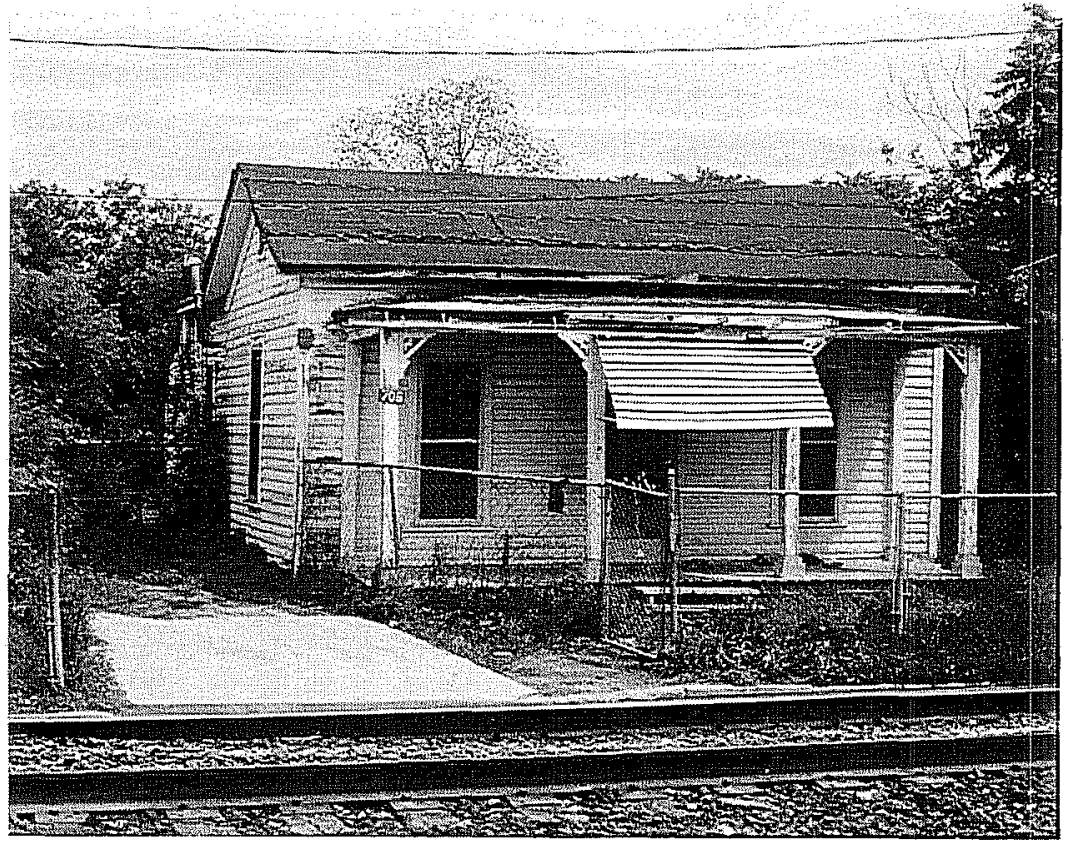

Figure 3-18. Hall and parlor house. 106 Martin Luther King Street. APA 1990 
3) The bungalow (Figures 3-21 and 3-22) was an innovation that became popular about 1895 to 1915.

4) The shotgun (Figure 3-23) was built for lower class housing from 1880 to 1930.

5) The pyramidal-roof house (Figure 3-24) was a twentieth-century version of the hall and parlor house.

The dates for these types are very general and meant merely as approximations.

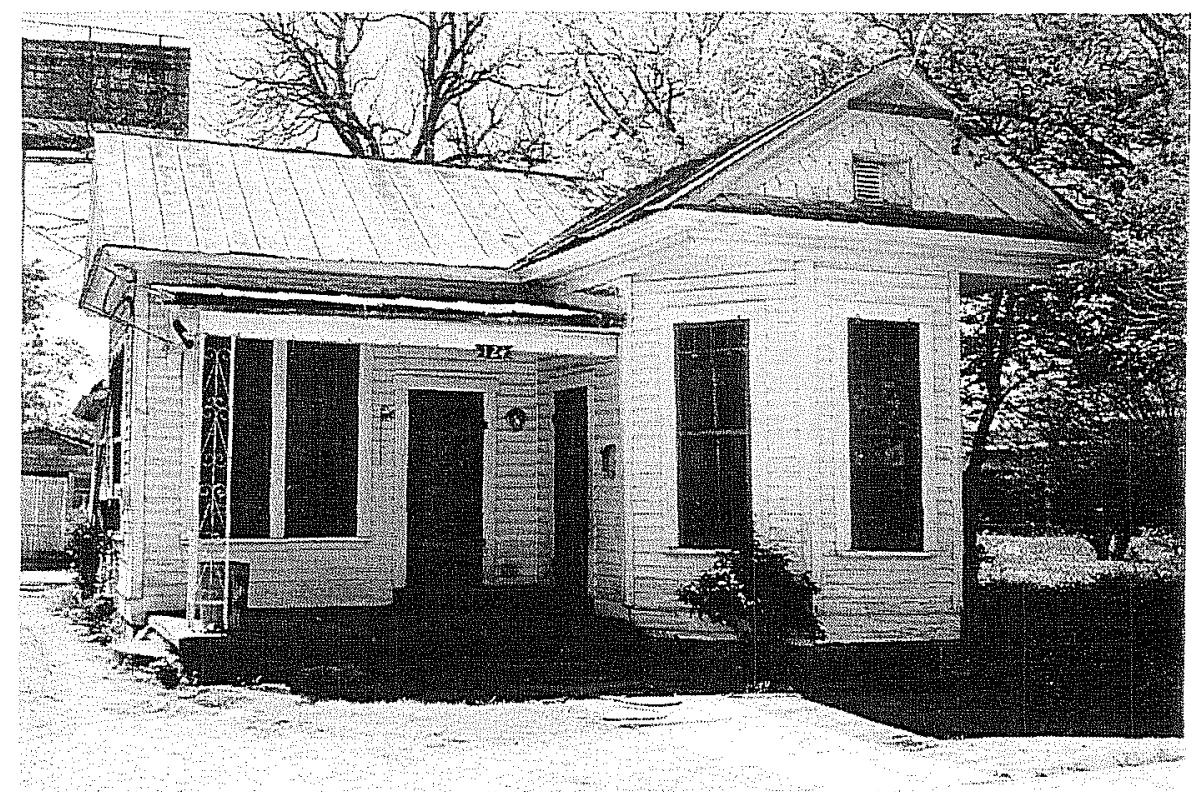

Figure 3-19. Plains cottage. 124 Nevada Street. APA 1990.

Analysis of the presence of these types in the Alamodome area has produced some interesting results. The intent has been to discover what the dating of the various types can tell us about the settlement, the ethnicity of the residents at various times, and the social history of the area. Classification of the houses illustrated by APA (Table 3-1) demonstrates how this area grew and shows groupings of houses on specific streets and areas that may have been built at approximately the same time. We see hall and parlor houses appearing on Nevada Street in the 1880s in the vicinity of settlement saltboxes already there, perhaps indicating common interests or backgrounds. Plains cottages were grouped on Nevada and Hoefgen during the housing spurt in the 1880 s to 1890 s, with a few hardy souls straying as far south as Nebraska (Martin Luther King). After 1900, the development of Cherry Street at the north end of the Alamodome area consisted of rental houses of pyramidalroof style, while those built in the Runge/ Cherry/Nebraska streets area in the 1920 s were all bungalows. Shotgun houses were built on alleys in fill-in areas and may also have been intended as rentals. Only three of these houses were recorded in the area.
We are fortunate to have the benefit of a photographic study of an area similar in size to the Alamodome area, done in Vista Verde South on the west side of San Antonio in 1979 (Brieg and Associate 1979). Both areas were developed in a similar time period-both were public lands sold by the city to private developers in the 1850 s-but had slightly different ethnic histories since the section on the west side has always been

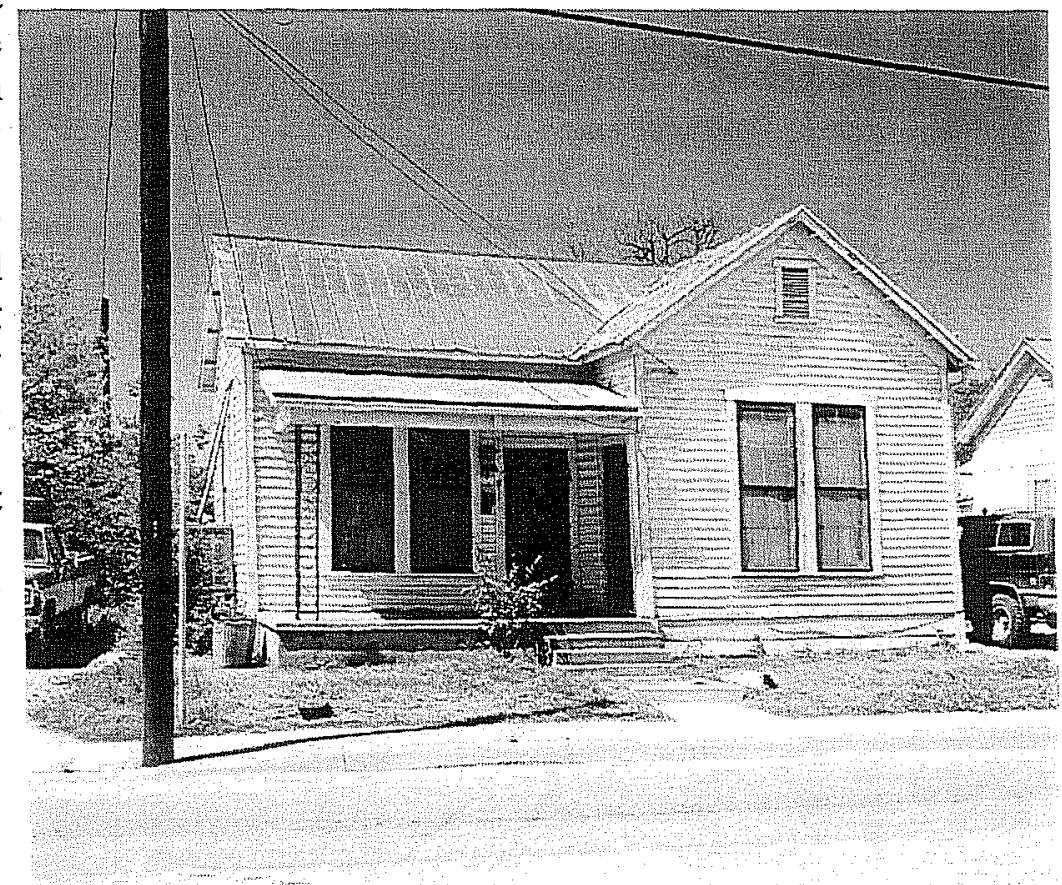

Figure 3-20. Plains cottage. 611 Hoefgen Street. APA 1990. 


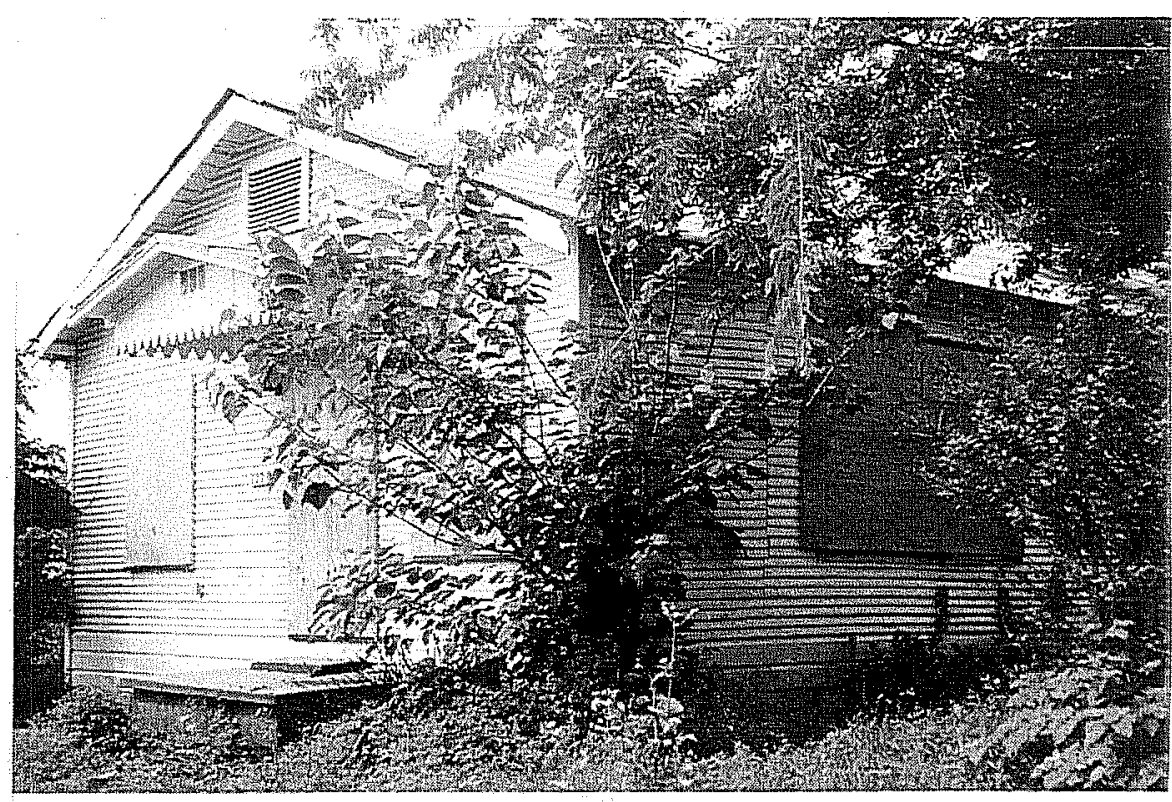

Figure 3-21. Bungalow. 727 Cherry Street. APA 1990.

to provide better-paying jobs than on the west side of the city. This is supported by the fact that during the late nineteenth century, the economic situation appears to have been equal in the two areas, judging by the types of housing people were able to afford at that time. More study of the changes that took place in the economic fortunes of the populations in the two areas is needed.

Tentative conclusions can be reached from careful analysis of the houses in a geographical area. By separating the houses into types with known periods of construction and approximate

predominantly Hispanic. A comparison of the types of houses present in the two areas before they were demolished (Figure 3-25) is quite revealing.

The development of the two areas started out very much the same, with settlement saltbox houses succeeded by hall and parlor houses through the $1880 \mathrm{~s}$, followed by plains cottages around the turn of the century. The major differences began to appear in the early $1900 \mathrm{~s}$, when the shotgun houses became the major house type being built in the Vista Verde area, in contrast to the Alamodome area where the predominant type being built was the bungalow. The ethnic background in the two areas during the twentieth century has been essentially the same, being predominantly Hispanic. The difference may reflect a contrast in the income levels in the two areas, since the Shotgun house has always been a less expensive house to construct, and requires a smaller lot. A possible factor could have been that Alamo Iron Works and other nearby industries and businesses were available

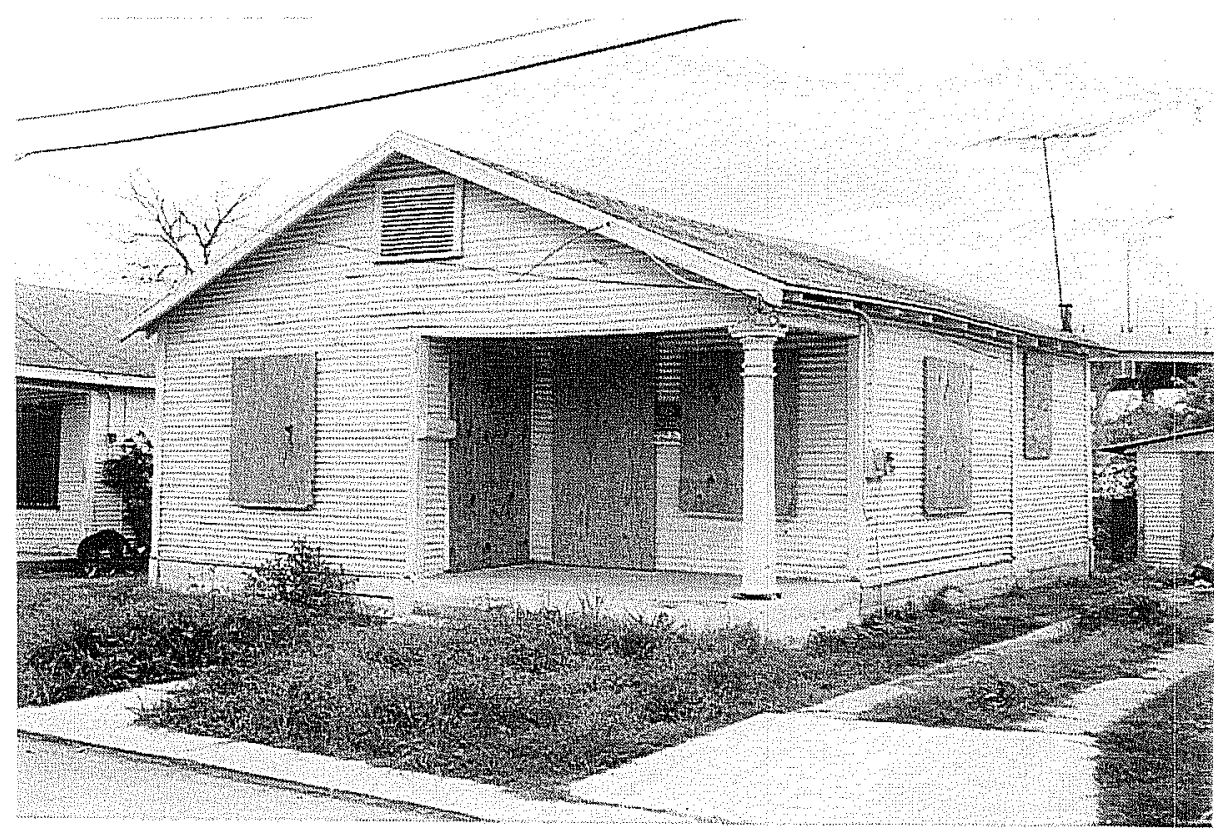

Figure 3-22. Bungalow. 725 Runge Street. APA 1990. 
cultural origins had already become blurred by the mixing of ideas from Spain, México, and Europe by the early years of the nineteenth century. Actually, if we add the influences of the United States, this accurately describes the culture of San Antonio today.

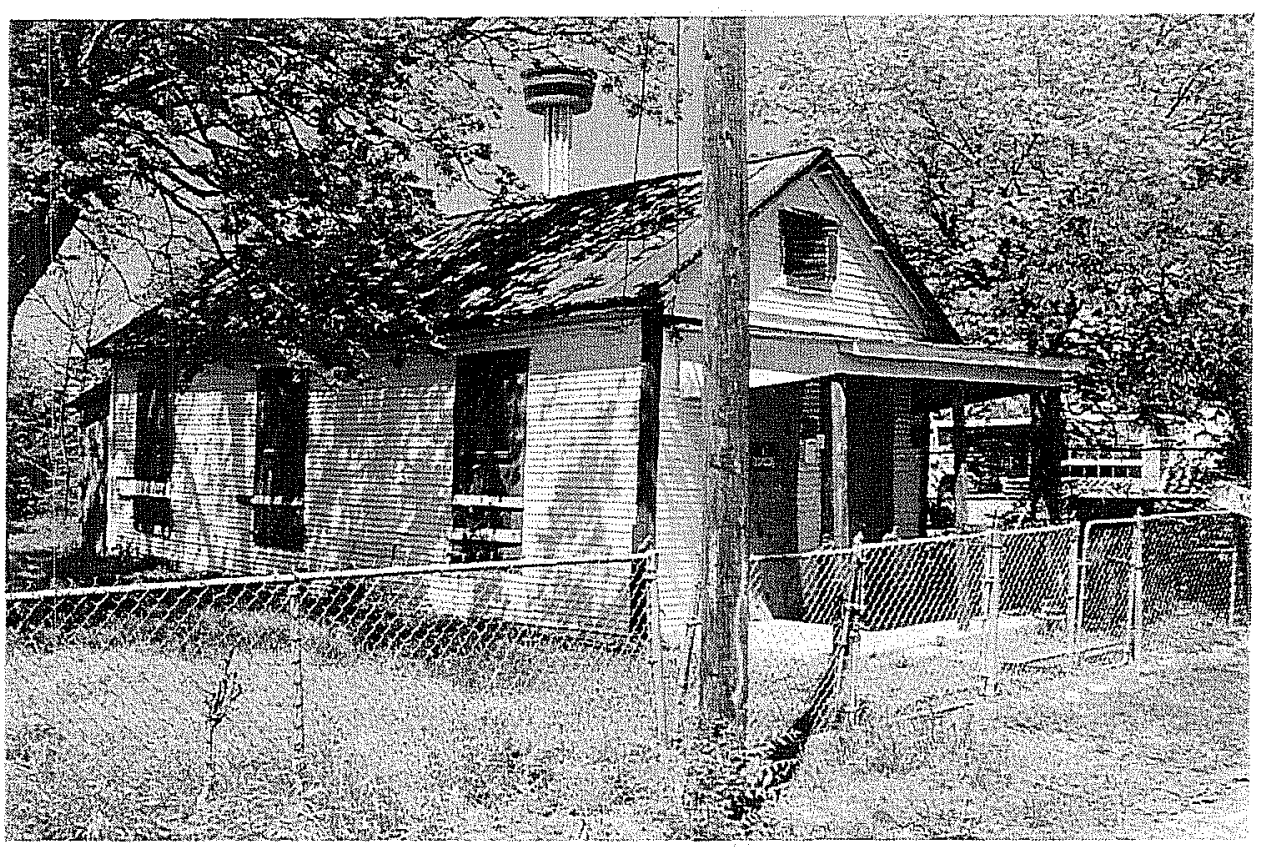

Figure 3-23. Shotgun house, 119 Grape Street. APA 1990.

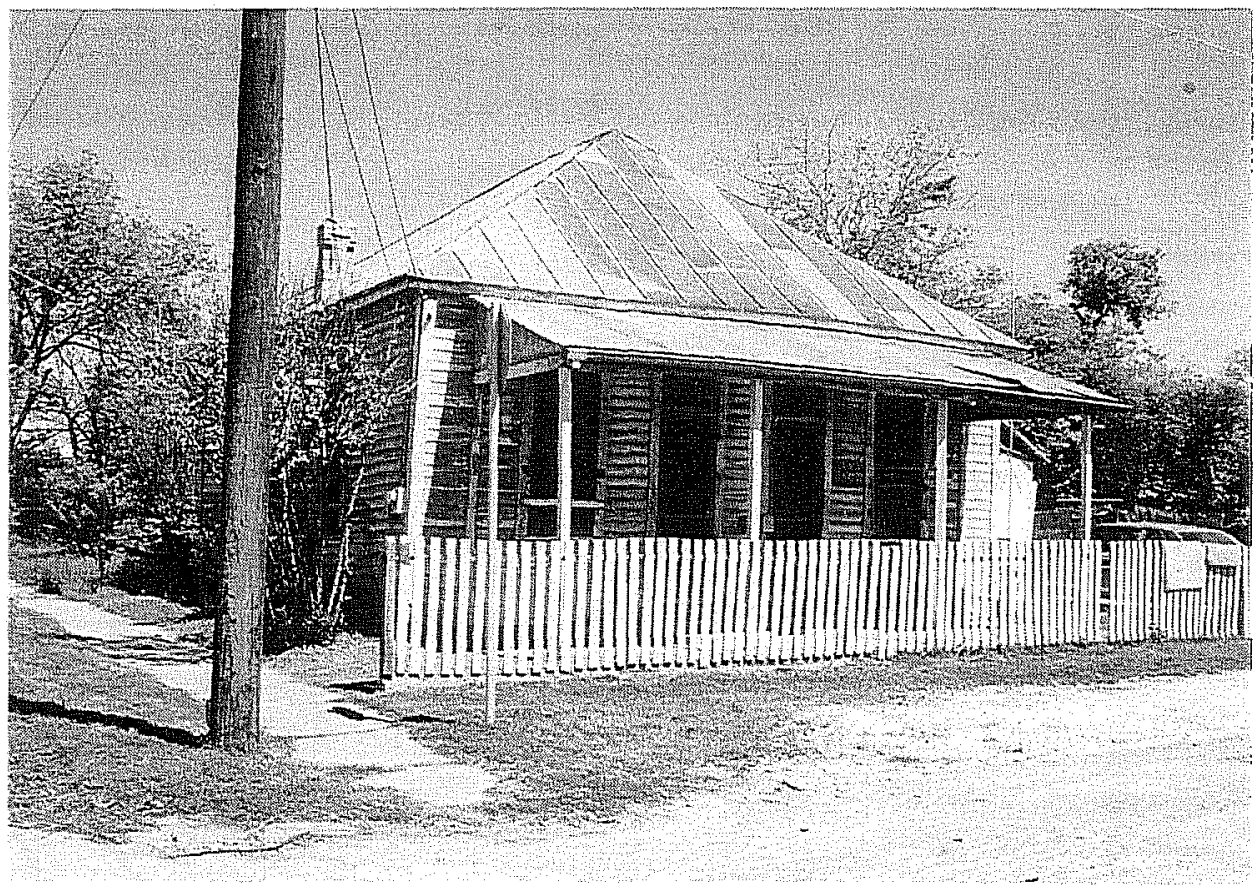

Figure 3-24. Pyramidal roof house, 203 Nevada Street. APA 1990. 
Table 3-1. Housing Types

\begin{tabular}{|c|c|c|c|c|c|}
\hline $\begin{array}{c}1850 s-1860 s \\
\text { Settlement } \\
\text { Salt Box }\end{array}$ & $\begin{array}{l}\text { 1880s } \\
\text { Hall \& } \\
\text { Parlor }\end{array}$ & $\begin{array}{l}\text { Late 1800s } \\
\text { Plains } \\
\text { Cottage }\end{array}$ & $\begin{array}{c}\text { 1895-1920s } \\
\text { Bungalow }\end{array}$ & $\begin{array}{c}1880-1930 \\
\text { Shotgun }\end{array}$ & $\begin{array}{c}1900 \text { s } \\
\text { Pyramidal } \\
\text { Roof }\end{array}$ \\
\hline 122 Wyoming & $106 \mathrm{MLK}^{*}$ & 110 MLK* $^{*}$ & 727 Cherry & 119 Grape & 603 Hoefgen \\
\hline 128 Wyoming & 214 Nevada & $114 \mathrm{MLK}^{*}$ & 719 Cherry & 139 Pablo Al. & 129 Nevada \\
\hline 132 Wyoming & 331 Nevada & $130 \mathrm{MLK}^{*}$ & 721 Cherry & 141 Pablo Al. & 131 Nevada \\
\hline 102 MLK* & 522 Nevada & 208 Nevada & 725 Cherry & & 401 Cherry \\
\hline 214 Dakota & 521 Nevada & 210 Nevada & 419 Cherry & & 403 Cherry \\
\hline 313 Nevada & 724 Wyoming & 124 Nevada & 117 Runge & & 411 Cherry \\
\hline 305 Nevada & 120 Pablo Al. & 217 Nevada & 131 Runge & & 415 Cherry \\
\hline \multirow[t]{10}{*}{325 Nevada } & & 123 Nevada & 129 Runge & & \\
\hline & & 610 Hoefgen & 127 Runge & & \\
\hline & & 616 Hoefgen & 125 Runge & & \\
\hline & & 618 Hoefgen & 123 Runge & & \\
\hline & & 607 Hoefgen & 119 Runge & & \\
\hline & & 611 Hoefgen & 124 MLK* $^{*}$ & & \\
\hline & & 619 Hoefgen & 126 MLK* $^{*}$ & & \\
\hline & & 126 Pablo Al. & 614 Hoefgen & & \\
\hline & & & 531 Hoefgen & & \\
\hline & & & 211 Nevada & & \\
\hline
\end{tabular}

* Martin Luther King (formerly Nebraska) 


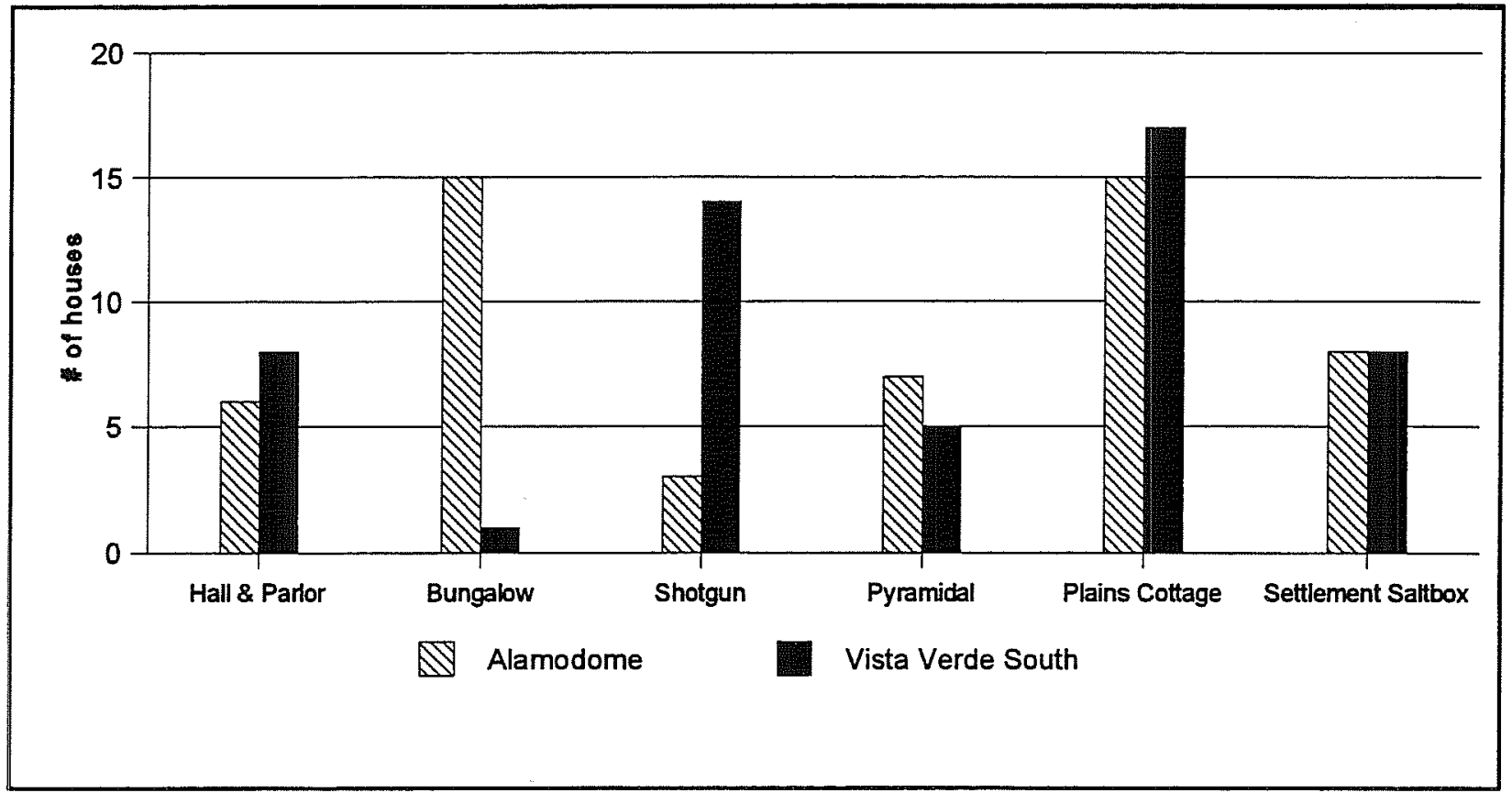

Figure 3-25. Comparison of house types. 


\section{Standing Structures in the Alamodome Impact Area Kevin J. Gross and Anne A. Fox}

All the structures in the footprint and laydown areas not salvaged for reuse were demolished in preparation for the construction of the Alamodome, with the exception of the Griesenbeck-Roatzsch House (41BX884). The latter, located at 123 Nevada Street, has been boarded up and preserved. The houses deemed worthy of reuse, plus those in the same condition in the parking areas, were turned over to the San Antonio Development Agency (SADA) for disposition. Wherever possible these were to be turned over to private owners who would arrange to move them off the site. Many, but not all, of the houses were moved to the Vista Verde South area. The Demazieres House (41BX945) was carefully dismantled and moved to another location in San Antonio.

Table 3-2 lists the properties that were demolished by contracts approved by the city, through SADA. The table summarizes the approved demolition parcels from the archives of SADA, which are being retained as legal documents to substantiate their involvement with the issue. The individual demolition contract and all supporting documents are boxed together and retained under locked storage in SADA's files.

Table 3-2. Disposition of Standing Structures

\begin{tabular}{|c|c|c|c|c|c|c|}
\hline Address & NCB & Type & 41BX- & Destroyed & Sold/Moved & Standing \\
\hline 1174 Commerce & 679 & railroad & & & & $\checkmark$ \\
\hline 331 Hoefgen & $14081 / 681$ & industrial & & $\checkmark$ & & \\
\hline 101 Montana & $14082 / 601$ & industrial & & $\checkmark$ & & \\
\hline 102-106 Montana & $14084 / 604$ & industrial & & $\checkmark$ & & \\
\hline 319-323 Hoefgen & $14083 / 605$ & industrial & & $\checkmark$ & & \\
\hline $201,213,225,233$ Wells & 607 & industrial & & $\checkmark$ & & \\
\hline 425 Hoefgen & 613 & industrial & & $\checkmark$ & & \\
\hline 420 Hoefgen & 614 & industrial & & $\checkmark$ & & \\
\hline 718 Wyoming & 615 & industrial & & $\checkmark$ & & \\
\hline 722 Wyoming & 615 & commercial & & $\checkmark$ & & \\
\hline 724 Wyoming & 615 & residential & 893 & $\checkmark$ & & \\
\hline 401 Cherry & 615 & residential & 894 & $\checkmark$ & & \\
\hline 403 Cherry & 615 & residential & 894 & $\checkmark$ & & \\
\hline 411 Cherry & 615 & residential & 894 & $\checkmark$ & & \\
\hline 415 Cherry & 615 & residential & 894 & $\checkmark$ & & \\
\hline 419 Cherry & 615 & residential & & & $\checkmark$ & \\
\hline 319 Dakota & 615 & industrial & & $\checkmark$ & & \\
\hline 313 Dakota & 615 & commercial & & $\checkmark$ & & \\
\hline 511 Hoefgen & 620 & commercial & & $\checkmark$ & & \\
\hline
\end{tabular}


Table 3-2. Disposition of Standing Structures

\begin{tabular}{|c|c|c|c|c|c|c|}
\hline Address & NCB & Type & 41BX- & Destroyed & Sold/Moved & Standing \\
\hline 120 Pablo Alley & 620 & residential & & & $\checkmark$ & \\
\hline 139 Pablo Alley & 620 & residential & & & $\checkmark$ & \\
\hline 141 Pablo Alley & 620 & residential & & & $\checkmark$ & \\
\hline 126 Pablo Alley & 620 & residential & & $\checkmark$ & & \\
\hline 521 Hoefgen & 620 & residential & & $\checkmark$ & & \\
\hline 531 Hoefgen & 620 & residential & & $\checkmark$ & & \\
\hline 129-131 Nevada & 620 & residential & & $\checkmark$ & & \\
\hline 127 Nevada & 620 & residential & & $\checkmark$ & & \\
\hline 123 Nevads & 620 & residential & 884 & & & $\checkmark$ \\
\hline 230 Dakota & 621 & commercial & & $\checkmark$ & & \\
\hline 219,233 Nevada & 621 & industrial & & $\checkmark$ & & \\
\hline 210 Dakota & 621 & commercial & & $\checkmark$ & & \\
\hline 119 Grape Street & 621 & residential & & $\checkmark$ & & \\
\hline 217 Nevada & 621 & residential & & $\checkmark$ & & \\
\hline 211 Nevada & 621 & residential & & $\checkmark$ & & \\
\hline 203 Nevada & 621 & residential & & $\checkmark$ & & \\
\hline 522 Hoefgen & 621 & residential & & $\checkmark$ & & \\
\hline 302 Dakota & 622 & commercial & & $\checkmark$ & & \\
\hline 330 Dakota & 622 & commercial & & $\checkmark$ & & \\
\hline $500 \mathrm{Bl}$. of Cherry & 622 & industrial & & $\checkmark$ & & \\
\hline 331/333 Nevada & 622 & residential & & $\checkmark$ & & \\
\hline 124 Nevada & 627 & residential & 956 & $\checkmark$ & & \\
\hline 603 Hoefgen & 627 & residential & 885 & $\checkmark$ & & \\
\hline 607 Hoefgen & 627 & residential & 956 & $\checkmark$ & & \\
\hline 611 Hoefgen & 627 & residential & 956 & $\checkmark$ & & \\
\hline 619 Hoefgen & 627 & residential & 956 & $\checkmark$ & & \\
\hline $\begin{array}{l}\text { City of S.A. Div. of Env. } \\
\text { Mgmt. }\end{array}$ & 628 & industrial & & $\checkmark$ & & \\
\hline 618 Hoefgen & 628 & residential & 957 & $\checkmark$ & & \\
\hline 616 Hoefgen & 628 & residential & & $\checkmark$ & & \\
\hline 614 Hoefgen & 628 & residential & & $\checkmark$ & & \\
\hline 610 Hoefgen & 628 & residential & 957 & $\checkmark$ & & \\
\hline 602 Hoefgen & 628 & comm.-res. & 895 & $\checkmark$ & & \\
\hline 208 Nevada & 628 & residential & 957 & $\checkmark$ & & \\
\hline 210 Nevada & 628 & residential & 957 & $\checkmark$ & & \\
\hline
\end{tabular}


Table 3-2. continued

\begin{tabular}{||l|c|c|c|c|c|c||}
\hline \multicolumn{1}{|c|}{ Address } & NCB & Type & 41BX- & Destroyed & Sold/Moved & Standing \\
\hline 214 Nevada & 628 & residential & 957 & $\checkmark$ & & \\
\hline SA Water Board & 629 & commercial & & $\checkmark$ & & \\
\hline 102 Martin Luther King & 636 & residential & 896 & & $\checkmark$ & \\
\hline 106 Martin Luther King & 636 & residential & & & $\checkmark$ & \\
\hline 110 Martin Luther King & 636 & residential & & $\checkmark$ & & \\
\hline 114 Martin Luther King & 636 & residential & & $\checkmark$ & & \\
\hline 122 Martin Luther King & 636 & residential & 938 & & $\checkmark$ & \\
\hline 124 Martin Luther King & 636 & residential & 937 & $\checkmark$ & & \\
\hline 126 Martin Luther King & 636 & residential & & $\checkmark$ & & \\
\hline 130 Martin Luther King & 636 & residential & & $\checkmark$ & & \\
\hline 131 Runge & 636 & residential & & $\checkmark$ & & \\
\hline 129 Runge & 636 & residential & & $\checkmark$ & & \\
\hline 127 Runge & 636 & residential & 932 & $\checkmark$ & & \\
\hline 125 Runge & 636 & residential & 931 & $\checkmark$ & & \\
\hline 123 Runge & 636 & residential & & $\checkmark$ & & \\
\hline 119 Runge & 636 & residential & & $\checkmark$ & & \\
\hline 117 Runge & 636 & residential & & $\checkmark$ & & \\
\hline 114 Runge & 636 & residential & 939 & $\checkmark$ & & \\
\hline 719 Cherry & 636 & residential & 936 & $\checkmark$ & & \\
\hline 721 Cherry & 636 & residential & 944 & $\checkmark$ & & \\
\hline 725 Cherry & 636 & residential & 944 & & $\checkmark$ & \\
\hline 727 Cherry & residential & 944 & $\checkmark$ & & \\
\hline
\end{tabular}




\section{References Cited}

Alexander, D.

1966 Texas Homes of the Nineteenth Century. University of Texas Press, Austin.

Andrew Perez Associates

1990 Architectural Inventory and Assessment, Multi-Use Dome Stadium site, VLA Transit Terminal Site. Interim Report prepared for the Center for Archaeological Research, The University of Texas at San Antonio.

Blumenson, J. J-G.

1977 Identifying American Architecture. A Pictorial Guide to Styles and Terms, 1600-1945. American Association for State and Local History, Nashville.

Burkholder, M. V.

1973 The King William Area. The King William Association, San Antonio.

1976 Down the Acequia Madre in the King William Historic District. Privately printed, San Antonio.

Carson, C. and W. McDonald, editors

1986 A Guide to San Antonio Architecture. American Institute of Architects, San Antonio Chapter.

City of San Antonio

1987 City of San Antonio Central City Resource Inventory 1983-1986. San Antonio.

E. R. Brieg and Associate

1979 Survey of Historic Structures/Vista Verde South. Prepared for the San Antonio Conservation Society. Manuscript on file. Center for Archaeological Research, The University of Texas at San Antonio.

Everett, D. E.

1975 San Antonio, The Flavor of its Past, 1845-1898. Trinity University Press, San Antonio.

Gottfried, H., and J. Jennings

1985 American Vernacular Design, 1870-1940, An Illustrated Glossary. Van Nostrand Reinhold, New York.

Green, R. M.

1952 Samuel Maverick, Texan: 1803-1870. Privately printed, San Antonio.

James, V. L.

1938 Frontier and Pioneer Recollections of Early Days in San Antonio and West Texas. Artes Graficas, San Antonio.

Jordan, R. G.

ca. 1980 A Gabled Folk House of the México/Texas Borderland. Manuscript on file. Center for Archaeological Research, The University of Texas at San Antonio.

Kniffen, F. B.

1962 Louisiana House Types. In Readings in Cultural Geography, edited by P. L. Wagner and M. W. Mikesell. The University of Chicago Press, Chicago. 
McAlester, V., and L. McAlester

1986 A Field Guide to American Houses. Alfred A. Knopf, New York.

Olmsted, F. L.

1978[1857] A Journey Through Texas, or, a Saddle-Trip on the Southwestern Frontier. Reprint of the 1857 edition published by Dix, Edwards, New York. University of Texas Press, Austin.

Spofford, H. P.

1976 San Antonio de Bexar. In Texas 100 Years Ago, Assembled from Harper's 1879 and Harper's 1877, compiled by $\mathrm{S}$. Wilson. Sun, Albuquerque.

Sturmberg, R.

1920 History of San Antonio and of the Early Days in Texas. St. Joseph's Society, San Antonio.

West, R. C.

1974 The Flat-Roofed Folk Dwelling in Rural Mexico. Geoscience and Man, V:111-132. 


\title{
Chapter 4 \\ Oral History Research
}

\author{
Maria W. Pfeiffer
}

\section{Introduction}

E. L. Fly and Associates, working in conjunction with the Center for Archaeological Research (CAR), conducted an initial investigation of the history of the San Antonio Alamodome Project site. Information was drawn from Bexar County deed records, published sources such as business histories and San Antonio city directories, and other public records, including city council minutes. Long-time associations with the area were identified through occupations listed in directories, length of residence at a particular address, and length of business occupation at certain locations. A list of possible interviewees was compiled from this work.

The interviews were conducted by various people, including E. L. Fly, several of his staff, and the author. Tape recordings of the interviews were transcribed by members of Fly's staff. Copies of the tapes and transcripts are curated at the CAR laboratory.

Subjects to be interviewed were chosen to represent the various business interests and ethnic groups in the area. Subjects included former employees of the Alamo Iron Works, area residents, railroad employees, and local businessmen.

\section{The Development of San Antonio's Near East Side}

\section{Late Eighteenth to Early Nineteenth Centuries}

Carlos Castañeda (1942), in his translation of the account of Conde de Sierra Gorda written to the viceroy in 1792 , describes "a fairly large settlement of families generally called agregados (squatters). It was with these that many of the mission Indians had intermarried." Castañeda (1942) interprets this to be a reference to the origin and development of $\mathrm{La}$ Villita. The introduction of the Compania Volante de San Carlos de Parras from San José y Santiago del Alamo in Mexico to occupy the abandoned mission of San Antonio de Valero in 1801 provided additional residents for the $\mathrm{La}$ Villita area.

The disastrous flood of 1819 demonstrated that the $\mathrm{La}$ Villita area (Figure 4-1), until then not considered a desirable place to live, was nonetheless on higher ground, and citizens began to petition for land in the area. The Cós House, ca. 1800, is the only preRevolution structure in the area. The fragile palisado and adobe houses of that period yielded to the more permanent construction of the post-1846 era. The Gissi House, a remnant of the palisado construction, was relocated from 141 South Street to La Villita in 1967. Dating to 1852 , it is characteristic of the early construction of La Villita that has been lost through demolition and deterioration. The remaining original houses of the La Villita area date to ca. 1850 through the late-nineteenth century. The early Hispanic settlement grew to become a mixed ethnic neighborhood by the early twentieth century, with German and black residents living in close proximity.

It is apparent from documentation by early San Antonio artists that the city had developed only a short distance out Commerce Street, or "The Alameda" as it was called. Herman Lungkwitz's well-known painting The Alameda (1856) shows the acequia crossing Commerce Street just east of Alamo Street with a scattering of stone buildings and the powderhouse, a 


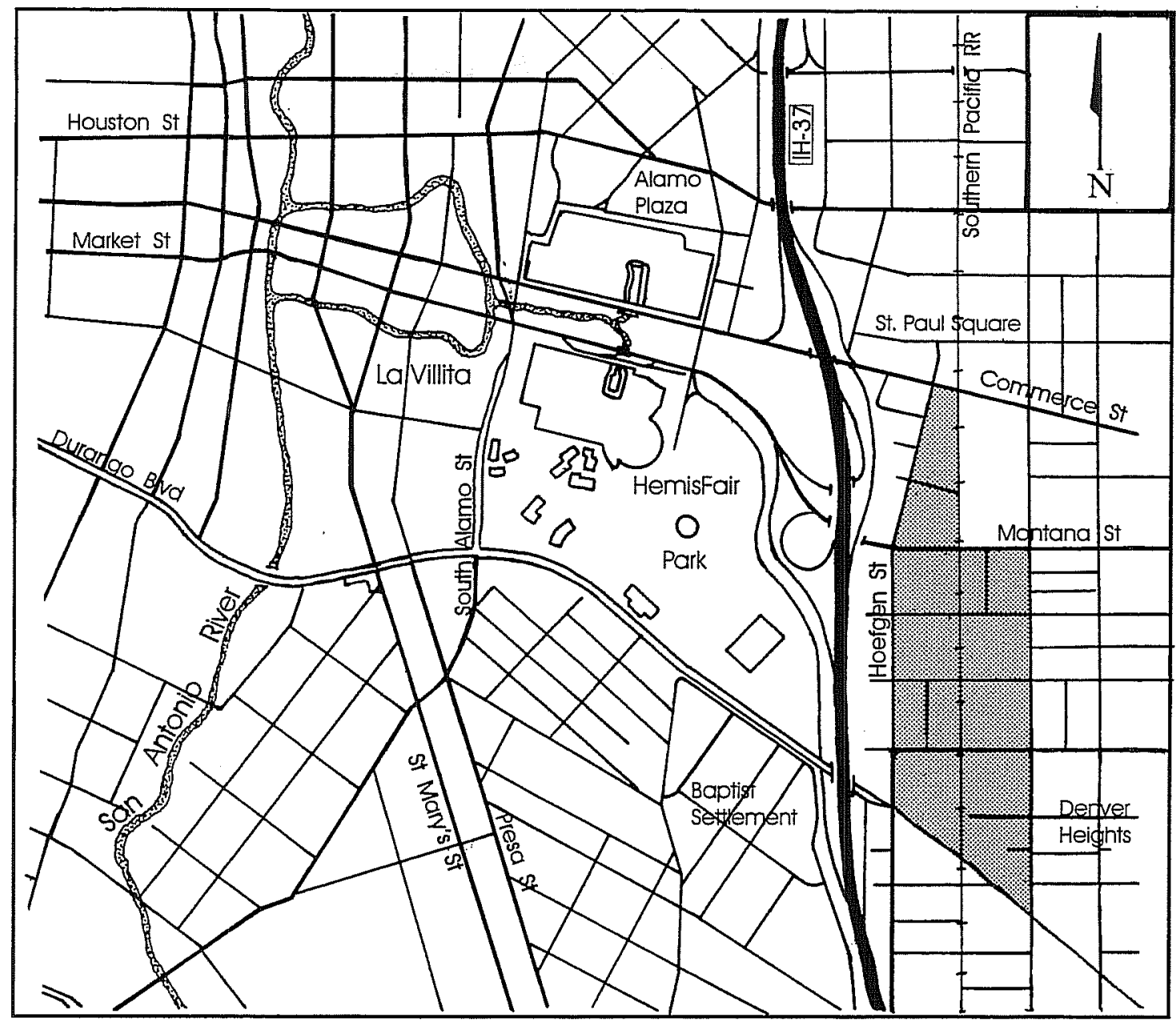

Figure 4-1. Alamodome Project area (shaded area) in relation to downtown San Antonio.

prominent local landmark, far in the distance (Pinckney 1967:92). Built by the Spanish as part of the defenses of the city, probably in the early nineteenth century, the powderhouse was a landmark rising on the most prominent hill east of the city.

Seth Eastman, who visited San Antonio on November 22,1848 , portrayed the "old Mexican lookout or watch tower at San Antonio," as well as the view toward the city from the hill showing a brushy expanse between the rise and the town. Theodore Gentilz, in his studies for the painting Corrida de la Sandia dated 1848 (Kendall 1974:84), also shows a barren expanse between the town and the powderhouse in the distance. The site of the Alamodome was a part of that vacant expanse.
The only mid-nineteenth century development east of the town occurred in 1853 when the first sales of city lands were made from a survey of 20 acres on the hill northwest of the powderhouse for use as burial sites. This culminated the process begun in 1850 by the city fathers to establish a cemetery outside the center of town. North of the cemetery location, Dr. Anthony $M$. Dignowity had purchased large tracts of land, making his home on the next hill north of Powderhouse Hill-Mount Harmony or Dignowity Hill as it became known. Dignowity also purchased land south of the powderhouse in 1856, part of which he sold to the Hazard Powder Company of Enfield, Connecticut. The property was used for the manufacture and storage of gunpowder until it was sold by the company in 1896. 
Lands to the east of downtown in the vicinity of the cemeteries were also used by local shooting clubs such as the San Antonio Schuetzen Verein, which had its hall on the south side of Wyoming Street "near Masonic Cemetery" in 1891 (City Directory 1891). Weekly meetings were held in the isolated area where ranges and clubhouses were located. The Alameda Club House, earlier known as the Miller Powder House property (today the northwest corner of East Commerce and Pine streets), was the only known commercial enterprise far east of downtown. Alameda Hall was a combination theater, music hall, dance hall, bowling alley, and shooting range (photograph, DRT Library). Residential development of the area dates primarily to the 1880 s and later, with much of the street system extended to the area ca. 1890.

\section{Late Nineteenth Century}

By the late nineteenth century, substantial growthboth commercial and residential-had taken place in San Antonio. The South Alamo Street area had taken on a character of its own. "Indeed this particular region has long been baptized 'The Little Rhein'. More explicitly and less intensely romantic, ... . [it] constitutes what is known in everyday parlance as the South Alamo Street saloons" (San Antonio Express [SAE], 17 August 1897). With the Commerce Street and Alamo Plaza business district flourishing to the north, Alamo Street became a bastion of German culture, both formal and informal. Otto Bombach's saloon, begun in 1855 at the southwest corner of Villita and South Alamo, continued to operate under various owners until 1949 when the famous "O'Con's Corner" was acquired by the San Antonio Conservation Society. Across the street, the Green Tree, run for many years by Fritz Achtzehn, served German fare until it was demolished for the construction of HemisFair. This spot was known to all San Antonians and still spoken of by those interviewed at the New Corner Cafe for this study.

The German English School, just a block to the south, opened in 1860, and operated until 1890. Beethoven Hall, built in 1895 and reconstructed after a fire in 1913, was the site of German entertainment by the Mannerchor until its sale in 1921, when the organization moved to new quarters on Pereida Street. The distinctive colonnaded facade of Beethoven Hall was lost to street widening in 1927. Muench Hall, an early entertainment center for Germans and home of the Alamo Rifles, San Antonio's first military company, stood at the southeast corner of South Alamo and South streets (SAE, 31 December 1939).

Goliad Street, which ran east from South Alamo to the city limits, became one of the most important residential streets in the town as the population settled at increasing distances from its center. The area east of South Alamo Street, today the site of HemisFair Park, was bisected by Goliad Street running to the east and the Acequia Madre running north/south. Both elements served to spur development in the area. Caliche and limestone cottages dating to the mid-1850s were mixed with two-story limestone mansions of the latenineteenth century belonging to leading citizens such as Meyer Halff (139 Goliad, 1893) and Solomon Halff (142 Goliad, 1877). Smaller homes dating to the 1850s and 1860 s on landmark streets like Lafitte and Water incorporated earlier architectural styles. The typical ethnic mix in most San Antonio neighborhoods of this time, German, Jewish, Polish, African-American, and Mexican citizens all lived immediately west of the study area.

The churches reflected the ethnic makeup of the neighborhood: St. John's Lutheran Church (corner stone laid 1860) on Nueva Street; the German Methodist Episcopal Church (1878) on Villita Street, later used by a black congregation; St. Michael's Catholic Church (established 1866) at 424 South Street, corner of Wyoming, which served the Polish population; St. Joseph's Catholic Church (site chosen 1859 , ground broken 1868 , dedicated 1871) on Commerce Street and attended by the Germans; Congregation Rodfei Shalom B'Nai Israel, the Orthodox temple located at 216 Wyoming; New Light Free Mission Baptist Church at 333 Lavaca and Mount Zion Baptist at 210 Santos, both south of Victoria Street serving the black population; together with St. Paul's Methodist Episcopal Church (1870) on Center Street. The Second Baptist Church, another black institution, was located on Chestnut Street but has been demolished.

The area south of Victoria Street (today's Durango Street) duplicated the HemisFair area in many ways, though there were fewer large homes. Koch's 1873 Bird's Eye View of the City of San Antonio (Figure 
3-14) shows development of the area well underway. Numerous small homes stand as far south as Barrera Street in 1873, with Koch's 1886 map reflecting much denser development (Figure 3-15). Subdivisions of land on Barrera Street in 1877 and Camargo Street in 1888 indicate the continuing growth of the city. Water Street, which exists only as a short fragment today, was a major north/south thoroughfare extending south from Commerce Street to its intersection with South Alamo at Refugio Street.

The 1879 city directory reveals the mixed settlement of the Lavaca Street and southern HemisFair area that had been seen earlier in the La Villita area and later in the Alamodome area. Certain blocks were occupied by blacks, immediately adjacent to those occupied by whites. The east end of Lavaca Street was exclusively black. That area, today the site of Victoria Courts, was known as the Baptist Settlement. It was, according to an interview with George Waitz, about a ten-squareblock area-a poor neighborhood "bordered by Labor Street back to where Victoria Courts ends" and including Peach and Refugio streets (George Waitz Oral History Interview, Institute of Texan Cultures). Sylvester Jones (Oral History Interview, CAR) remembers that within this area the population was "mostly blacks . . . about 20 percent would be Spanish [Hispanic]". Churches such as Mount Zion Baptist and New Light Free Mission Baptist were the center of that community, which is still referred to as the Baptist Settlemen (A. C. Sutton, Oral History Interview, CAR). The Baptist Settlement stood until 1940 when the area was condemned by the city of San Antonio for the construction of Victoria Courts. The area was cleared at that time of some 300 houses (San Antonio Light, 16 October 1940).

East of the railroad opposite the Baptist Settlement was Denver Heights, remembered by Mr. Jones as extending "just to New Braunfels at that time, and I'd say from Montana [on the] north and [to] Porter Street [on the] south." Here the population included primarily blacks, but also a few Chinese families who ran grocery stores. There were also a few AngloAmerican and German people who had bakeries and grocery stores. They had "nice houses . . . very scattered. You'll see maybe two or three in this block, maybe two in the next block and you might go over another four or five streets before you get to another couple of families" (Sylvester Jones, Oral History Interview, CAR).

\section{Early Twentieth Century}

George Waitz was born above his family's store at 548 Goliad Street in 1917. The business, begun in 1886 by Frank Weber, was purchased by the Waitz family in 1913 and operated as "Weber's Grocery" until the Depression, when the name was finally changed to reflect Waitz's ownership. Relocated at the time of HemisFair, the store moved to Sunset Ridge on North New Braunfels, then to Austin Highway where it continues to operate. The store on Goliad Street was a neighborhood landmark, as was Henry Hein's Goliad Street Pharmacy (600 Goliad) and Ludwig's Meats (200 Iowa). These businesses were all remembered in the interview with Paul Guidry and the New Corner Cafe patrons. As the city grew to the east, the electric streetcar line was extended out Victoria Street, making a loop through Denver Heights and back to town. Denver Heights, platted in 1890 , later became the home of the city's prominent black citizens, and George Waitz remembers his customers who continued to frequent the store from the early days, making use of the streetcar for transportation.

The electric streetcar line extended to the east out Commerce Street. Known as the Cemetery Line, the railway ran to the East End subdivision just to the north of the Denver Heights Line. The extension of the streetcar lines also made it possible for the employees of area businesses such as the Steves Lumber Yard and Alamo Iron Works to live farther away from their place of work. This caused gradual changes in the demographics of the neighborhood. Also contributing to change was the demolition of the Baptist Settlement, which pushed families farther east. Roger Garcia (Oral History Interview, CAR) remembers when his family moved to Hoefgen Street and bought several houses close together there. Sylvester Jones (Oral History Interview, CAR) remarks that a number of Hispanic families started moving into the general area after the 1940s. Another impetus for change apparently came as a result of the construction of HemisFair in 1967 (Adolph Bienek, Oral History Interview, CAR) which again uprooted families and caused some to move east into the project area. 
Commerce Street east of Alamo Plaza had developed as a combined commercial and residential area, and substantial homes such as the Friedrich Groos house (314 East Commerce Street, constructed 1873, demolished 1967) had been built. The area north of Commerce Street and east of St. Paul's Church was another black residential area (A.C. Sutton, Oral History Interview, CAR). The extension of the railroad tracks along Walnut Street in 1877 provided an impetus to both residential and commercial development.

\section{Alamo Iron Works}

The neighborhood bounded by Commerce, Victoria, Peach, and Cherry streets, with streetcar tracks on its north and south boundaries and the railroad through its center, had finally become a desirable development location. Development of the area began as early as 1884 when George Holmgreen, who had arrived in San Antonio in 1878, became the principal partner in the Schuhle and Nixon foundry, purchasing the business and bringing his sons Eugene and Julius back to the city from the North as his partners. The iron works, first located on the southeast corner of Presa and Market streets, was forced to move to a more isolated location by concerned neighbors and city fathers. A one-acre site was chosen approximately one-half mile east of the Alamo "out in the mesquite brush." There Holmgreen located his fledgling foundry, and machine and pattern shop, all run from a small office. The operation opened at its new site in April 1885. When Alamodome construction began, the site had grown to 17 acres, and Alamo Iron Works, the name Holmgreen gave to his business in 1899 , had presided over the development and the decline of San Antonio's near East Side.

Everyone carried his lunch, or went home for lunch, for many years. Then in 1949, Paul Guidry opened the Corner Cafe at Hoefgen and Wyoming streets. It was an overnight success with such dishes as shrimp creole and rice, roast beef, liver and onions, kidney stew, spaghetti, and noodles and sausage. A plate lunch cost $\$ 1.55$ (Paul Guidry and Grace Dorrington, Oral History Interview, CAR). Never short of customers, the little cafe burst at the seams when the laborers who built the HemisFair discovered it. When the Alamo Iron Works finally took over the property for expansion in 1984, the cafe-and its patrons-moved about two blocks to a building on Wyoming Street. It was not until the Alamodome project began that the cafe closed and Guidry retired.

The area chosen by Holmgreen for his growing business was, of necessity, isolated. Also important was the proximity of the newly established railroad. The Galveston, Harrisburg and San Antonio Railroad had entered San Antonio in 1877, and its main yards were a short distance north of the iron works at Tenth and Austin streets. The construction of the Southern Pacific passenger depot in 1902 to serve the heavily traveled Sunset Line brought additional commercial impetus to the area. The depot brought the need for hotels and related services. Facilities such as the Mission Hotel (1906), the Lone Star Hotel (1910), and the Fairmount Hotel (1907) were all constructed to accommodate travelers. Those with first-hand recollections of the depot during its heyday remember the large number of troops during wartime and their scramble between trains to procure liquor at the nearby package stores (Agnes Mahula, Oral History Interview, CAR). Others remember that on Sunday mornings, before purchasing liquor was allowed, blacks would gather around the Heiman Hotel and sell bottles illegally (New Corner Cafe, Oral History Interview, CAR). Hack drivers and later jitney operators would gather around the depot to convey travelers to their final destinations. Frenchie's Blackout Cafe was a popular destination of locals and visitors alike. Marshall Steves remembers that his grandfather was a frequent patron of the cafe which was across Commerce Street from the lumber yard. Steves recalls that his grandfather would drink beer, get into his carriage, go to sleep, and his horse would take him home to King William Street (Marshall Steves, Oral History Interview, CAR).

Perhaps due to the large working-class population in the area and its adjacency to the railroad, a number of rent houses were built in the neighborhood. Marshall Steves (Oral History Interview, CAR) remembers a row of some nine one-story frame houses on the west side of Cherry Street between Commerce and Idaho that were built by his father for rental property. 


\section{Steves Lumber Yard}

Ed Steves began his lumber yard in 1866, locating at Blum and Bonham streets, and later on the west side of Alamo Plaza. When the railroad arrived in 1877, Steves moved his yard to Lamar Street, and established another yard on East Commerce Street in 1883. The Lamar Street yard was moved to the west side near the International and Great Northern tracks in 1881 (Steinfeldt 1978). The company, which became known as Ed Steves and Sons in 1879, continued to operate at the Commerce Street location until 1980.

The facility was expanded in 1912 to include a small factory for the manufacture of millwork-a plant dubbed the "Coffee Mill" by its critics. It proved to be so successful that Steves Sash and Door Company became a separate operation in 1913, moving to a site at Monterrey and Medina streets on the west side (Steves and Sons brochure, 1986, property of Marshall Steves). The original planing mill was to the south of the lumber yard, near Idaho Street and, following the move in 1913, was sold to the Schultze Brothers Manufacturing Company which had a similar operation there until 1961. This represented an expansion for Schultze Brothers, which had operated at 110 Idaho Street since 1897 . Founded in 1895, the company produced "artistic cabinet work" including fixtures for churches, offices, and factories. Ed Steves and Sons Lumber Yard continued to operate on Commerce Street until 1985, when it closed for financial reasons. In 1985 Marshall Steves, who had run Steves Sash and Door Company since 1955, changed his company's name to Steves and Sons. That plant has operated at 203 Humble since 1955.

The lumber yard did not employ a large number-only 20 to 25-including blacks and Germans and, as Steves recalls, many blacks who spoke German (Marshall Steves, Oral History Interview, CAR). This was also remembered in the black population according to Sterling Nious, Sr. (Oral History Interview, CAR). Steves remembers a neighborhood not a great deal different from today's area, although parts of it-such as St. Paul Square-have been cleaned up. Since his youth working at the lumber yard, the area had been mixed in use and ethnicity, and generally deteriorating.

\section{Oral History Interviews}

The 13 interviews conducted provide a description of a neighborhood in transition throughout the memory of all interviewees. Anglos, Hispanics, and blacks lived and worked in an area that mixed commercial and residential development. Jewish, German, and Polish citizens combined in a rich ethnic mix that no longer exists in any San Antonio neighborhood. The information gathered about Baptist Settlement, the HemisFair area, and the Commerce Street commercial strip gives insight into an important part of the city's development that has been demolished. The in-depth research and documentation for the Alamodome project area has therefore provided not only a valuable picture of that immediate area, but an opportunity to place the Alamodome site in a broader context of urban growth. Together with recent research on the East Side cemetery complex and surrounding neighborhoods, this body of information gives historians and planners the most comprehensive view of San Antonio's eastward growth to date.

\section{Oral History Summaries}

The following summaries of oral history interviews demonstrate the variety and detail encompassed by these valuable documents. Information gleaned from these will allow the reconstruction not only of the immediate neighborhood around the project area, but of the surrounding areas that have regrettably been demolished in preparation for HemisFair in 1968 and the construction of $\mathrm{IH}-37$ soon afterward. At the time that these projects were carried out, no historic preservation laws were in force such as the ones we currently have to guarantee the collecting and publishing of oral, architectural, and archaeological information.

In these summaries the information has been limited to references to the project area and its immediate environs. Each one also contains a great deal of other detail on neighboring areas, people, and events. Copies of all of the interviews were offered to the Oral History department of the Institute of Texan Cultures and to the library of the San Antonio Conservation Society. 


\section{Interview with Adolph Bienek}

Mr. Adolph Bienek worked for Alamo Iron Works all his adult life. Mr. Bienek's family moved to San Antonio from between Seguin and San Marcos in 1925 , when he was 15 years old. He started working for Alamo Iron Works and stayed until he retired. His first job was as a tool boy, seeing that all the tools were sharp, caring for the bolts and wrenches. The foreman was Mr. Timan and Bienek worked for him in the shop for 21 years. When Mr. Timan retired, Mr. Bienek's brother became shop foreman. Mr. Bienek's father and three brothers also worked for Alamo Iron Works.

When they came to town, the family rented a home at 915 Wyoming Street (two blocks east of the Alamodome Project area). Mr. Timan lived next door. They bought a home in the next block in 1928, and the children grew up there. Adolph married and moved to 844 Dakota Street, near Alamo Iron Works, for two years, then moved to Highland Park, then to the Hot Wells area.

When Alamo Iron Works went into defense work, Adolph was deferred from service. Quite a few of the people at Alamo Iron Works lived in the neighborhood, but others did not. When he first started there in 1926, about 500 people were employed, a few blacks, quite a few Hispanics, and a lot of Polish people. The foundry was mostly all Polish. Bienek recalled,

Mostly everybody brought their lunch. We used to walk home for lunch when we lived on Wyoming Street. We went to work at 7:45, had an hour for lunch, and got off at 5:15. At that time, we were working a half hour a day extra so we could get off at noon on Saturdays. We worked 48 hours a week. When we lived on Wyoming Street, we could go a block to a grocery store, one more for a bakery, a meat market the other way. Every other corner on the block there was a grocery or a drug store. The Heinz Drug Store was on Victoria Street and Santa Clara Street. There was a bakery at Hoefgen Avenue and Victoria Street. There were also florists and two mattress companies. The San Antonio Machine Supply Company was on Houston Street. They did a lot of the same kind of work that Alamo Iron Works did.
In 1926 Alamo Iron Works began to tear down its old shops and build new ones. Railroad tracks were being installed where the railroad bought $50 \mathrm{ft}$ of the property from Alamo Iron Works. Trains were unloading people two or three times a day. The beginning of the Great Depression slowed the production and growth of Alamo Iron Works. However, it wasn't until the early 1950s that the company began experiencing an increase in production and a hint of growth.

The freight depot was built during the time that everything was shipped by rail. As time passed, trucks became the principal mode of transporting goods into San Antonio. Eventually, the depot's dock was torn down due to its infrequent use.

There were many changes in the neighborhood after HemisFair. Numerous small businesses had to move out. Then later on the large chain stores began cutting out the corner stores, and they ran out of business.

\section{Interview with A. C. Sutton}

Mr. Sutton's family has long been active in business and civic life in the city's black community. The area directly south and southwest of the Alamodome project area was known as the Baptist Settlement. There were two major Baptist churches in the neighborhood. The area was originally a German community, with a settlement of blacks "in back of it" (to the east).

Santa Clara and Victoria streets were the main routes to downtown from the black neighborhoods, which started directly east of the Alamodome project area. The poor people had cisterns that were filled from gutters on the roof of the house.

There were stores available to the black neighborhoods on Victoria and Labor streets, but there were no black-owned stores there. Black stores available were the Burgess Store at Lockhart and Nolan streets, and several others on the west side.

The blacks settled just beyond the railroad on the east side of the track, and down south of Durango Street to Virginia Boulevard. East of Cherry Street around Alamo Iron Works was an area of Polish and German 
people. There were also other kinds of small businesses that serviced the area.

Black people were hired to care for the horses used in the various businesses, as well as owning or running hack services and freight wagons in connection with the railroad. Some of them lived in little houses up and down the tracks in the Houston and Commerce streets area. Some of them worked for the railroad, repairing and servicing the tracks.

The railroad station was a gathering point for blacks living in the area. They enjoyed the excitement of the arrival of the trains. Blacks would congregate in a certain area to greet incoming black people, who always rode in the first car behind the cab of the train.

A produce warehouse was located near the Merchants Ice House on the corner of Houston and Walnut streets. Mr. Sutton's father had a funeral home on the first floor of the Odd Fellows Lodge hall. There was a section in back of the city cemeteries where blacks were buried.

The YMCA at Pine and Cross streets was the cultural and recreational center for the area. The Women's Progressive Club supported the Ella Austin Children's Home (an orphanage) and the "Y." The blacks owned the UBF Hall on Commerce Street which was taken for the IH-37 expressway. There were a number of other black-owned buildings in that area that were also eliminated by expressway construction. They were mostly pool halls and things like that.

\section{Interview with Sterling Nious, $\mathrm{Sr}$.}

Mr. Sterling Nious, Sr., was an employee of the Alamo Iron Works from 1941 to 1973 . Mr. Nious came to San Antonio from La Vernia as a young man. He started working at Alamo Iron Works right after Pearl Harbor in 1941. His brother worked there first, and got the job for him. He worked in the foundry, cutting, packing, and loading steel into box cars, among other jobs. He also helped unload sand, gravel, and coke.

Nious was deferred from service during the war because of his job. At first he lived on Walters Street, where he bought a house for $\$ 300$. (Walters Street is ca. five blocks east of the cemeteries.) He remembers a cafe on the corner, and Margozewitz's brass foundry nearby.

There were many trains coming and going, and they were always adding something to Alamo Iron Works. There were many Polish workers in the foundry, and Germans in the machine shop. He went to work between 7:30 and 8:00, riding the bus to work at first, then he bought a car. Not too many of the workers lived in the neighborhood, but rather "out on the east end." The people in the machine shop lived nearby. During and right after the war, quite a few people "from overseas" worked there. Most of his friends worked with him, in different departments. Some of his friends spoke German, learned because they worked with Germans either at Alamo Iron Works or at the Steves Lumber Company nearby.

\section{Interview with Marshall Steves}

Mr. Marshall Steves is from a prominent San Antonio family which has been in the lumber and millwork business for several generations. His grandfather started Ed Steves Lumber Company on Alamo Plaza in 1866 . He moved to Commerce Street about 10 years later (where Rosemary's Catering is now). His grandfather also built little houses on Cherry Street that backed up to the lumberyard as rent houses. South of the lumberyard was the planing mill, later became the Schultze Brothers planing mill. The lumber mill preceded the arrival of the railroad, and had considerable influence on the extension of the railroad through the area.

Steves feels that the area is less industrial today than when he worked there 50 years ago. They had a lot of German-speaking blacks working for the lumberyard. Will Edwards and Willie Duke were black men who spoke German, but they did not live in that area.

\section{Interview with Roger Garcia}

Mr. Roger Garcia lived in the area from the time he was five years old until 1968. His mother bought several houses: the first at 614 Hoefgen Avenue from Mrs. Treviño; the second house was across the street at 611 Hoefgen Avenue; and last, she bought the 
house next to 614 Hoefgen Avenue from the Garzas. At the corner was Mr. Garza's grocery, the mending shop, and next to her was Ramos, an insurance salesman. Next to Mr. Garcia's house was Moran. Then at the corner was Frank Perez.

A couple of people in the neighborhood worked at Alamo Iron Works. One of the people in the mending shop was an insurance salesman, and the other was a lawyer. Behind Garza's grocery store was Las Zapatas, on Nevada Street.

On Grape Street was the Gus Peter family; they had much land, a house on Hoefgen Avenue, and owned from Hoefgen Avenue to Grape Street. There were very few Anglos, mostly Mexican-Americans in this area. Everyone knew everyone and watched each other's house; even doors were left open. Everyone had a car, but a lot of them did not use it because the bus stop was there on Victoria Street. Mr. Garcia went to Herff Elementary School at Hackberry and Victoria streets, then to Sadege and Cole middle schools, and from there to Fox Tech High School.

People mostly cooked and ate at home. When they wanted to go out to eat, they went to restaurants on the West Side. Garza's grocery store was still operating until recently. He went there to buy his beer.

\section{Interview with Sylvester Jones}

Mr. Sylvester Jones was born in 1918 and has lived on the East Side all of his life. He was born and raised in the Baptist Settlement, now called Victoria Courts. The Baptist Settlement was torn down in early 1941 to build Victoria Courts. The boundaries of the old Baptist Settlement were Carolina Street, Alamo Street, Goliad Street, and the Southern Pacific Railroad tracks. East of the tracks was Denver Heights, mostly blacks. Also most in the Baptist Settlement were blacks, with maybe 20 percent Hispanics. Denver Heights went from Montana Street to Porter Street on the south and as far as New Braunfels Street on the east. There were a few Orientals; some Chinese had grocery stores. Most of the big businesses were white. Bakeries and mercantile stores were white and German. The whites were scattered around, just a few families.
The majority of the blacks in the Baptist Settlement were middle-class survivors of the Depression. Denver Heights was about the same. Most of the men who worked were Pullman porters for the railroad, or worked in construction. A few sold wood or ice. Others worked for Alamo Iron Works in nonskilled positions.

Steves Lumber Company went from Commerce Street to Montana Street, across the tracks from the station. On Victoria Street at Hoefgen Avenue there was a pool hall, where Bill Miller's is now. There was a Lone Star Ice House there.

\section{Interview with Sylvester Jones and Mr. Runnels}

Most of this conversation concerned the area directly north of the study area, between Commerce and Houston streets. This was a totally black area until Mexican-Americans started coming in after the 1940 s. Most of the people on the east side were working at the Southern Pacific roundhouse or the rip track, where the freight yards are.

The cab stand was on Commerce Street. There was a popular black cafe between Cherry street and Mesquite street. It stayed open all night. Under the freeway was the Sunset Pawn Shop, then the Angel Miner's Inn, and then the cab stand, going east.

There were three streets going into town: Commerce Street, Houston Street, and in the Denver Heights/ Baptist Settlement you had Goliad Street. They were all streetcar routes.

The Corner Cafe used to be at Hoefgen Avenue and Wyoming Street. There was a Greek cafe; they were there for ages, the only cafe around for a long time. The Heinz Drug Store was at Goliad and Santa Clara streets. At Iowa Street and Hoefgen Avenue was a mercantile store.

The freeway replaced mostly businesses in there. It got the bakery and a couple of big markets. Peach Street was eliminated. People in there were all Orientals and Germans. You did not get into the black area until you crossed Hoefgen Avenue. 
There was a little sewing shop at Hoefgen Avenue and Nevada Street, with a Spanish lady who used to do Runnels's grandmother's sewing. The little shop is still there. She used to make aprons and fix pockets and "all that kind of stuff."

On Runge Street were mostly all blacks. They eventually bought those small houses, the shotgun ones.

\section{Interview with F. A. Laskowski}

Mr. F. A. Laskowski works for Alamo Iron Works, and has been there since 1973. Mr. Laskowski's regular job is plant maintenance for the iron works. When interviewed, he was organizing the moving of equipment to the new site.

Some of the equipment there was " $60,70,80$ years old" and was recently sold at auction; much of it is going to Mexico. Also, they are going from an 18-acre site to a 10-acre site, and some things have to be discarded.

There is a story that the whistle came from New York, one of the Holmgreens heard it and liked it and brought it back. It was a steam whistle but has been converted to air. If it is 20 or $\mathbf{3 0}$ seconds off, people call to say it's not on time. It blows at 7:00 A.M., a little short one; at three minutes to 8:00 A.M., three little toots to warn people they have three minutes; then the first loud one at 8:00. At 12:00 there's a loud one; at 12:27 three little toots warning, then one at 12:30; then at 1:00 we have a loud one again. It is going to be moved to the new site at 943 Coliseum Road, where they are planning to have an antique room.

\section{Interview with Baxter Grier}

Mr. Baxter Grier retired from Alamo Iron Works as president, had worked there since 1937 . He started as a machinist's apprentice, got the job because of his friendship with Leo Bienek, brother of Adolph Bienek (see Interview with Adolph Bienek). The job consisted of sweeping the floor and taking tools away from the machinist. He began to take an interest in mechanical engineering and took an International Correspondence School course.
When he started working there, Alamo Iron Works had five branches or locations. A place in Houston fabricated steel. In Corpus Christi was a smaller version of the San Antonio plant. There were smaller places in Brownsville and San Angelo. The total payroll was around 500 or 600 people. During the time he was there, they kept acquiring more property, a piece at a time. This was during the Depression, which hit San Antonio in the early 1930s and lasted through 1939.

The Germans had the brains and the talent in engineering. The next layer of skilled workers were the Polish, then the blacks and Hispanics were the laborers.

Many of the workers lived nearby. E. A. Holmgreen, who was then in charge, lived on Goliad Street (in the HemisFair area) and went home for lunch every day. The whistle was used by everybody to get up and go to work.

In the 1930s the railroad was a way to get around, and the depot was quite a place to be. East Commerce Street was a pretty nice business area. There were some hotels and the Southern Pacific Depot and a jewelry store. The neighborhood was "a part of Alamo Iron Works," and it was an honorable place to work.

Once a week they stood in line to get paid in cash. They worked eight to five, and until five on Saturdays. There were no paid holidays or paid vacation or paid sick time.

Business was probably half things that were altered and increased in value, and the rest things they bought and sold in the same form. They melted iron, cast it, sanded it, and pressured the molds for manhole covers, meter boxes, and such things that you see all over San Antonio. When he started, they were just beginning to learn how to weld. Most of the attachments were made with rivets. Many of the bridges in town were made by Alamo Iron Works, and they are "riveted to death."

After he became a machinist, Grier found he was good at making drawings for machinery and parts and soon was doing only that. When the war started, he went to work at Kelly Field, then the Philadelphia Navy Aircraft Factory. He moved around from one job to 
another, went to Chicago, to Panama, to Hawaii. When the war ended, he returned to Alamo Iron Works and started designing things in the machine shop. From there, he got into management of the company, and eventually became a stockholder and officer.

\section{Interview with Agnes Mahula}

Mrs. Agnes Mahula is part of the Margozewitz family and was raised in the Alamodome Project neighborhood. She is the granddaughter of Stephen Margozewitz. The family of Stephen Margozewitz, Sr., moved to San Antonio from Poland via Alabama and Indianola. Of their 12 children, four boys remained in San Antonio and, in 1925, founded a brass foundry in the back yard of property belonging to their mother. That was on Wyoming Street between Walnut and Cherry streets. Steve, Jr., lived next door.

Agnes lived in the front half of her grandmother's house (her grandfather died in 1917), while the grandmother lived in the back half. The house at Cherry and Wyoming streets was a rent house belonging to $\mathrm{Mr}$. Czernecki (spelled variously in documents as Czernecki, Czernicki, Czernitzky). There were three rent houses facing on Cherry Street that also belonged to him. The rent house next to the Margozewitz house at 722 Wyoming Street also belonged to Mr. Czernecki. He lived at 724 Wyoming Street. His daughter married William Mueller, who had a butcher shop in the HemisFair area. They lived in a large stone house south of the alley that ran east-west through the block.

Across the street, when they first moved there, was a grocery store run by the two Mayer sisters. The store ran from the railroad tracks to Wells Street. Along Wells Street there were just shacks where black people lived.

Agnes's father died in 1945, and she inherited his interest in the family business. She worked with her two uncles, Steve and Frank. They did well until they had a fire in 1969, which forced them to close the business. She then went to work for her cousins at another brass foundry until she retired in 1988.

She sold her property 16 years ago to Mr. Downing, who tore down the house and built a large warehouse for frozen foods. He never completely finished it. On the corner of Hoefgen Avenue and Wyoming street was a little restaurant. She remembers seeing it as she was walking to school.

Her grandfather worked for Alamo Iron Works, as did her uncle Steve. They quit there to start their business.

\section{Interview with Paul Guidry and Grace Dorrington}

Mr. Paul Guidry and his daughter Grace Dorrington were the operators of the New Corner Cafe. Mr. and Mrs. Guidry leased a cafe building at the corner of Wyoming Street and Hoefgen Avenue from the Lewis Equipment Company in 1949 and opened the Corner Cafe. They had previously owned a cafe at Villita and Presa streets, where the City Public Service is now. That one was started in 1946. Alamo Iron Works bought the site of the cafe at Wyoming Street and Hoefgen Avenue in 1967 or 1968, and they continued there paying rent to Alamo Iron Works.

They have always served the same kind of food. On Fridays they made shrimp creole, until shrimp became too expensive. On Monday they had roast beef and liver and onions. Tuesday was beef stew, cornbread, noodles, and sausage. On Wednesdays it was enchiladas, link sausage, and roast beef. On Thursday they had fried chicken, meat loaf, and roast beef; on Friday chicken fried steak, fried fish, and roast beef.

They bought their sausage from the Roegelein Provision Company when they were over on Commerce Street, on the other side of Hackberry Street. Mrs. Roegelein would let you go in the cooler and pick out your cut of meat, and go in the smokehouse and pick your sausages.

People came to the cafe from all over-the iron works, the freight depot, Leeway Freight Lines, General Hotel Supply. The workers who built HemisFair all came to the cafe. When the work on the tower would reach a certain point, they would have a party at the cafe, and they would eat and drink until midnight.

The night before they had to close the store in 1984, they had a big birthday party for Mr. Guidry. They had eight kegs of beer and 200 dozen tamales. Then 
the next day, 20 people showed up to help them move. They built a new store at 722 Wyoming Street in 1985.

The property across the street from Louis's Specialty once had a stone house on it (the Pauly house). It burned down in the 1950s, and Mr. Louie bought the whole thing and just kept it as it was until about four years ago. They took it apart and hauled away the stone.

\section{Interview with Cruz Peña Sellers}

Mrs. Sellers lived in the Runge Street area from 1929 until 1940. At first her family lived in a small house on Victoria Street, which was located on a large lot used by her father, Julian Peña, for a wood yard. Later, about 1936, they moved to 111 Runge Street. Her father sold wood and kindling to people who did not have gas or kerosene for heating and cooking. He also owned a truck, which he used to deliver wood and to move people, as well as to take black Baptists to Salado Creek to be baptized.

Mrs. Sellers attended Herff Elementary School in the neighborhood. The area contained a mixture of "gringos" (Polish, Jews, Germans), Mexicans, and blacks. There were mostly black people in that part of town, and a lot of Mexicans, and about three German families.

Mesquite wood was preferred for cooking, and old boards for kindling. Her father used to go out to Fort Sam and pick up lumber where they were tearing down buildings, bring it home, and sell it.

The Chung Sun Chinese Grocery was across Victoria Street from their first house. Later they moved a little east. There was a cleaning and tailor shop on the corner of Victoria and Runge streets. The Hardeman Barbeque place was across the street, where she used to go and buy barbeque because he always gave her a "pile-on." Hardeman's was a one-man operation, and he made his own sausage.

The San Antonio Casket Company used to be west of the Chung Sun Grocery and Mr. Hardeman, close to the railroad tracks. Her father used to deliver their caskets to the funeral homes. They later went into the upholstery business also.
There was another Mexican family living in the same block. They did plumbing and construction work. There was a black man named Valle who used to drive a truck for the Household Furniture Company. The United Fruit Company was on the railroad tracks. The kids used to go there, and the men working there would give us fruit.

There were a lot of people walking along the railroad tracks, rather than going along the street-it was easier and closer to go that way. There was a street along the tracks part of the way.

We used to buy our meats at the Ludwig Meat Market on Iowa Street. There were other grocery businesses through the neighborhood, on Nebraska and Cherry streets.

When they moved to the area in 1929 , there were houses on most of the lots along Runge Street. Most of them were owned by the Luchese family. A woman would come in a fancy car to pick up the rent. Our home belonged to Mr. Barnes. There were black and Mexican people living on Runge Street when they lived there. All the people were nice people, and there was no thought about people stealing or being afraid of anyone. Her parents moved back to Mexico in 1939, and she moved into town on Alamo Street. Her brothers and sisters married and stayed in San Antonio.

They traveled on the train, but not on the Southern Pacific. They took the Missouri Pacific to go to visit family in Mexico.

\section{Interview with Joe Chihal}

Mr. Chihal started working as a brakeman for the railroad in Louisiana. He was transferred to Texas in 1952. After serving in Alice, Houston, Lufkin, and Del Rio, he came to San Antonio in 1963. At that time, he was assistant superintendent for the San Antonio division. When the government took over the railroad, he was on loan to the government to help get adjusted. He stayed with Amtrack for about two years, then went back to his earlier job. His office was in the depot on Commerce Street. 
The Missouri Pacific was operating both freight and passenger trains out of the West Side when he came to San Antonio. The freight yard for the Southern Pacific was just off New Braunfels Street a little farther down from Commerce Street. All the trains were made up, and all the switches were done there. The only operations right around the passenger station were a few industries, such as Alamo Iron Works. The station was really just a passenger station, with offices on the second floor and passenger department on the first floor.

The freight station was in the white brick building south of the station. Eventually, the freight station closed, and they moved them over to the passenger station, leaving just the trucking department there. Then later they moved the trucking over to the east yard near the switching yard just off New Braunfels Street.

When he came here, mostly people came in the station to see the architecture. There were only two passenger trains operating. The railroad also served Alamo Iron Works, the San Antonio Machine and Supply Company, and Steves Sash and Door.

Chihal tells a number of interesting anecdotes about a barber, a shoeshine place, an old hotel, a cook. Locally and nationally famous dignitaries came through, including Henry B. Gonzales, Jackie Gleason, and Mamie Eisenhower. Also, a number of movies were made in the area and used the depot.

The Corner Cafe was a popular place to eat lunch, until the workers from HemisFair filled it up and you could not get in. He tells a bit about the makeup of the office he worked in and various people with whom he worked. Chihal took early retirement at age 55 in 1980. 


\section{References Cited}

Castañeda, C. E.

1942 The Mission Era, The end of the Spanish Regime. Our Catholic Heritage in Texas. Vol. V. Von Boeckmann-Jones, Austin.

Kendall, D. S.

1974 Gentilz, Artist of the Old Southwest. The University of Texas Press, Austin.

Pinckney, P. A.

1967 Painting in Texas; The Nineteenth Century. University of Texas Press, Austin.

San Antonio Express (SAE)

1897 [article concerning downtown development], 17 August.

1939 [article concerning downtown development], 31 December.

San Antonio Light

1940 [article concerning Victoria Courts], 16 October.

Steinbomer, R. A.

1983 Brickmaking in Texas. Texas Historical Commission, Austin. Copy on file at the San Antonio Conservation Society Library, San Antonio.

Steinfeldt, C.

1978 San Antonio Was: Seen Through a Magic Lantern. Views from the Slide Collection of Albert Steves, Sr. San Antonio Museum Association, San Antonio. 


\title{
Chapter 5 \\ San Antonio, Texas, 1900-1940: A Period of Mutual Aid
}

\author{
Shirley Boteler Mock
}

What's on the exterior has little to do with how successful we are-it's the spirit within us.

-Martin Luther King, Jr.

\section{Introduction}

This report examines the processes of ethnicity at work in the empowerment of African-Americans against the historical backdrop of San Antonio from 1900-1940. In 1992 Phase IV excavations of the Alamodome Project conducted by the Center of Archaeological Research (CAR) were initiated within a 17-block area (NCB 636) in the eastern section of San Antonio. Construction of the Alamodome forced many inhabitants of this neighborhood to vacate their homes at the onset of the project. By the time Phase IV of the archaeological project had been initiated, many of the small frame houses had either fallen prey to the wrecker or had been deserted to transients, leaving the discards of drug and alcohol use intermingled with an assortment of worn-out clothing, abandoned furniture, and the enduring plastic remains of fast food restaurants.

This study was originally intended to focus on the archaeological evidence of the small enclave of homes located on Runge and Martin Luther King streets in Denver Heights, excavated during Phase IV of the Alamodome Project; however, it soon became obvious that this evidence alone was inadequate to address more urgent questions. How did the AfricanAmericans who lived in these modest frame homes cope with discrimination and economic inequities during the early twentieth century? How did they interact with the rest of the African-American community and other groups? These questions could only be answered with a more in-depth examination of the life strategies of the broader African-American community in early San Antonio. To a great extent, however, this task was compromised by the lack of attention to the African-American in the historical reconstructions of early San Antonio (with the exception of research conducted by the Institute of Texan Cultures [ITC]). Moreover, comparative research also made it apparent that the San Antonio African-American community did not fit into the mold cast by the constructed histories of other urbanized African-American groups in the United States. Consequently, it was imperative to interview AfricanAmericans living during this time period to augment or clarify the archaeological and archival evidence. The recollections and information collected and cited in this paper are the results of interviews which E. L. Fly and Associates and I conducted with African-Americans.

Anthropologists must observe patterns in order to address stability and/or change as cultural processes. However, in minority groups these behavioral patterns are often subsumed and shaped by the social dimensions of ethnicity, the more subtle aspects of which are examined in the archaeological record and discussed in the first part of this paper. The early 
history of the African-American community in San Antonio, addressed in the second part of the paper, is a chronicle of adaptive strategies in articulation with, and in response to, a dominant Anglo-American society and increasing social circumscription. The final section of the paper examines these responses as a synthesis of ethnic values and Anglo-American institutions reorganized into a sustaining "mutual aid" system.

\section{Ethnicity and Empowerment}

African-American culture has been frequently subsumed under a "melting pot mythology" by some scholars (e.g., Glazer and Moynihan 1970; Schuyler 1980:vii; cf. Blackwell 1975; Blauner 1970:349; Deetz 1960; Staiano 1980), a term which obscures the multiethnic processes that often underlie cultural change. The study of assimilation, for example, often assigns to ethnic minority groups a passive role in cultural process and obscures the complexities of ethnic, class, and socioeconomic differences. In a more general sense, ethnicity can be defined as the "mechanism by which interest groups use culture to symbolize their within-group organization in opposition to and in competition with other interest groups" (Hodder 1979:452; emphasis in the original). Studies such as Barth's (1970) classic work have provided a framework from which to examine the maintenance of social boundaries between competing groups. However, I agree with McGuire (1982:169) who contends that these studies apply more to cultures than to ethnic groups in urban, industrialized cities.

Ethnicity is a two-way process that grows out of interaction, not isolation, and in this context, ethnicity is a dynamic process (e.g., Barth 1970; Staiano 1980:29) in which minorities are constantly restructuring their social boundaries with the dominant group. Ethnicity can also be exploited by a minority group for social or economic gain. History then, is not simply something that happens to people, "but something they make-within, of course, the very powerful constraints of the system in which they are operating" (Ortner 1984:159).

In many cultures ethnic groups maintain boundaries through the use of behavioral or material symbols. For instance, their outward manifestations such as clothing, ornaments, or architecture (e.g., Wiessner 1983; Wobst 1977) symbolized the "consciousness of a common past" (Blauner 1970:357) a situation which is present in modern day African-American society. However, ethnicity can be expressed much more subtly within an ethnic group, affecting the newspapers read, the religion espoused, or the values or standards by which the children are raised (Roosens 1989:18). Ethnic behavior may be so subtle or obscured by the constantly changing dimensions of class or poverty that few ethnic patterns of artifact use remain in the archaeological record of urban societies (Cheek and Friedlander 1990:36; see also McGuire 1982:164).

Strong boundaries, or segregation, not only serve the interests of the dominant group (McGuire 1982:171) but, as illustrated in this report, can be turned to the advantage of the minority ethnic group (McGuire 1982:161). For instance, as the archival and oral histories show, boundaries imposed by the AngloAmerican culture during the early twentieth century in San Antonio served as an impetus for solidarity and economic growth in the African-American community. While Anglo-American middle-class values, institutions, and economic structures were incorporated by African-Americans, they were transformed into new contexts of use as strategies of survival; into an ethos of mutual support.

\section{Archaeology and Ethnicity}

Archaeological excavation of the NCB 636 area provided an opportunity to gather data on early African-American settlement in San Antonio, thus supplementing the archival data and oral interviews. As a result of preliminary archival investigations, the field strategy focused on Area 1 (the area formed by Runge, Cherry, and Durango streets) and Area 2, (the area surrounding Lots $C$ and $D$, and the central sections of Lots A8 and 7) (Volume II). Many of the houses had been removed prior to the arrival of the excavation teams from CAR.

Both the archaeological deposits and architecture in Area 1 dated from ca. 1856 to the present day; however, this area was singled out for more intense investigation because deed records indicated a predominant African-American population in the early part of the twentieth century. Race designations are not 
given in the census reports subsequent to 1920 ; therefore, African-American occupancy at a specific residence, unless verified by oral informants, could not be ascertained. However, oral informants state that $\mathbf{8 0}$ percent of the Denver Heights area was AfricanAmerican (Jones, Oral History Interview, 1991).

Early land surveys and titles indicate that the entire block under investigation was purchased by Bernard J. Mauermann in 1874. In 1918 his son, Gus Mauermann, subdivided the property he had inherited into 19 small lots and Runge Street was platted (Bexar County Deed Records [BCDR], Bexar County Courthouse, San Antonio, Texas, 568:241). From 1921 to 1926, Gus Mauermann built 19 houses on the small parcels of land, seven of which, although considerably altered by the subsequent owners, were remaining at the time of the Alamodome Project. Runge Street houses razed prior to Phase IV were photographed and mapped.

Traditional approaches to examining ethnicity in the archaeological record use indices such as architecture, furniture, privies, dwelling dimensions, the use of available space, settlement patterns, household items, dietary remains, and refuse disposal (e.g., Cheek and Friedlander 1990; Evans 1980; Staiano 1980; Vlach 1986). Patterns obtained from this data would be compared to household patterns of other ethnic groups located in a similar working class neighborhood to elicit different boundary maintenance strategies. Three trenches (A, D, and E) were placed in Area 1 to provide maximum recovery. In Area 2, northwest of Area 1 (NCB Lots C, $D, 7$, and 8) two trenches (B and C) and four 2-x-2-m test units were placed. Deposits from Area 1, with the exception of 1231/2 Runge Street, fell within the projected 1920 to present-day time frame. Deposits in Area 2 (Lots 1231/2 and 125) ranged in date from the late 1800 s to present day. The earlier deposits relate to structures that were in place prior to the subdivision of the Mauermann property and platting of Runge Street. Deposits from
Trench B, for example, as might be expected, yielded a variety of materials representing different time periods. A small saltbox-style house at $1231 \frac{1}{2}$ Runge Street was probably brought in from another location close to the site. City records note that $\mathrm{Mr}$. Mauermann constructed the house in 1924, a date that does not correlate with the architectural style of the building, which dates to around 1880. Janet Penn Baity (personal communication 1993), who lived at 127 Runge Street as a child, recalls this house being placed on the back of Nebraska Street (later changed to Martin Luther King Drive [MLK]), Lot 120, by Ophelia MacKinnon.

The small houses investigated in the study area located on Runge, Cherry, and MLK streets are small frame bungalows (Figure 5-1), typical of small houses ca. 1880-1930 (Lancaster 1986). Certainly the most noticeable feature of the frame houses in the neighborhood was their architectural monotony, each with a gabled front and exterior of board and batten siding. The houses were placed at the front of the lots facing Runge or Cherry streets, with very small front yards in comparison to the older houses built by Anglo-Americans, subsequently rented or purchased by African-Americans. Backyards were also small by comparative standards, with little room for gardens or storage areas.

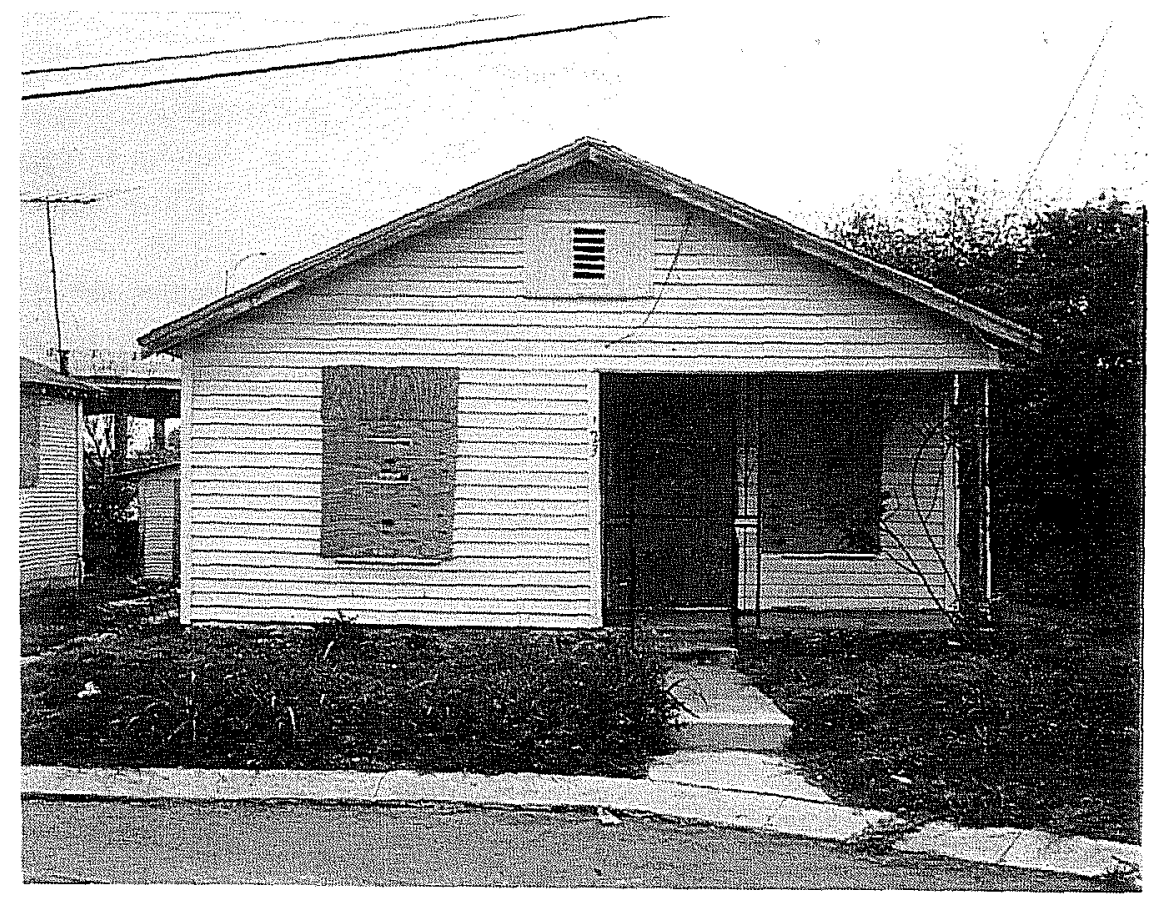

Figure 5-1. Small frame bungalow at 123 Runge Street, 1990. 
Similar to vernacular versions of the $T$-shaped bungalow, the houses were actually one single core unit of kitchen, dining, and living room with a oneroom wing, and a back and front inset porch (e.g., Gottfried and Jennings 1985). Heat was provided by an interior brick chimney with stove pipe openings into the kitchen and dining room (Inman, Oral History Interview, 1992). Two front entrances off the inset front porch offered the renters/owners the opportunity to sublet rooms in the house to supplement incomes. Therefore, the single kitchen served the needs of either extended-kin units or owner and boarder. Although originally serving as a functional architectural feature for the lower class, the two-door enclosed-porch model became typical of mass-produced houses in the twentieth century (Amy Dace, personal communication 1992) and can still be found throughout the Denver Heights area.

The small rental houses on Runge were among a multitude of architectural styles in the Denver Heights area, only a few of which were included in the Phase IV NCB 636 investigations of the Alamodome Project. They included Victorian-influenced, L-plan houses; Texas Victorian T-plan houses; single-family cottages; bungalow-style houses; and one German stone house left standing at the time of excavations, the Demazieres house. Although many of the early houses were built by Anglo-Americans, some middle-class African-American families built their own houses in the early 1900s (Inman, Oral History Interview, 1992) as the Denver Heights area spread to the east.

Versions of the more humble, vernacular-type, "shotgun" house were represented on Hackberry Street next to the Mt. Zion First Baptist Church, according to the Reverend Claude Black (Oral History Interview, 1992). The small, narrow shacks, built by AngloAmerican absentee landlords, were located in pockets throughout Denver Heights: in Pablo Alley in Block 620 (Figure 5-2) and around

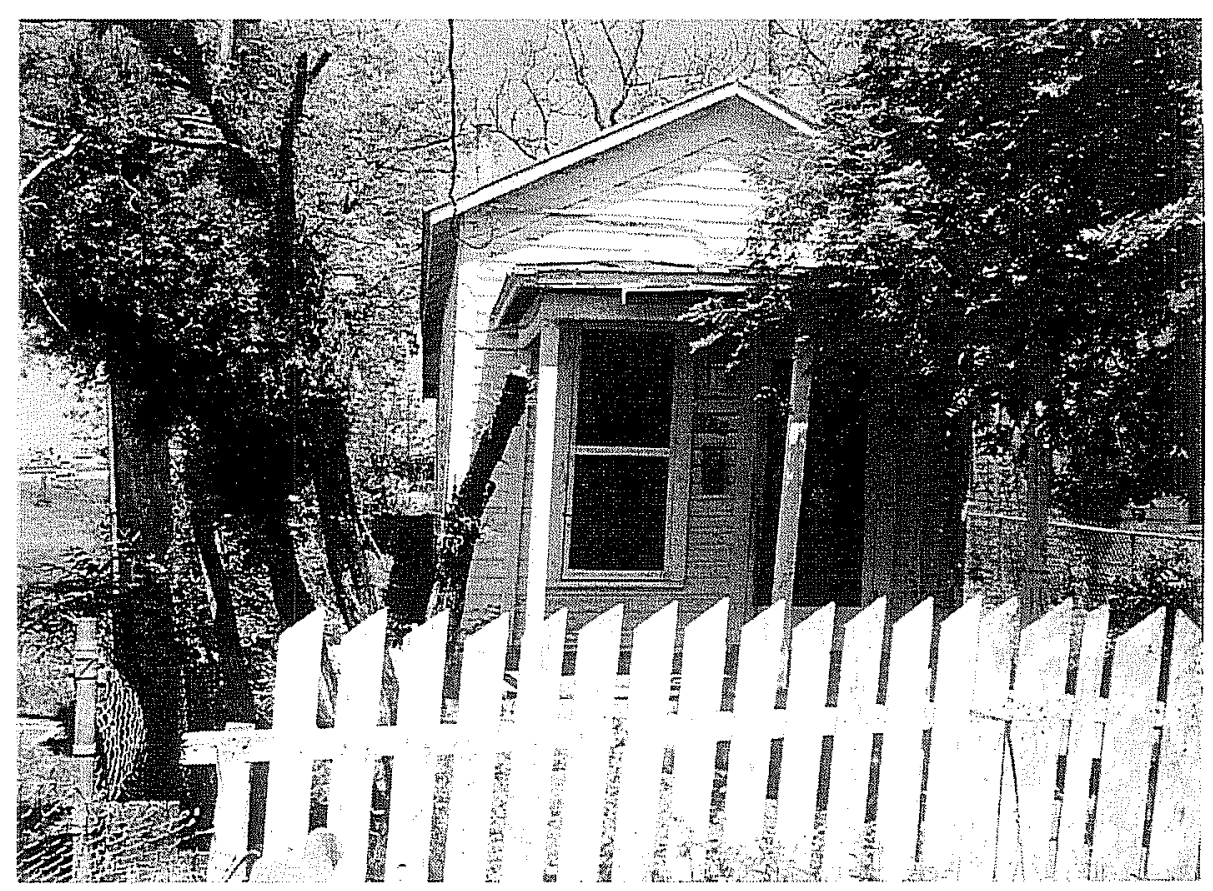

Figure 5-2. Shotgun house at 139 Pablo Alley, 1990.
Commerce Street and north of Commerce Street, near the railroad tracks. Today, only a few of these houses are left on the east side, and due to architectural alterations, many can hardly be recognized (Clyde Glosson, personal communication 1992).

As late as 1970, a large percentage of AfricanAmerican housing lacked basic plumbing such as bathtubs and toilets (e.g., Blackwell 1975:143). However, this lack of facilities was true of other ethnic poverty and low socioeconomic status. Runge Street residents in San Antonio did not have such amenities when the houses were constructed in the 1920s. Architectural modification of the Runge and Cherry street houses through time included the enclosure of the inset back porch for indoor plumbing and flush toilets in the late 1930s.

According to the Reverend Claude Black (Black, Oral History Interview, 1992), bathtubs were a sign of affluence when he was growing up in the Denver Heights area in the early 1900 s. Galvanized bathtubs were stored and used on the back porch and water was obtained from an outside spigot. More affluent homes had hot water piped into the bathroom. Another sign of affluence, observes the Reverend Black, was to have more than one bedroom because it afforded more privacy. groups in San Antonio, suggesting it was a condition of 
Clearly, neither the architecture nor the archaeological record showed qualitative or quantitative patterns that could be assigned to ethnic behavior. This absence may be due, in part, to the admixture of ethnic groups in the area through time and space, thus leveling out any material evidence of distinctive ethnic behavior. Alternatively, as noted above, certain aspects of African-American culture may not differ from those of other interacting ethnic groups, as they attempt to empower themselves by adopting behaviors or symbols of the dominant class.

\section{Denver Heights: Stability and Change, 1900-1940}

With the arrival of the Southern Pacific Railroad in 1877, economic emphasis in the city of San Antonio shifted from small, farming enterprises to commerce and manufacturing. Growth east of the Southern Pacific railroad tracks at this time was due, in part, to the construction of the new railroad terminal on East Commerce Street in 1903. Among the many ethnic groups represented in San Antonio were populations of German, Jewish, Irish, Polish, Indian, Mexican, and Chinese, in addition to African-Americans. Industrialization and the lure of wage labor lured many of these early migrants to San Antonio from unprofitable, rural sharecropping farmsteads. In 1900 the AfricanAmerican population had risen to around 7,450 in San Antonio, compared to 3,036 in 1880 (Truss 1986). However, the percentage of black urban population was still small when compared to other Texas cities (Barr 1973:164), a significant factor in its intergroup ethnic relationships and demography.

As the city of San Antonio expanded, the black population spread from the earliest community, the Baptist Settlement, east across Walnut Street and north to Crockett Street. In 1916 the area previously known as South Heights became officially known as Denver Heights. The petition for the change states that the "name 'carries with it the interesting, and grateful recollections connected with the city of that name"" (San Antonio Express News [SAEN], 5 January 1916:14). The Reverend J. C. Glosson (Oral History Interview, 1992) remembers that Denver Heights encompassed an area that included the old Douglas High School between Iowa and Hackberry streets where people owned small homes; the area around
Burnett, Dawson, Menard, and New Braunfels streets; and the two or three blocks off of East Commerce Street to Centre Street. The Reverend Claude Black (Oral History Interview, 1993) observes that the more affluent African-Americans owned homes bounded by New Braunfels and Nolan streets.

Early settlement on the east side of San Antonio, according to documents and oral histories, was characterized by the lack of a clear spatial separation between culturally distinct ethnic groups relative to later times. Social boundaries based on ethnicity existed, but African-Americans and other recently arrived ethnic groups such as Germans and Poles lived side by side in this rather heterogeneous enclave. Facing similar dilemmas in terms of adaptation, many of the newly arrived groups interacted on a mutually supportive economic level according to oral histories (e.g., Black, Oral History Interview, 1992; Glosson, Oral History Interview, 1992; Inman, Oral History Interview, 1992). Lillian Sutton-Taylor, who lived at 430 Cherry Street as a child, recalls the heterogeneous mixture of ethnic groups in her neighborhood. She notes the presence of "outsiders" as well as extended family members in birthday festivities and recounts playing with the Jewish children who lived next door (ITC files, Record II:20-27). Emphasizing the distinct lack of "color consciousness" in her early middle-class neighborhood, Lillian Sutton-Taylor also contends that as time progressed the situation worsened. Another early San Antonio resident, Thomas Cox, recalls playing with German boys in his neighborhood (San Antonio Register Milestone Edition [SARME] 1991:5) while the Reverend J. C. Glosson (Oral History Interview, 1992) remembers playing ball and going to "picture shows" with Anglo-Americans. However, he adds that once the movie house was reached, AfricanAmerican children in the group were forced to go and sit in the "colored section."

Despite the heavy hand of Jim Crow outside the community, archival investigations in the Runge and Cherry streets area support the argument that distinct ethnic boundaries, at least in terms of where one lived, were not the norm in early twentieth-century San Antonio. The interpretations offered, however, are based on limited and often incomplete archival information. Structures such as the Demazieres house built in 1856-occupied by Mrs. Lena Rotzler, a German-American, until 1933 (City Directories [CD] 
1931-1935)-were located next to a residence at 706 Walnut purchased and occupied by Richard White, an African-American bellboy for the Menger Hotel, in 1903 (BCDR 219:310). Similarly, a residence located at 116 Nebraska (MLK) was occupied by Mrs. Louise Lamm, the Anglo-American widow of Joseph Lamm, until her death ca. 1924 (BCDR 783:606). A neighboring structure at 120 Nebraska (MLK) was purchased by an African-American family, Boyd and Hattie Thorton, in 1924 (BCDR 752:424) and occupied until 1946. The property at 130 Nebraska (MLK) was occupied and owned by two Anglo-American families until 1920 (BCDR 34:117, 119:299; CD 1919-1920), when it was sold to an African-American couple, Sam and Emiling Andrews (BCDR 590:105, 569:298, 569:297). Mr. Andrews worked as a porter for then A. B. Frank Company (BCDR 590:105, 569:298, 569:297).

Shifts in the attitude of whites toward blacks in Texas and more segregated settlement patterns in the 1920s were probably heralded by the revitalization of the $\mathrm{Ku}$ Klux Klan in 1915. Significantly, this rebirth of the Klan was contemporaneous with the release of The Birth of a Nation, a film which strongly condemned Reconstruction and blamed African-Americans for a majority of the nation's troubles (John Slate, personal communication 1992). Mob violence against AfricanAmericans in Texas reached new proportions, attesting to the deteriorating racial atmosphere. Texas ranked third in the nation in lynchings of African-Americans from 1900-1910 (Barr 1973:136). In 1916 outbreaks of violence between black soldiers and white civilians in San Antonio are reported (Kirven 1974:115). The threatening presence of African-American troops in San Antonio following the outbreak of World War I in 1918 may have fanned the fires of racism (Kirven 1974:115).

A 1918 edition of The San Antonio Inquirer (SAI), the African-American newspaper, noted that 17 blacks had been lynched between 1917 and 1918 (SAI, 10 August 1918a:1). The San Antonio Express News, a prominent Anglo-American newspaper owned by Mr. George W. Brackenridge, a well-known philanthropist and advocate of African-American causes, not only publicly endorsed the newly formed National Association for the Advancement of Colored People (NAACP), which actively sought the repeal of the Fourteenth and Fifteenth Amendments to the
Constitution (Kirven 1974:101), but also set aside a $\$ 100,000$ reward for the capture of parties responsible for lynchings (SAI, 10 August 1918b:1). Ku Klux Klan activity, however, continued into the Depression years. A 1931 edition of the San Antonio Register (SARME 1991:5), successor to the San Antonio Inquirer, disclosed that a "crudely constructed wooden cross about five feet high, wrapped in cloth and rags" was burned on the lawn of Charles Bellinger, a powerful and wealthy black leader, who lived at 518 South New Braunfels Avenue in Denver Heights (SARME 1991:2).

\section{The Other Side of the Tracks}

Settlement in San Antonio took on different configurations as the twentieth century progressed and the Depression ended. Anglo-Americans began migrating from the inner city to establish exclusive residential suburbs to the north. The older homes in Denver Heights were rented or sold to minorities such as African-Americans, thus paving the way for more circumscribed boundaries based on ethnicity and socioeconomic status. The timing of this exodus is supported by documents noting the transfer of AngloAmerican properties bordering Nebraska Street (MLK) to African-American families. The eight small structures in the Runge and Cherry streets area were constructed in 1921, 1924, and 1926 as black rental properties. In 1921 a structure was erected at 731 Cherry Street (NCB 636, Lot Q) for or by Henry and Adelia Grant, an African-American couple (CD 1921-1922).

The availability of the older housing was probably due to its deteriorating condition and close proximity to the noise and pollution from the Southern Pacific Railroad and businesses such as Alamo Iron Works and Steves Lumber Yard. Nevertheless, proximity to jobs and the availability of transportation by streetcar made this area a desirable location for many African-Americans. Undoubtedly, the proud new owners of these moderate homes paid exorbitant prices and excessive interest rates for houses in Denver Heights compared to Anglo-Americans (e.g., Johnson 1932:97).

Once a house was purchased, occupancy was fairly stable among middle-class African-American families living in the Runge Street area. In fact, a good proportion of the homes remained in the family after 
separation or the death of the male breadwinner, retained by the wife or their children. For example, the residence at 127 Runge was owned and occupied from 1936-1959 by Mrs. Myrtle Thomas, a maid, who inherited it from Irene Thomas, according to the city deed records. Mrs. Irene Pettit, also a widow, owned and occupied the residence at 125 Runge for 13 years from 1934-1947 (BCDR).

Census reports do suggest frequent turnovers in occupancy among some African-Americans who rented houses in the Runge Street area during 1927 and 1937. These renters were typically African-American males or females employed in low-status, unskilled jobs such as cooks or domestic servants who would have been the first employees to be laid off during the Depression. Many of the occupants were also probably young families who had not acquired the capital to purchase property. Therefore, this seeming transience should not be considered an ethnic characteristic of African-Americans but an indication of the limited opportunities for unskilled laborers. By 1930, the Denver Heights area is lauded by one old-timer as becoming "the haven of San Antonio's middle and upper-middle class Blacks . . . along with the German families, resided Black waiters, porters, and the lieutenants of Charlie Bellinger" (SARME 1991:5). I suspect however, that this interdigitation of ethnic groups into the 1930s was due to the fact that the older descendants of early German landholding families were retaining their homes.

A class structure came into being, according to one long time resident, not only defined "by where you lived" in Denver Heights, but "what you did for a living." Among the socially elite blacks were the "Pullman porters and waiters working for the railroad, the Menger Hotel, and the Old South Restaurant" (SARME 1991:5). Pullman porters appear to have been at the top of the class list according to other old-time residents, because this was as far as blacks could go in the railroad industry. Other top-ranked jobs included hotel waiters and bell boys because of the opportunity to obtain tips (Glosson, Oral History Interview, 1992).

Low-income, ramshackle shotgun housing destroyed by city expansion, existed further north of Commerce along the railroad tracks (Jones, Oral History Interview, 1990; Glosson, Oral History Interview, 1992). Here lived the poorer, more transient African-
Americans, who had less steady jobs working for the city, the lumber yards, or as clerks in small stores (Glosson, Oral History Interview, 1992). As A. C. Sutton (1990:5) observes:

Blacks lived there in those . . . because they were cheap living. And lot of times they would work for the railroad or someone and they would find a place for them to live close to the jobs and that kind of was a philosophy of the earlier business to make sure that their employees were close around. So they had those little huts up and down the tracks where people lived.

The cordoning off of African-Americans from the larger Anglo-American community created an "internal colony" (Blackwell 1975:139), surrounded by a dominant Anglo-American population who owned the modes of production. Thus the axiom "In the modern city, a man is where he stands" (Lofland 1973:82) became a reality. If an upwardly mobile, middle-class African-American wanted to move, he or she was prevented by discriminatory residential codes such as protective covenants prohibiting resale of houses in certain residential areas (Rice 1971:251). Even veterans returning from World War II had a difficult time purchasing a house in San Antonio (Davis 1978:40). Part of the problem lay in the lack of African-American banks; by 1928 only five black banks existed in Texas, thus discouraging AfricanAmericans with little ready capital to invest in property (Rice 1971:195). Therefore, a situation was created, as the Reverend Claude Black (Oral History Interview 1992) observes, where "the black janitor lived side-byside with the principal of the school." This ascribed residential pattern acted as a sort of leveling mechanism despite the class distinctions within the African-American community thus contributing, in some respects, to group cohesion.

\section{Jim Crow and the American Dream}

The unspoken intentions of African-Americans to fit into the American way of life during the early twentieth century is poignantly expressed in the exhortations of African-American leaders urging blacks to support the World War I efforts (SAI, 20 July 1918c:1). Although many patriotic African-Americans heeded the call to bear arms, they were segregated into 
black companies and generally relegated to nonleadership roles. Black nurses were sent to army camps overseas (SAI, 27 July 1918d:1) despite the fact they were denied the Texas board certification accorded to other nurses because of their "color" (J. C. Glosson, personal communication 1993). One of the black military regiments stationed at Camp Travis, located on what is now Fort Sam Houston, was relegated to entertaining the troops with minstrel shows (SAI, 20 July 1918c:1). Unfortunately, however, the lot of African-Americans was not improved by their noted bravery and distinction in the war efforts (Kirven 1974:123).

Certainly, part of the change in the white attitude toward blacks was related to population growth and the influx of new immigrants. In 1920 the population of San Antonio had grown by 67 percent, but in 1930 a considerable growth of 43 percent was noted, compared to only 9.5 percent during the height of the Depression (Davis 1978:38). Much of the population growth was a result of the emigration of MexicanAmericans due to social unrest in Mexico between 1900 and 1930 (e.g., Davis 1978:40). By 1929 the Mexican-Americans and African-Americans were firmly entrenched on the bottom of the class scale (Davis 1978:39). The voice of black San Antonians, the San Antonio Register (1936), heralds the influx of Mexican-American immigrants into the Denver Heights community in its 1936 advertisements promoting Mexican restaurants and food products such as masa flour, Gebhardt's chili powder, and pinto beans.

A crucial state in the development of segregation in Texas was the implementation of segregation ordinances, called "coach laws," on street cars in the early 1900 s. These laws also included separate waiting rooms for black travelers (Rice 1971:145-147). Augusta Whittier (personal communication 1993) recalls the coach laws created problems for AfricanAmerican travelers. Her husband, Charles, knew the owner of the Southern Pacific Railroad and would get the Whittiers a special drawing room on the train; however, they were not allowed to go out of the room and had to have their meals sent in.

Boycotts in San Antonio were organized by AfricanAmericans, led by Mr. J. A. Grumble, a wealthy mail clerk for the Southern Pacific railroad who refused to ride in the inferior cars reserved for AfricanAmericans (Glosson, Oral History Interview, 1992). These boycotts coincided with the rise of the San Antonio NAACP, of which Mr. Grumble became president in 1926. Mr. Grumble later became a founder of the Colored Library Association.

Poverty became even more pronounced with the advent of more stringent and rigid segregation laws (Rice 1971:265) in Texas. Blacks (and MexicanAmericans) suffered increased racial prejudice by being denied services at private hotels, eating establishments, and mercantile establishments. In San Antonio, blacks were segregated on one side and whites on another at favorite eating spots such as the Sam Hoo Cafe (Jones and Runnels, Oral History Interview). One long-time San Antonio resident and early civil-rights activist, the Reverend J. C. Glosson, Sr., born in 1907, recalls that some establishments further north on Commerce Street would not wait on blacks. He remembers a shoe store located on Houston Street that would ignore blacks if they sat down and wanted to try on shoes (Glosson, Oral History Interview).

African-Americans were forced to use segregated areas of local hospitals and black doctors were not permitted to operate in white hospitals (ITC files, Sutton-Taylor 1977:R.I:I). The Reverend Claude Black, born in San Antonio in 1916, recalls that he was born at home because blacks could not go to white hospitals. However, Charles Bellinger (Figure 5-4), the African-American millionaire, on whose front lawn the cross was burned, donated substantial sums of money to Santa Rosa Hospital, thereby procuring his own private ward at the hospital to accommodate the needs of his family and those of the "colored T. B. patients" (ITC files, Sutton-Taylor 1977:R.II:11). Discriminatory practices created a dilemma in health care for many African-Americans. Consumption, pneumonia, diarrheal ailments, malaria, and typhoid were some of the more common health problems due to substandard care under the "separate but equal" laws. Mrs. Sutton-Taylor (ITC files, 1977:R.I:20) notes that "consumption or tuberculosis was like cancer is today." The prominence of advertisements in the San Antonio Inquirer promoting health care products and home remedies during the early twentieth century, is undoubtedly due in part to the lack of practicing African-American doctors. There was a ratio of 4,970 


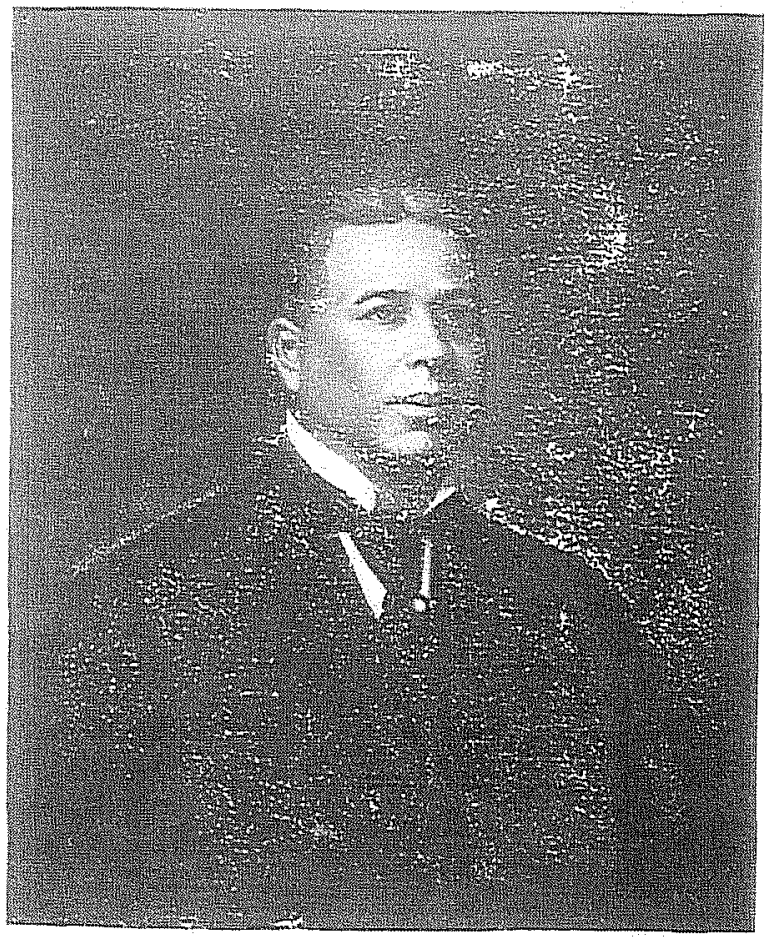

Figure 5-3. Charles Bellinger. Courtesy of

Dr. Ruth Bellinger.

black Texans for every black physician in 1932 . As late as 1900 , the death rate for blacks in San Antonio was 22.7 per 1,000 (Rice 1971:261).

Attempts were made to address this critical need for health care by conscientious black citizens such as Dr. Charles A. Whittier. In 1931 Dr. Whittier founded the Whittier Clinic, located at the corner of Crockett and Hackberry streets to help serve some of the medical needs of the black community. The clinic also provided training not available elsewhere to black interns. Dr. Whittier later became the first AfricanAmerican doctor on the Santa Rosa staff after it was integrated (Mrs. C. A. Whittier, personal communication 1993). In 1925 a small health care clinic run by Mrs. Jemima Elizabeth Lee (Figure 5-4) was established at 716 Sherman Street to provide some medical and dental services. Additional staff members were Dr. Johnson, Dr. Haywood, and Dr. Walter (Mrs. C. A. Whittier, personal communication 1993). Health concerns were also addressed by the Volunteer Health League which was founded by G. J. Sutton (ITC files, Sutton-Taylor 1977, R.I:20) to raise funds to send tuberculosis patients to Kerrville, Texas, for treatment.
Discriminatory practices even extended to forms of entertainment and recreation. Access to San Antonio's world-famous zoo was denied to African-Americans (Davis 1978:40). One of the foremost black poets of the early twentieth century, J. Mason Brewer, describes the traumatic experience he had in attempting to take his young son to the zoo after visiting the sacred shrine of Texas freedom, the Alamo. Upon attempting to pay for a pony ride, the zoo keeper responded, "This ain't for you," to his son (Brewer 1947:17). Sapper (1979:491) cites Brewer's (1947:17) poem on the occasion.

He looked up at the keeper, And hung his proud head down And took a pocket mirror out And saw that he was brown.

In 1926 blacks obtained a separate library (ITC, Bellinger 1984:21) through the efforts of the Colored Library Association and the Negro Citizens Executive Committee, urged on by the support of spokesmen such as Charles Bellinger. The library, housed in two frame buildings, was the scene of community dances, commencement exercises, and political meetings.

Even the dead did not escape the persistent watchdogs of Jim Crow. African-Americans, if they had been able to purchase a burial policy or plot from one of the fraternal organizations (Sutton, Oral History Interview, 1990) or insurance companies, were relegated to certain portions of city cemeteries $\# 1, \# 2$, or \# 3, on the backside of Commerce Street (Black, Oral History Interview, 1992; Glosson, Oral History Interview, 1992; Inman, Oral History Interview, 1992). The Odd Fellows, UBF, and Eastern Star lodges had their own cemetery ". . . all because they believed that there should be a place where they should be able to bury their dead" (Sutton, Oral History Interview, 1990:7).

During the 1930s and 1940s, famous AfricanAmerican artists such as Duke Ellington performed at the Majestic in downtown San Antonio to white audiences. After the main performance, the artists would return to play for black audiences in the small clubs of the east side. Promotions in the black newspaper urged patrons to come dance to the "Hot Hi-De-Hi Harmony" of groups such as Cab Calloway and his original Cotton Club orchestra when they 


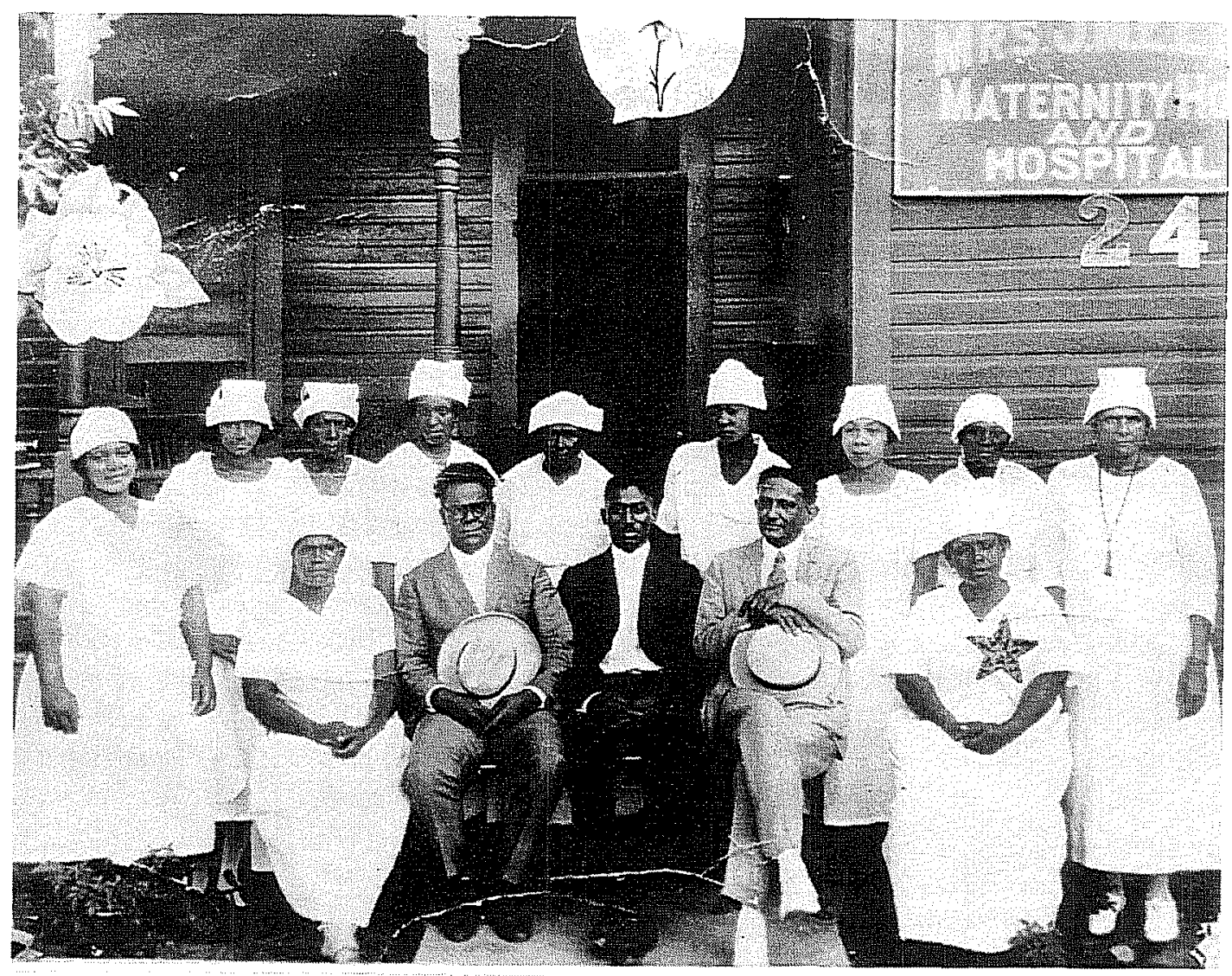

Figure 5-4. Hospital staff of Mrs. J. E. Lee. ITC collection.

played at dances at the Library Auditorium on Hackberry Street (San Antonio Register [SAR], 5 May 1931:7) or to "jam" at clubs such as the Avalon Grill or the Mona Lisa Club, drawing white aficionados who admired the soulful sounds of black music. Another popular club for entertainment was the Old Bill Wood Hall, located next to the railroad track (Sutton, Oral History Interview, 1990). An early edition of the San Antonio Register (24 January 1936a:1) heralds the appearance of Joe Robichaux and his New Orleans Rhythm Boys at the Avalon Grill. Another popular nighttime spot was the Leonard Roof Garden. Boxing matches and floor shows also provided entertainment on the east side (Jones and Runnels, Oral History Interview, 1990). Prominent local bands included the American Woodmen Band, the Grand Union of Colored Labor Band, and the $\mathrm{K}$ of $\mathrm{P}$ Band who performed at a membership drive of the Mt. Zion Baptist Church in 1929 (Pickett 1971:12). In 1936, the Leon Theatre opened on South Pine Street, featuring the Littlest Rebel with Bill Robinson and Cab Calloway (SAR, 17 April 1936b). The balconies of movie theaters such as the Palace were reserved for "colored" folks. Augusta Whittier (personal communication 1993) recalls that her husband, the benevolent Dr. C. A. Whittier, proudly refused to attend or take her to an event for which he was required to pay a fee to go in the back door or up the fire escape. White theaters were the Majestic and the Empire while the Cameo was the theater reserved for blacks. Mrs. Henrietta Stevenson (personal communication 1993) remembers similar strong feelings in her family about indignities suffered in a white world. She recalls pleading to see Gone With the Wind, which was a movie considered to be a spectacular event because it had a black actress, even if she was a "mammy."

Such obstacles undoubtedly played a role in stimulating the formation of amateur theater groups such as the San Antonio Negro Little Theatre, founded in 1931 by actor John W. Hemmings and his wife, the director Myra D. Hemmings (Mrs. Henrietta Stevenson, personal communication 1993). A 1936 edition of the San Antonio Register (10 April 1936c:6) notes the 
appearance of Mr. Tom Sutton in the Ninth Guest at the Library Auditorium. One significant portent of the nascent civil rights movement was the opening of Paul Green's Tragedy, In Abraham's Bosom in 1932 (Sapper 1979:495). The play, according to an anonymous reviewer, "involves the question that is nearest the heart of every American negro-his struggle and his sacrifices for education and enlightenment in the midst of ignorance, superstition, and prejudice" (SAR, 16 May 1932:2).

Such auspicious events also reflect the increasing surge of consciousness to preserve African-American culture by many enlightened African-Americans. In a 1936 edition, The San Antonio Register's front page highlighted a well-known actor who called for a "Negro People's theatre that can restore meaning to black culture which has been stifled, repressed, and misrepresented by Broadway and Hollywood" (SAR, 17 April 1936d:5).
Pacific Railroad. The Reverend J. C. Glosson's father, who as a youth served as a railroad painter, later became a "stationary fireman" for the Southern Pacific Railroad. Upon the death of the supervisor of his shop, the Reverend Glosson recalls that his father took over the supervisor's job overseeing a multi-ethnic group of workmen. However, despite Mr. Glosson's excellent qualifications for the job, he was soon "let go" by his employer because of the workmen's complaints about having to work for a black man (Glosson, Oral History Interview, 1992).

Other jobs available to African-Americans included construction work, laborers, welders (Figure 5-5), and freight loaders (Jones, Oral History Interview, 1990; Sutton, Oral History Interview, 1990). James H. Carter, born in 1895, and a current resident of San Antonio, had the unusual job of driving a team of mules delivering telephone poles from Austin to San Antonio (Pickett 1971:10). Other major opportunities for African-Americans were found in occupations such

\section{"Getting by" or "Getting Ahead"}

By the middle of the twentieth century, rapid industrial growth had brought an economic boom to the Alamo City. African-Americans, perhaps partly because of their ability to speak English and willingness to accept low wages, were in demand as unskilled laborers. AfricanAmerican males occupied a special niche in the division of labor, finding steady work in the transportation industry close to their homes, holding jobs such as baggage handlers, porters, brakemen, engineers, and railroad mechanics. Mr. John Inman (Oral History Interview 1992), a barber and prominent civic leader in San Antonio, had two brothers working for the railroad: one a Pullman porter, the other a boiler tender for the Southern

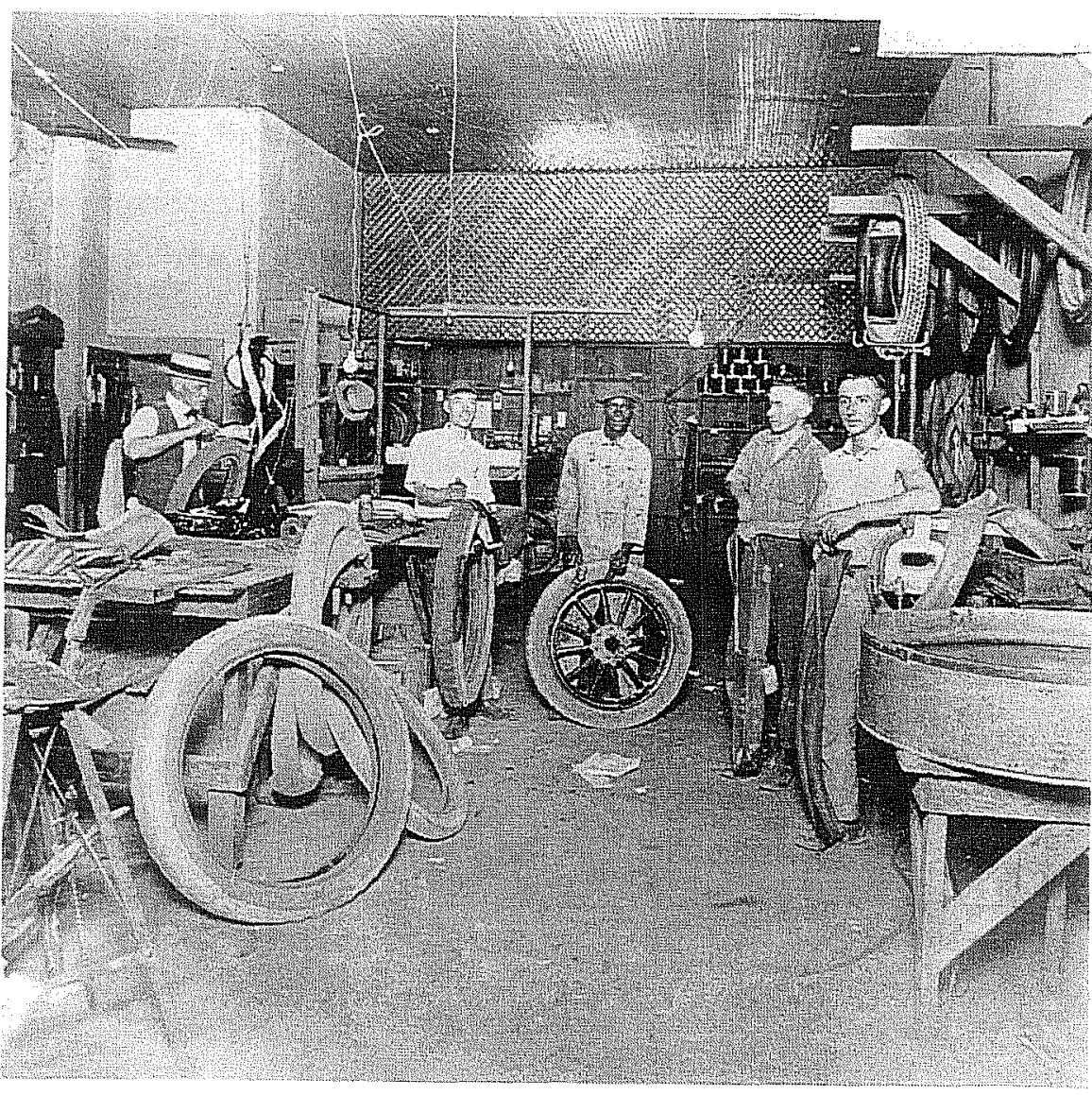

Figure 5-5. Wheeler Auto Supply, 1918. ITC collection. 
as hack services (hauling luggage or freight in from the trains), or constructing and maintaining train tracks (Jones and Runnels, Oral History Interview, 1990). African-Americans also worked as cooks (Figure 5-6), carpenters, and household employees (Figures 5-7 and 5-8). In addition to the poor representation of doctors noted previously, lawyers were rare in the professional work force. In 1936, for example, only three African-American attorneys were practicing in San Antonio (Sapper 1979:1990). Census records of San Antonio support the frequency of these low-paying occupations in the Runge Street area of Denver Heights. Renters between the years 1922-1924 include a cook for the Southern Pacific Railroad, two porters for the Pullman Company, a salesperson for Joske Brothers Department Store, a barber, a Southern Pacific shop worker, an Alamo-Peck Furniture Store employee, and an Alamo Iron Works laborer (CD 1922-1924).

Railroad jobs for the Southern Pacific seem to have attracted numerous blacks to San Antonio because of the railroad's reputation for providing steady work and good pay compared to other occupations (Glosson, Oral History Interview, 1992). However, due to the popularity and status of railroad jobs, African-Americans could easily be replaced if they demanded higher wages. This subtle form of discrimination kept ambitious, hard-working blacks in a "holding pattern" in terms of job advancement. Railroad work, moreover, was not without its dangers. On March 18, 1912, an explosion occurred at the Southern Pacific Shops in which 15 workers were killed and many more injured (SAEN, 18 March 1912). The machine and blacksmith shop, the tin and copper shops, and a large part of the roundhouse were destroyed.

World War I (1914-1918) had offered a stimulus to black businesses and aspiring black entrepreneurs despite the slowing down of the economy during the Depression in 1929 and the scarcity of jobs. W. H. Leonard and his wife Belle, an African-American entrepreneurial couple, operated the successful Leonard's Pharmacy on the corner of Pine and Iowa streets in 1925 (Figure 5-9). Other modes of enterprise open to ambitious and industrious African-American citizens included ownership of barber shops, saloons, boarding houses, and grocery stores catering to blacks, prohibited from shopping elsewhere (Rice 1971:194).

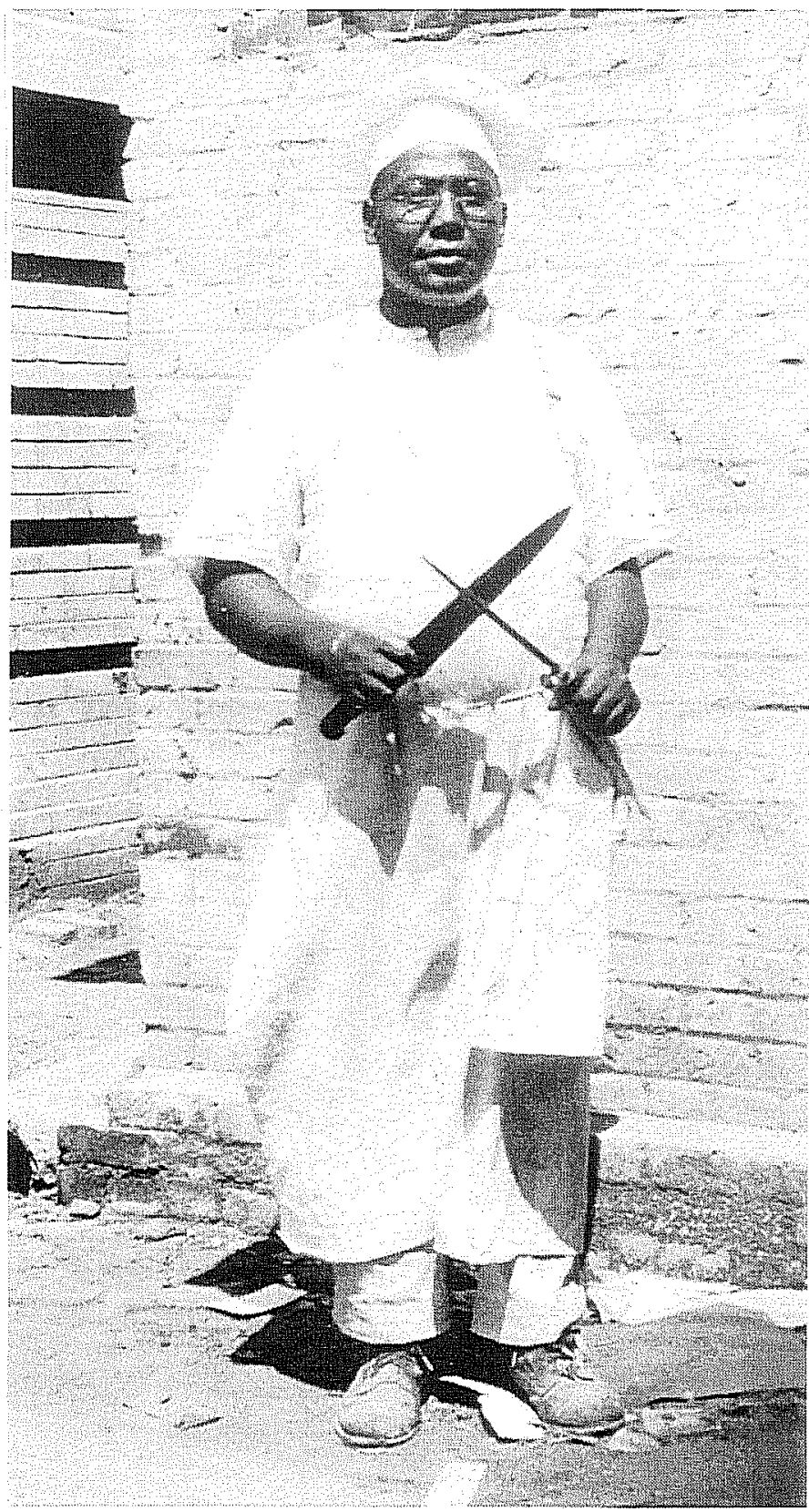

Figure 5-6. Cook for the Riegler Confectionery Store, ca. 1915. ITC collection.

A flourishing grocery enterprise in 1909 located at the corner of Victoria and Indianola streets was owned by P. F. Roberts, a teacher (Figure 5-10). According to Mr. Robert's daughter, Mrs. Henrietta Stevenson (personal communication 1993), he sold meat, coal oil, groceries, and wood. Mr. Roberts opened a second grocery and mercantile store on South Pine Street in 1927. Another success story in the black community was Mr. John Inman, a local civic leader born in 


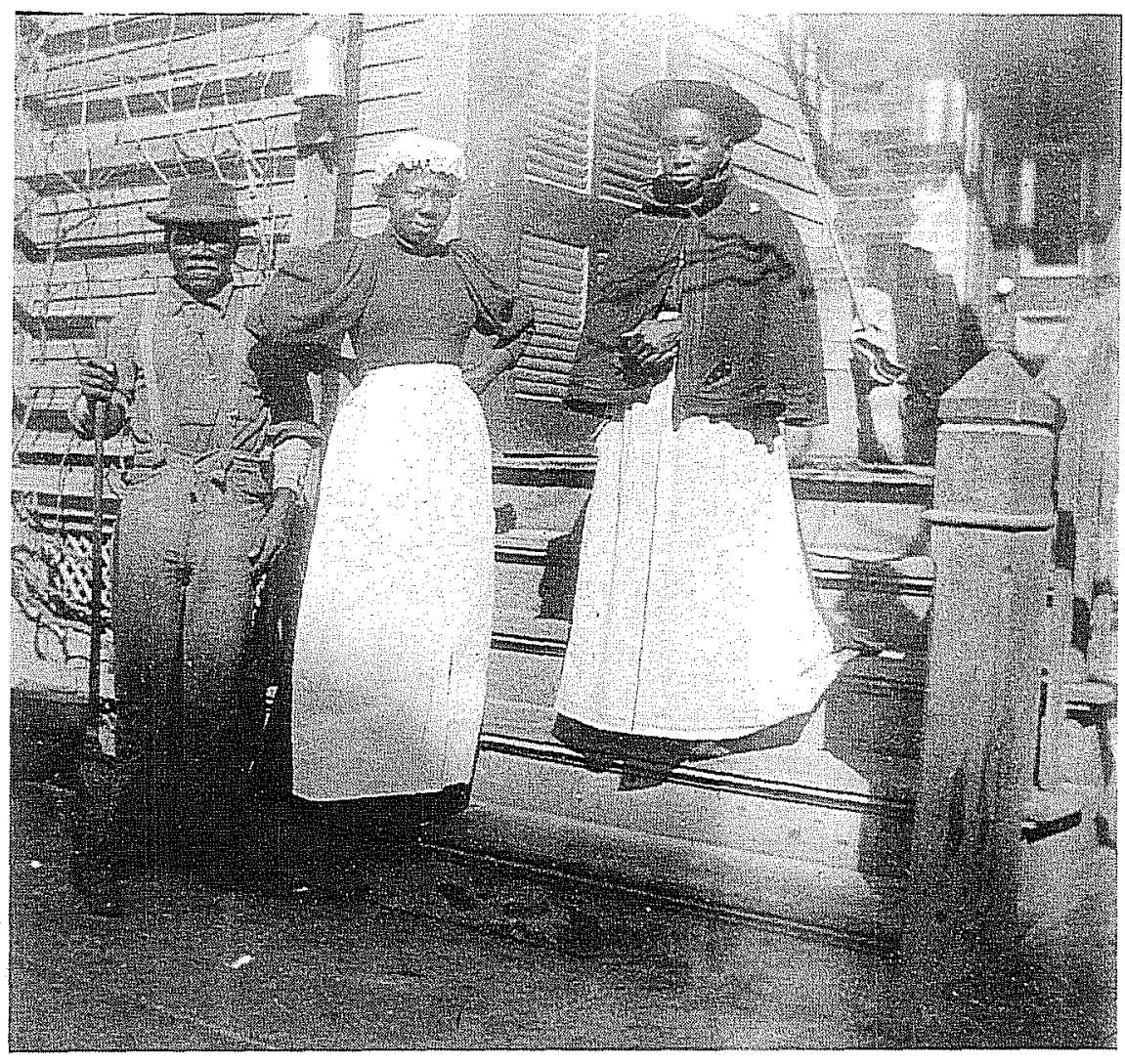

Figure 5-7. Three domestic workers, ca. 1900. ITC collection.

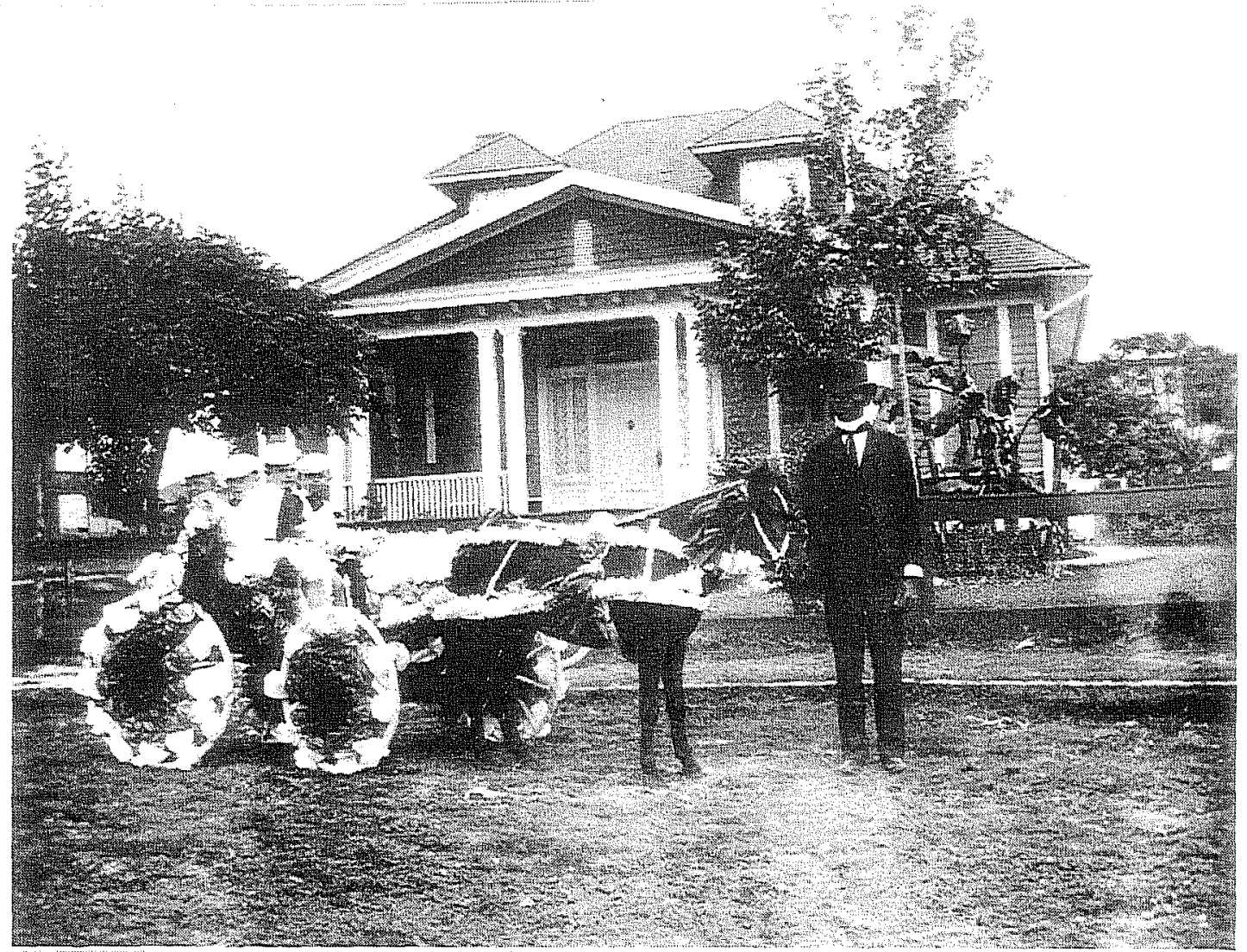

Figure 5-8. Unidentified attendant with boys in cart decorated for the Battle of Flowers parade, April 21, 1904. ITC collection. 


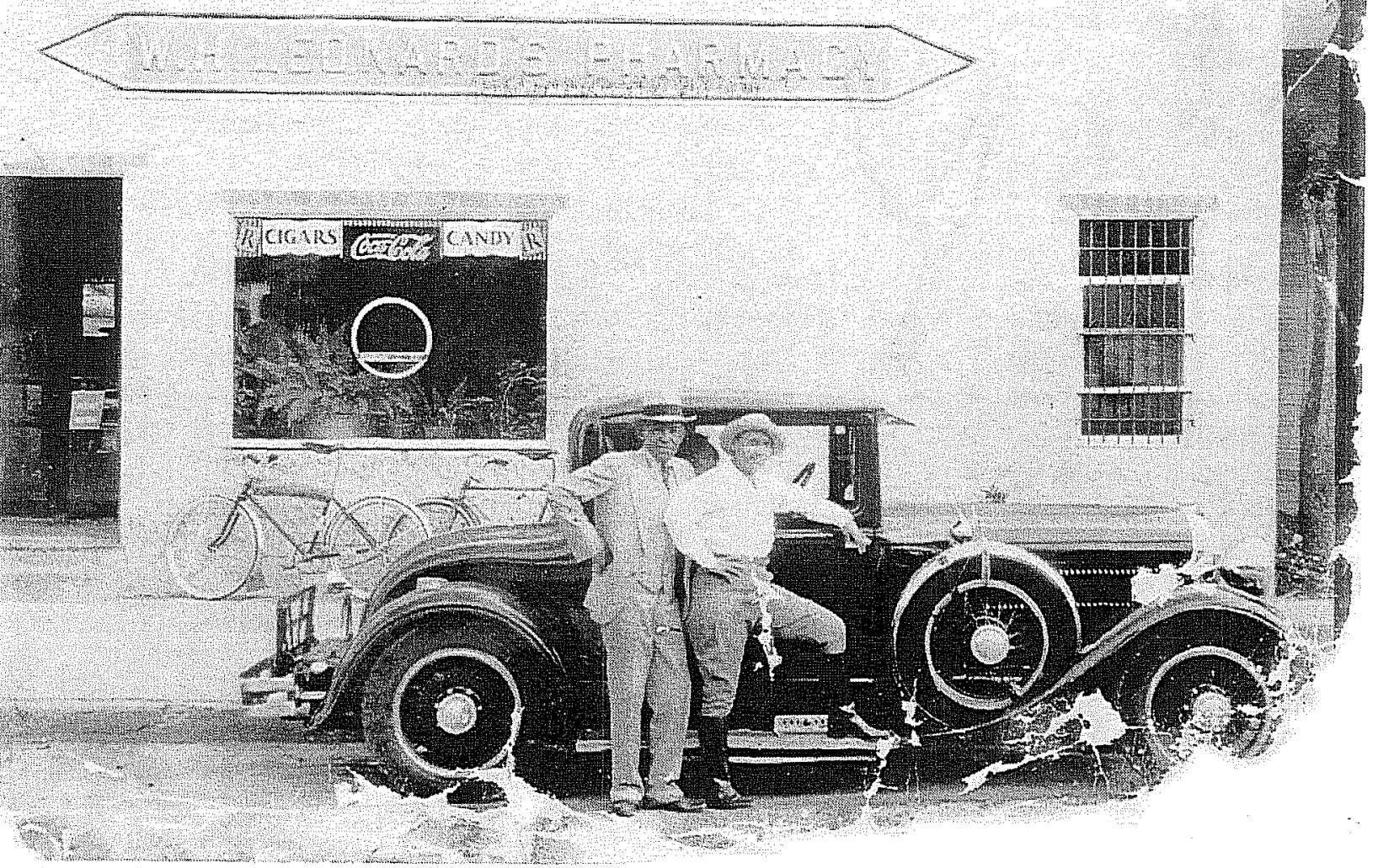

Figure 5-9. Witt Leonard's Pharmacy. ITC collection.

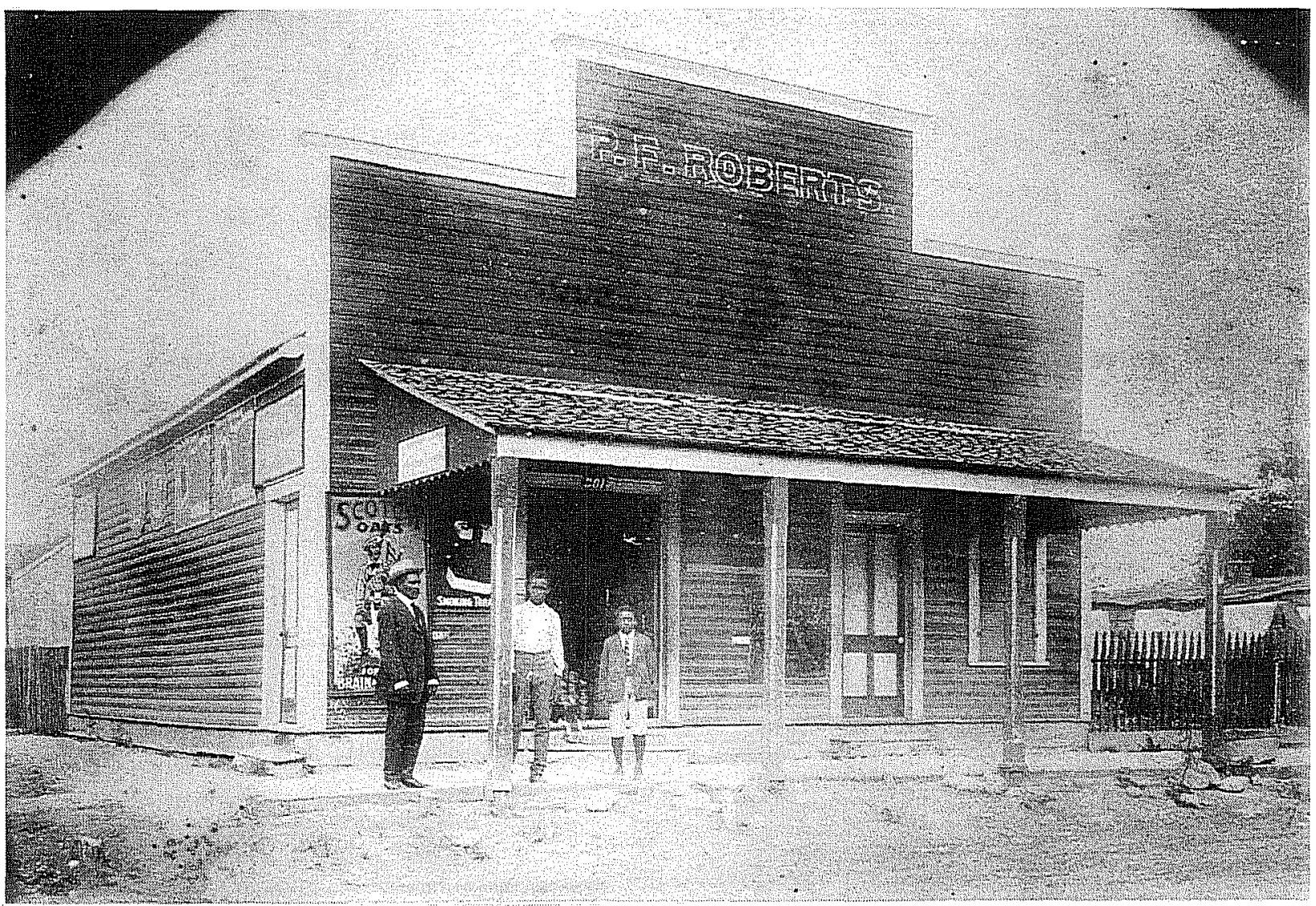

Figure 5-10. P. F. Roberts's grocery, 1910s. ITC collection, courtesy of Henrietta Roberts Stevenson. 
1896, who became not only "the best barber in town" but the owner and operator of three barber shops (Inman, Oral History Interview, 1992). Unlike jobs on the railroad, many of these businesses were unstable and would disappear after one or two years (e.g., Rice 1971:195).

Eating establishments listed by early editions of the San Antonio Register as owned by African-Americans included the People's Cafe, The DeLuxe Cafe, The Do Drop Inn, and The White Swan Cafe on Commerce Street. Bellinger's Cafe was advertised as "An up-to-date Eating House" in the San Antonio Inquirer (SAI, 27 July 1918e:2). Mr. Buddy Edwards ran the Humming Bird Cafe on South Hackberry. Other "eateries" in the area included the Harris Tea Room, the Peacock Inn Cafe and Tea Room, the Kozy Korner Cafe, Effie Taylor's Cafe, and the John Green Cafe, which was one of the most popular black cafes for years (Jones and Runnels, Oral History Interview, 1990). Sylvester Jones and Mr. Runnels (Oral History Interview 1990), old-timers familiar with the area, recall a cafe called the Angle Miner's Inn run by Mr. Enos, located between the Sunset Pawn Shop and the cab stand, going west on Commerce Street. This cafe had a sign advertising it as a "Public Caffe for Colored" in the 500 block of East Commerce Street around 1917. Near the cafe was the taxi and livery company owned by Mr. Bellinger (Figure 5-11). Another cafe, operated by Eddie Carpenter, located "before you get to Crockett and Cherry," was popular with local workers (Jones and Runnels, Oral History Interview, 1990). A popular restaurant with the
Sunday family crowd was the Life Saver Grill run by John Griggs, still standing between Mesquite and Cherry streets on East Commerce (Henrietta Stevenson, personal communication 1993). The Waitz family store on Labor Street, and the Burgess Store on Lockhart and Nolan streets were other stores owned and patronized by African-Americans (Henrietta Stevenson, personal communication 1993). The San Antonio Music Company at 316 West Commerce Street, owned by Isaac Bledsoe, the famous AfricanAmerican singer, offered records for sale such as the "Basement Blues" and the "Pork Chop Blues" in the early 1900s (SAI, 29 November 1924a:4).

One option open to many hard-working AfricanAmericans supporting families was to balance a number of jobs. The Reverend J. C. Glosson describes his father as supplementing his nighttime "stationary" fireman job with the railroad by selling ice from the Lone Star Ice House during the day. The Reverend Glosson's father also sold watermelons at the George Hickey Market located on Commerce Street and Chestnut Street across from Sugarman's Store (Glosson, Oral History Interview, 1992). Claude

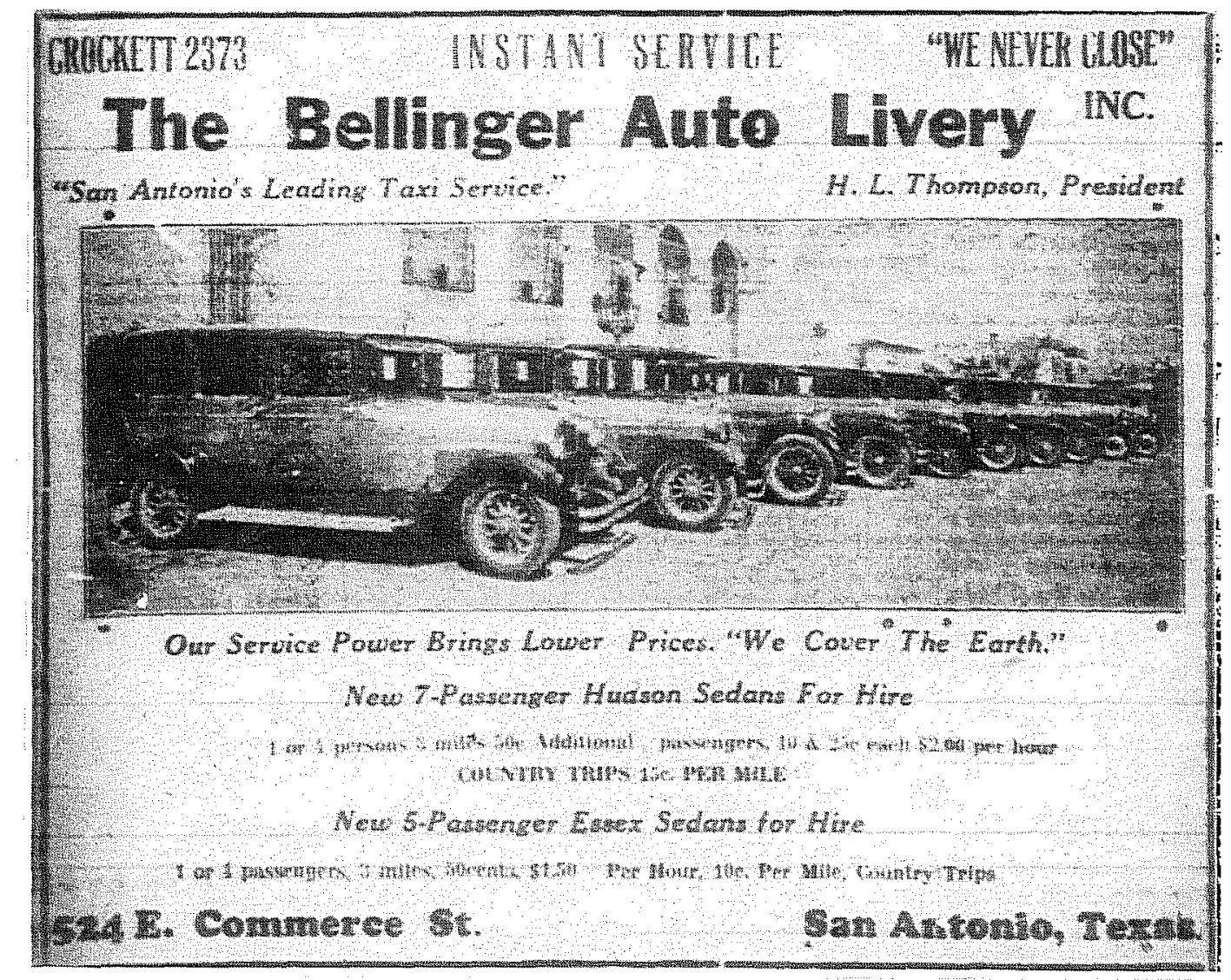

Figure 5-11. Bellinger Auto Livery, 1931. ITC collection. 
Black, Sr., although earning a good living for the times as a Pullman porter, supplemented his income by selling cement. His son, the Reverend Claude Black, notes that during the Depression, blacks in service occupations such as porters suffered because tips were no longer generous. Despite these hard times, the Reverend Black recalls that his father borrowed money for him to attend classes at St. Philip's College (Black, Oral History Interview, 1992).

This hard work ethic was inculcated in AfricanAmerican families through example. The Reverend Black (Oral History Interview 1992) held extra jobs such as delivering ice and working in his aunt's grocery store as a young boy. The Reverend J. C. Glosson recalls riding a streetcar to sell newspapers before Sunday school at the old Mt. Zion First Baptist Church in the early Baptist Settlement (Figure 5-12). Following Sunday school, he and his brothers shined shoes at Fort Sam Houston, where he reports making good money on tips, which paid for their school supplies but mostly for entertainment such as the "picture show." In the summer, the Reverend Glosson earned extra cash by picking cotton in the fields owned by German and Polish-Americans around what is now W. W. White Road. He would also help his father, James Glosson, deliver ice on a horse-drawn wagon (Glosson, Oral History Interview, 1992).

Many prominent African-Americans of the era were involved in funeral and mortuary services. For instance, several editions of the 1918 San Antonio Inquirer (e.g., SAI, 20 July 1918f:12, 29) list prominent advertisements by funeral directors and embalmers such as Williamson and Son Funeral Directors located at 601 Centre Street, and Carter and Sutton Funeral directors located at 220 Chestnut Street, on the first floor of the Beacon Light Hill Lodge, also called Tom Star Lodge Hall (Sutton, Oral History Interview, 1990:7). Many of the funeral parlors in the 1920s provided additional services such as leasing out rooms to various social organizations for

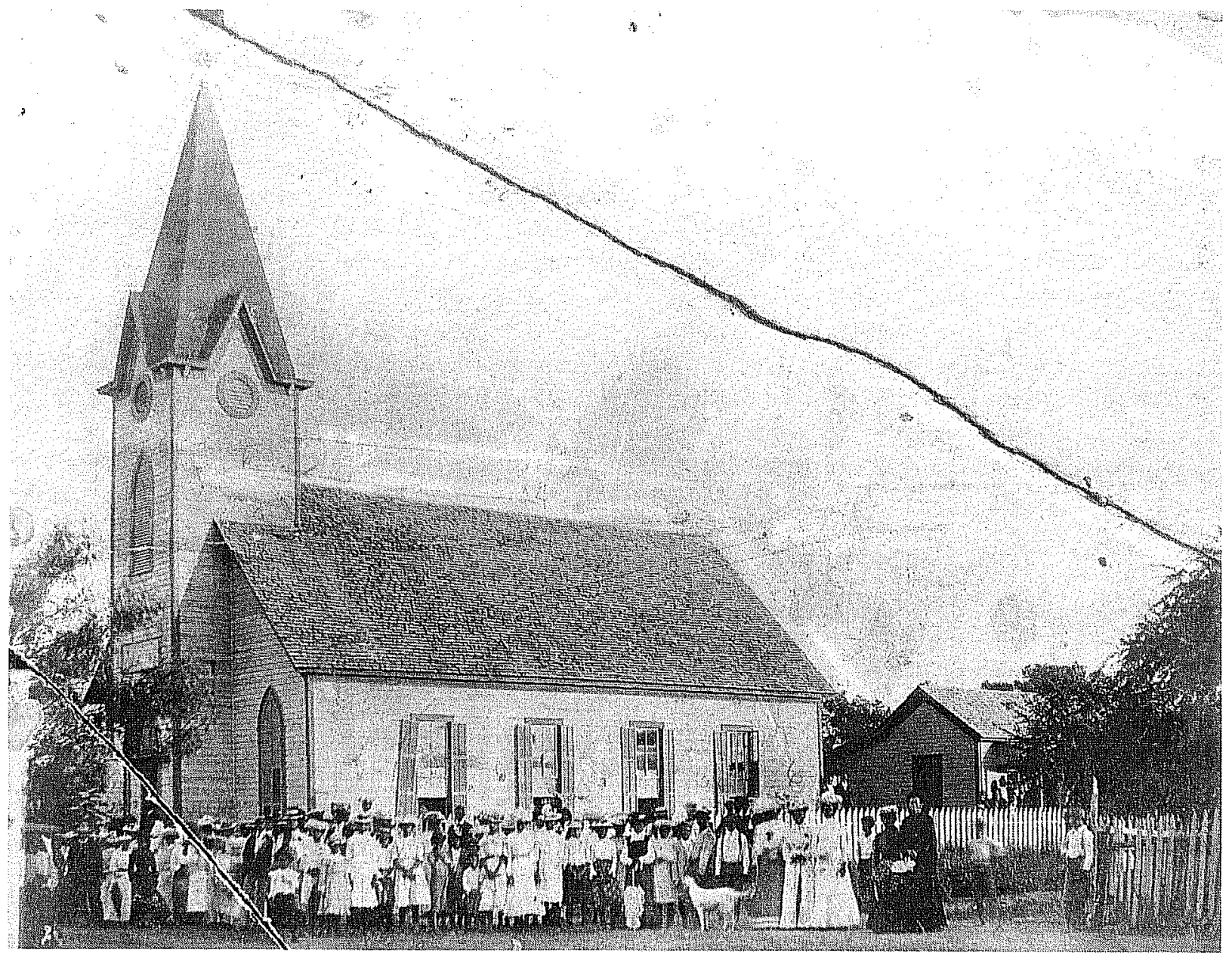

Figure 5-12. Mt. Zion Baptist Church. ITC collection. 
meetings. Frank E. Lewis, who took over the Mt. Zion Funeral Parlor owned by G. W. Bouldin, located at 230 Centre in the 1930s, advertised the installation of new accommodations such as "air conditioning with air circulation" (SARME, 1991:9). The Mt. Zion Funeral Parlor moved to 207 Centre Street at the location of St. Paul's Church and, under the new direction of Frank E. Lewis, placed a large advertisement in an early edition of the San Antonio Inquirer (SAI, 29 November 1924b:19 (34):3) promoting its new limousine and ambulance service as the only real "Ambulance owned by a Race firm" in Bexar County.

One of the most prominent names in the mortuary business was the Sutton family, the business begun by S. J. Sutton, also a recognized leader of education in the black community. His son, G. J. Sutton, continued the family dynasty by expanding Sutton and Sutton Mortuary at 220 Chestnut. The Sutton family enterprises were an economic success in early San Antonio, buying up numerous rent properties and a farm on Sinclair Road where vegetables were raised to feed the large family of 15 children (ITC files, Sutton-Taylor 1977:R.II:15), including a foster son who they raised from age six (ITC files, Sutton-Taylor 1977, R.II:27, 30). Sutton enterprises not only owned a funeral home but a grocery, a shoe store, and a mattress factory; even a skating rink on the corner of Chestnut and Dawson, in the midst of their rent houses. His daughter, Lillian Sutton-Taylor, recalls admonitions from her foster grandmother, Mrs. Handley, to her mother on the perils of dancing at the skating rink. "I can hear her say now to mother, 'Sister, you better come down to the skating rink, the people are slipping in, and in a short while, no doubt, they will be dancing'" (ITC, 1977, R. 1:15).

A prominent name, in particular, stands out in San Antonio during the early twentieth century: the controversial Charles Bellinger (see Figure 5-3). "Charlie" Bellinger and his family moved to San Antonio in the early 1900 s using money he had earned as a dealer in a gambling enterprise. His gambler's luck continued in San Antonio where he won enough money to open several saloons and become one of the city's foremost entrepreneurs and millionaires. $\mathrm{Mr}$. Bellinger owned pawnshops, "counting houses," a cab and livery company, a pool and dance hall, real estate, and the first black theater. He was also the "first undisputed political boss" of San Antonio. Although he had connections to the underworld, Bellinger was a generous benefactor and political boss who, through a clever scheme of organizing a block of black voters, gave African-Americans a voice in decisions made in San Antonio politics (SARME, 1991:3; see also Bailey 1993). In return for his support of the local "political establishment," a park system was established for blacks, black policemen were employed, and a libraryauditorium was established in 1929 (Sapper 1979:68 citing the Negro Labor News, 27 June 1937:2).

The Reverend J. C. Glosson, Jr., recalls as a child seeing Charles Bellinger jogging slowly from New Braunfels Avenue to Houston Street, followed by his black chauffeur-driven limousine. On his way back home, Mr. Bellinger would take the limousine, frequently stopping to give the young J. C. Glosson a ride (personal communication 1993).

Charles Bellinger was known to give expensive gifts such as Cadillacs at social and political functions (J. C. Glosson, personal communication 1993). It is said that even if you wanted to teach school you had to be approved by Mr. Bellinger (Kathy Little, personal communication 1992). Among Texas politicians seeking his approval was a young Lyndon Baines Johnson, later to become president of the United States (SARME, 1991:2). In 1936, following a "tip off" by a competitor, Charles Bellinger was sentenced to 18 months in the federal penitentiary for income tax evasion. However, rumor is that because of connections to President Franklin D. Roosevelt, he was released shortly thereafter (SARME, 1991:3).

\section{The Heart of the Matter}

Many of the patterns of African-American ethnicity relate to the subtleties of everyday life. At the heart of the behavior that is part of "getting by" (e.g., Cheek and Friedlander 1990:55) is the African-American female. More than one-half of all African-American women in the 1930s were in the work force, compared to one-fourth for Mexican-Americans and AngloAmericans (Blackwelder 1984:39). In 1940, the percentage of black females working outside the home was 54.3 percent compared to 15.7 percent for Mexican-Americans, 15.3 percent for native born Anglo-Americans, and 11 percent for foreign-born 
citizens (Blackwelder 1984:206). Clearly a high number of African-American women were engaged in domestic and personal services; in 1930, this percentage rose to a high of 91.3 percent (Blackwelder 1984:229). This fact may account for the low mediansize African-American family (2.63) compared to other ethnic groups in 1930: Mexican-American (4.28); foreign-born Anglo-American (3.19); and native-born Anglo-Americans (3.06) (Blackwelder 1984:208).

African-American women with small children, attempting to augment their incomes, were more likely to take in laundry, mending, or ironing at home (Blackwelder 1984:73) while other women would seek outside domestic jobs as nursemaids or cleaners as soon as their own children were selfsufficient (Glosson, Oral History Interview, 1992). Addie, shown in Figure 5-13 with a child and the family pets, was a cook for the Kenney family in 1909. In many cases, domestic work was the only option available to the female heads of homes. Tillie Brackenridge, a former slave married to Henry Brackenridge, is shown in Figure 5-14 seated on the porch of the Vance residence, where she worked as a housemaid in 1900 . Later she was to live in a little house on Crockett Street (Mock 1995). A maid shown in Figure 5-15 does not appear to be much older than the children she tends.

However, work as a servant in a more affluent AngloAmerican household provided more than supplementary monetary support to AfricanAmerican females: employment by a wealthy patron provided a network of advantages for one's family, including being exposed to "white" standards of success, modes of dress, and social etiquette; access to hand-me-downs; and the opportunity to obtain jobs for one's own family members. The Reverend J. C. Glosson (Oral History Interview 1992) recalls earning extra money by doing odd jobs at the homes where his mother worked. Some of his mother's wealthy patrons also purchased new clothes for him and provided him with money for school supplies. Having relatives employed in white neighborhoods also gave one a license to cross over into these neighborhoods, thus providing more opportunities to supplement incomes.

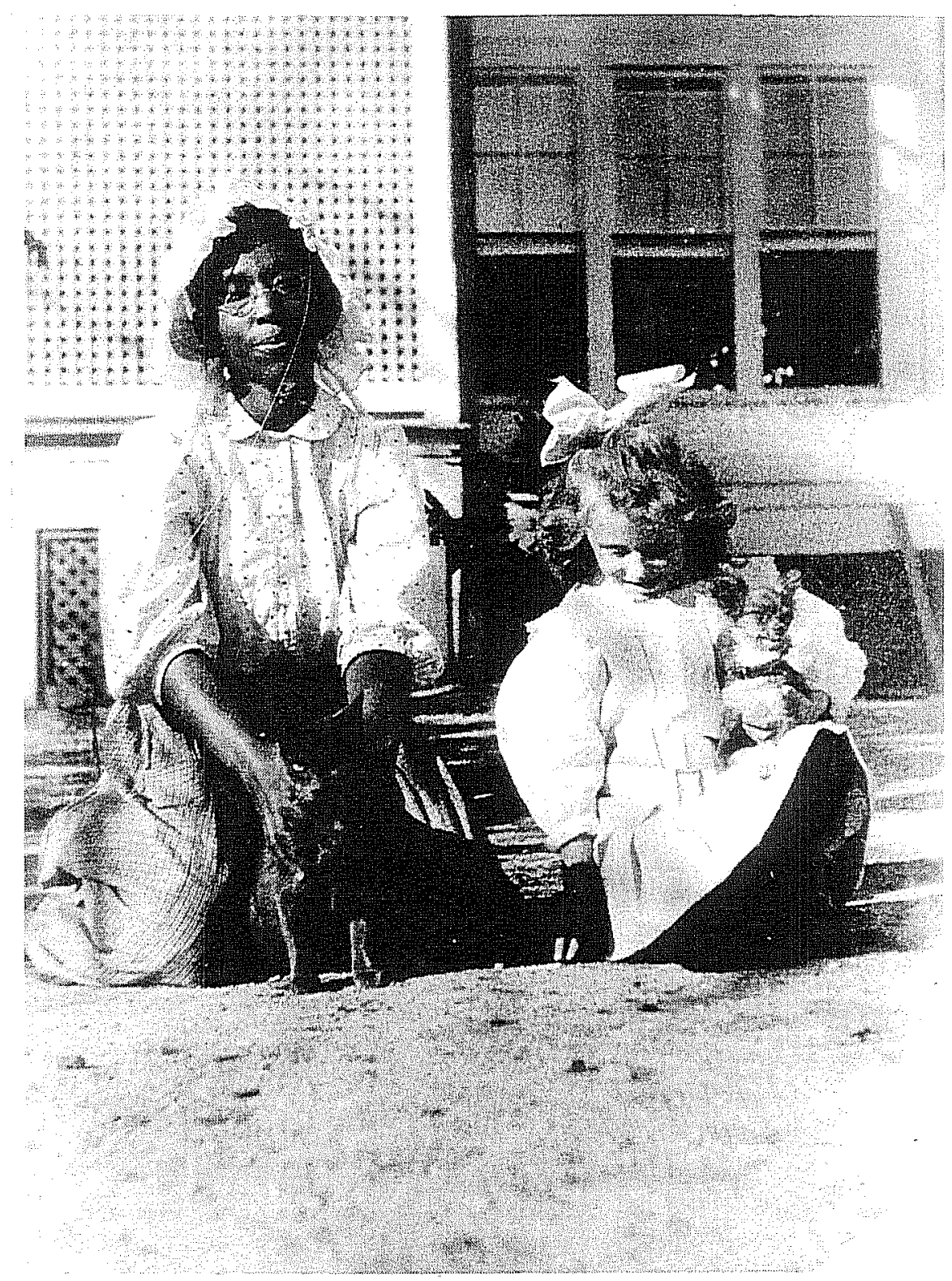

Figure 5-13. Addie, cook for the Dr. John W. Kenney family, ca. 1909. ITC collection 


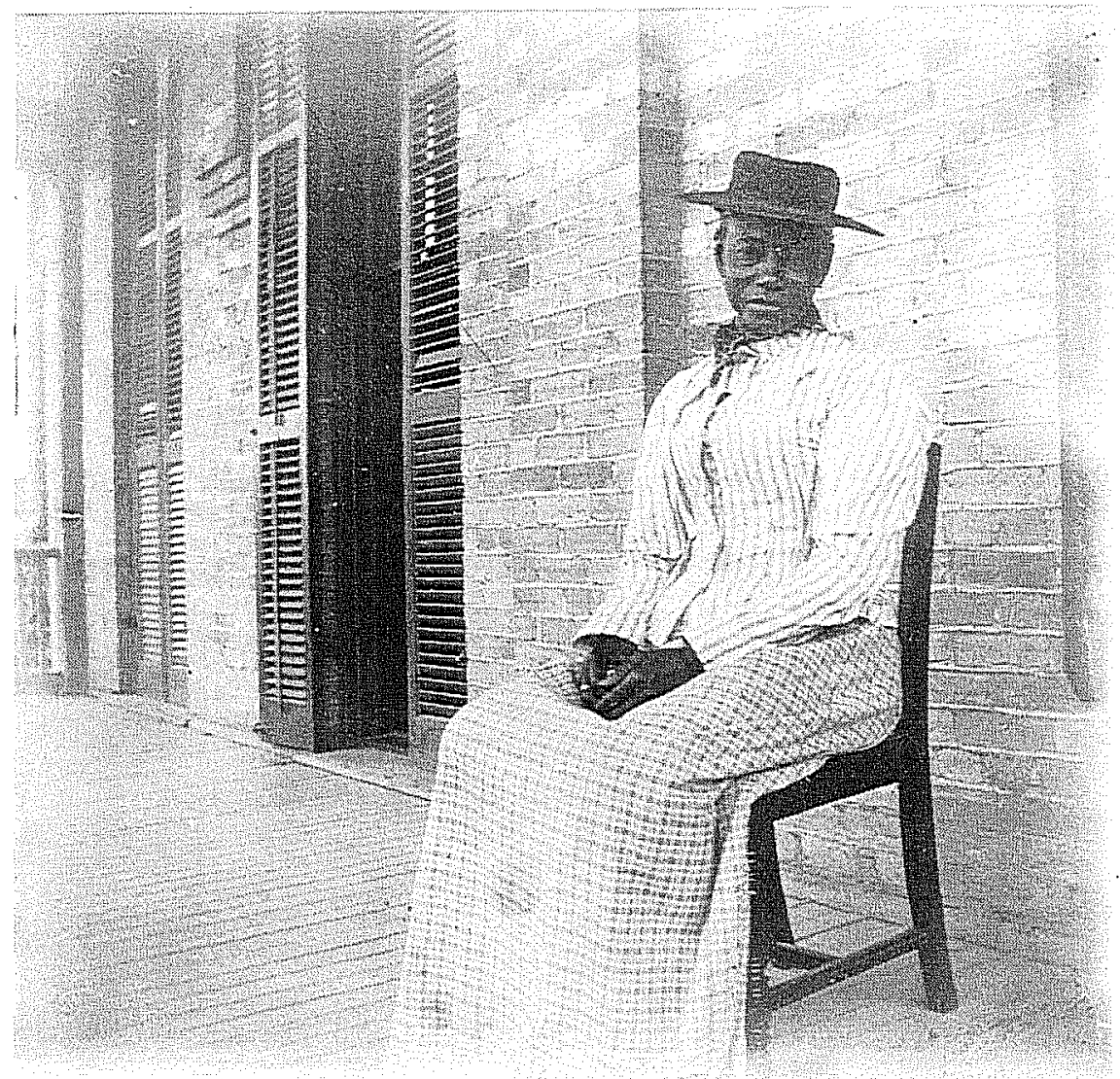

Figure 5-14. Lillie Brackenridge at Vance residence, ca. 1900. ITC collection.

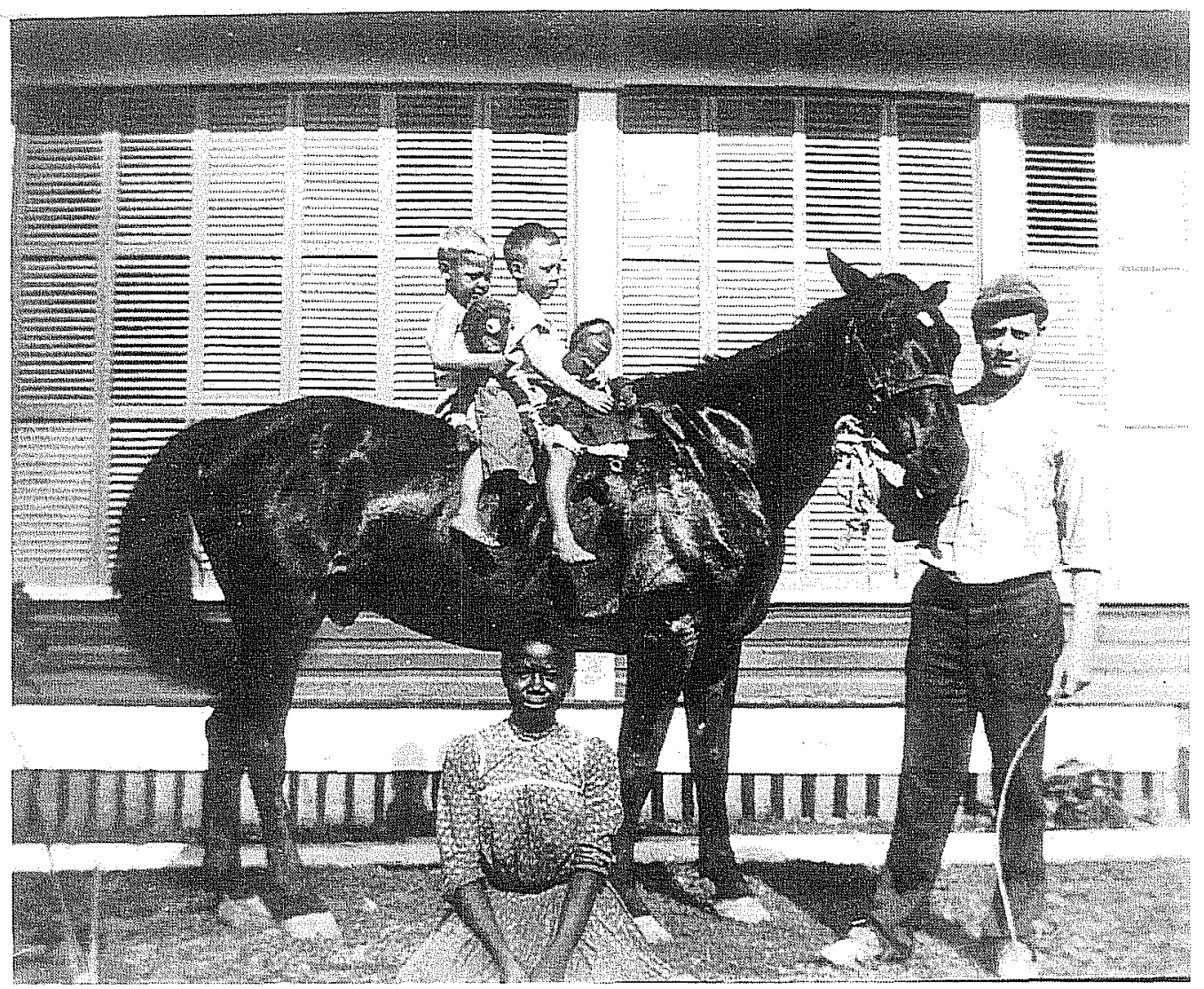


Another avenue other than domestic work open to aspiring black women is suggested by advertisements in early editions of the San Antonio Inquirer. Advertisements of beauty shops selling products such as "miracle acting bleaches," "Black and White bleaching creams," or "French hair coloring" are prominent. While these products appealed to black females trying to cope with dominant white cultural mores of beauty, other businesses peddled elixirs appealing to more universal concerns such as "eternal youth" or "hair restorers." Newspaper advertisements suggest that interest in systems of "hair culture" such as Madame St. Claire's (SAI, 20 July 1918g:2) or "shops of beauty culture" (SAI, 7 November 1925a:1) was high in the African-American community. One of the earliest "beauty product" entrepreneurs was Jesse Mae Hicks, who started Hick's Beauty School on South Pine Street (SARME, 1991:2), and who today is a legend in the black community, known for her business acumen and financial success.

Other success stories include Katharine (Kitty) Beverly, who worked as a social columnist for the San Antonio Register for 37 years. According to her sister, Lucile Foley Mitchell, (personal communication 1993), Katharine also wrote two books of poems, $A$ Distant Spring and Fingers of Time. Katharine began writing poems while in high school, eventually joining the Avalon Poetry Study Group in San Antonio, studying with Aline B. Carter, a Poet Laureate of Texas. Mrs. P. A. Thompson was another successful African-American woman, who worked for the government as an inspector of stores and became a prominent leader in the fraternal lodges (Black, Oral History Interview, 1992; Glosson, Oral History Interview, 1993 ).

Artemisia Bowden, a young teacher arriving in San Antonio in 1902 to serve as chief administrator and primary teacher at St. Philip's private school run by the Episcopal Church, became a prominent force in African-American education. Artemisia Bowden not only initiated new programs, but was an ardent fund raiser, her efforts succeeding in the designation of St. Philip's as an accredited junior college in 1927. In 1954 Mrs. Bowden, after 52 years of academic leadership, was made Dean Emeritus of St. Philip's College (Pat Davila, personal communication 1993).
Newspaper accounts not only attest to the arousal of the political voice of black females through such organizations as the NAACP, with a membership of 600 in 1917 (SAI 10 August 1918h:1), but also to new interest in gender inequities through the announcements of meetings such as the Colored Women's Suffrage and Protective League founded in 1917 in San Antonio. The Women's Progressive Club, the 1929 founding members of which are seen in Figure 5-16, was responsible for charitable work such as raising funds to build the Ella Austin Children's Home for orphans. According to Mrs. S. E. Davis (personal communication 1993), Ella Austin was inspired to start the orphanage after observing two little orphans in church services on Sunday.

Mrs. Urita Fairchild was a leader in promoting education for young black girls in the early San Antonio community. Mrs. Fairchild taught and directed the United Way-sponsored YMCA at Pine and Cross streets, where young girls "learned etiquette and refinement" that would prepare them for college (ITC files, Sutton-Taylor 1977:R.I:9).

\section{"Sisters" and "Brothers"}

Ethnic groups on the lower end of the economic scale tended to supplement income through a variety of specialized activities, especially during the lean depression years of the 1920s. Supplementary activities included the collection, processing, and/or storage of food products; small scale manufacturing or mercantile activities; and the housing of people. This last activity was an important means of bringing in additional income among early African-American families in San Antonio. Documents quantify a marked increase in African-American families taking in boarders between 1880 and 1900 (Truss 1986:21). Blackwelder (1984:210) observes a large percentage of AfricanAmericans with subfamilies and/or lodgers compared to other ethnic groups during the years of the Depression in San Antonio. For example, with one or more lodgers per family, African-Americans compared much higher at 10.6 percent to the 3.4 percent of Mexican-Americans and 6.8 percent of Anglo-American families (Blackwelder 1984:210). Unlike other ethnic groups such as MexicanAmericans, the cultural ethos of African-Americans 


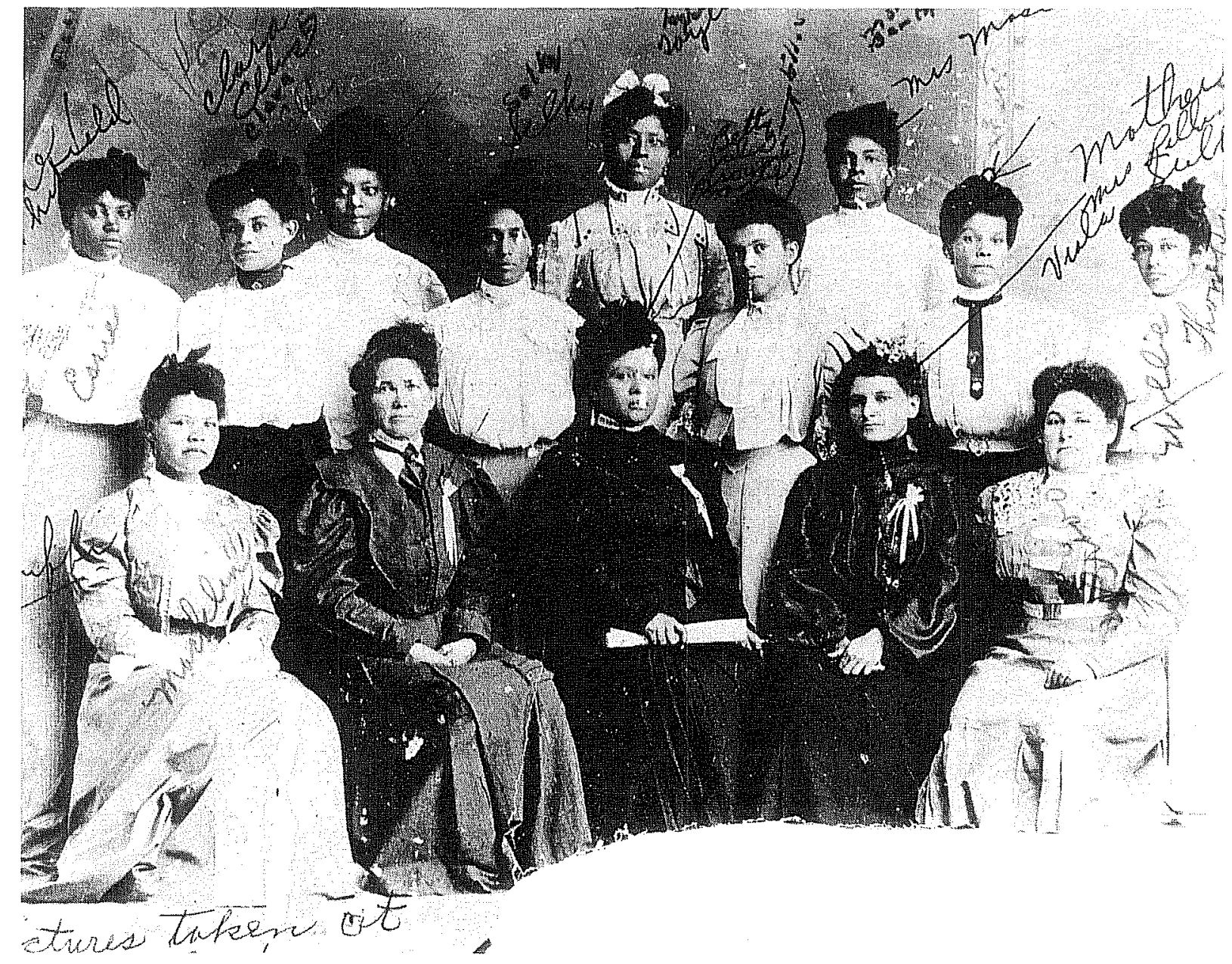

Figure 5-16. Women's Progressive Club, ca. 1929. ITC collection.

supported these economic activities (Blackwelder 1984:34).

The deed and census records of the properties in the study area centered on Runge Street were too limited to support the results of this research. However, the previously mentioned house built at the rear of the property at 130 Nebraska (MLK), was rented out by Sam L. and Emiling Andrews to Eugene Davis, a black Pullman porter (CD 1921-22).

Certainly, economic motivations played a significant role in the taking in of boarders, renters, or rentpaying family members. Taking in boarders, however, was also part of the spirit of reciprocity governing relationships in the African-American community in early San Antonio. African-Americans, in addition to their churches and their benevolent organizations, could count on one thing: their network of kin relationships, both fictional and real (e.g., Stack 1974). Beatrice Clay describes a typical situation when her family went to live with an uncle who was in danger of losing his home due to extended unemployment. Already living in her uncle's home were her grandmother and an orphaned nephew. Rent paid to the uncle by Beatrice's family allowed the uncle to pay the interest on his note and keep his home (Blackwelder 1984:34).

This practice of household "pooling" among friends and kin also occurred in wealthier African-American families. The socially prominent S. J. Sutton had a 
rooming house (ITC Files, Record II, 22). The Suttons also took on the extra responsibility of sending a promising young black student, Myra Hemmings, to Howard University when the Second Baptist Church was no longer able to help (ITC files, Sutton-Taylor, 1977 R.I:21). Mrs. Sutton-Taylor, daughter of S. J. Sutton, recalls living with Mrs. Alexander at 133 Canton Street during the school year, after her family had moved to their farm in the country (ITC files, Sutton-Taylor 1977:R.I:16). The Reverend Claude Black remembers his mother and father, Claude and Cora Black, renting one of the two bedrooms in their small home to Mrs. Rosalind Benson. Mrs. Benson later became the first black woman to play in concerts at the Municipal Auditorium (Black, Oral History Interview, 1993).

It has been argued that adversities faced by blacks following the Civil War nourished a reliance on kin (Bodnar et al. 1982:32). Archival data and oral interviews support the fact that African-American families formed close-knit networks of relationships, a factor easing transitions and forming a buffer with the rest of the Anglo-American community. Farreaching kin networks also provided information about job opportunities to immigrants from tenant farms or other overcrowded urban areas seeking a better way of life.

African-American children in San Antonio were more likely to live in a home other than their own in comparison to other ethnic groups, according to Blackwelder's (1984:33) studies. This practice was undoubtedly due in part to the rudimentary education offered to African-American students in Texas, who were often forced to move to larger cities to have access to higher levels of education. Blackwelder (1984:33) relates the story of Anna Graves, a young black girl who came to live with her aunt in San Antonio in the 1930s because there were no high schools for African-Americans in her home town of Seguin. Mrs. Wilson (ITC files:no date) describes the impressions of a young black girl in moving from a rural elementary school to the high school in San Antonio: "had outdoor basketball court. No indoors like the white children. But we had the outplayenist basketball team you ever seen. Just natural born players."

\section{Voice of the Community}

African-American-owned newspapers have traditionally provided a forum to record the achievements of their patrons and to note blatant racial injustices. Two San Antonio African-American newspapers were born during the early 1900s: the Weekly Hustler (WH), with $\mathrm{H}$. C. Lewis as editor; and the San Antonio Inquirer (SAI), owned and published by $G$. W. Bouldin. An ugly voice of dissension was provided by the $K$-Lamity's Harpoon ( $K L H$ ), a racist newspaper published initially in Austin, Texas, in 1903. Its tradition of racial hatred was taken over by the American Forum (AF) published in San Antonio from 1923-1925. The paper's blatant discrimination towards blacks was insidious; for instance, gloating headlines of one edition support the magnanimous gestures of the Ku Klux Klan as donating $\$ 15.00$ to the black church (and $\$ 100.00$ to the white Trinity Methodist Church) ( $A F, 24$ February 1923:2). The diatribe of hatred was centered on contrasts between the honest, hardworking blacks of Texas who minded their own business and the "lazy, worthless, idle" blacks who were not respectful to "white" people $(A F$, 1 September 1905:2). Admonitions to blacks included "in public places, such as cars etc., don't always try to wedge yourself in among the whites. . . [and] attend strictly to your own business and avoid every white man who attempts to place himself as your social equal" ( $A F, 1$ September 1905:4). By 1923 the newspaper's incendiary and inflammatory dialogue was extended to the Jews and the Catholics of San Antonio ( $A F, 1$ February 1923). What is of historic importance here is this newspaper's perpetuation of the racist propaganda that African-Americans who subscribed to the Anglo-American work ethic and met the subservient etiquette standards and Uncle Tom obsequiousness could be tolerated in separate but equal facilities required by Texas law.

Despite their troubles with finances and subscribers, black newspapers continued to be an important forum for the voice of black America. The San Antonio Register (SAR), published by Valmo Bellinger, the son of Charles Bellinger, replaced both the San Antonio Inquirer and the Weekly Hustler. Started in 1931, in the middle of the Depression, the San Antonio Register soon became the voice of African-American politicians and concerned citizens. 


\section{The Street That Never Slept}

The business area along Commerce Street, where the stables, wagon yard, bars, and hotels were located, was not only the hub of the black business community, but an unofficially integrated area. It soon became a liminal area where various ethnic groups such as African-Americans, Hispanics, and Indians, who were excluded from the Anglo-American areas, could mix without censure (Wade 1983). The patronage of workers at the Southern Pacific Roundhouse (or the Rip Track), travelers, and later military troops stationed in San Antonio during World War I also contributed to the popularity of the area, noted for businesses that stayed open all night. As Mr. A. C. Sutton, a long time resident of San Antonio, recalls, "the railroad station was a gathering point for Blacks that were in that area because you got a chance to see new people coming in. . . . It was an event. The Blacks always rode right after the cab" (Sutton, Oral History Interview, 1990:6).

The Foggy Bottom on Commerce Street, a Chineseowned establishment, began as a segregated club but later catered to a mixed clientele (Inman, Oral History Interview, 1992). Prominent nightclubs in the area owned by African-Americans included the Black Cat Cafe and the Avalon Grill, west of the Cameo Theatre (Inman, Oral History Interview, 1992; Jones and Runnels, Oral History Interview, 1990). White-owned houses of prostitution and their "sportin' women" were part of the underworld scene around Booker Alley between Live Oak and Chestnut streets (Jones and Runnels, Oral History Interview, 1990). The controversial Hady Brisko's Hotel, later destroyed by fire, was located on the corner of Houston and Cherry streets (Jones and Runnels, Oral History Interview, 1990). Although these brothels could not compete with the more opulent west side bawdy houses in the early 1900 s, they were the focus of gambling and other underworld activities.

\section{Agency and Power}

\section{The Church: a Spiritual People}

Although increasing urbanization and residential segregation in San Antonio contributed to growing social division and prejudice, these forces unwittingly gave added impetus to racial solidarity and motivated blacks to become self-sufficient not only in economic matters, but in all realms of their lives (Rice 1971:265). The black church has traditionally been a prominent source and focus of black empowerment, a "cultural foothold for survival" (Wade 1983:13), providing strategies to deal with poverty and boundaries imposed by the dominant Anglo-American class. The church also served as a weapon for many unemployed blacks in fighting the Depression (Blackwelder 1984:112). "The church was the first community or public organization that the black Texan actually owned and completely controlled" (Sapper 1979:517).

The African-American church has also been a symbol of group identity and shared goals, a source of formal and informal socialization, and a means of inculcating values. As Dorothy Pickett observes, it was "THE place of expression, of mutual communication, of kinship" (Pickett 1971:7; emphasis in original). Early African-American churches included the Mt. Zion First Baptist Church (Figure 5-13); the New Light Baptist Church; and the Free Missionary Baptist in the Baptist Community, located west of the railroad tracks. In the 1940s the churches were forced to relocate further east of the railroad tracks to Denver Heights, after the primarily black Baptist Community was destroyed to make way for a housing project. Other early African-American churches included St. Paul's United Methodist Church on Centre Street and the Second Baptist Church which grew out of the Macedonia Baptist Church (Smedler 1994). Since they did not have baptisteries, church-goers often used the San Antonio River for baptismal services, with exceptions of certain parts of the river that were segregated. Colonel George Brackenridge, a wellknown Anglo-American philanthropist, donated his lands, including part of the river, to the city of San Antonio for a park. However, Colonel Brackenridge declared that the park-subsequently named in his honor-and river would be open to all citizens regardless of race (Inman, Oral History Interview, 1992). In Figure 5-17, the Reverend L. H. Kelley of the Second Baptist Church, located at the corner of Chestnut and Centre streets, is shown baptizing a group of believers on the San Antonio River near Hot Wells in 1914. Other baptisms took place at San Pedro Creek or Salado Creek (Inman, Oral History Interview, 1992) near Pecan Valley. 


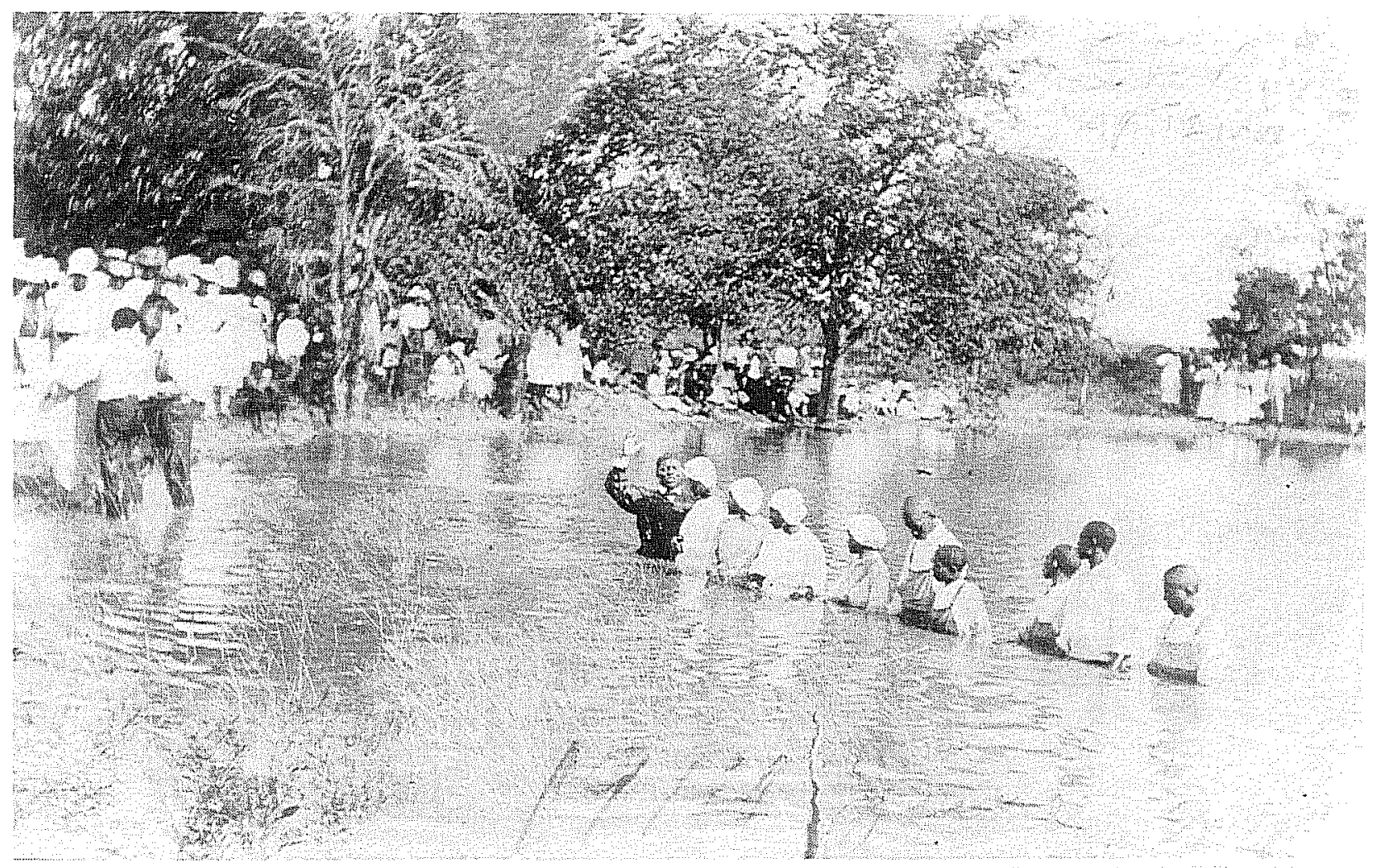

Figure 5-17. Preacher baptizing group in San Antonio River, 1914. ITC collection.

Mrs. Wilson (ITC files:no date) describes such an event on the river banks as a grand celebration:

The deacon would take the big old long whatever he had and measure the water and him and the minister would go out there and they took the one to be baptized and they run you under that water and up. This was the old time way of baptizing, rejoicing in the Lord. The older people from granny on up. It is still in us yet.

The prevalent mythologies and oral histories performed in the expressive rituals of AfricanAmerican churches embodied models for contradictions between the competing systems of power in the Anglo-American and African-American communities. Powerful African-American leaders were also generated and nurtured by the church, independent of the Anglo-American community (Sapper 1979:183). Black preachers were important sources of support to working-class blacks, helping them find jobs and providing other support in the network of reciprocal relationships structuring the African-American community in the early twentieth century (Baer and Singer 1992). The churches also were an empowering agency for African-American females during this time, providing them the opportunity to show leadership skills in the many educational and social activities centered in the church. It has been argued that the African-American religion is a syncretism of African and Christian religions with its own style, outlook, and character (Baer and Singer 1992). One of its salient characteristics is the "dynamic tension" (Baer and Singer 1992:236) of innovation and conservatism in response to traditional American values and external changes. Above all, despite its traditional connections to American Christian evangelical groups, it is not a facsimile of any one group. Socio-religious transformation within the African-American religion is a constant process, as the Reverend Claude Black of the Mt. Zion First Baptist Church pointed out to me (Black, Oral History Interview, 1992). His conceptualization of a religious institution as an active process is important in understanding its place in the dynamics of the early African-American community.

In many ways the African-American church is a paradox. Unlike some white religious institutions, the 
black church confronts social change and social reality (Wilmore 1983:xiii). While the church was and is an active proponent of the working class and espousal of middle-class values, it has also been on the "cutting edge" of social change in the African-American community (Baer and Singer 1992). This holds true today in the Mt. Zion First Baptist Church, which must balance a growing lower middle-class MexicanAmerican constituency with African-American traditions and goals (Black, Oral History Interview, 1992).

\section{The Lodges and Fellowship}

Black fraternal organizations existed in a close relationship with churches, similarly contributing to the development of a strong self identity in the socialization process and providing a format for commonly shared values and goals. Like the churches, the lodges were a syncretism of middle-class white Masonic lodges and African-American traditions. The structure of these typically middle-class social organizations was replicated but at the same time transformed by African-Americans to address their own social and economic needs in an increasingly discriminatory, urban society; participation increasing as segregation became more pronounced (Rice 1971:268).

Certainly, the participation in fraternal lodges was partly economic because, as noted previously, the development of an African-American business class was thwarted by the lack of capital for investments. African-American associations such as the Loyal Friends of America, The Beacon Hill Light Lodge on Chestnut Street, and the Grand Lodge of the Knights of Pythias attempted to fill some of the gaps by providing money as well as burial protection and insurance to middle-class African-Americans (Sapper 1979:511). These fraternal groups also provided loci for church and civic groups to meet (Barr 1973:167). For example, Mrs. Lillian Sutton-Taylor (ITC 1977, Int. 6: Record II) recalls that the Second Baptist Church worshiped in the Odd Fellow's Hall at the corner of Center and Cherry streets until the formal church was completed.

The Odd Fellows of the Household of Ruth, located on Centre Street, were more socially inclined than the
Masonic groups (Rice 1971:269), initiating recreational activities such as parades, balls, and picnics for members known as "Odd Fellows" and "Ruthites" (SAI 7 November 1925b:7). Additional benefits to members included coverage for funeral expenses. A 1925 edition of the San Antonio Inquirer, in an appeal to African-Americans, proclaims that "You need this protection for yourself and your family" (SAI, 7 November 1925c:7). Lodges such as the Grand Union of Colored Laborers were active in working against discrimination in jobs and for improved working conditions (Inman, Oral History Interview, 1992) while the Loyal Friends of America provided insurance to members. However, despite the efforts of lodge leaders to encourage black entrepreneurship, censuses indicate that the majority of property in the predominantly black Denver Heights section of San Antonio was still in the hands of the Anglo-American population as the century neared the halfway mark. The majority of blacks on the lower end of the socioeconomic scale simply did not have access to the capital to invest in land.

In addition to the Masonic lodges, other local and state clubs modeled on Anglo-American organizations were formed, often providing similar benevolent assistance and a setting for social activities. Society pages of 1936 editions of the San Antonio Register report meetings for such social clubs as the Young Men's Improvement Club, the Primrose Social Club, the Girl's Jovial, Sophisticated Knights, and the Gloom Chaser's Social Club, which may have served as a club for young males unlucky in love. Although the clubs may appear to be frivolous, they served as important gender, age group, and status identifiers for many African-Americans in the community. These clubs were supplemented by organizations such as the Campfire Girls, and innumerable school athletic teams which received the wide support of the adult community.

One early citizen of Denver Heights notes that many of the early social clubs were founded by Pullman porters and waiters because, "they'd been working around the rich white folks, and they knew how things were supposed to be done" (SARME 1991:5). A Blue-Vein Society was even organized by those AfricanAmericans who claimed descent from Anglo-American ancestors (Glosson, Oral History Interview, 1992). One of the men's social organizations founded in 1915 , 
the Van Courtlandt Club, is still involved in introducing young African-American women to society and providing money for scholarships.

\section{Conclusion}

This study has sought to provide a glimpse into the growth and development of the African-American community of Denver Heights in San Antonio from 1900-1940. I have attempted to examine the life strategies that these early African-Americans employed in response to racism, urbanism, and economic depression. This analysis of their history and adaptation has depended on data generated from the integration of several sources: the archaeological record, historical documentation, and the present day recollections of African-Americans themselves.

Ethnic groups, such as black Americans on whom social and economic boundaries are imposed, are not passive but attempt to develop a series of adaptive strategies. Such activities might include the incorporation and/or transformation of the symbols of the dominant society or a reorganization of their own unique cultural institutions or values (e.g., Staiano 1980). In such a world, for example, distinctive aspects of material culture forms or their disposition might communicate black ethnicity. Although such processes can be observed in the archaeological record of some ethnic groups, they become more difficult to extricate in an urban setting such as early twentieth- century San Antonio. Indeed no qualitative or quantitative differences could be discerned in the archaeological evidence from this time period to suggest distinct ethnic behavior. Admittedly, the investigation of such behavior was compromised by the lack of adequate diachronic data and the interdigation of ethnic groups in the study area. Also, potentially ethnically sensitive evidence such as architecture or landscape was compromised by the removal of most of the structures prior to Phase IV of the Alamodome Project in the NCB 636 area.

Part of the invisibility of ethnicity in some material class assemblages is undoubtedly due to the conflation of socioeconomic and ethnic variables. Accordingly, African-American behavior correlates might be mirrored in the material culture of other struggling groups during the early twentieth century in San Antonio; groups which also had unequal access to resources and held unskilled jobs.
A more subtle form of empowering ethnicity has been the focus of this report on the history of the AfricanAmerican community in San Antonio, ca. 1900-1940. The effects of discrimination in "separate but equal facilities" and the imposed segregation in residential locus in early twentieth-century San Antonio led to a collective ethos of "mutual aid" and a widening network of supporting institutions and sustaining bonds of reciprocity in the African-American community. Many of the institutions of "solidarity," such as churches and lodges, were appropriated from the dominant Anglo-American culture, but reorganized by African-Americans into their own unique communication system and mode of survival. The family unit was extended to an ever-widening network of reciprocal relationships in this period of mutual aid. This encompassment is at once conservative and innovative, a two-way process in which "new institutions make participants, not recipients out of excluded people" (Simpson 1978:245). As one black writer cogently remarked about his fellow blacks in the San Antonio Register, the voice of the black community, "whenever he took the white man's substance he practically renovated it; in that he took a new style and a new interpretation" (SAR 1932:2). However, this dialectical relationship between the forces impelling a society to change and those seeking to preserve the past (Rice 1971:XI) has created a dilemma for many present day African-Americans.

\section{Acknowledgments}

I would like to acknowledge the individuals who gave their time to submit to share their thoughts and answer my probing questions: Mrs. Evelyn V. Anderson, the Reverend Claude Black, Mrs. Patsy Campbell, Clyde Glosson, Edgar Glossen, the Reverend J. C. Glosson, John Inman, Lucile Foley Mitchell, Mrs. Dorothy Pickett, Oscar Powell, Mrs. Henrietta Stevenson, and Mrs. Augusta Whitten. Thanks are also due to Mrs. Janet Baity, Mr. George Clark, Jr., Mrs. S. E. Davis, Mrs. Norris McVea, Kathy Little, for information provided to me in this stage of research. I also gratefully acknowledge the input of Herbert J. Bailey and Eddie Harris at St. Philip's College. Later interviews in 1995 with Tom Hall, Sylvester Jones, A. J. Sutton, and Dr. Prenza Woods for a second research paper clarified or supplemented this information. 


\section{References Cited}

American Forum

1923 [Ku Klux Klan article] 24 February:2.

Baer, H. A., and M. Singer

1992 African-American Religion in the Twentieth Century: Varieties of Protest and Accommodation. The University of Tennessee Press, Knoxville.

Barr, A.

1973 Black Texas: A History of Negroes in Texas 1528. Pemberton Press, Austin.

Barth, F.

1970 Ethnic Groups and Boundaries: The Social Organization of Culture Difference. George Allen \& Unwin, London.

Blackwelder, J. K.

1984 Women of the Depression: Caste and Culture in San Antonio, 1929-1939. Texas A\&M University Press, College Station.

Blackwell, J. E.

1975 The Black Community: Diversity and Unity. Dodd, Mead, and Company, New York.

Blauner, $\mathbf{R}$.

1970 Black Culture: Myth or Reality. Afro-American Anthropology, edited by N. E. Whitten and J. Szwed, pp. 347-366. Free Press, New York.

Bodnar J., R. Simon, and M. P. Weber

1982 Lives of Their Own: Blacks, Italians, and Poles in Pittsburgh, 1900-1960. University of Illinois Press, Urbana.

Brewer, J. M.

1947 More Truth than Poetry. Austin, n. p.

Cheek C. D., and A. Friedlander

1990 Pottery and Pig's Feet: Space, Ethnicity, and Neighborhood in Washington, D.C., 1880-1940. Historical Archaeology 24(1):34-60.

Davis, J. L.

1978 San Antonio: A Historical Portrait. Encino, Austin.

Deetz, J.

1960 Invitation to Archaeology. Natural History Press, Garden City, New York.

Evans, W. S., Jr.

1980 Food and Fantasy: Material Culture of the Chinese in California and the West, ca. 1859-1900. In Archaeological Perspectives on Ethnicity in America, edited by R. L. Schuyler, pp. 89-96. Baywood, Farmingdale, New York. 
Glazer, N., and D. P. Moynihan

1970 Beyond the Melting Pot. Harvard University Press, Cambridge.

Gottfried, H., and J. Jennings

1985 American Vernacular Design: An Illustrated Glossary. Van Nostrand Reinhold, New York.

Hodder, I.

1979 Economic and Social Stress and Material Culture Patterning. American Antiquity 44:446-454.

Johnson, C. S.

1932 Negro Housing: Report of the Committee on Negro Housing, edited by J. M. Gries and J. Ford. Negro Universities Press, New York.

Kirven, L. L.

1974 A Century of Warfare: Black Texans. Ph.D. Dissertation, Department of History, Indiana University, Bloomington.

Lancaster, C.

1986 The American Bungalow. In Readings in American Vernacular Architecture, edited by Dell Upton and John Michael Vlach, pp. 79-106. University of Georgia Press, Athens.

Lofland, L. H.

1973 A World of Strangers: Order and Action in Urban Public Space. Basic Books, New York.

McGuire, R. H.

1982 The Study of Ethnicity in Historical Archaeology. Journal of Anthropological Archaeology 1:159-179.

Mock, S. B.

1995 An Early African-American Community in San Antonio: Visions of the Good Life. Manuscript on file, Beaty Saunders Architects, San Antonio.

Negro Labor News (NLN)

1937 [Citation by author on Bellinger] 27 June:2.

Ortner, $\mathrm{S}$.

1984 Theory in Anthropology since the Sixties. Comparative Studies in Society and History 26(1):126-165.

Pickett, D.

1971 The Early Years. In The Mount Zion First Baptist Church: 1871-1971, San Antonio, Texas. Mount Zion Baptist Church, San Antonio.

Rice, L. D.

1971 The Negro in Texas 1874-1900. Louisiana Southern University, Baton Rouge.

Roosens, E. E.

1989 Creating Ethnicity: The Process of Ethnogenesis. Sage Publications, Newbury Park, California.

San Antonio Express News (SAEN)

1912 [SPS explosion] 18 March.

1916 [Denver Heights] 5 January:14. 
The San Antonio Inquirer (SAI)

1918a [lynching of blacks] 10 August, Volume 12 (32): 1.

1918b [San Antonio offers award] 10 August, Volume 12(32):1 .

1918c [war, minstrel, entertaining troops, hair culture] 20 July, Volume 12,(29):1.

1918d [nurses] 27 July, Volume 12(20):1.

1918e [Bellinger's restaurant] 27 July, Volume 12(20):2.

1918f [funeral parlor] 20 July, Volume 12,(29):2.

$1918 \mathrm{~g}$ [hair culture] 20 July, Volume 12,(29):2.

1918h [N.A.A.C.P.] 10 August, Volume 12(32):1.

1924a [Bledsoe advertisement] 29 November, Volume 19(34):4.

1924b [Mt. Zion funeral parlor] 27 November, Volume 19(34):3.

1925a [hair culture, M. James] 7 November, Volume 20(34):2.

1925b [Odd Fellow's Lodge] 7 November,20(34):7.

1925c [Loyal Friends of America] 7 November 1925, Volume 20(34):3.

San Antonio Register (SAR)

1931 [Cab Calloway, dance] 5 May 1:7.

1932 [The Negro in Art and Literature] 16 May 21(2).

1936a [New Orleans Rhythm Boys] 24 January:1.

1936b [Leon Theatre] April 17 1936, Volume 5(51).

1936c [notice of play] April 10, Volume 5 (49):6.

1936d [reviewer's comment] April 17, Volume 5 (51).

Sapper, N. G.

1972 A Survey of the History of the Black People of Texas, 1930-1954. Ph.D. dissertation on file at Texas Tech University, Lubbock.

1979 A Survey of the History of the Black People of Texas, 1930-1954. Ph.D. dissertation, Texas Tech University, Lubbock. University Microfilms, Ann Arbor.

Schuyler, R. L. (editor)

1980 Archaeological Perspectives on Ethnicity in America: Afro-American and Asian American Culture History, vii. Baywood Publishing, Westport, Connecticut.

Simpson, G. E.

1978 Black Religions in the New World. Columbia University Press, New York.

Smedler, G.

1994 A History of Second Baptist Church: Our Roots. Paper on file at Second Baptist Church, San Antonio.

Stack, C. B.

1974 All Our Kin: Strategies for Survival in a Black Community. Harper and Row, New York.

Staiano, K. V.

1980 Ethnicity as Process: The Creation of an Afro-American Identity. Ethnicity 7:27-33.

Truss, $\mathrm{M}$.

1986 The Black Community of San Antonio, Texas: 1880 \& 1900. Manuscript on file, History Department, The University of Texas at San Antonio. 
Vlach, J. M.

1986 The Shotgun House: An African Architectural Legacy. In Common Places: Readings in American Vernacular Architecture, edited by D. Upton and J. M. Vlach, pp. 58-78. University of Georgia Press, Athens.

Wade, J. C.

1983 An Analysis of Power as Symbolized Within the Historical Black Church in Four Contemporary Black Churches in San Antonio, Texas. Master's thesis, Department of Anthropology, The University of Texas at Austin.

Wiessner, $\mathbf{P}$.

1983 Style and Social Information in Kalahari San Projectile Points. American Antiquity 49(2):253-76.

Wilmore, G. S.

1983 Black Religion and Black Radicalism: An Interpretation of the Religious History of Afro-American People. Orbis Books, Maryknoll, New York.

Wobst, $\mathrm{M}$.

1977 Stylistic Behavior and Information Exchange. In Papers for the Director: Research Essays in Honor of James B. Griffin, edited by C. E. Cleland, pp. 317-342. Anthropological Papers 61, Museum of Anthropology, University of Michigan. 


\title{
Chapter 6
}

\section{Urban Structural Evolution at the Alamodome Development Site: 1850-1950}

\author{
Herbert G. Uecker
}

\section{Introduction}

The Alamodome Project area encompasses approximately 65 acres of land located in the southeastern portion of the central business district of San Antonio. It is bounded on the north by East Commerce Street, on the south by Durango Boulevard, on the east by South Cherry Street, and on the west by IH-37. The extreme northwestern portion of the area was inside of the Mission San Antonio de Valero ejidos (lands) during the eighteenth century Spanish Colonial period. A section of the Acequia Madre or Alamo Ditch ran through the area near the intersection of what later became Lafitte and Santa Clara streets. Lands adjacent to the ditch were used for agricultural production by the early Spaniards. Also, ca. 1874, a shallow, narrow irrigation and storm drainage canal, the Valley Ditch, was constructed. It ran south down the west side of Walnut Street from the Alamo Ditch. Prior to construction of the Valley Ditch and before the early 1850s when the city of San Antonio platted the land into blocks for development, the area was an untamed natural zone just east of town.

The temporal scope of the study is the period from roughly 1850 to 1950 . This is the time frame which encompassed the final demise of Spanish/Mexican domination and the gradual rise of Anglo/Germanic control of the local economy and sociopolitical structure. It is also the time during which the first wave of the Industrial Revolution of western Europe and the Eastern United States arrived in Texas. The histories of Texas and San Antonio during this period, as well as the details of structural development at the Alamodome site, generally reflect the impact of the late-nineteenth/early twentieth-century wave of technological innovation. Thus, one goal of the project was to learn more about the impact of new technologies on the material aspects of cultures and on the social, political, and economic structures which existed in the study area during the period in question.

This chapter concerns the development of the area's physical infrastructure over time. The archival information obtained was used during the archaeological fieldwork in several ways. For example, copies of maps from the period were used in conjunction with existing physical references, such as relatively unaltered streets, to plot the locations of subterranean foundation remnants for historically significant structures. Maps produced during the early part of the time frame, especially those produced for fire insurance purposes by the Sanborn Map and Publishing Company, Ltd., of New York, were most helpful in that regard. Also, cross matches of family or business histories with ownerships or occupancies were used to predict the qualities and quantities of artifacts that a given site would probably yield, thus enabling archaeologists to choose the excavation locations most likely to expedite the performance of their tasks. The efficiency of doing thorough archival research prior to going into the ground has been demonstrated during many previous Center for Archaeological Research (CAR) projects. The Alamodome project reaffirmed the importance of such research. 


\section{Organization and Research Methodology}

The historical sequence of development of residential, municipal, commercial, and industrial structures within the Alamodome construction area is presented in subsections on new city blocks (NCBs). The block summaries are arranged by ascending numerical order using, in most cases, the three-digit numbering system in vogue from about 1900 to the mid-1940s. Blocks which have been given five-digit, revised NCB numbers since the 1940s are usually referred to by their revised numbers. Within each subsection, the physical shape and boundaries of the block in question and any changes in those physical elements over time are first noted. A history of land transfer and development, and of the erection and/or modification of selected structures in the block is then presented. When available, the history of a selected family's or individual's activities as related to each block is given as an example of the broader spectrum of human activities which occurred there. In some cases, the last portion of each section contains a summary of the ethnic and class mix over time as related to structural developments in the block.

Five sources contained the majority of the data used for this report.

1) San Antonio city directories [CD], selected editions from 1877-1878 through 1901-1902;

2) Sanborn Map and Publishing Company, Limited's maps [Sanborn maps, SM] of San Antonio, selected editions from 1877 through 1911, and the 1952 edition;

3) Bexar Abstract and Title Company NCB transaction record sheets on file in the records plant of Stewart Title Company of San Antonio;

4) Augustus Koch's Bird's Eye View Map of San Antonio for the year 1886 (Figure 3-15; copy on file in the collections of the San Antonio Museum Association and at (AR); and

5) The San Antonio Light's Bird's-eye Sketch Map of San Antonio Texas, December, 1891 (copy on file at CAR).
The individual block maps were originally compiled by the S. A. Map Company, Charles Southwell Company, Owner, in about 1910 (M. L. Ferguson and W. P. Southwell, personal communication 1990).

General historical data were taken from various works on the history of San Antonio and Texas (Barnes 1910; Fehrenbach 1978; Steinfeldt 1979). Some of the property transfer information was obtained directly from the Bexar County Deed Records [BCDR] on file at the Bexar County Courthouse, San Antonio, Texas. Many details in the individual histories were obtained from birth and death records in the Metropolitan Health Department of the city of San Antonio files (City Hall, San Antonio, Texas), and from newspaper obituary columns.

\section{General Considerations}

Some information encountered during CAR's archival investigations of the Alamodome area-for example, a change in a street's name-is pertinent to the whole project area or at least to large portions of the area. Such data are presented in this section.

\section{Quantitative Block Data}

Over 14 lots were originally platted in the area using the district and range system implemented by the city of San Antonio ca. 1842 (Figure 1-2). Each lot was the equivalent of an NCB, and known correlations of present NCBs with the old lot numbers are presented in Table 6-1. Before the most recent changes in block numbers shown on the Baker survey map, all or portions of 17 NCBs were within the area.

The numbers and plan configurations of several of the blocks changed over time. What was originally all of NCB 601 and part of NCB 681 has been changed to NCB 14082. A large portion of what was once NCB 681 and a small area of NCB 682 were joined and renumbered as NCB 14081. Also, NCBs 605 and 606 have become, respectively, NCBs 14083 and 14084 .

In terms of size, configuration, and orientation, nine of the blocks were originally platted as squares with sets of parallel sides oriented on the cardinal directions. 
Table 6-1. Changes in City Block Designations

\begin{tabular}{|c|c|c|}
\hline $\begin{array}{c}\text { Original City } \\
\text { Lot Number } \\
\text { (assigned ca. 1842) }\end{array}$ & $\begin{array}{c}\text { Initial New City } \\
\text { Block Numbers } \\
\text { (assigned ca. 1900) }\end{array}$ & $\begin{array}{c}\text { Revised New City } \\
\text { Block Numbers } \\
\text { (assigned ca. 1945) }\end{array}$ \\
\hline 5 & 601 & 14082 \\
\hline 9 & 605 & 14083 \\
\hline 10 & 606 & 14084 \\
\hline 11 & 607 & - \\
\hline 16 & 613 & - \\
\hline 17 & 614 & - \\
\hline 18 & 615 & - \\
\hline 24 & 620 & - \\
\hline 25 & 621 & - \\
\hline 26 & 622 & - \\
\hline 30 & 627 & - \\
\hline 31 & 628 & - \\
\hline 32 & 629 & - \\
\hline 36 & 636 & \\
\hline
\end{tabular}

Note: Insufficient data was available for inclusion of NCBs 679, 681, and 682.

The 1985 Baker survey map (Figure 6-1) shows that the square blocks were about $419 \mathrm{ft}$ on a side. Therefore, each block would have contained approximately $175,561 \mathrm{ft}^{2}$ or 4.03 acres. On-site estimates made in 1990 by the CAR staff confirmed the general accuracy of these figures.

Of the nine blocks which were originally square, seven were still square in 1990 and two, NCBs 613 and 620, had been altered significantly by the construction of IH-37. The other eight city blocks in the area have had various geometric shapes over time. In addition to those already mentioned, the shapes of the following NCBs have been affected by the construction of IH-37: $627,682,14081$, and 14083.

\section{Street Designations}

Several streets within or bordering the area have had name changes or been rerouted or altered, and a few new streets have been added to the area at various times in the past. These changes were usually reflections of other contemporaneous structural or functional modifications of historical significance to the area. For example, the Galveston, Harrisburg and San Antonio Railroad came to San Antonio in 1877. Circa 1881 , the tracks were routed down the middle of Walnut Street, substantially altering the subsequent traffic patterns and use characteristics of the street and surrounding lands. Thus, much of the residential development in the area occurred after 1880.

Perhaps the earliest maps of the area which show the layout of many of the streets and blocks as they were first platted are the several versions of a "Plat of Lands on the East Side of the San Antonio River Sold by the City of Bexar" (Figure 1-2). The earliest of these is dated 1842 (copy on file at CAR), with later renditions in 1849,1853 , and 1855 . The 1842 copy of the map gives the original names of many of the present streets in the area. Commerce Street, which today forms the northern boundary of the area, was Avenue of the Alameda. The streets which extended north-south in 


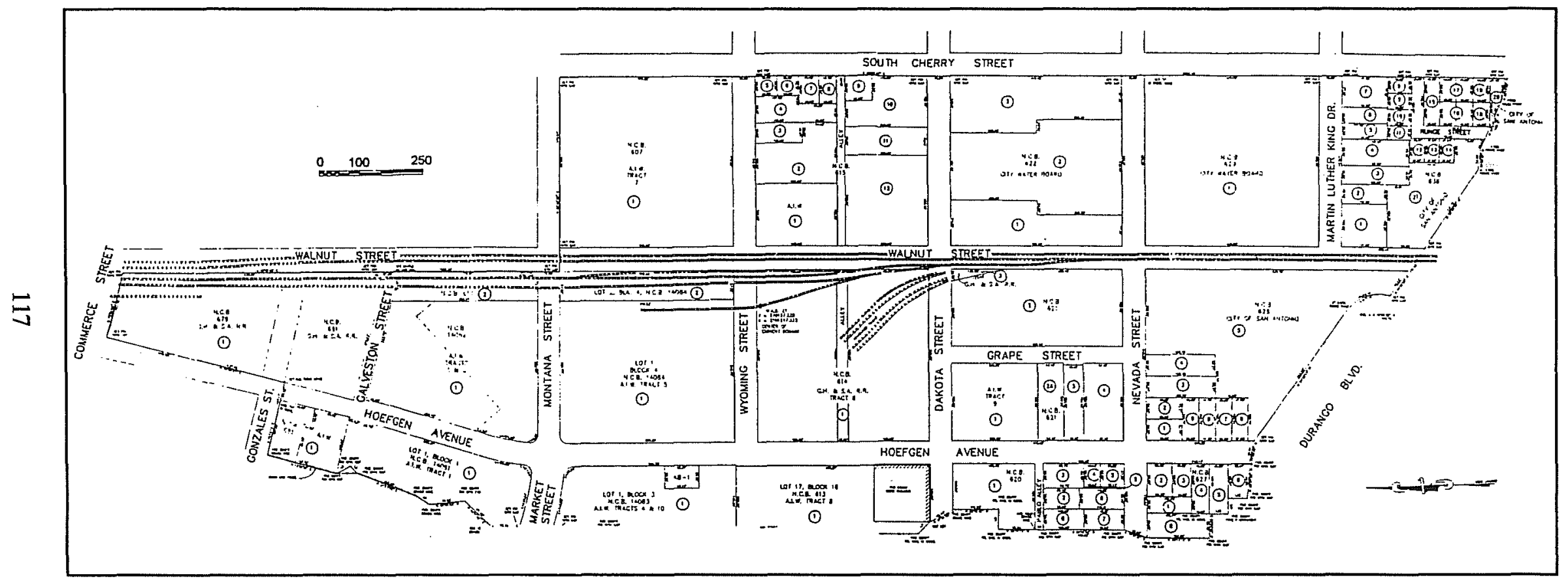

Figure 6-1. Plat of the Alamodome Project area. Map prepared by Amil M. Baker, Baker Surveying Company, May 1989. Copy on file at CAR. 
the area, i.e., Plum, Walnut, and Cherry, bore the same names; however, the streets which ran east-west were initially South 1st through South 7th Streets. The latter were renamed sometime after the end of the Civil War and before 1877, starting with what was South 1st Street on the north and proceeding south: Idaho, Montana, Kansas, Wyoming, Dakota, Nevada, Nebraska, and Iowa streets.

Other changes in street names or additions of new streets within the area occurred. In 1858 , with the beginning of broader-scale residential development in NCB 621, an alley (which became Grape Street in 1903) was opened. Similarly, in 1897, Eda Street was constructed within NCB 607 and, in 1918, Runge Street was added to NCB 636. Eda Street was changed to Wells Street in 1915 and was closed sometime after 1952 to facilitate further expansion of Alamo Iron Works into NCB 607. Also, in 1915, Plum Street was renamed Hoefgen Avenue. In 1925 the portion of Santa Clara Street that originally passed through the area was closed due to northward expansion of Alamo Iron Works. Durango Boulevard along the southern boundary of the area was a portion of Goliad Road until 1891, when it was incorporated into the eastern extension of Victoria Street. It became Durango Boulevard in about 1967. Nebraska Street was renamed Martin Luther King Drive in the early 1970 s.

\section{Individual Block Descriptions}

\section{NCB 14082}

The portion of this block which was once designated NCB 601 was triangular-shaped and was bounded on the north side by Santa Clara Street (the line of which ran roughly southwest to northeast), on the south side by Montana Street, and on the east side by South Walnut Street (Figure 6-2). It retained this shape and boundaries until 1925, when Santa Clara Street was closed and a piece of land of nearly mirror-image proportions was added to it. From that time forward the new physical block thus formed had been officially included in NCB 681 until recently, when NCB 681 was changed to NCBs 14081 and 14082 . The latter are designated on the Baker survey map as Alamo Iron Works Tracts 1 and 2. The whole block was thenceforth trapezoidal in shape, with a new western boundary at Hoefgen Avenue and a new northern boundary on Galveston Street. The NCBs surrounding 601 initially included 681 to the north and northwest, 682 to the west, 605 to the southwest, 606 to the south, 607 to the southeast, and 602 to the east.

The following historical information pertains to NCB 601. The block was first purchased from the city of San Antonio in 1850 by James W. Gray. Gray did not subdivide or develop the property. In 1883 he applied to the city for a reissue of the deed because he had lost the original. Immediately after the deed was reissued, Gray sold the block to J. B. Lacoste. The following year George Holmgreen purchased the property for the new location of his iron works, Holmgreen and Sons, later Alamo Iron Works. Thus the block never underwent much residential development.

Holmgreen's background is summarized in an obituary which appeared in the San Antonio Light newspaper on November 8, 1899.

Deceased was a native of Germany, being born in Berlin October 4, 1822. He came to the United States as a young man. He landed at New Orleans. During the Civil War he had charge of the United States naval works at New Orleans. At the close of the war he went to Pensacola, Fla. He came to San Antonio in 1878. Deceased came from a family of mechanics. His father was an inspector of buildings for the royalty in Berlin. A brother of the deceased is government railroad constructor at St. Petersburg, Russia, and another brother, who was also a mechanic, has retired at Berlin . . . Deceased was a member of the Beethoven society.

Holmgreen began developing NCB 601 into the iron works business immediately after he purchased it in 1884. During the rest of his lifetime, he expanded the physical structures and components of Alamo Iron Works within the block, and his sons carried on with the expansion outside the block after his death. The enterprise eventually encompassed more than 17 acres, including all of NCBs 601, 606, and 614, and substantial portions of NCBs $605,607,681$, and 682 .

By 1886 , only two years after Holmgreen purchased NCB 601, Koch's Bird's Eye View of San Antonio (Figure 3-15) shows a very large, two-story commercial structure with an attached one-story auxiliary structure, toward the north end of the block 


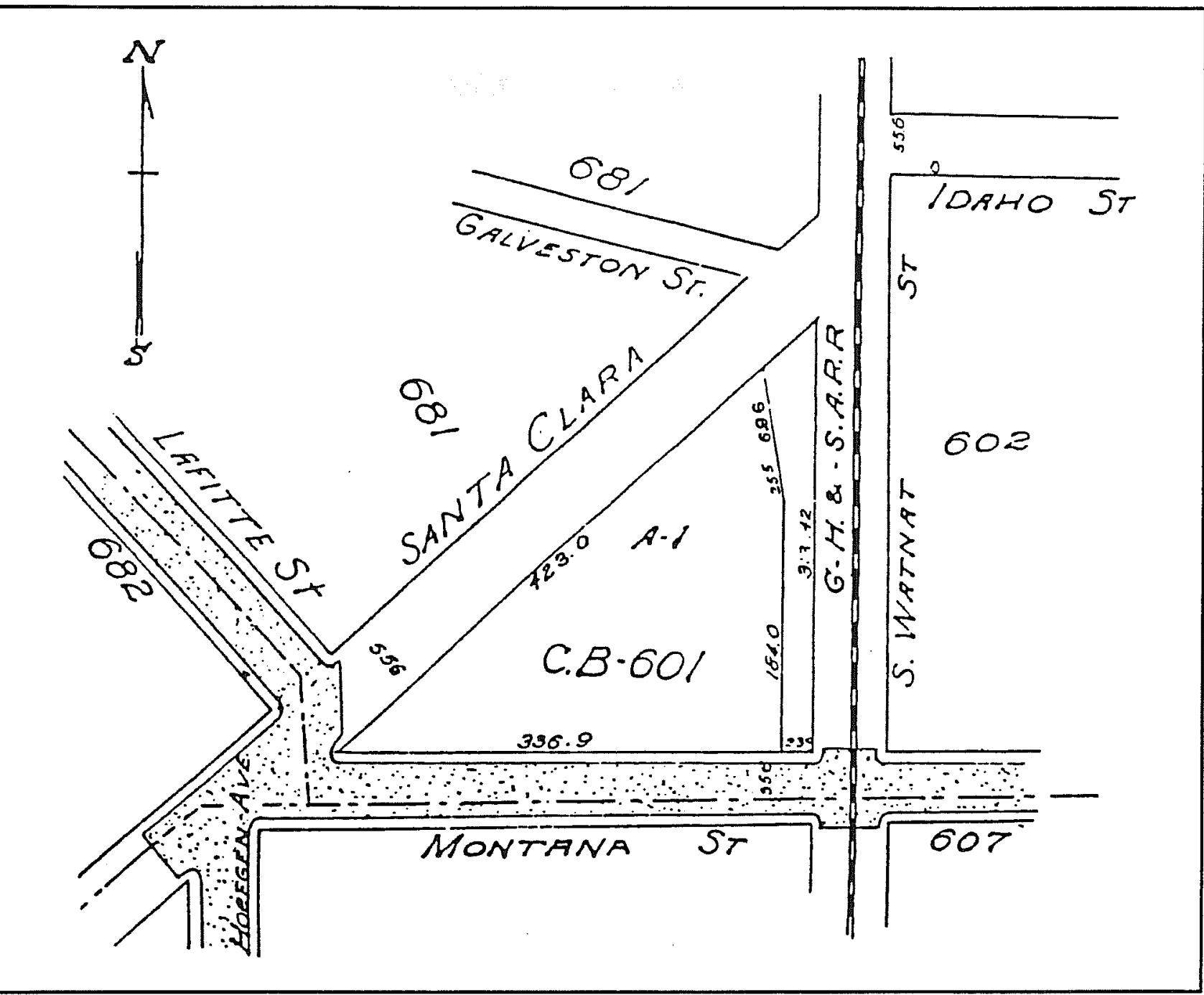

Figure 6-2. Plat of NCB 601, ca. 1910. S. A. Map Company.

near the intersection of Santa Clara and South Walnut streets. This was apparently the original foundry (SM 1892, 1896, and 1905). The map also shows two smaller, free-standing, two-story buildings along Santa Clara Street. One is in the approximate middle of the block, the second is toward the south end of the block near the intersection of Santa Clara and Montana streets. The building in the middle of the block was probably an office, the second, smaller structure was probably a residence (SM 1896).

The San Antonio Light's Bird's-eye Sketch Map of San Antonio shows an entirely different configuration of physical structures within the block. A very large, Lshaped, two-story building with an adjacent one-story auxiliary building is shown near the southwest corner of the block. The long side of the two-story building is shown facing northwest onto Santa Clara Street and its short side faces southwest toward the intersection. The attached one-story building is near the end of its short wing, which faces southeast. Two smaller, freestanding, two-story buildings are on the other two corners of the block. Chimneys of commercial proportions with plumes of smoke rising from them are protruding from the roofs of all but the building on the southeast corner of the block. Both earlier and later Sanborn maps (cf. 1885, 1892, 1896, 1905, and 1911) agree with Koch's 1886 version and portray virtually identical arrangements. Thus, the accuracy of the newspaper's map regarding NCB 601 structures is questionable. 
Land and Thompson (1885:104) offer the following description of the five Alamo Iron Works structures which existed in NCB 601 in 1885:

The buildings, which are all new and especially constructed for the purpose, consist of the foundry, 30 by 80 feet in size; cleaning room, 30 by 35 feet; blacksmith shop, 20 by 35 feet; store room, 20 by 65 feet; and machine shop, 35 by 70 feet, two stories in height.

Three years later, the Iron Works consisted of a total of nine buildings: the foundry and machine shop and seven additional support structures (SM 1888). By 1892 , the complex remained mostly the same as in 1888, but the machine shop had been enlarged (SM 1892).

The 1952 Sanborn map indicates that the then-existing Alamo Iron Works sales and stockroom was built in 1917. It also reveals that almost all the original buildings had been radically altered, converted, or removed between then and 1952. The foundry had been moved to a new location in NCB 606 (the block immediately south of NCB 601, now NCB 14084) at the corner of Wyoming and South Walnut streets. Also by 1952 , all of NCB 601 was covered by a portion of Alamo Iron Works building complex which contained the watchman and electrical power central control stations, shipping department, general storage for steel pipe and machinery, and sales and stock rooms. An article which appeared in the San Antonio Light on Sunday, May 24, 1953, describes the land and building components then included in the Iron Works:

The original tract of one acre has been added to make the present San Antonio plant site eight acres. The firm's plants . . . contain a foundry, structural and reinforcing fabricating shop, modern welding plant and a machine shop . . . Alamo's San Antonio headquarters has a centralized concentration of sales, service, and engineering functions-one of the largest single plants of its kind in the country.

After 1895 a two-story frame building for the Acme Ice Cream Company at the corner of Montana and Santa Clara streets was added to the block. By 1896 a dwelling and dependency were also at that location.
In addition to the above-ground structures mentioned, two excavated acequias apparently skirted the block. The first, a lateral or branch of the original Alamo Acequia or Acequia Madre, passed just west of and parallel to Santa Clara Street near its intersection with Lafitte Street. This acequia was constructed by the Spanish in the 1730 s. The second was the Valley Ditch, a small irrigation and storm drainage canal built by the city of San Antonio around 1874, which ran down the west side of Walnut Street (and which also extended along the eastern edges of NCBs 606, 614, 621 , and 628). Nothing was found during the archival research to indicate the precise cross-sectional size or shape of the segments of these ditches which pass through the study area.

\section{NCB 14083}

As NCB 605 this block was triangular in shape (Figure 6-3), and was bounded on the northwest side by Santa Clara Street (the line of which ran essentially southwest/northeast), the south side by Wyoming Street, and the east side by Plum Street. The shape remained virtually unchanged and those streets continued to be its boundaries until Plum Street was changed to Hoefgen Avenue in 1915 and $\mathrm{HH}-37$ was constructed in 1967. The construction of the interstate radically altered both the size and configuration of the block. A large section on the west was usurped by the expressway, the portion of Santa Clara Street abutting the block was closed, and the shape of the block changed to its present rectangular form. Adjacent blocks initially included NCBs 682, 691, and 875 to the north; 601 and 681 to the northwest; 606 to the east; 614 to the southeast; 613 to the south; 612 to the southwest; and 695 to the west. The Baker survey map shows NCB 14083 as Alamo Iron Works Tracts 4 and 10.

NCB 605 was purchased from the city of San Antonio by Charles Fisher, who simultaneously purchased NCB 613, on October 3, 1850. The former was sold by Fisher to Carl E. Kreische in 1851. In the early 1880 s, Kreische began subdividing and selling lots to individuals. Thus, all of the structures in NCB 605 were built after that time. During its residential phase of development, the block was eventually divided into eight primary lots (Figure 6-3); a few of those were 


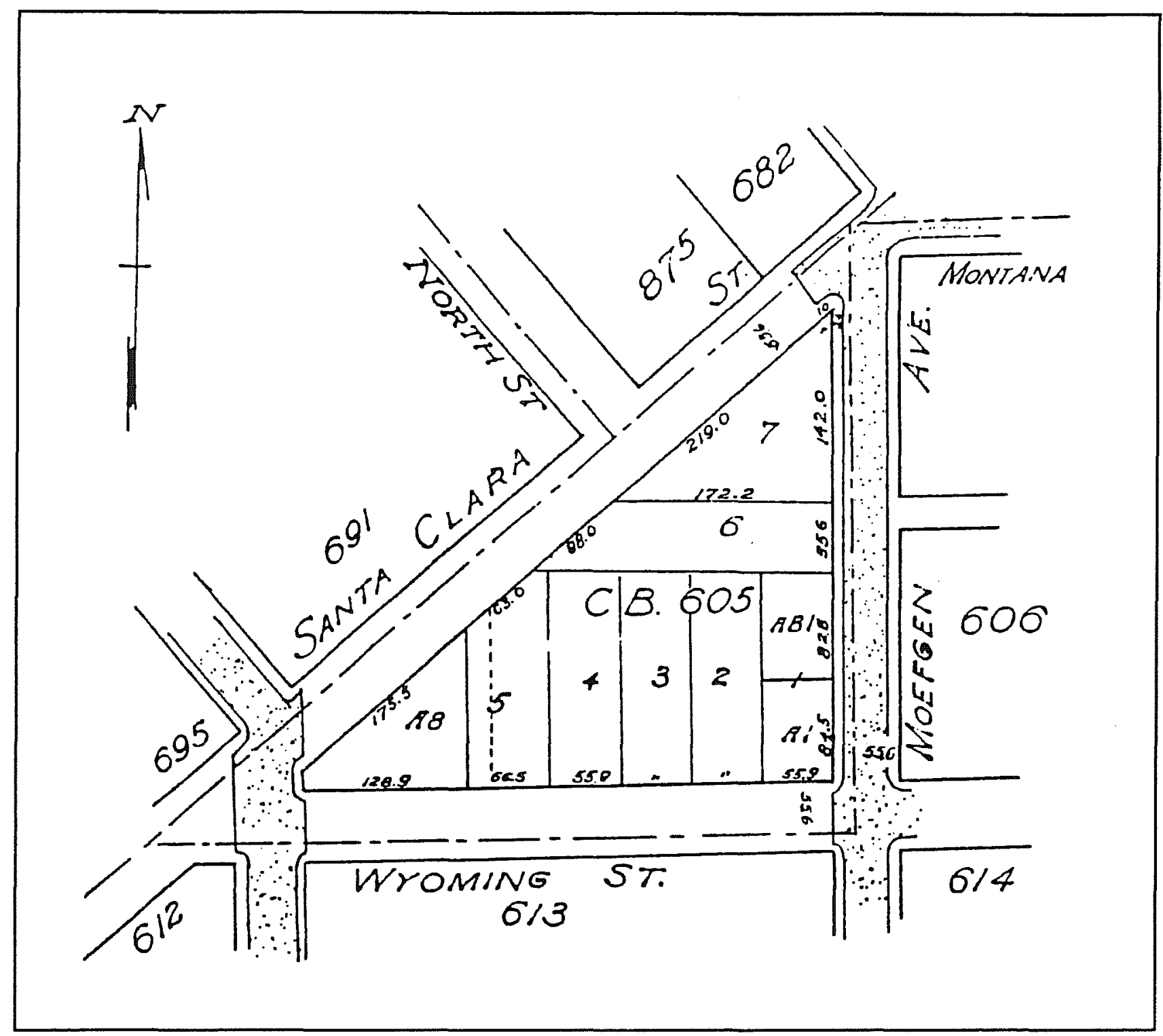

Figure 6-3. Plat of NCB 605, ca. 1910. S. A. Map Company.

replatted, forming several additional lots. All the lots had acquired at least one dwelling by about the turn of the century, and several also had auxiliary dwellings and/or outbuildings. As far as can be ascertained from the records examined, the block never developed much commercially until after the mid-twentieth century. The 1952 Sanborn map shows about a dozen residences and one store on the block. Finally, the entire block was purchased by Alamo Iron Works and converted to commercial manufacturing or storage buildings and associated outside parking and loading or yard storage areas.
The Stendebachs are fairly typical of the Germanic couples or families which settled and built homes in the area during the early period of nineteenth-century residential development. The Bexar Abstract and Title Company transaction records indicate that Mrs. Elise Starndebach or Stendebach purchased Lot 1 in 1881. She and her husband Joseph built a home on the south half of Lot 1 shortly afterward. The 1881-1882 city directory lists her as residing on the north side of Wyoming Street between Santa Clara and Chestnut streets. No information is available from the consulted sources regarding Joseph's occupation. 
Joseph died in either 1889 or 1890 . In 1891, Elise transferred the south half of Lot 1 to Adolph Klar and, from that time forward, the Stendebach name does not appear in the transaction records for the block. Since the Stendebachs had already sold the north half of Lot 1 to William F. Eckenroth and wife in 1889, it seems reasonable to assume that the 1891 sale of her home on Wyoming Street marks the widow Stendebach's permanent departure from the neighborhood.

In addition to Eckenroth, Klar, Kreische, and Stendebach, the following surnames apparently of Germanic heritage appear as grantors and/or grantees in the nineteenth century deed records for NCB 605: Clauss (Lot 4, 1883); Zuercher (Lot 2, 1883); Umscheid (Lot 6, 1890 and 1899); Stachelhauser and Klatt (south half of Lot 1, 1893); Bach (south half of Lot 1, 1896); Guenther (Lots 5 and 8, 1896); Mauermann (south half of Lot 1, 1896); and Oeffinger (Lot 5, 1897). Although a few of the names are designated as assignees or trustees, most were owneroccupants of properties with residential improvements in the area.

The trend of settlement and ownership primarily by those of Germanic origin continued within NCB 605 into the early decades of the twentieth century; however, the percentage of persons associated with the block with surnames which are clearly of Germanic origin began to steadily decline after the first quarter of the century. Because there is a marked decline or total absence of designations of racial origin in city directories beginning in about the third quarter of the nineteenth century, it is generally more difficult to determine from the directories the ethnic mix or national origins of any block's inhabitants after 1900 .

Although blacks may have had a significant influence on the history of the area, they seem to have comprised a very small percentage of the property owners and occupants in the general area before 1900 . While there are several ethnic groups associated with NCB 605 other than Germans and blacks, by the time these groups inhabited the block most of its structural characteristics had already been established, primarily by the Germans.

\section{NCB 14084}

The original square plan of this block, which was formerly NCB 606, has not changed to the present time. Before Alamo Iron Works bought the block, Morrison Alley extended east-west, bisecting the block into rectangular halves. Prior to 1915 , the year that Plum Street was renamed Hoefgen Avenue, the boundaries of the block were Montana Street on the north, Wyoming Street on the south, South Walnut Street on the east, and Plum Street on the west (Figure 6-4). Blocks surrounding NCB 606 originally included NCBs 601 on the north, 602 on the northeast, 607 on the east, 615 on the southeast, 614 on the south, 613 on the southwest, 605 on the west, and 682 on the northwest.

As NCB 606, the block was purchased from the city of San Antonio by James M. Devine in 1851. He had purchased NCBs $607,615,620$, and 622 the previous year. Devine was a prominent public figure in San Antonio, serving as mayor in 1856-1857. He sold the entire block to H. D. Stumberg in 1867. Stumberg subdivided the tract into 16 lots and began selling them to individuals in 1877 . By 1885,11 of the lots had been purchased. Homes were constructed on the entire western portion of the block between 1878 and 1886 . Data on eight of these structures are presented in Table 6-2. Alamo Iron Works later purchased the block by acquiring these lots and homes individually between 1908 and 1965. The block is designated on the Baker survey map as Alamo Iron Works Tract 5 . In addition to the residential and commercial developments which occurred in NCB 606, a branch of the Valley Ditch was probably located along its eastern edge.

Germans constituted a plurality in the block in the early part of its residential development. Anglos were only a slightly lesser proportion. Those having Irish, French, and Polish surnames were also present but constituted a very small minority. The Meades, who purchased Lot 14 in 1882, were perhaps the first black homeowners to reside in the Alamodome area.

Gustave Mintel's business, which began as a machine shop, is a fairly typical example of the small-scale, German-owned enterprises which operated during the 


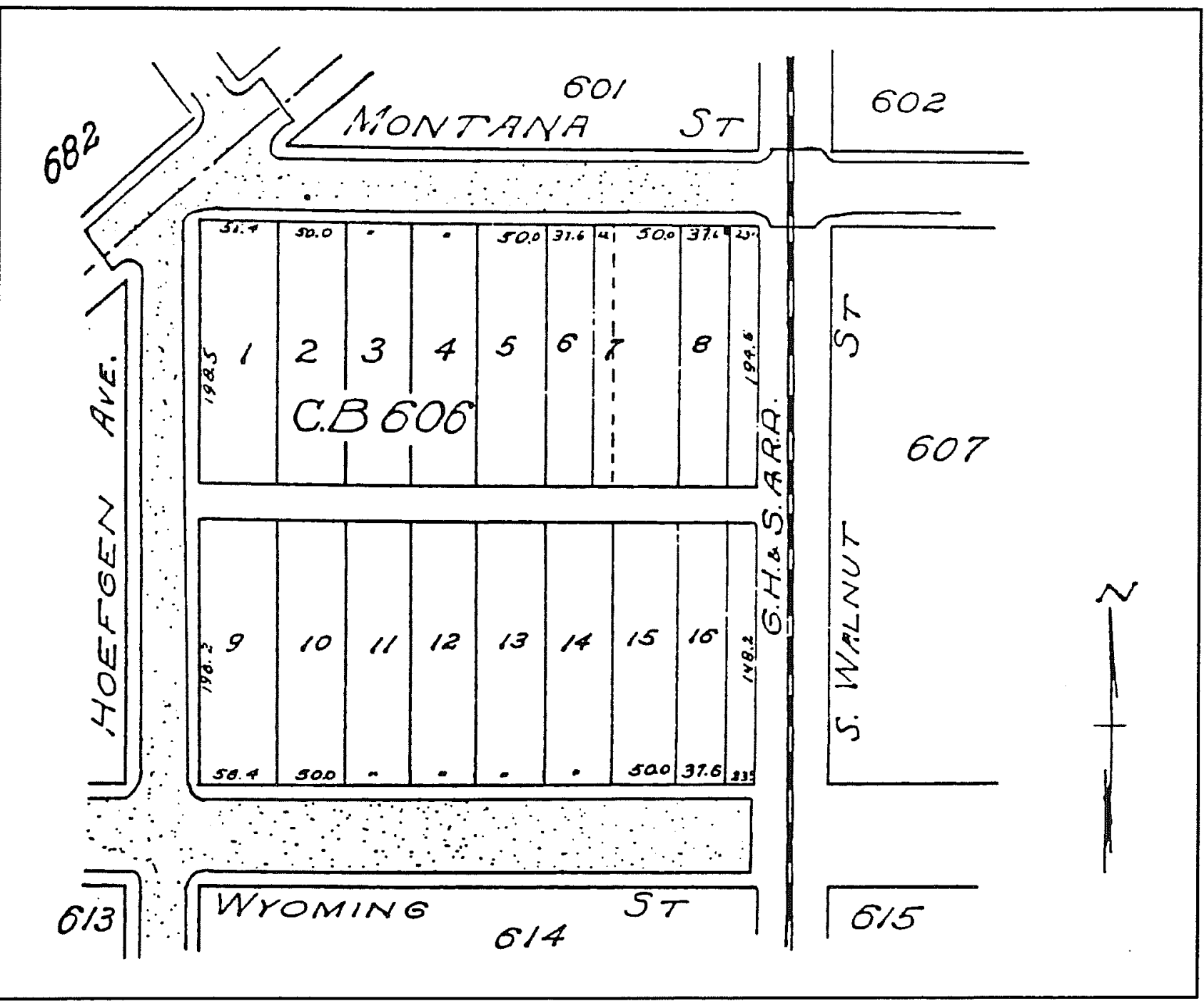

Figure 6-4. Plat of NCB 606, ca. 1910. S. A. Map Company.

Table 6-2. Data on Selected Nineteenth-Century Residences in NCB 14084

\begin{tabular}{|c|l|l|l|c||}
\hline $\begin{array}{c}\text { Lot } \\
\#\end{array}$ & \multicolumn{1}{|c|}{ Address } & \multicolumn{1}{|c|}{ Type } & \multicolumn{1}{|c|}{ Owner } & $\begin{array}{c}\text { Approximate } \\
\text { Construction Date }\end{array}$ \\
\hline 2 & 106 Montana & 1-story frame & Joseph and Wilhelmina Huppetz & 1883 \\
\hline 3 & 112 Montana & 1-story frame & Charles Jonas & 1884 \\
\hline 4 & 116 Montana & 1 -story frame & William Jonas & 1884 \\
\hline 9 & 203 Wyoming and 118-120 Plum & 1 -story frame & Gustave and Wilhelmina Mintel & 1886 \\
\hline 11 & 206 Wyoming & 1 -story frame & Fritz Biesenbaum & 1878 \\
\hline 12 & 213 Wyoming & 1 -story frame & A. W. and Augusta P. Morris & 1881 \\
\hline 13 & 215 Wyoming & 1-story frame & A. W. and Augusta P. Morris & 1883 \\
\hline 14 & 219 Wyoming & 1-story frame & Willis and Katie Meade & 1882 \\
\hline
\end{tabular}


late-nineteenth and early twentieth centuries in San Antonio. Its history illustrates the general evolution and structural impact over time of such an enterprise within a small area. Mintel worked for George Holmgreen and Sons (later Alamo Iron Works) from about 1883 to 1896 (CDs 1883, 1885, 1887, 1889, 1897). His mother Wilhelmina, widow of William Mintel, is shown in transaction records to have purchased Lot 9 from H. D. Stumberg in 1886. The lot was rectangular and extended along Plum Street between Morrison Alley on the north and Wyoming Street on the south.

The Mintels built the home at 203 Wyoming Street around 1886. By 1897 Gustave had left the employ of Alamo Iron Works and opened his own shop at $118 / 120$ Plum Street on the north half of Lot 9. The machine shop continued to operate from that location until it was converted to an electrical repair shop about 1905. In 1909, Gustave's son Otto joined him in the electrical repair business and, by 1914 , the business had expanded to include the retailing of electrical supplies.

In 1922 S. B. Hammond and Otto Mintel opened Mintel Electrical Sales at 728 South Alamo Street, while Gustave continued operating as an electrician from the old address on Hoefgen Street. A partnership to engage in the electrical business between Gustave and Otto Mintel and F. A. Menger was formed by 1926. Otto and his wife Edwina opened a separate business called the Electrical Store in 1931. Gustave Mintel continued to be listed as an electrical supplies retailer at the address on Hoefgen Street in city directories until after 1935. Wilhelmina died in 1917, yet the property remained in the Mintel family until it was sold in 1948 to Alamo Iron Works by the estate of Gustave's wife Louisa.

Information on the history of black activities in the study area has been systematically collected by the CAR research team using data from various archival records and oral interviews. The historical significance of an early and isolated but relatively successful black occupation of the area, such as the Meades represent, is yet to be determined. At any rate, the Meades made what is perhaps the first black impact upon the structural history of the area, and the more immediate contexts and events of their lives are therefore noteworthy.
Preliminary information indicates that Willis Meade, Sr., and his wife Katie built their home at 22 (later 219) Wyoming Street shortly after the purchase of Lot 14. Although city directory occupation records on the Meades are somewhat unclear, it seems that Willis, Sr., was an agricultural laborer from at least ca. 1883 through ca. 1889. By 1897 Willis, Jr., is listed in the directory as a "driver" (typically meaning a carriage driver) for Ben Moke, owner of Moke's Millinery Parlor located at 333 West Commerce Street. Willis, Jr., again shows up as a driver in the 1901-1902 city directory, that time for Washer Brothers Clothing Store, 108-110 East Commerce.

Apparently Willis, Sr., died sometime in the 1890 s; by 1897, Katie is listed as the "wid [of] Willis Sr," still residing at 219 Wyoming Street. Transaction records indicate that the Meade home was sold to one J. H. Nass in 1911. Nass must have encountered financial difficulties shortly after purchasing the home. He was in receivership by 1913 and various Meades including Kisha, Francis, and Willis are shown as civil litigants against him at about that time. He managed to hold onto the property and finally sold it to Alamo Iron Works in 1915, which is also the year in which Katie Meade died. From that year forward, there is no record of the Meades' presence in NCB 606.

Transaction records (Bexar Abstract and Title Company) indicate that Alamo Iron Works acquired the other lots in NCB 606 as follows: Lot 15 in 1908; Lots 5, 6, 7, 8, and 16 in 1910; Lot 2 in 1916; Lots 12 and 13 in 1917; Lots 3 and 4 in 1918; Lot 11 in 1919; Lot 10 in 1925; and Lot 9 in 1948. The Iron Works sold the east $23 \mathrm{ft}$ of Lots 8 and 16 (having almost $400 \mathrm{ft}$ of frontage on the west side of South Walnut Street and the existing rail lines) to the Galveston, Harrisburg and San Antonio Railway Company in 1910. In about 1925, it conveyed additional land in NCB 606 to the railroad, portions of Lots 7, 8, 15, and 16. The 1952 Sanborn map shows that by that time Alamo Iron Works had developed the entire block commercially (SM 1952). Improvements then included a pattern shop, machine shop, pipe shop, welding and plate shop, forge shop, reinforcing bar shop, structural shop, erecting shop, lumber shop, and molding and foundry departments. 
NCB 607

NCB 607 was one of the original square blocks in the area, and had a north boundary at Montana Street, a south boundary at Wyoming Street, an east boundary at South Cherry Street, and a west boundary at South Walnut Street. In 1897 the block was divided into two rectangular sections by the construction of Eda Street. This street was oriented north-south and separated about the western one-third from the rest of the block. After its construction, the basic physical configuration of the block (Figure 6-5) remained unchanged until sometime after 1952 (SM 1952). Eda Street was first renamed Wells Street in 1915 and, as Alamo Iron Works expanded further eastward into the block, was later closed. The block was originally surrounded by the following adjacent NCBs: 602 on the north, 603 on the northeast, 608 on the east, 616 on the southeast,
615 on the south, 614 on the southwest, 606 on the west, and 601 on the northwest. It is designated on the Baker survey map of the area as Alamo Iron Works Tract 7.

NCB 607 was one of several blocks in the area first purchased in 1850 from the city by James M. Devine, a prominent San Antonian and later mayor (see NCB 605). Only a few months after purchasing the block, Devine sold it to another well-known early San Antonian, James H. Kampmann. Barnes (1910:143, 223, 236) and Steinfeldt (1979:90) provide the following information regarding Kampmann. He was a native of Prussia who obtained boyhood training in Cologne, Germany, in carpentry, blacksmithing, stonemasonry, and plastering. He came to San Antonio in 1848 , and soon after arrival began an architectural and building business. During the Civil War,

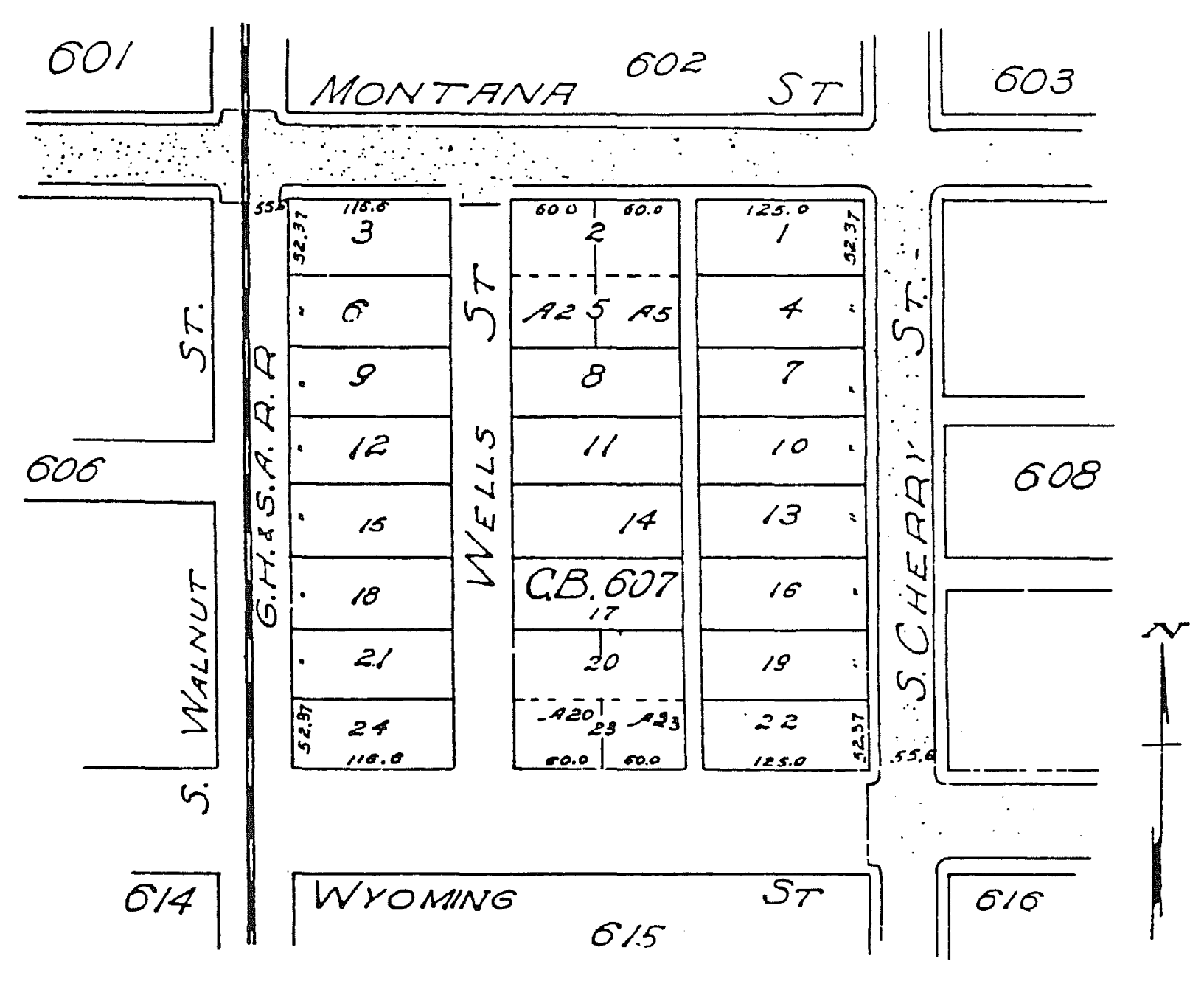

Figure 6-5. Plat of NCB 607, ca. 1910. S. A. Map Company. 
Kampmann served as a major in the Confederate cavalry under the command of Henry E. McCulloch. After the war he returned to San Antonio and opened a factory and planing mill to make doors, sashes, and blinds. Over the course of a lengthy business career, he constructed many notable edifices including the Menger Hotel, the Alamo Literary Hall (later the Bexar Hotel), the Kampmann Building, St. Joseph's Church, and the King William Street home of Albert Steves (Waynne Cox, personal communication 1990).

According to Bexar Abstract and Title Company's transactions records, after Kampmann's death his wife Caroline began subdividing the block and selling residential lots in 1894. The 1891 bird's-eye sketch map of San Antonio shows one structure located toward the northeast corner of the block; however, there is no evidence of the existence of that structure in any of the other records examined. By 1911 there were about two dozen free-standing residential dwellings on the block and at least as many detached outbuildings (SM 1911). Virtually all these dwellings were one story with wooden frames and exterior trim and composition or metal roofs.

During this late-nineteenth- to early twentieth-century period of development, a few small businesses opened toward the western end of the block along the east side of South Walnut Street and along the north side of Wyoming Street. They included a store and two saloon/store combinations which apparently operated from converted residences (SM 1905, 1911). No largescale commercial or industrial development occurred in the block until Alamo Iron Works purchased the land between Wells and South Walnut streets, closed the former, and converted the land so acquired to a scrap iron and pipe storage facility. Later, Alamo Iron Works purchased the entire block and converted the storage facility to a large modular-style warehouse. The rest of the block was reduced to a parking lot interspersed with a few small free-standing storage sheds.

\section{NCB 613}

When first formed, this block was square with parallel east-west and north-south sides (Figure 6-6). It was bounded on the north by Wyoming Street, on the south by Dakota Street, on the east by Plum Street, and on the west by Peach Street. Surrounding NCBs included 605 on the north, 606 to the northeast, 614 on the east, 621 to the southeast, 620 on the south, 704 to the southwest, 612 on the west and 695 to the northwest. The building of IH-37 in 1967 converted approximately the western half of the block to the expressway and associated right-of-way. Apparently neither the original block nor the rectangular version resulting after the construction of the highway was ever altered by internal throughways or alleys. The block is designated on the Baker survey map of the area as Alamo Iron Works Tract 8.

This block was first purchased from the city by Charles Fisher, who bought it and NCB 605 on October 3, 1850. Fisher then sold both blocks to Charles Kreische in late 1851. Kreishe soon subdivided NCB 613 and began selling lots to individuals with the purchase of Lots 10-13 by Hermann Schulze in November 1854. By 1861, all 16 of the primary lots in the block had been sold at least once, and Lots 3 and 4 had been further subdivided.

By 1905 about 15 single-family residential dwellings and a multi-family tenement were located in the block, all free-standing structures, and numerous detached outbuildings were also present. All of the commercialization which occurred in the block seems to have happened after 1911 (SM 1911). By 1952 there were almost no single-family, owner-occupied residential dwellings left in the block (SM 1952). The H. W. Lewis Equipment Company extended along nearly the entire frontage of the block on Hoefgen Avenue (formerly Plum Street) and much of the frontage along Wyoming and Dakota streets. It had the following components at that time: a large tractor and machinery repair shop, a large road machinery warehouse, tractor sales and parts departments, and a welding shop and wash rack. There was also a restaurant on the northeast corner of the block at 532 Wyoming or 401 Hoefgen, and several of the block's former homes had been converted to apartments. Alamo Iron Works eventually purchased the Lewis Equipment Company's property and converted the large equipment sales and storage warehouses to iron and pipe storage and processing facilities.

Three residential structures along Wyoming Street were originally of "adobe" (SM 1905). On Sanborn maps, "adobe" usually meant that the exterior walls were plaster or stucco veneer over soft limestone or 


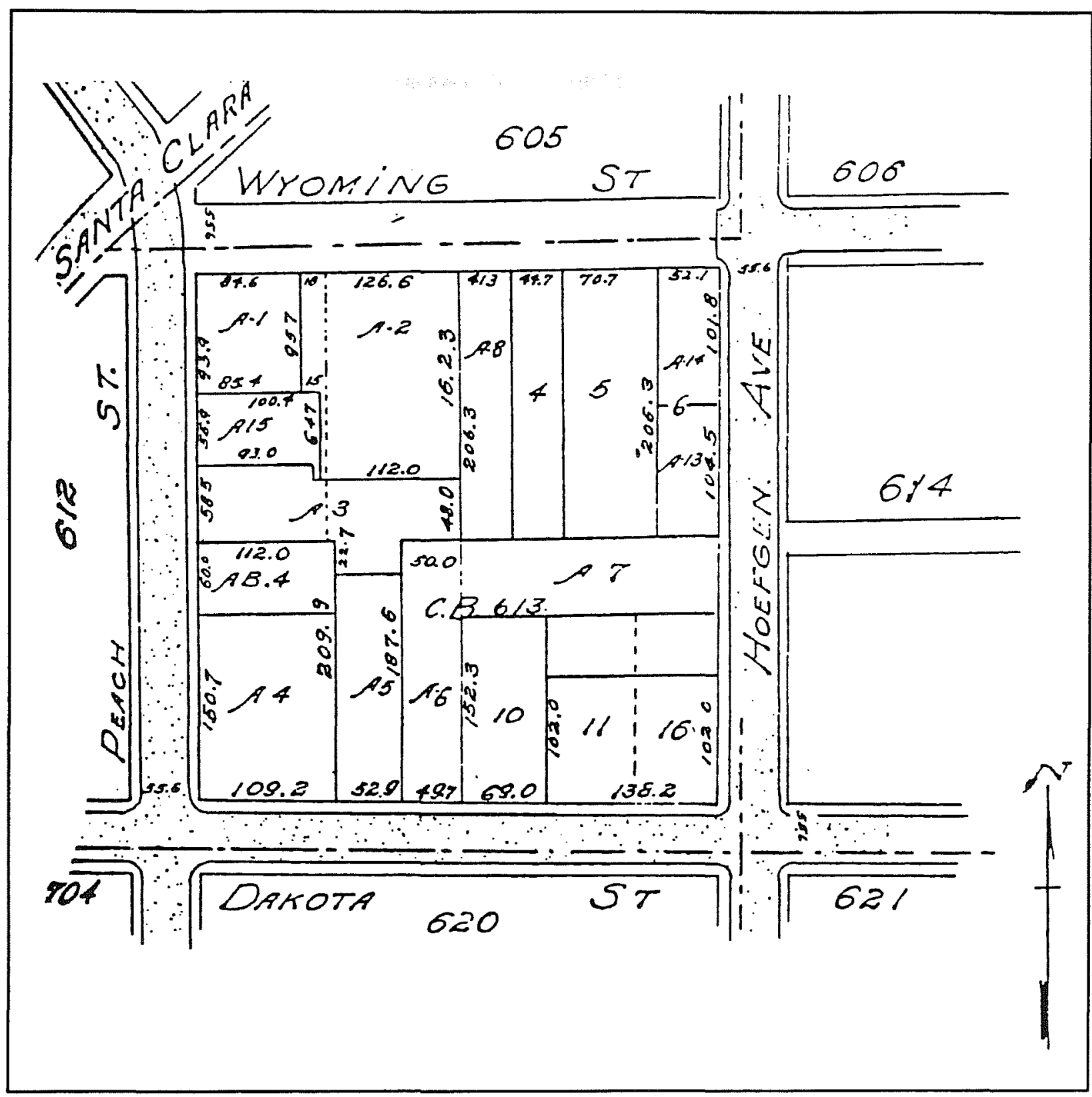

Figure 6-6. Plat of NCB 613, ca. 1910. S. A. Map Company.

caliche quarry blocks set in mortar. This was an index construction technique for homes dating roughly from the Spanish Colonial period through the immediate post-Civil War period in San Antonio. Since these were probably some of the earliest structures built in the area, details of their histories are included below.

The home which is shown on the 1905 Sanborn map at 122 Wyoming (Block 613, Lot 4) was probably built in the early $1850 \mathrm{~s}$. As the following account relates, and perhaps under some rather unusual circumstances,
Charles Kreische sold unimproved land in the block to John C. Houzeau in two different parcels: the east 18.5 varas of Lot 4 in March of 1859, and the west four varas of Lot 4 about one year later. Houzeau then sold all of Lots 3 and 4 to Peter Biesenbach in early 1862. Houzeau probably acquired the remaining portions of the lots from Kreische in the intervening time via unrecorded instruments. Biesenbach's attorney sold portions of both lots to William Ernst less than six months later. Ernst and his wife conveyed their parcels to Agnes C. Cotton in early 1863 . For 
reasons stated below, the next transaction entry on these parcels is the registration of a deed of trust to an unnamed "Trustee of Alexander Sarton [sic], Jr" granted by "Jacob Colbrun and Refugia Colbrun." The Colbruns had acquired all of Lots 3 and 4 from "M. G. Cotton \& wf" only a little over a year after John Houzeau had conveyed both lots to Peter Biesenbach. The Cotton's acquisition must also have been made via unrecorded instruments. The Cottons are not shown again in the records for the property.

The explanation for the Colbrun to Sartor deed of trust is found in the Bexar County Deed Records Volume S-3 (381-383), entry 244, which recorded the deed of trust and also set forth an interesting agreement between the Colbruns and Alexander Sartor, Jr. By that agreement, Jacob Colbrun was to serve either a three-year term in, or "until regularly discharged therefrom," the Confederate States Army as a substitute for Sartor, who had been drafted. Sartor paid the Colbruns "Thirteen hundred and fifty Dollars one thousand in Confederate money \& three hundred \& fifty in gold" which they would be allowed to keep without further obligation if Jacob Colbrun successfully completed Sartor's term of duty. As security for Jacob's performance, the Colbruns pledged their property, which either Sartor himself, or his trustee A. Staake, could "sell . . . to the highest bidder for cash before the Courthouse Door of Bexar County" in the event of a breach.

Jacob Colbrun apparently served the term and returned to reclaim his property. This is evidenced by a warranty deed recorded August 29, 1865 , conveying the property from the Colbruns to Gottlieb Glaeser. Also on that date, a mortgage was recorded between Glaeser as mortgagor and Carl Wrace as mortgagee. Unfortunately, none of this information establishes precisely when or for whom the home on Lot 4 was built. Even though neither Jacob nor Refugia Colbrun ever appears in the San Antonio city directories, it is possible that she was living in the adobe home on Lot 4 during her husband's military service.

Another adobe home in NCB 613 was on Lot 5 at 128 Wyoming Street in 1905. Lot 5 was first sold as a single parcel to Jacob Renz in February 1857. Apparently, Renz built a home there between April 1857 , when the first recorded mortgage was placed on the property, and March 1858, when the mortgage was released. Renz probably never occupied the home. In October 1858, he sold the homestead to Joseph C. Biesenbach, who occupied the property until his death, ca. 1891. Although these latter facts regarding Biesenbach are clear from the transaction records, neither he nor Jacob Renz is listed in any of the five city directories between 1877 and 1897 . Finally in the 1901-1902 city directory, Jacob Renz is listed as "driver City Brewery, r 210 Crosby." Sometime between 1911 and 1952, the home was removed, probably to accommodate the opening or expansion of the H. W. Lewis Equipment Company (SM 1911, 1952).

The third adobe structure in NCB 613 was located on Lot 6 at 132 Wyoming Street in 1905. Lot 6 was first sold individually by Charles Kreische to Jacob Rilling, a tinsmith, in 1855 . It is probable that Rilling never occupied or improved the property during the nine years he owned it. The property passed through several other ownerships between the time that Rilling sold it in 1864 and the time that the first recorded deed of trust on Lot 6 appears in the transaction records in 1872. That deed of trust was not permanently released until 1890 . During the intervening period and slightly beyond, the property passed through a rather long chain of short-term owners and the northeast section of Lot 6, which measured $20 \times 75$ varas, was platted and conveyed separately.

The majority of inhabitants of NCB 613 from the midnineteenth through the first quarter of the twentieth centuries were of Germanic descent. The next most numerous ethnic group were Anglos, which seem to have been about 30 percent of the population. There is no evidence at this time that other ethnic groups were represented within the mix, with the exception of a Jew, H. Shapiro, who owned the property at 118 Wyoming Street ca. 1911.

Occupations of Germans in the block reflect a working-class orientation. Those occupations, as listed in city directories between 1877 and 1902, include blacksmith, tinsmith, machinist, contractor, builder, carpenter, painter, decorator, warehouseman, shipping clerk, bookkeeper, clerk, gravedigger, shoemaker, bartender, coachman, gardener, dry goods, grocer, musician, and writer. This job spectrum strongly implies that Germans were probably either directly or indirectly responsible for most of the initial residential 
construction, and perhaps also much of what limited commercialization occurred there. Vocations are not listed in city directories for many of the Anglos in the block or for H. Shapiro. An exception was the Anglo physician, Dr. W. L. Barker, who owned the property at 104 Wyoming in 1914.

\section{NCB 614}

NCB 614 is one of the seven blocks in the area which were originally platted as squares and have retained that shape to the present (Figure 6-7). It was bounded on the north by Wyoming Street, on the south by Dakota Street, on the east by Walnut Street and on the west by Plum (Hoefgen) Street. The surrounding
NCBs included 606 on the north, 607 to the northeast, 615 on the east, 622 to the southeast, 621 on the south, 620 to the southwest, 613 on the west, and 605 to the northwest. NCB 614 is designated on the Baker survey map as Alamo Iron Works Tract 6.

NCB 614 was initially purchased from the city by George T. Howard in 1850 . He sold the property to Oliver P. Temple in 1851, who then conveyed the block to Charles S. Todd in 1853. Todd established a power of attorney with William H. Young in 1868 and Young apparently subdivided the block into 12 lots at that time. During the residential phase of development, an unnamed alleyway extended east-west across the block and separated the northern half, which included Lots 1-6, from the southern half, which included Lots
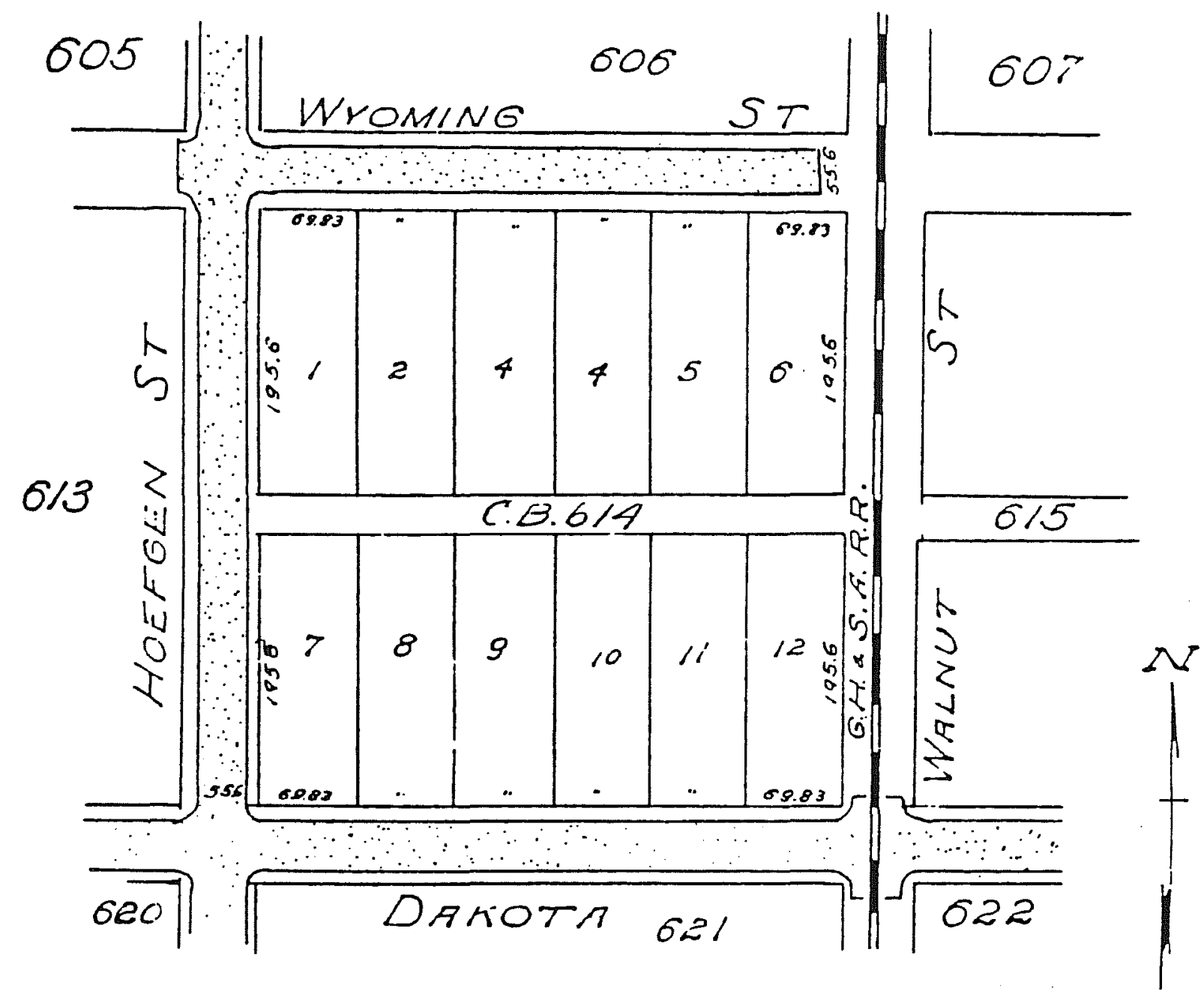

Figure 6-7. Plat of NCB 614, ca. 1910. S. A. Map Company. 
7-12. In 1870 Young sold nine of the lots to Enoch F. Deaton, Lots 11 and 12 to Hart and Susan Mussey, and the remaining Lot 6 to Mary M. Poor.

Koch's 1886 bird's-eye map (Figure 3-15) indicates there were probably no structures on the block when Young sold the lots in 1870. Apparently the first construction on the block began after Girolamo San Marco purchased Lot 1 and the western half of Lot 2 in 1900 . The remainder of the block was purchased by the Galveston, Harrisburg and San Antonio Railway Company in 1901 and subsequently became the site of the Southern Pacific Freight Depot (cf. Sanborn maps 1905 and 1911). The Valley Ditch ran down the west side of Walnut Street on the eastern edge of this block.

\section{NCB 615}

NCB 615 was also square and contained a bisecting east-west alley (Figure 6-8). It abutted Wyoming Street on the north, Dakota Street on the south, South Cherry Street on the east, and South Walnut Street on the west. It was surrounded by the following NCBs: 607 on the north, 608 to the northeast, 616 on the east, 623 to the southeast, 622 on the south, 621 to the southwest, 614 on the west, and 606 to the northwest. Apparently, it was never directly affected by the expansion of Alamo Iron Works since it is not assigned an Alamo Iron Works tract number on the Baker survey map.

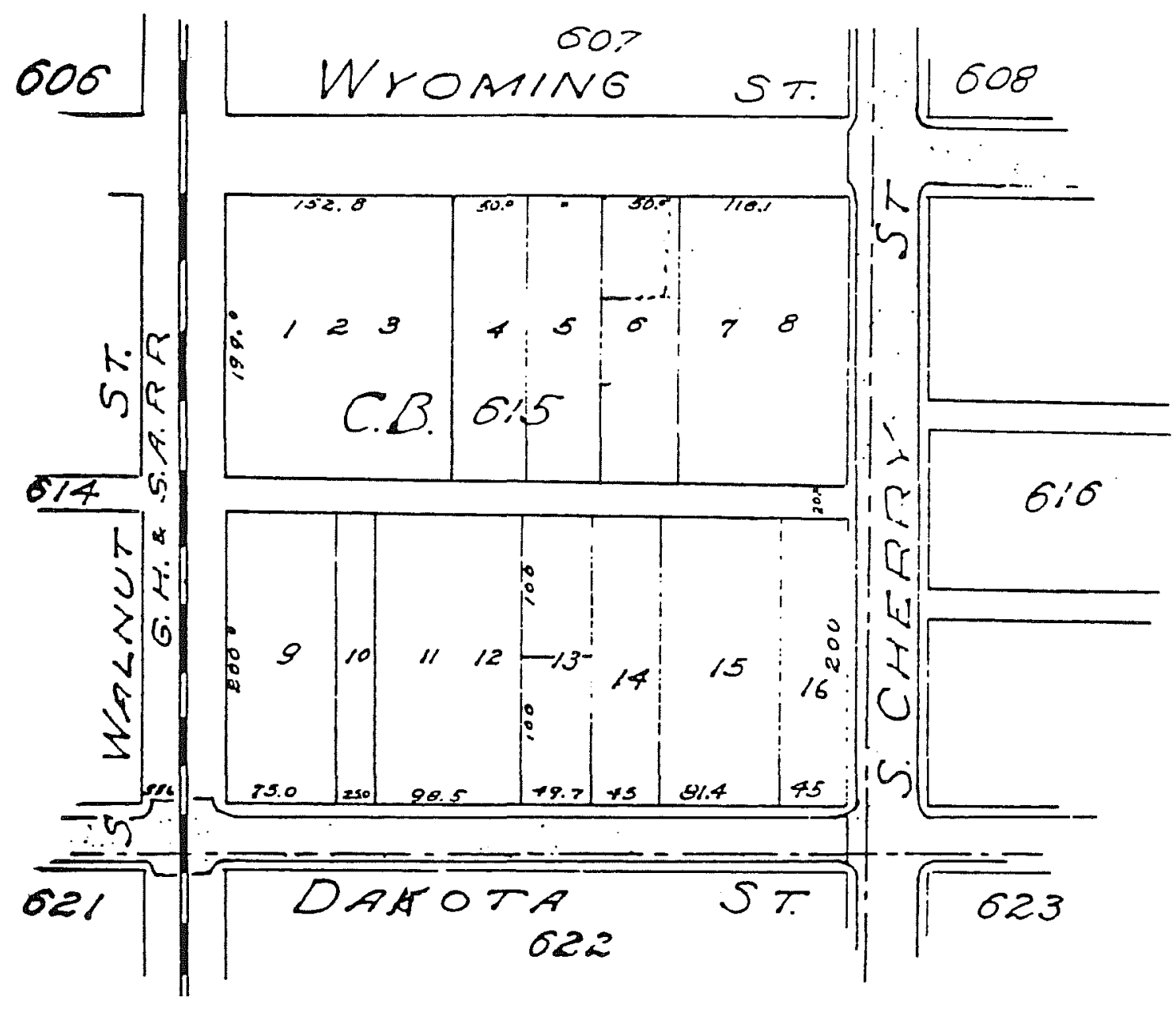

Figure 6-8. Plat of NCB 615, ca. 1910. S. A. Map Company. 
This block is one of the four purchased by James $M$. Devine in 1850 . Transaction records indicate that he sold it to James H. Kampmann in 1851. In 1853 Kampmann sold it to Christof Postert, who conveyed it to Peter Pauly in 1855. It appears that Kampmann, Postert, and Pauly were initial partners in a real estate venture for the purchase, holding, and/or development of the block with a fourth man, Louis Zork, who may have joined the venture in about 1864. A fifth individual, T. Templeman Vander Hoeven, may have been either a financier or partner in the venture. The existence of this real estate venture is implied generally by the relatively prominent socioeconomic status of the participants and specifically by transaction record entries just after the conveyance from Christof to Pauly; however, further research is needed to confirm that it indeed existed.

Pauly was a German-Texan architect, builder, and stonemason who lived in the home at 325 Dakota (Lots 14 and 15) near the southeast corner of the block. He built the home in 1855 and continued to reside there until his death in 1894. Sanborn maps from the early twentieth century indicate that the home was originally constructed of adobe, i.e., probably fairly soft, cut limestone or caliche blocks set in mortar and surfaced with plaster or stucco (SM 1905 and 1911). County death records contain the following information. Pauly was 84 and residing at 325 Dakota Street at the time of his death, was a widower, born in Germany, lived in Texas 45 years, and died April 4, 1894, of bronchitis. The attending physician was Amos Graves, and Pauly was buried in the German Catholic Cemetery. Transaction records indicate that Pauly was also substantially involved in the development of NCB 620 , as detailed below.

Several parcels of land involving single lots or combinations of several lots were sold in NCB 615 from ca. 1880 to 1891 . By 1905 the Sanborn map of the block shows a total of six free-standing dwellings there; by 1911 , this number had increased to 10 . With the exception of the Pauly home and the home built by Julian Czernecki in 1890 at 724 Wyoming (Lots 6, 7, and 8), all the dwellings in the block date to the post1900 period. Commercial development began when Otto Zirkel purchased Lots 1, 2, and 3 in the northwest comer of the block in 1907. He opened the Otto Zirkel Granite and Marble Works there in 1909. The business continued in operation under that name until sometime after 1952 (SM 1952).

In the early $1890 \mathrm{~s}$, Steven Margozevitz, Sr., purchased Lots 4 and 5 and he and his wife Mary built their home on Lot 4. At an unknown later date, Steven Margozevitz, Jr., built his home on Lot 5 . The following information on the Margozevitzes is from an oral interview with Agnes Mahula, granddaughter of Steven Margozevitz, Sr., conducted by Maria Watson Pfeiffer of E. L. Fly and Associates. Both Steven Margozevitz, Sr., and his wife Mary Czernecki Margozevitz were born in Poland, in 1843 and 1854, respectively. After marrying there, they immigrated to the United States and had 12 children, seven of whom lived to adulthood. Four of the boys opened the brass foundry on Lots 4 and 5 of NCB 615 in 1925. Steven, Sr., died in 1917, Mary in 1931.

The brass foundry is shown as Acme Brass Foundry on the 1952 Sanborn map of the block. It was apparently the only commercial structure besides the Otto Zirkel Granite and Marble Works in the block until the mid-twentieth century. The 1952 Sanborn map indicates that Lots 9-12 were converted to a foodprocessing plant with cold storage facilities. Also by that time, Lot 14 was occupied by the U. S. Heat Treating Co., which manufactured oil field equipment.

\section{NCB 620}

NCB 620 was originally a square block through which Pauly Alley (later Pablo Alley) extended east to west (Figure 6-9). It was bounded on the north by Dakota Street, on the south by Nevada Street, on the east by Plum Street, and on the west by Peach Street. Adjoining NCBs included 613 on the north, 614 to the northeast, 621 on the east, 628 to the southeast, 627 on the south, 705 to the southwest and west and also 704 to the west, and 612 to the northwest.

The block was first purchased from the citysimultaneously with NCBs 607,615 , and 622-late in 1850 by James M. Devine. Early in 1851, Devine sold NCB 620 to James H. Kampmann. Both Devine and Kampmann were prominent mid-nineteenth century San Antonians (see NCBs 605, 606, and 607). The entire block passed through a series of owners until 


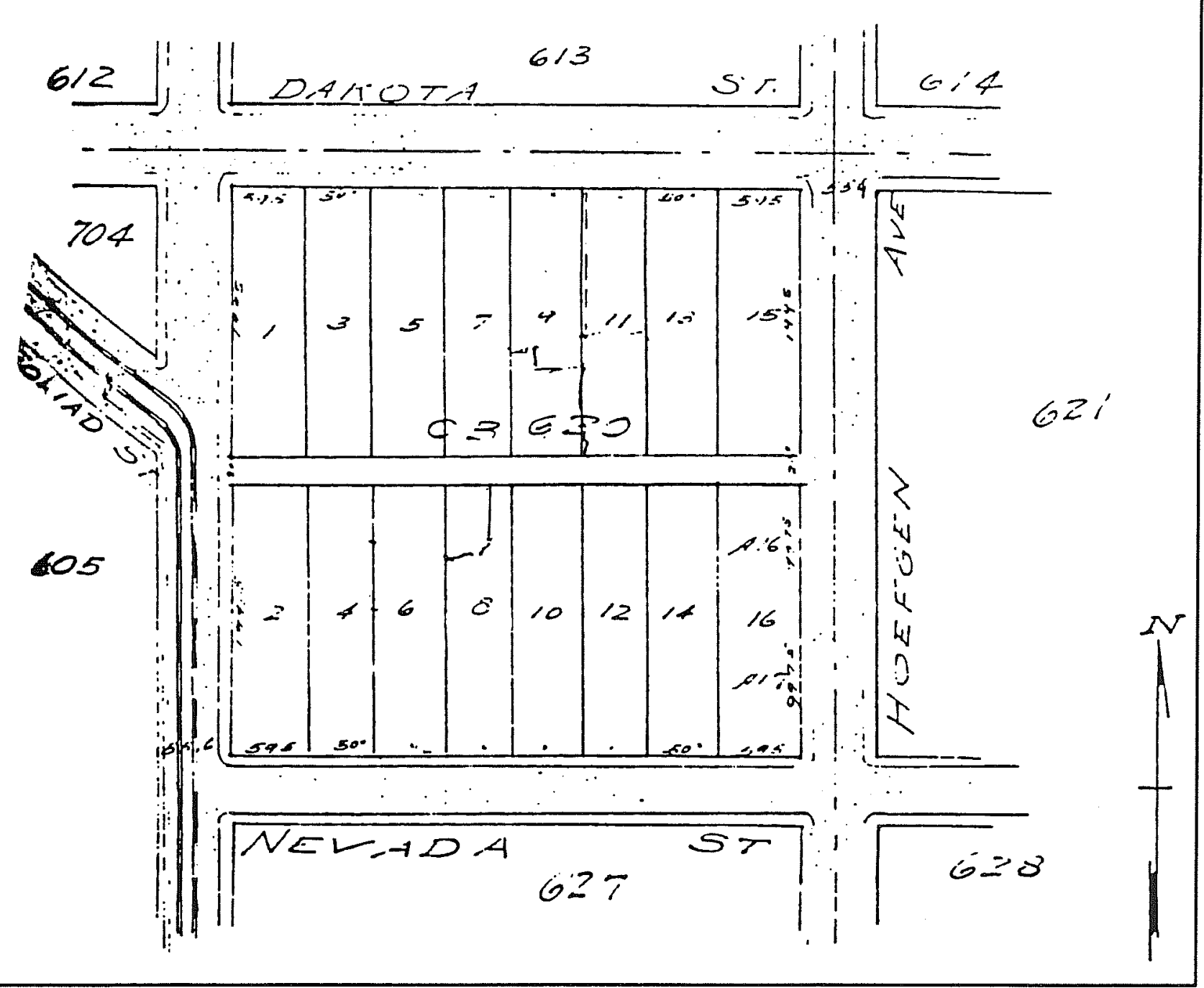

Figure 6-9. Plat of NCB 620, ca. 1910. S. A. Map Company.

Peter Pauly, a local architect and builder, purchased it in 1855 . Pauly held the block until 1877 , when he apparently went into partnership with John $M$. Tanguary, George Kalteyer, and Honore Grenet. This is evidenced by several entries in the Bexar Abstract and Title Company transaction records which first show the block being divided among the four men as trustees and later show "P. Pauly, et al." as grantor for individual lot sales.

Peter's son Henry was also an architect and builder. Henry was in partmership with John C. Dielman from about 1891 to 1895 . Their office was located on Lavaca Street. By 1895 the partnership had apparently dissolved. Dielmann continued to operate from the Lavaca Street office, but by that time the younger
Pauly had his office at 102 Peach Street at the corner of Goliad Road. Henry Pauly acquired Lots 1, 3, and 5 of NCB 620 in 1882, and purchased all of the even numbered Lots 2-16 (which comprised the south half of the block) in 1883. He lived on the block in the home at 108 Dakota Street from about 1891 until his death in 1902 . City death records indicate that he was age 51 at the time of death ca. 1903, married, born in Texas, a lifelong resident of San Antonio, and that he died of tuberculosis and diabetes. Dr. Amos Graves was the attending physician and Pauly was buried in St. Joseph's Cemetery. His widow Amalie married George F. Littler later in 1903 and the Littlers apparently continued to occupy the home at 108 Dakota Street (Lots 1, 3, 5, and 7) until an unknown date after 1931. 
Henry Pauly probably built the home on Lot 12 for the mason August H. Roatzsch and his wife Marie in about 1883. August Roatzsch died in 1895 and, by 1901, the widow Roatzsch sold the homestead at 123 Nevada to Arthur Griesenbeck (SM 1905). Griesenbeck's vocational history is noteworthy. $\mathrm{He}$ is listed in city directories as having had the following occupations: butcher (1877), laborer (1883), teamster (1892), carpenter (1897), and dry goods clerk (1901).

Lot 11 on Pauly Alley originally contained a wood frame home that was built by the firm of Gauss and Johns for Henry and Ida Koch in 1886. In 1906 the property was purchased by Mrs. Alma Hehn, wife of Peter, a feed dealer. They apparently constructed the two auxiliary buildings at 139 and 141 Pauly in 1915 as rental units.

The home shown on the 1905 Sanborn map at 127 Nevada Street (Lot 14) was built ca. 1886 for Paul Johns and his wife Terese (SM 1905). Martin and Schryver, a local building supply firm located at the corner of North 5th and Walnut Streets, took a mechanics lien on the property during construction. Johns, whose name is spelled "Yahns" in the transaction record for the purchase of Lot 14, was a carpenter for Southern Pacific Railroad from the late 1880s until about 1902 (CDs 1887, 1892, 1897, and 1901). No death records were located on Johns and apparently he or his family continued to own the property at 127 Nevada Street well into the twentieth century. Transaction records for NCB 620 available at the time of this writing continue through May 1931 and do not contain any conveyance or probate entries for Lot 14 after the release of Martin and Schryver's lien in November of 1886.

Commercial development of NCB 620 occurred in the mid-twentieth century and was confined to the northern half of the block. A "motor freight station" with loading warehouse and office was built on Lots 13 and 15 at the corner of Dakota Street and Hoefgen Avenue. This became the site of Allied Electric Company (still operating there as of this writing) sometime after the early 1950s (SM 1952). There were also commercial warehouses in the northwestern portion of the block which were apparently built during this same period. They were removed when IH-37 was built. Since they date from a relatively late period in the area's historical sequence, and since the area where they once stood had been completely covered by the highway, their histories were not investigated. No other commercial developments are known to have occurred in the block and it was never altered by the expansion of Alamo Iron Works. At the time of this writing there were about a half-dozen single-family residential dwellings, including the Griesenbeck and Johns homes, still standing in roughly the southeastern quadrant of the block.

\section{NCB 621}

This block was originally square and was bounded on the north and south by Dakota and Nevada streets, respectively, and ended at South Walnut Street on the east and at Plum (Hoefgen) Street on the west. Surrounding blocks included 614 on the north, 615 to the northeast, 622 on the east, 629 to the southeast, 628 on the south, 627 to the southeast, 620 on the west, and 613 to the northwest. When residential subdivision of the block began about 1858, Grape Street was added as a north-south throughway, bisecting the block into rectangular halves. The block has retained this basic configuration (Figure 6-10) to the present. The northwest quadrant of the block is designated on the Baker survey map as Alamo Iron Works Tract 9.

NCB 621 was first purchased from the city of San Antonio in 1851 by Frank Lafitte Paschal. He conveyed the property to Robert Eagar the following year. The block was subdivided into 16 lots ca. 1858, and eight of the lots were transferred in two- and three-lot parcels the same year. The lots continued to change hands until 1885 , when the western portion of the block was replatted into smaller units facing Plum Street. The houses on those lots appear to have been constructed between 1888 and 1892 . The construction dates for the two structures on Lots 14 and 15 (facing on Nevada) have not yet been determined.

Commercial development in the block began ca. 1913 with the construction of the General Hotel Supply Company at the corner of Dakota Street and the Southern Pacific Railroad tracks. The company was expanded in 1938 and, by 1952, occupied the entire eastern half of the block, i.e., the section between Grape Street and the railroad tracks (SM 1952). By 1952 the company consisted of a large main building, and a sizeable parking area. Its auxiliary structures 


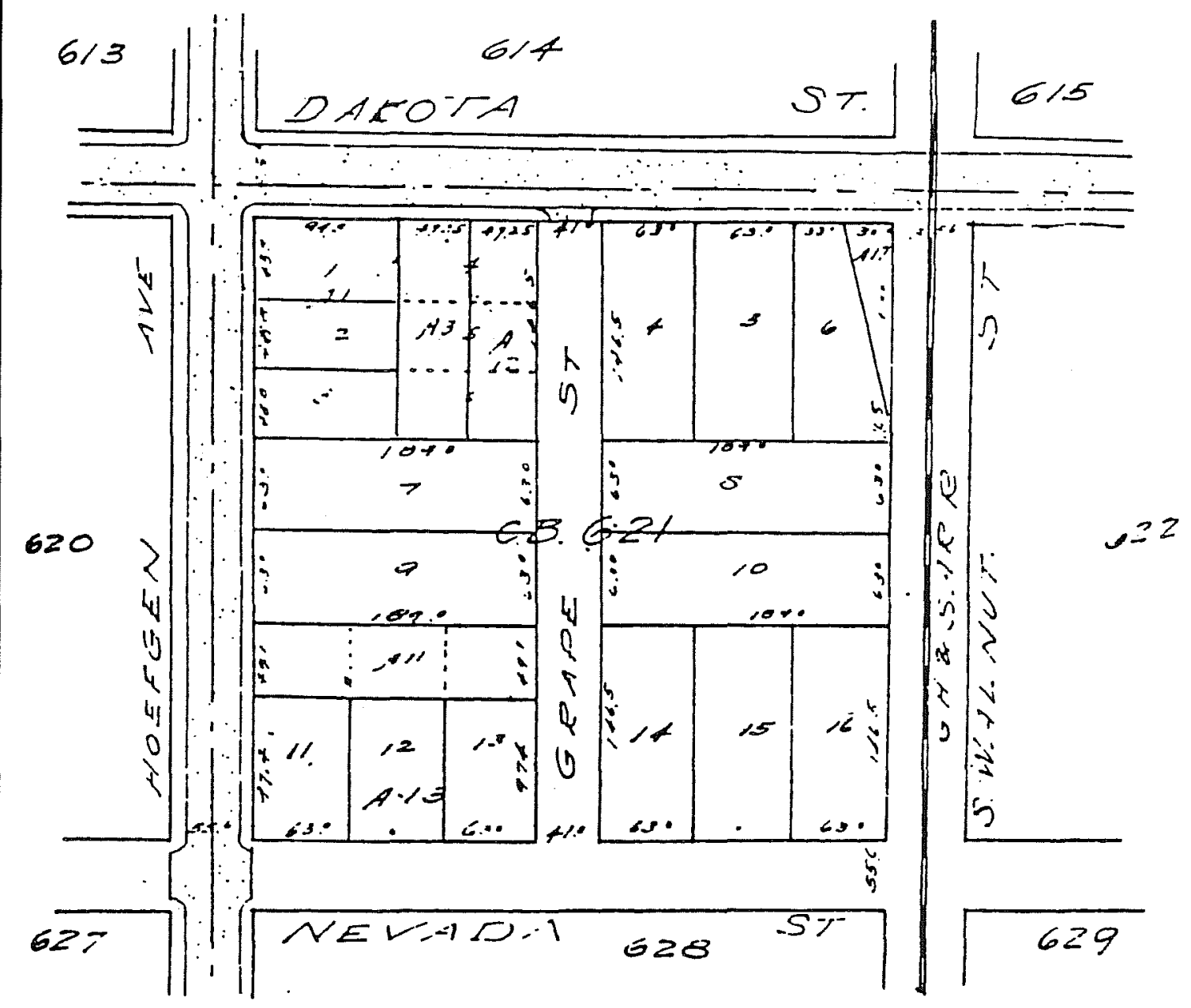

Figure 6-10. Plat of NCB 621, ca. 1910. S. A. Map Company.

included a fixture manufacturing shop, a machine shop, a sheet-metal works area, loading area, and lunch room. Also, at a time and for reasons as yet undetermined, the residence at 210 Dakota Street was converted to an office and warehouse.

There is evidence that a ditch of some sort entered approximately at the midline on the north and exited about the middle of the block on the east. Its path is shown clearly on a plat map on file at the City Engineer's Office entitled "Subdivision of Blocks 30 \& 36 on Goliad Street" which was made for Bernard J. Mauermann and bears the date November 17, 1877. The map shows that the ditch extended eastward completely across the middle of NCB 622 to intersect with the portion of the Valley Ditch which ran south along South Cherry Street. Unfortunately, this map does not cover the area north of the northern edge of NCBs 621 and 622 at South 4th Street (later Dakota Street), and no other maps have been discovered which show any other portions of the ditch.

\section{NCB 622}

When first platted, this block was square. Dakota, Nevada, South Cherry, and South Walnut streets bounded the block on the north, south, east, and west, respectively. Surrounding NCBs included 614 on the north, 615 to the northeast, 623 on the east, 630 to the 
southeast, 629 on the south, 628 to the southwest, 621 on the west, and 613 to the northwest. The basic configuration and boundaries of the block (Figure 6-11) have remained the same to the present, and no interior streets or other throughways have been added. There is as yet no indication that Alamo Iron Works ever expanded into the block.

The block was first purchased from the city by James M. Devine in 1850 . Devine sold it to Casper Herber in September 1851. Herber then sold it less than a month later to Christian Schleyer, who began selling small parcels in 1855. Gottlieb Glaeser, who bought Lots 7 and 8 in the south half of the block in that year, was the first purchaser during the residential subdivision phase of development. Between them, Gottlieb and Ehrenfried (relationship to Gottlieb undetermined) Glaeser had purchased all 12 lots in the block by 1856 .

The lot numbering system for the block is unusual. The block was split into north and south halves. From the early $1850 \mathrm{~s}$ through at least the mid-1940s, the transaction records reflect Lots 1-7 for the north half and Lots 6-10 for the south half. The total number of lots was thus 12 , with each half having a Lot 6 and a Lot 7. The reason for this arrangement was not discovered. By about 1910, several of the original 12 lots had been further subdivided, resulting in a total of between 17 and 20 lots in the block, depending upon how the divisions are interpreted.

By 1904 about 16 free-standing dwellings were present in the block (SM 1904). Those which were designated as 305 and 325 Nevada were apparently midnineteenth century "adobes." Only two additional dwellings were built by 1911 (SM 1911). No commercial structures are shown at that time.

From the mid-1850s through the turn of the twentieth century, surnames associated with residential parcels of land in the block were primarily German: Gembler (southern half of the block: Lot 6, 1871); Grimsinger (southern half of the block: Lot 6, 1875, and western two-thirds: Lot 7, 1887); Hartmann (south half of the block: Lot 6, 1872); Perner (north half of the block: Lots 3 and eastern half of Lot 6, 1867); Hassar (Lot 4 and western half of Lot 5, 1874); Schroeder (Lot 6, 1875); Hildebrandt (southern half of the block: Lot 6 , 1876); Stucke (southern half of the block: Lot 6, 1876); Huppertz (Lot 10, 1884), Fusell (Lot 4, 1886);
Steves (Lot 4, 1886); Yahns (later shown as Johns; Lot 2, 1889); Poessman (northern half of the block: Lots 6 and 7, 1889); Kossfeld (Lots 9 and 10, 1866); Kalteyer (southern half of the block: Lots 7, 8, and 9; 1892); Heubaum (southern half of the block: Lot 6, 1892), Otto (Lot 9, 1893); Stappenback (Lots 8 and 9; 1893); Staffel (southern half of the block: Lot 6, 1898); Klar (southern half of the block: Lot 6, 1899); Heppenbeck (Lots 8 and 9, 1899); and Dullnig (southern half of the block: Lots 7, 8, and 9; 1900). The ownership and occupancy of the block continued to be dominated by Germans well into the first quarter of the twentieth century; however, both Anglos and Hispanics appear with greater frequency after 1900.

By the early 1950s, a Southwestern Bell Telephone Company warehouse, parking garage, and materials yard occupied the entire western edge of the block along the Southern Pacific Railroad tracks (SM 1952). Also by this time, the outbuilding to the rear of the residence at 320 or 324 (1952 Sanborn shows both numbers) Dakota was an auto painting and upholstering shop. Apparently, no other commercial development occurred in the block.

\section{NCB 627}

Information gathered and examined to date indicates that this block has been of the basically trapezoidal shape shown in Figure 6-12 for a large part of its history. It was originally bounded on the north by Nevada Street, on the south by Goliad Road, on the east by Plum (Hoefgen) Street, and on the west by Peach Street. Adjacent NCBs included 620 on the north, 621 to the northeast, 628 on the east, 635 to the southeast, and 105 on the west and northwest. In Spanish colonial times, Goliad Road was the Camino La Bahia, one of the royal highways or caminos reales that connected San Antonio de Bexar with various points in Texas and Mexico. It is reputed to be one of the oldest roads in Texas east of the San Antonio River and may date from 1740 or even earlier (Cox 1990:11).

In 1967 the western end of NCB 627 was slightly truncated by the construction of IH-37. That same year Victoria Street was widened and incorporated into the extension of Durango Boulevard, and the new street and right-of-way took a narrow strip off the southern 


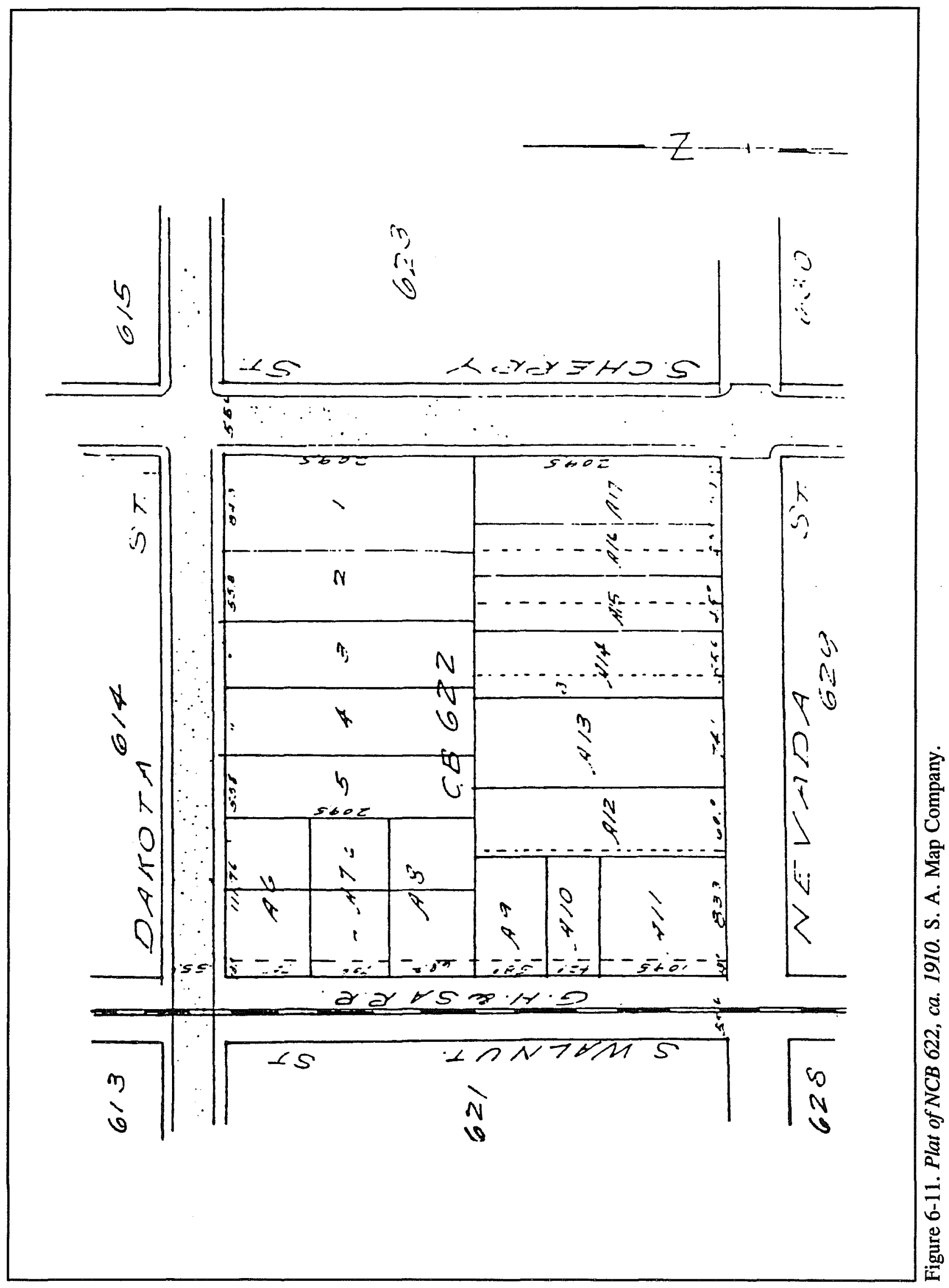




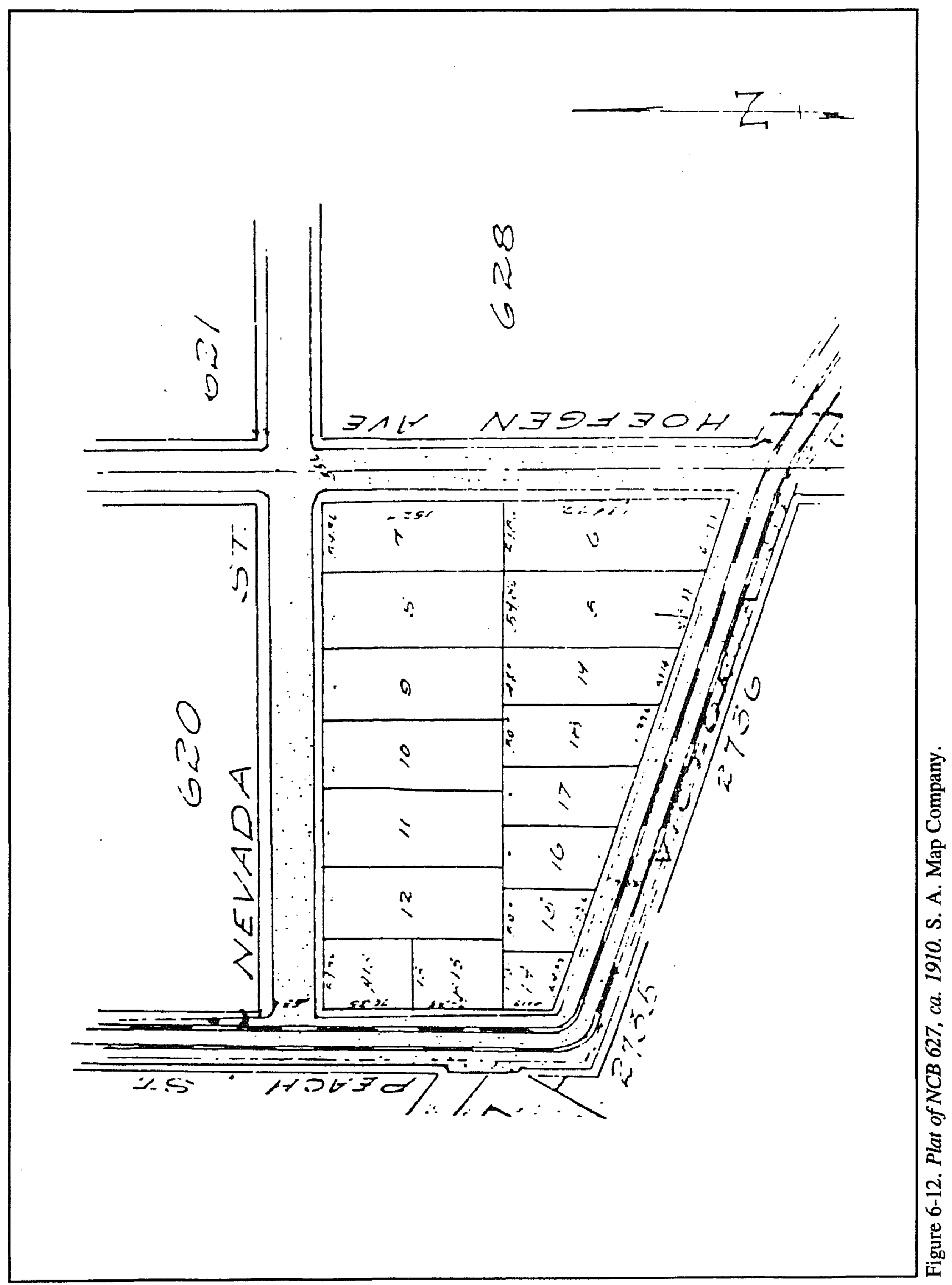


end of the block. No known additional internal streets or throughways have been added to the block.

The block was first purchased from the city of San Antonio-simultaneously with NCBs 629 and 636-by Nemenico de la Zerda in 1850. De la Zerda held NCB 622 until 1856 and then sold it to Louis Demazieres (first entered in the transaction records as $L$. D'Emazieres). Demazieres, who lived on Martinez Street at that time, probably built the home at 102 Nebraska (NCB 636, Lot 4) for one of his five siblings. Waynne Cox (personal communication 1992) believes it was built for the eldest of Demazieres's four sisters, Sophia.

Louis Demazieres died in France in 1862, apparently leaving undivided interests in NCBs 627 and 636 to his brother Charles and sisters Sophia, Celine, and Constant. Charles died in 1865, and Sophia sold both of the blocks to Bernard J. Mauermann in 1874. The latter developed the blocks residentially and sold small parcels in NCB 627 to urban homesteaders during the period from 1874 to about 1890 . Various records indicate the construction dates of homes located at the following addresses on the 1905 Sanborn map: 128 Nevada (1899), 409 Plum (1899), 411 Plum (1899), 413 Plum (1899), and 417 Plum (1896). In 1905 about 14 single-family dwellings were on the block. In 1906 Maumermann sold Lots 1, 2, 3, and 4 to George Roe and Lewis Ulrich and, in 1908, Roe and Ulrich replatted them into Lots 14-19. Between 1909 and 1915, these new lots all sold in small parcels for residential development. Also, in 1916, Lot 13 was replatted into two equal-sized parcels.

The 1905 Sanborn map indicates a store on Lot 5 (along Victoria Street, number not shown), a second and comparatively much larger store on Lot 6 at 427 Plum Street, and a third store with an adjacent saloon on Lot A13 at 300 Peach Street and 104 Nevada Street, respectively. By 1952 there was an auto paint shop at the rear of Lot 5 at 723 Victoria Street, a store at the front of the lot at 725 Victoria, an adjacent dry cleaners at 727 Victoria, a second store at $7271 / 2$ Victoria, a filling station on the south end of Lot 6 at 627 Hoefgen (corner with Victoria), and an auto repair shop near the middle of Lot 6 at 641 Hoefgen (SM 1952).

\section{NCB 628}

NCB 628 has been essentially trapezoidal shaped from its formation to the present (Figure 6-13). It was initially bounded on the north, south, east, and west by Nevada Street, Goliad Road, South Walnut Street, and Plum (Hoefgen) Street, respectively. The following NCBs were adjacent to 628: 621 on the north, 622 to the northeast, 629 and 636 to the east, 635 on the south, 634 to the southwest, 627 on the west, and 620 to the northwest.

NCB 628 was first purchased from the city by Emily and Oscar Brackett in 1851. The Bracketts sold the block to James Henderson in 1852. Henderson died in 1853 and on August 11, 1860, Emily Brackett reacquired the block via an administrator's deed issued by County Clerk Samuel S. Smith. For unknown reasons, she transferred it on that same date to Gustavus Theisen. Between 1860 and 1874, the entire block was transferred through several intermediate owners to the firm of Adams and Wickes, which began residential development there in about 1874 . The block was subdivided into 21 lots around that time.

In 1886 C. H. and Jane Dorsey purchased Lot 15 on the corner of Plum Street and Goliad Road. They may have had one dwelling, or possibly two, at that time. In 1888 Albert Wiese purchased Lot 1 (on the southeast corner of Plum and Nevada streets). By 1891 he erected the store and saloon at 402 Plum Street. The latter was probably the first private commercial entity ever in the block, the only other being a restaurant shown on the 1952 Sanborn map at 807 Victoria Street. Wiese also built his residence attached to the rear of the store. In 1889 Robert Inman purchased Lot 16, to the east of the Dorseys, and constructed his residence there shortly afterward. In 1905 there were 11 dwellings on the block, all on the western side (SM 1905). Transaction records indicate that all these residences were built between 1896 and 1901.

The later history of Wiese's store is as follows. Wiese apparently continuously operated the store until about 1936. It was closed and vacant until about 1937 , when Nicolas Garcia-Garza (also known by the surname Garza-Garcia) purchased the north 88 feet of Lot 1 and reopened it as a grocery store. The Garcia-Garza family continued to operate the store there until just a 


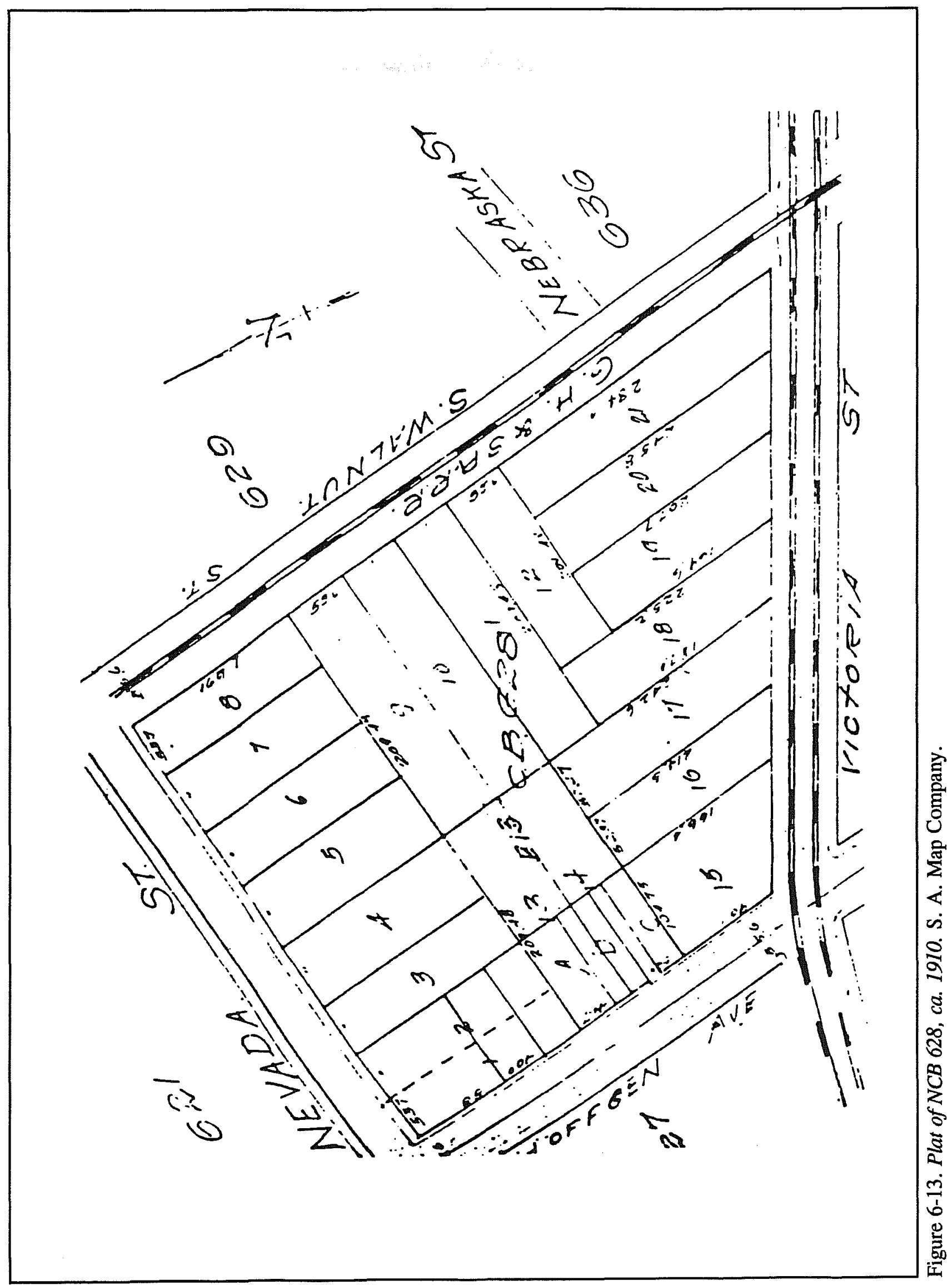


few months prior to the start of the project (Waynne Cox, personal communication 1990). In 1950 the property and store were transferred to "Alfonso J. and Mary R. Garza" (Bexar Abstract Company transaction records, NCB 628, sheet 2, lines 58-61).

By 1911 the southwest portion of the block, including Lots $11,12,18,19,20$, and 21 , had been converted to the City Asphalt Plant and another five residences had been added (SM 1911). Physical components of the asphalt plant shown on that year's Sanborn map include an asphalt machine and wagon shed. By 1952 the asphalt plant had expanded both physically and functionally (SM 1952). It had been renamed the Department of Public Works City Material Yard, and Lots 5-10, 17 and portions of 13 and 14 had been incorporated into the unit. The home on the latter lot had been converted to an office (facing on Victoria Street). Other physical components then included a second office near the railroad track along Nevada Street, a machine shop, an auto repair shop, two buildings labelled "BL SM" (blacksmith shops), a stock room, a paint shop, municipal garages, a "truck shed," earthen loading ramps, a large materials storage yard, and a large, open-air truck parking area. Thus, a major portion of NCB 628 has remained city of San Antonio property from the formation of the block to the time of this writing. Other than the few described above, there were apparently no nonmunicipal commercial or industrial developments in the block.

Probably because development in the block started comparatively late, in the $1890 \mathrm{~s}$, the majority of occupants of the block during the early residential phase were Anglos. Minorities consisted of a few Poles and blacks, one probable Frenchman, and one Irishman. Also, some Hispanics began to move into the block in the 1940s and 1950s. It was not determined which ethnic group, if any, was primarily responsible for the structural developments in the block.

\section{NCB 629}

This is the southernmost of the seven blocks which were first platted as squares and have retained their original shape to the present. It was initially bounded on the north by Nevada Street, on the south by Nebraska Street, on the east by South Cherry Street, and on the west by South Walnut Street. It had the following surrounding NCBs: 622 on the north, 623 to the northeast, 630 on the east, 637 to the southeast, 636 on the south, 628 to the southwest and west, and 621 to the northwest.

This is one of three blocks in the Alamodome impact area first purchased from the city by Nemenico de la Zerda in October 1850. The others were 627 and 636. De la Zerda sold 629 to Adolphus Schloemann and August Nette in 1853. Schloemann and Nette retained the property in an unimproved state until they transferred it to Robert and Sarah Eagar in June 1871, and later that year residential-sized parcels were sold for the first time. Eighteen primary lots were platted, and by the end of 1872, all but Lot 5 had been sold. Most of these sales were in multiple-lot parcels to real estate investors. Although several San Antonians who were socially or politically prominent during this period are connected with various lot transfers, including Thomas J. Devine (Lots 6 and 7, 1872) and William L. Menger (Lots 4, 6, and 7, 1889), it is unclear at this point who, if anyone, controlled the residential development in the block.

Such development proceeded slowly into the early part of the twentieth century. By 1905 only five residences were on the block, but by 1911 about 13 dwellings with their attendant outbuildings and one store were present (SM 1905, 1911). Apparently built about 1909 by William L. Menger, the store was located on the 1911 Sanborn map on Lot 7 at the corner of Nevada and South Cherry streets. Its exact purpose was not determined.

In 1914 the Galveston, Harrisburg and San Antonio Railway purchased the west $17 \mathrm{ft}$ of Lot 8 , and the west halves of Lots 10 and 12, apparently for use as a general loading area. In 1928 Magnolia Gas Products Company purchased Lots 10,12,13, and half of Lot 14. Transaction records indicate that in that same year, the gas company entered into an agreement with the railroad regarding Lots 8,10 , and 12 . By 1952, Lots 10,12 , and 13 on the railroad track at Nebraska Street are shown as occupied by the Air Reduction Magnolia Company, which engaged in welding gas manufacturing and storage (SM 1952). The company's physical components at that time included an office with an attached loading shed and warehouse (Lot 12), a detached gas holding tank (Lot 13), and a small detached shed (Lot 10). 
Also by 1952 , City Water Board supply yard facilities occupied the northern half of the block, including all of Lots $1-7,9$, and 11 . The city had purchased these lots back from various individuals, in separate parcels, between 1937 and 1950. Some of the physical components in place by 1952 included an office and attached supply warehouse on the corner of Nevada and the railroad track (Lots 1 and 2), and an auto repair shop along Nevada near the center of the north side of the block (Lots 3, 4, 5, and 6). At the rear of this auto shop was a detached, 36-car garage. All of the latter were built in 1949 (SM 1952). A larger office was added ca. 1952 at the corner of Nevada and South Cherry streets (Lot 7). A small shop building is also shown on the Water Board's property to the rear of Lots 9 and 11 near the geographic center of the block, and the entire complex was enclosed by steel (probably chain-link) fencing. Although some of these components were undoubtedly altered over the intervening years, the Water Board facility continued to occupy these premises until nearly the time of this writing. No other nonresidential developments are known at this time to have occurred in the block.

\section{NCB 636}

NCB 636 extends further south than any of the other blocks in the Alamodome impact area. It is one of five blocks in the area which are presently trapezoidal in shape. This shape for NCB 636 and also for several other blocks in the immediate area resulted from the northwest to southeast trend of Goliad Road, which adjoins those blocks. Also, the size, and to a lesser extent the shape of NCB 636, have been substantially altered by the subsequent lateral expansion of Goliad Road. The throughway which later became Runge Street was added to the block ca. 1918 by developer Bernard J. Mauermann to facilitate residential subdivision. It was officially adopted as a city street in 1924. It is L-shaped, with a long leg running north from Goliad Road and a short leg running west from South Cherry Street. It separates approximately the southeast one-fifth from the main portion of the block.

The entire block was purchased from the city in 1850 by Nemenico de la Zerda. The property passed through several hands until 1874 , when it was purchased by Bernard J. Mauermann. That same year, he subdivided the block into 18 individual lots. Only a few of those lots were sold before 1890 . Most of the primary lots were sold individually to urban homesteaders between then and 1905. Lots 10-15 passed as a unit through the Mauermann family until 1918, when they were acquired and replatted by Gus B. Mauermann. Consequently, almost all the structures in the island of land to the south and east of Runge Street, including about a dozen homes, were built in 1918. An exception was the home at 719 Cherry Street built in 1923.

By 1904 nine free-standing homes and their associated outbuildings were on the block (SM 1904). Most of them were clustered in the northern half of the block along Nebraska Street and Walnut Street (the railroad track). With the exception of the 1856 home shown on the 1904 Sanborn map at 102 Nebraska Street (Lot 5, corner Nebraska Street and the railroad track), which was built by Louis Demazieres, all of these homes were probably built between 1890 and 1913. By 1911 two more dwellings were shown on the Sanborn map, but there were no commercial structures in the block at that time. In addition to Lots $10-15$, which were being held in the Mauermann family, Lots 1,17 , and 18 remained unimproved.

William Jonas had purchased the latter three lots from Bernard Mauermann in 1910. They passed through several intervening ownerships until they were purchased by Thomas E. Barnes in 1924. Barnes opened a lumber sales yard there about 1928. By 1952 the Sanborn map shows the following structures on the Barnes property: two stores, two small restaurants, and an auto repair shop along Victoria Street; a paper and printing warehouse; and the T. J. Barnes, Jr., Lumber Yard. The store on the corner of Runge and Victoria streets is the largest of the two and may have been the lumber yard sales and showroom. The lumber yard also included five large lumber sheds and several modest-sized warehouses. Another structure shown at that time is a gasoline filling station at the corner of Victoria and South Cherry streets at the extreme southern end of the block. No other commercial developments are known at this time to have occurred in NCB 636.

Because the block developed comparatively late in the area's historical sequence, the ethnic composition is more mixed than in the other blocks considered here. Thus, it is probably not possible to accurately attribute 
structural development primarily to any particular group, and no attempt is made to so do here.

\section{NCB 679}

Although this block was platted for residential development (Figure 6-14), apparently none ever occurred. The whole block apparently remained vacant until ca. 1903, when the railroad built its passenger depot there. The depot was a nucleus for subsequent commercial development in the immediately surrounding blocks.

\section{NCB 681}

Only about half of this block (Figure 6-15) is within the Alamodome impact area. Although the block was platted into 21 residential-sized tracts when it was first formed in the mid-nineteenth century, most of the half in question was never improved prior to being purchased by the railroad ca. 1901 for a rail spur site. Perhaps the only development in the block which is historically important was the complex at $\mathbf{3 3 3}$ and $\mathbf{3 3 6}$ Lafitte, the homestead of Herman R. and Anna Geyer. Herman Geyer, a blacksmith, probably constructed the two-story frame home at 333 Lafitte in 1890 . The onestory structure at 336 Lafitte was apparently destroyed by the extension of Hoefgen Avenue. Since there are no other historically significant development sites in the block, it is not further examined here. The Baker survey map shows some of the relevant portion of NCB 681 at the southwest corner of Gonzales Street and Hoefgen Avenue. Although a tract at that location has the designation "A.I.W." (for Alamo Iron Works), no tract number is shown there.

\section{NCB 682}

Only a small portion of this block was situated within the study area. After some alterations, NCB 682 was located toward what was originally its eastern end near the corner of Lafitte and Santa Clara streets, and included all or portions of three of its eight primary lots: 6,7 , and 8 . The only developments occurring in this area of the block prior to very recent times included three or four free-standing dwellings and one store at the corner of Santa Clara and Lafitte streets.
These were apparently all constructed in the latenineteenth/early twentieth centuries. Alamo Iron Works purchased the northern halves of Lots 7 and 8 in about 1923. By 1952 the Iron Works had a machinery storage yard and warehouse there (SM 1952). Since no other developments are known to have occurred in this area of the block, and since the remainder of the block is outside of the study area, no further details are provided here concerning NCB 682.

\section{Acknowledgments}

Assistance from the following persons and institutions during the research for and preparation of this report is hereby gratefully acknowledged: (1) Anne A. Fox, I. Waynne Cox, Barbara Meissner, and the administrative, editorial, and secretarial staff of the Center for Archaeological Research, The University of Texas at San Antonio; (2) Donny Dennis and Jim Heath of the Mossrock Drive office of Stewart Title Company in San Antonio; and (3) Bexar County archivist John Ogden Leal. 


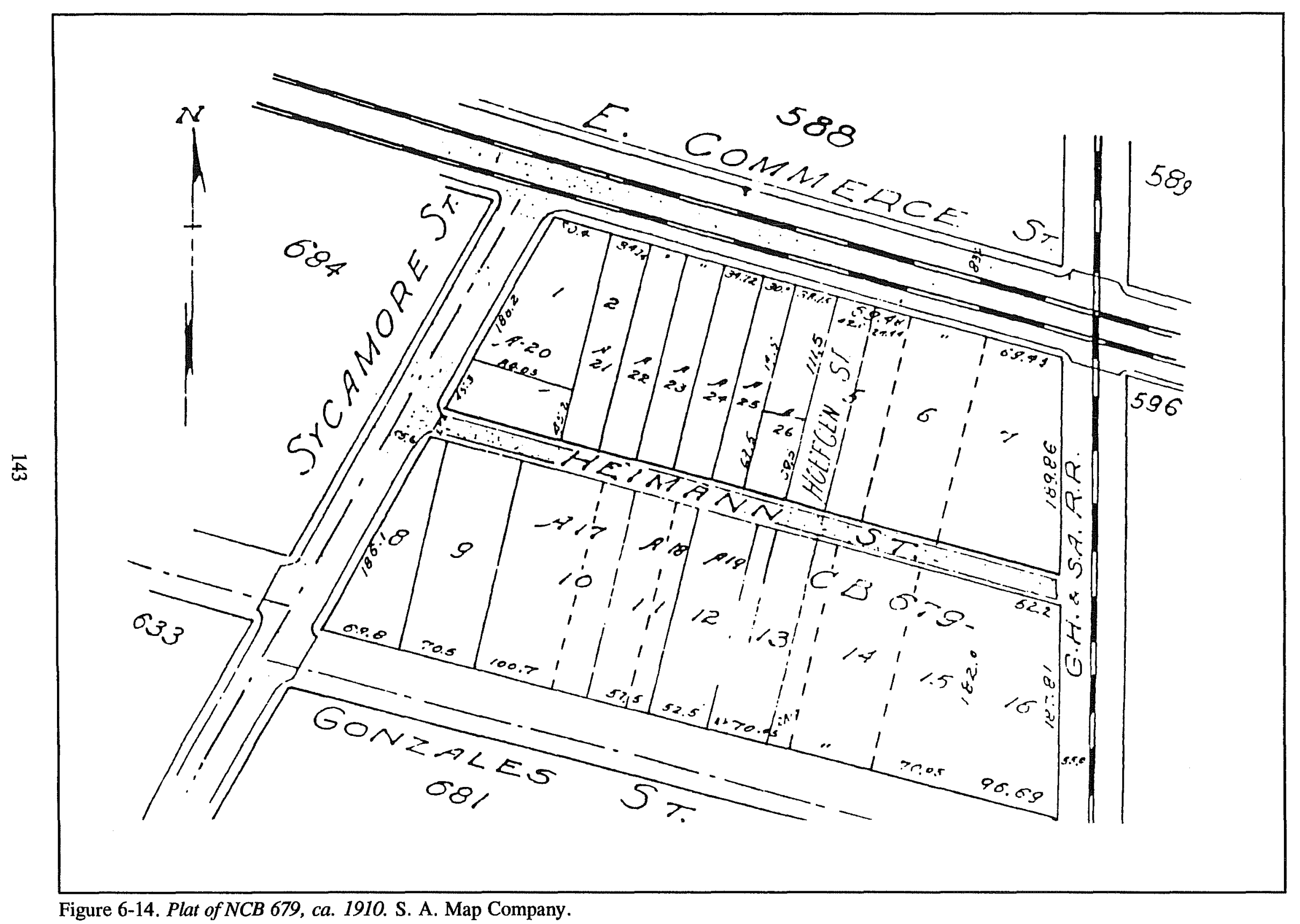




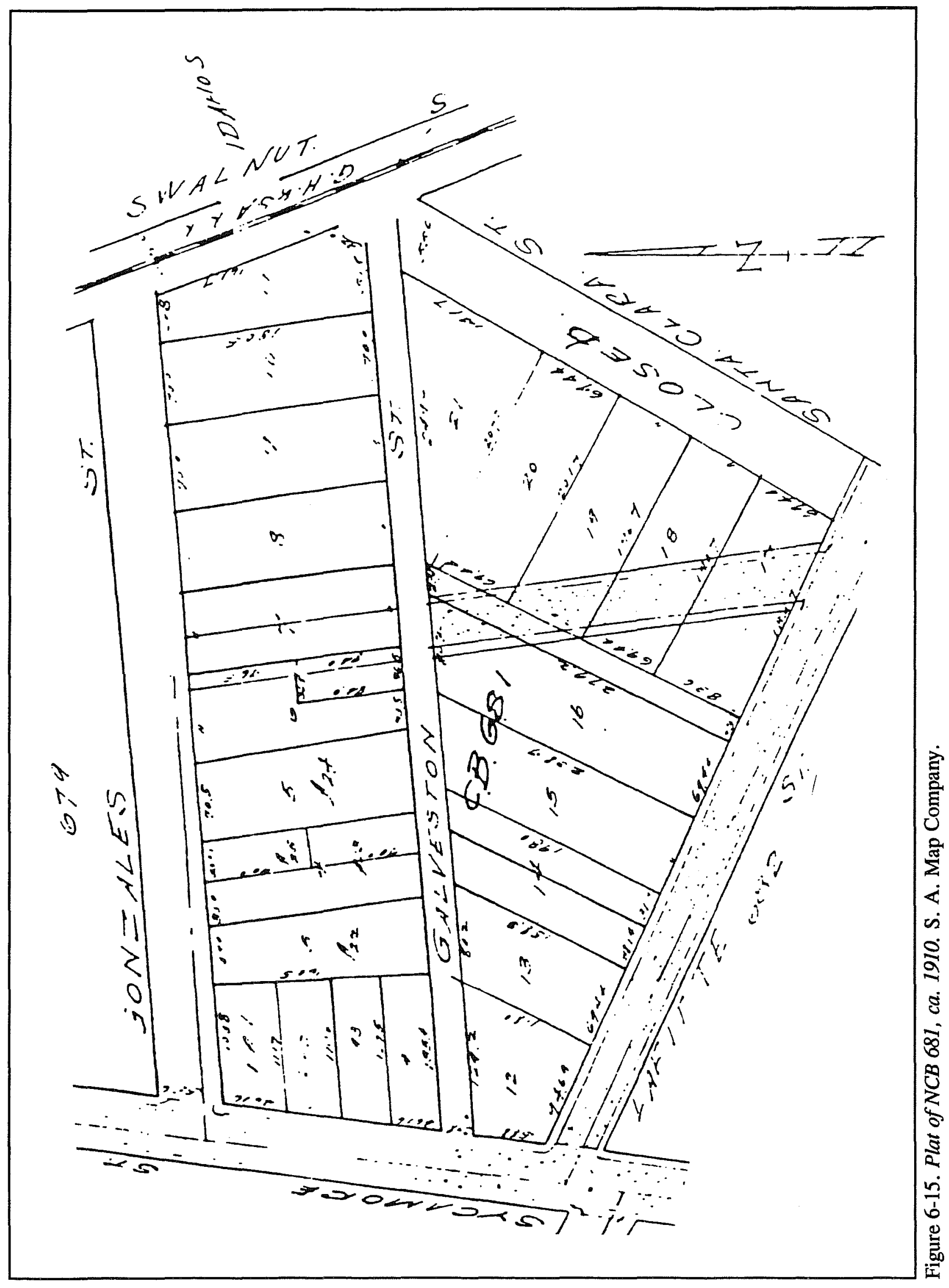




\section{References Cited}

Barnes, C. M.

1910 Combats and Conquests of Immortal Heroes: Sung in Song and Told in Story. Guessaz and Ferlet, San Antonio.

Cox, I. W.

1990 Field Survey and Archival Research for the Rosillo Creek Battleground Area, Southeast San Antonio. Archaeological Survey Report, No. 177. Center for Archaeological Research. The University of Texas at San Antonio.

Fehrenbach, T. R.

1978 The San Antonio Story. Continental Heritage, Tulsa.

Land and Thompson

1885 Historical and Descriptive Review of the Industries of San Antonio, 1885. Reprinted by Norman Brock, San Antonio, 1977.

San Antonio Light $[S A L]$

1899 Mortuary. November 8.

1953 Alamo Iron Works in 75th Year. May 24.

Steinfeldt, C.

1978 San Antonio Was: Seen through a Magic Lantern, Views from the Slide Collection of Albert Steves, Sr. San Antonio Museum Association, San Antonio. 


\section{Chapter 7 \\ Summary}

\section{Kevin J. Gross and Anne A. Fox}

\section{Development of Strategy for the Research}

The public tends to consider excavation as the most important part of an archaeological project. However, nothing could be further from the truth. The main objective of an excavation is to increase our knowledge of how people lived in the past-what sorts of shelter they sought, what they ate and wore, how they conducted their everyday lives. In addition, we do our best to fit the inhabitants of archaeological sites into the setting of their times, often in the process recovering details that were never recorded. Despite the many hundreds of books and articles published about the history of San Antonio, whole sections of its history have gone unnoted and are nearly forgotten.

One of the goals of the Alamodome Project has been to reach back into the past 145 years of this small section of the city and to record, through intensive research and carefully controlled archaeology, details of everyday life that would otherwise never have been preserved. Careful cross-checking of published histories, biographies, newspaper articles, personal interviews, and public records against the evidence found in the ground yields a surprisingly accurate picture of exactly what happened on a given historic site at a particular time.

The accumulation of information contained in Volume I was vital in planning the archaeological testing and mitigation phases of the project. Location of test units and trenches depended almost entirely on the information gained by Uecker's map and deed record research, as well as the oral histories recorded by Pfeiffer and transcribed by the staff of E. L. Fly and Associates. Interpretation of the results of the excavations depended heavily on an understanding of the historical and ethnic contexts revealed by the research of Cox and Mock. The detailed recording of the architectural record by Perez and Associates preserved a visual study of the types of modest homes built in the San Antonio area in the late 1880s to the 1930s. From this, Fox has derived a typology which may be useful for application in similar neighborhoods elsewhere in the city.

We were most fortunate to have such detailed and plentiful background information with which to work. The sequence followed on this project-intensive research before planning excavations-has proven itself in earlier CAR projects as an efficient use of excavation time and effort, as well as contributing to a better understanding of the excavation results.

The initial planning for the development of a research strategy for the Alamodome project was based on what had been learned from the research and investigations for the Las Tiendas project, later known as the Rivercenter Mall. Although considerably smaller in scope, being two city blocks, the Las Tiendas Project presented essentially the same problems in urban recovery as the larger Alamodome project. As with the Las Tiendas, a historic sequence of development was postulated based upon the known historic growth of the Alamodome study area. It was initially assumed, from the records available at the beginning of the study, that the area had first remained largely undeveloped until comparatively late, since it had served primarily as the open fields or ejidos for the town. It then began to develop with Alamo Iron Works as a nucleus when that company was forced to move from the downtown area in the mid to late $1800 \mathrm{~s}$. The area then 
experienced further growth with the arrival of the railroad in the 1870s. All of this growth was centered in the first few blocks south of Commerce Street. It was assumed that the residential area to the south of the commercial and industrial area had grown from the settlement of support workers, first for the Iron Works and then later for the railroad. It was also assumed that the area was predominantly occupied by AfricanAmericans, and that it had served as the nucleus of the presently, predominantly black East Side.

In the research for the Rivercenter Shopping Mall, the deed research had to be conducted by a transaction-bytransaction search of the deed records. However, in the case of the Alamodome project, this was recognized as impractical due to the sheer volume of records involved. The Alamodome project entailed over 200 individual lots, with a probability of twenty to thirty transfers for each lot during the period of concern for the study. Therefore, an abstract of title company was engaged to provide the data for the deed record history of the entire area. While this was being developed and studied, a complete set of Sanborn Insurance maps were copied for study and planning. The earliest complete coverage of the area was not until 1886. The next major changes in the area were evident in the 1904 series, the 1930 series, and finally the 1950-to-present series. It was decided, for purposes of this project, to break the historical development into four basic periods: prior to 1860 , 1860 to 1880,1880 to 1900 , and 1900 to the present. For the first period, we were forced to rely on the Koch 1873 bird's eye view of San Antonio. We also used evidences of early construction indicated by type of construction shown on the 1904 Sanborn map, such as those structures indicated as "adobe," those comparatively small in size and of known early architectural plan. These were preliminary judgments to be verified by the results of the title search. The following period constructions were then identified by their appearance on the maps and their architectural style. From the results of this study, a tentative selection of potential sites was developed.

Once the title search was completed, the list of owners was examined to identify any sites that have potential historic importance that would lend themselves to National Register consideration. The preliminary site list was then narrowed by selection of specific considerations of interest within the overall project proposal. It soon became evident that some of our initial assumptions concerning the development of the area were at fault. First, the occupation of the area was initially almost exclusively blue-collar, semi-skilled to skilled German and Polish workers. There was virtually no segregation within the area, but the few Black families were evenly dispersed within the individual blocks. The area then later changed in ethnic diversity by an influx of Hispanic families, and did not become predominantly black until recent times, and then only in the southern portion of the Alamodome site. Our study indicated the African-American settlement of the area was further east and to some extent to the north of the study area.

Once the history of development was clarified, individual sites that had been selected as having potential merit were then narrowed down by the criteria selected in the initial scope of work. These sites were then appraised based upon their uniqueness and location within the study area. It was recognized that with the short framework of time remaining, after planning and budget delays, it would be necessary to initially concentrate on those sites within the footprint, or the actual area impacted by the Alamodome structure, in order to recover all required information without adverse impact upon the construction deadlines. These sites were scheduled first for investigation, which was initiated while the demolition and site clearance were being monitored by other members of the archaeological team. The areas selected for possible extensive study and mitigation were selected as much as possible outside the footprint area, selecting by comparison of attributes and where possible with substitution of like sites within the area to be impacted last.

\section{Developmental History of Lots Within the Project Area}

Tables 7-1 and 7-2 summarize the developmental history of all 242 lots in the Alamodome project area from 1850 to 1950 . Maps of the area and a variety of other archival sources were used to assign site types to each lot-limited to undeveloped/vacant, residential, commercial, industrial, or unknown. Since individual lot- site types changed frequently through time, each lot was examined in arbitrarily selected, five-year increments. Thus, each lot had 21 temporal units; the 
entire project area had 5,082 spatial-temporal units. Table 7-1 presents the site-type changes over time for all of the lots. Table 7-2 shows the proportion of each site type for the project area at different time periods. Similar calculations were also made for each block and are presented in Table 7-3.

This method of analysis created a few inconsistencies and problems. First, to limit the number of potential types of sites, mixed-use sites (i.e., a lot that had commercial and residential components) were counted only as a single type. Lots that were commercial and residential were recorded as commercial; lots that were industrial and commercial were recorded as industrial. No other mixed-use types (i.e., industrialresidential) were identified. Second, when a site changed type at an unknown time (from residential to industrial, for example), the intervening years were recorded as unknown. Therefore, the unknown category is slightly overrepresented. Despite these limitations, Tables 7-1, 7-2, and 7-3 provide reasonably accurate overviews of the project area's development.

As Table 7-2 illustrates, site types were identified for nearly 66 percent of the spatial-temporal units while 34 percent were unknown. Likewise, full lot histories (where site types could be identified for all 21 temporal units) were completed for 85 of the 242 lots (35.12 percent [Table 7-1]). Full lot histories were also completed for 30 of the 36 archaeological sites (note that the 36 sites occupied 47 lots). Only six lots (2.48 percent) have fully incomplete or unknown developmental histories.

Until the early twentieth century, much of the project area was undeveloped. For instance, in 1870 at least 57 percent of all of the lots were undeveloped. If the data are adjusted to reflect only the identified sites by subtracting out the unknown sites, undeveloped lots in 1870 constituted 88 percent of all known sites. Similar calculations were completed for all known site types for 1870,1910 , and 1950 and are presented in Table $7-4$.

Residential development in the Alamodome area probably peaked in 1910 when at least 52 percent of the lots were used for residential purposes. However, a larger percentage of the lots were residential before the turn of the century than is suggested in Table 7-2.
Our most complete data was for years where detailed maps were available (1886, 1904, 1911, and 1952). Therefore, the difference between map years and periods immediately prior to map years are slightly exaggerated. A more accurate reflection of the area's early residential development can be completed by calculating adjusted rates for known sites for the years just prior to 1905-1910. In 1880, residential lots constituted 23.18 percent of all known sites; in 1885 , 25.80 percent; in $1900,42.11$ percent; in $1905,43.75$ percent; and in 1910, 62.19 percent.

The area developed few commercial properties. After the turn of the century, between one and three percent of the lots were used for commercial purposes. No more than 10 percent of the lots were industrial before 1900. After the turn of the century, however, a large percentage of the project area was used for industrial purposes. By 1950 , almost 50 percent of all of the lots were industrial. Table 7-3 suggests that residential and industrial lots were intentionally segregated. Blocks that were predominantly industrial-including NCBs $601,614,679,681$, and 682-had few, if any, known residential lots.

In general, the project area developed in four phases: Early Residential Development (1850 to 1860), Residential Growth and Early Industrial Development (1860 to 1880), Residential Climax (1880 to 1900), and Industrial Infusion (1900 to 1950). We intuitively selected a representative sample of residential sites from different time periods to archaeologically investigate. Nine of the archaeological sites were constructed between 1850 and ca. 1859; 3 sites were constructed between 1860 and 1879; 13 sites were constructed between 1880 and ca. 1889; and, 11 sites were constructed between 1900 and 1950 . Collectively, the selected sites allowed us to examine the entire area's development over time. 
Table 7-1. Developmental History of Lots in the Alamodome Project Area, 1850-1950

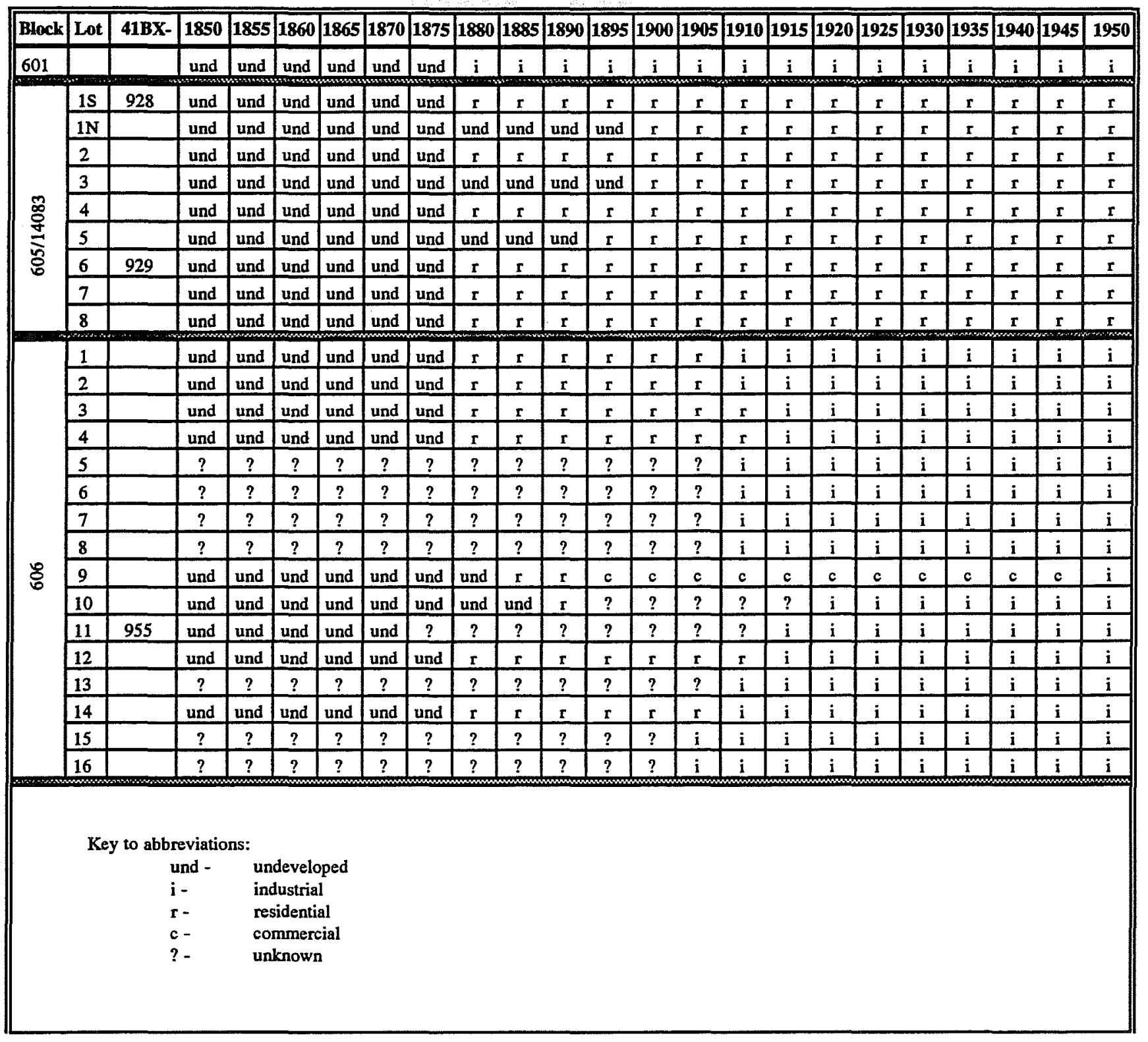


Table 7-1. continued

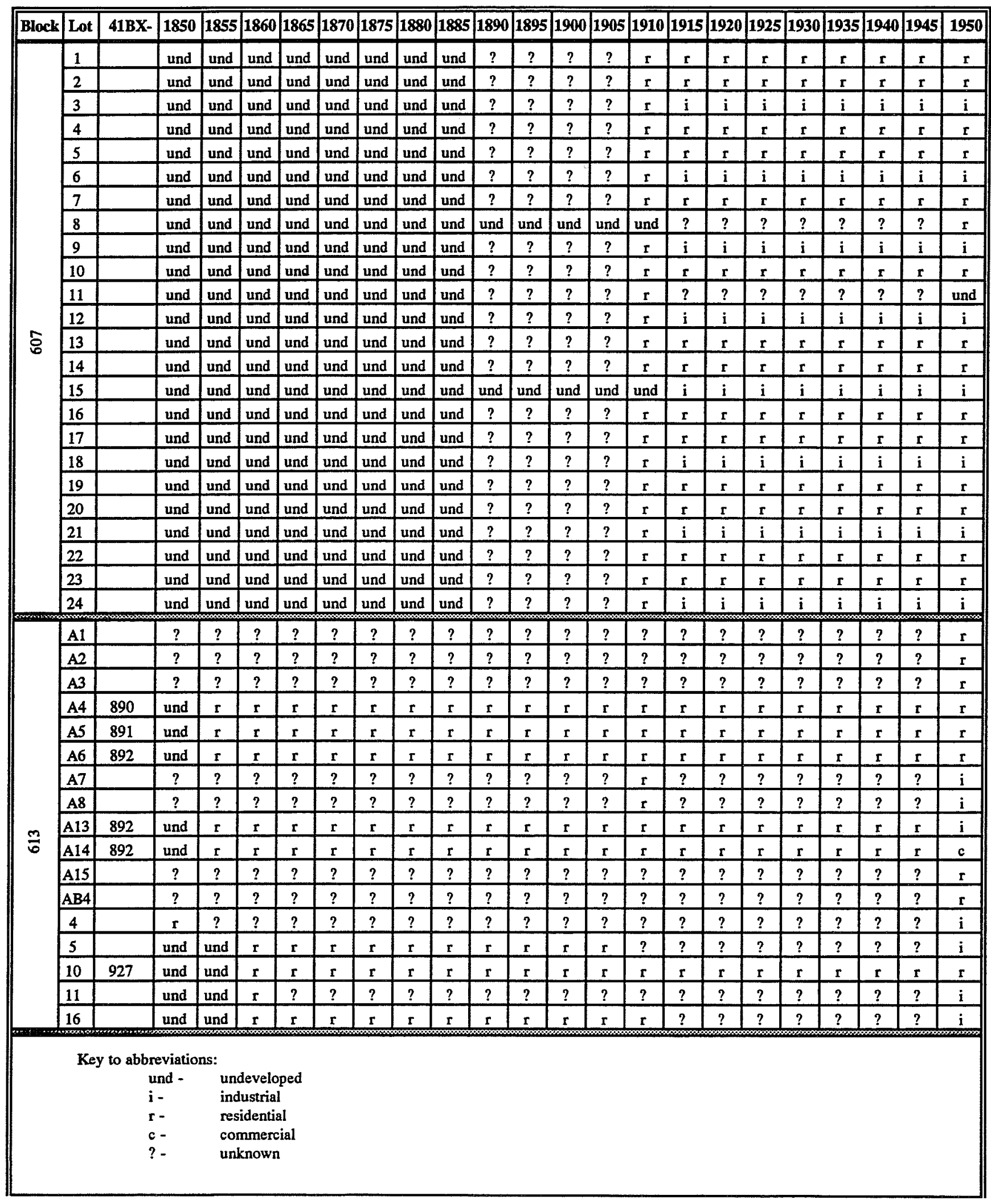


Table 7-1. continued

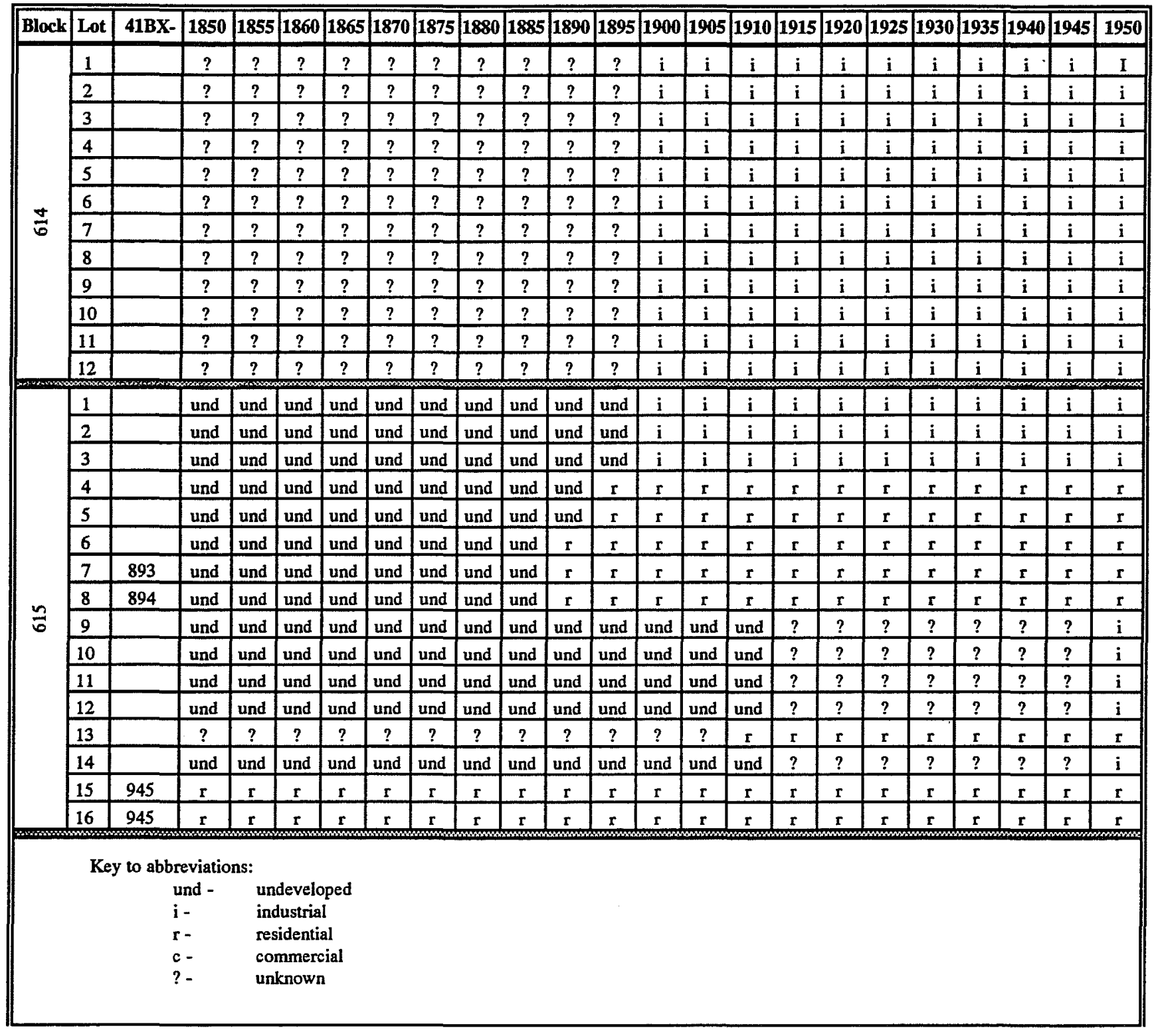


Table 7-1. continued

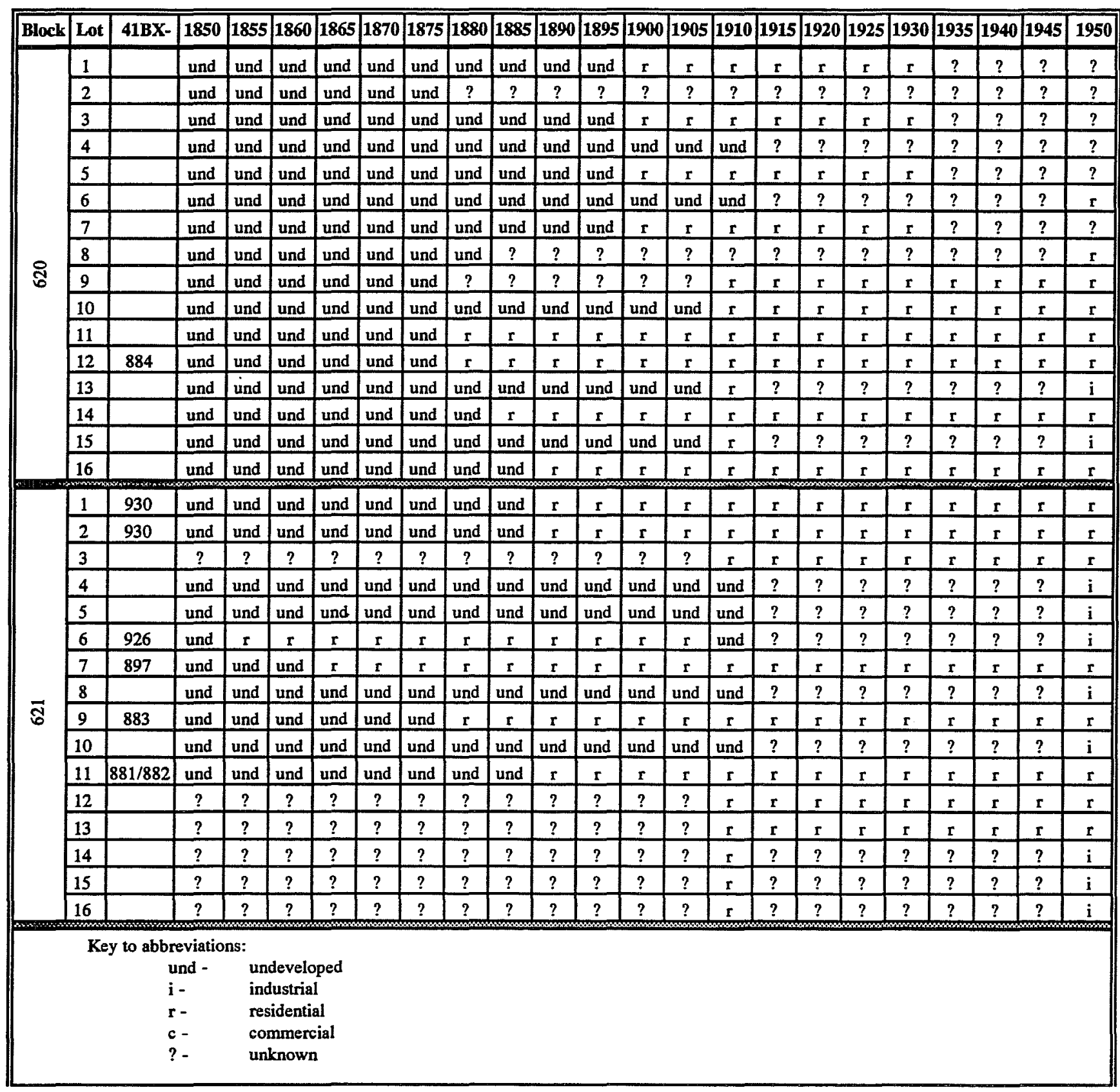


Table 7-1. continued

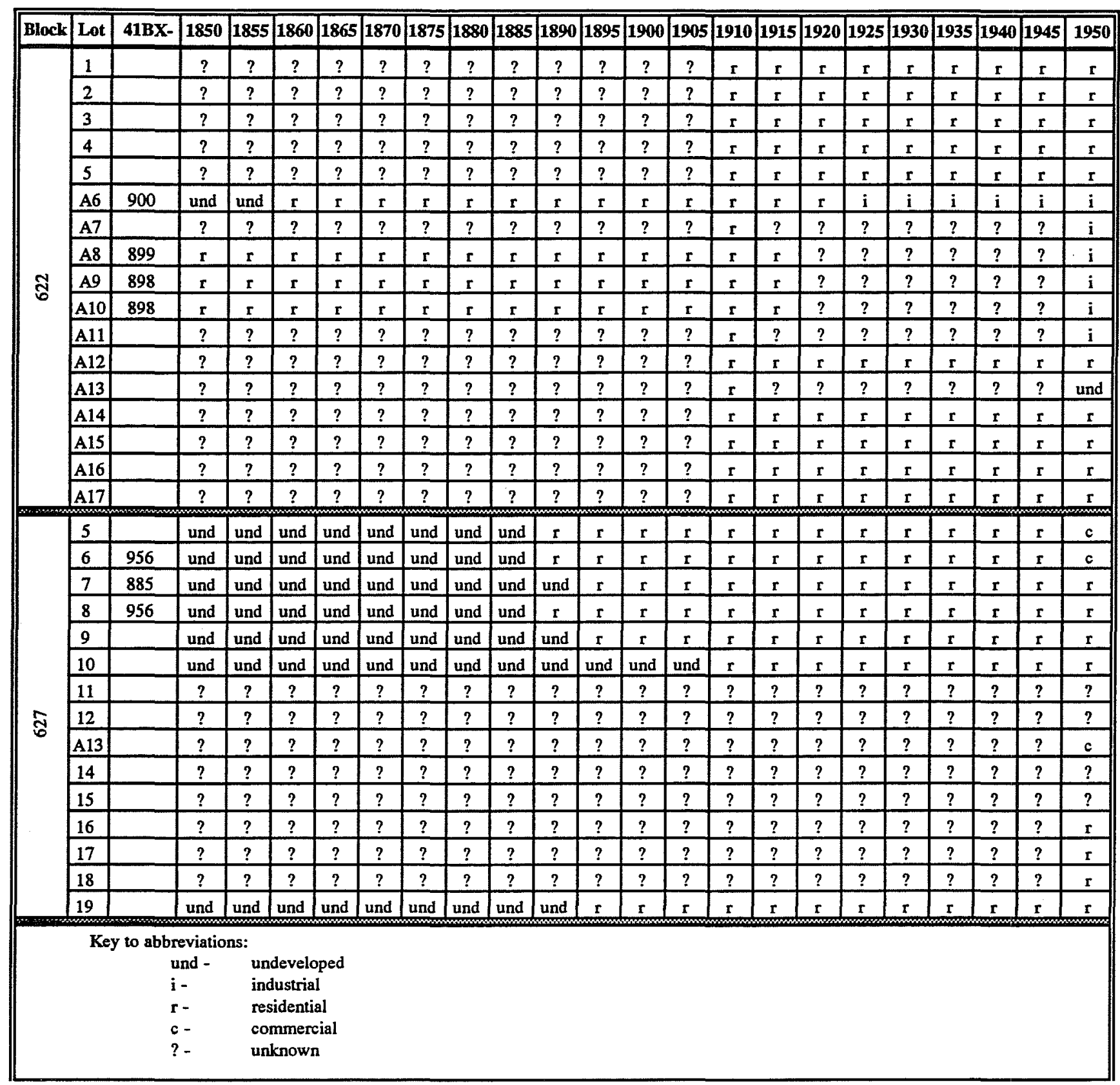


Table 7-1. continued

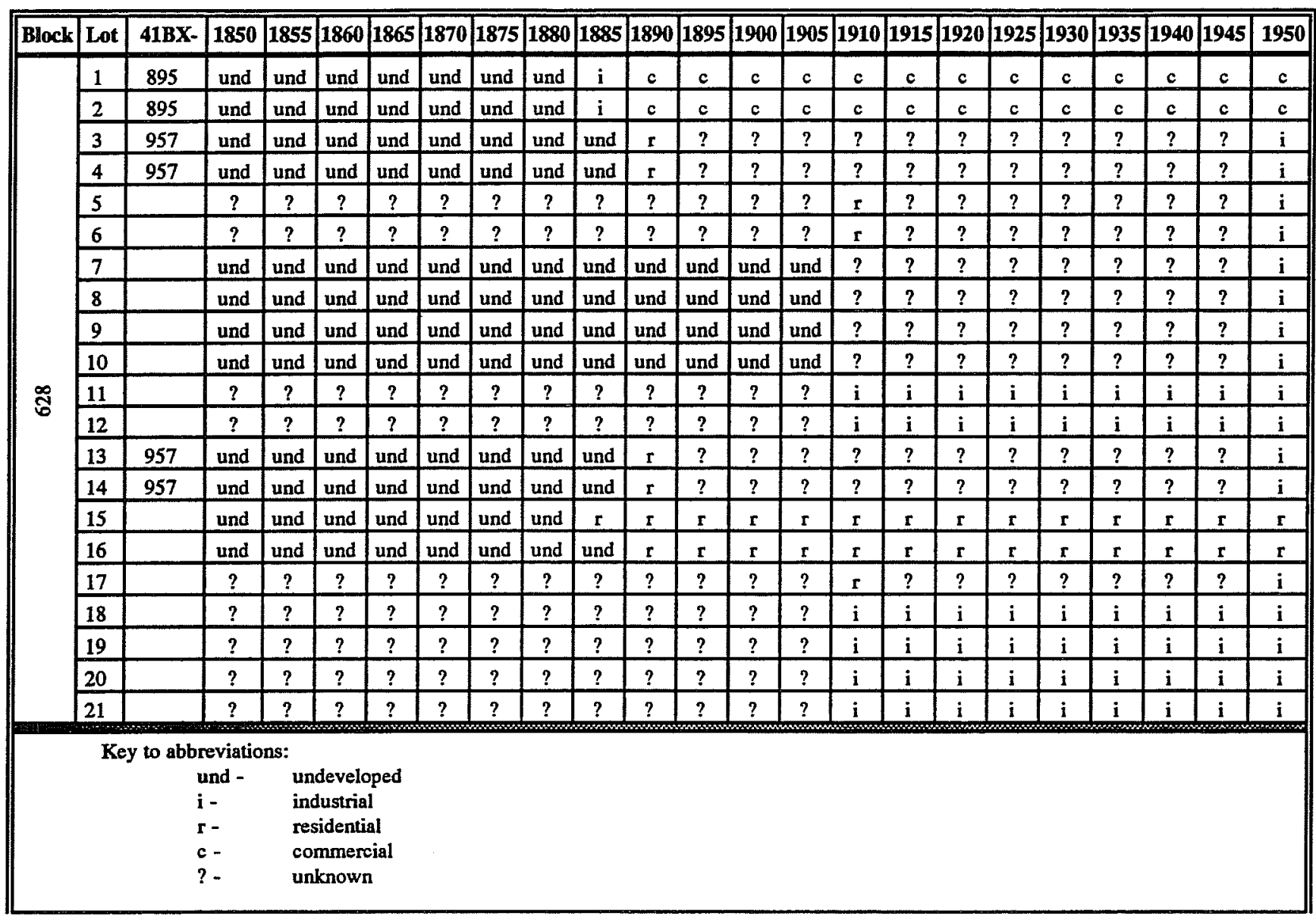


Table 7-1. continued

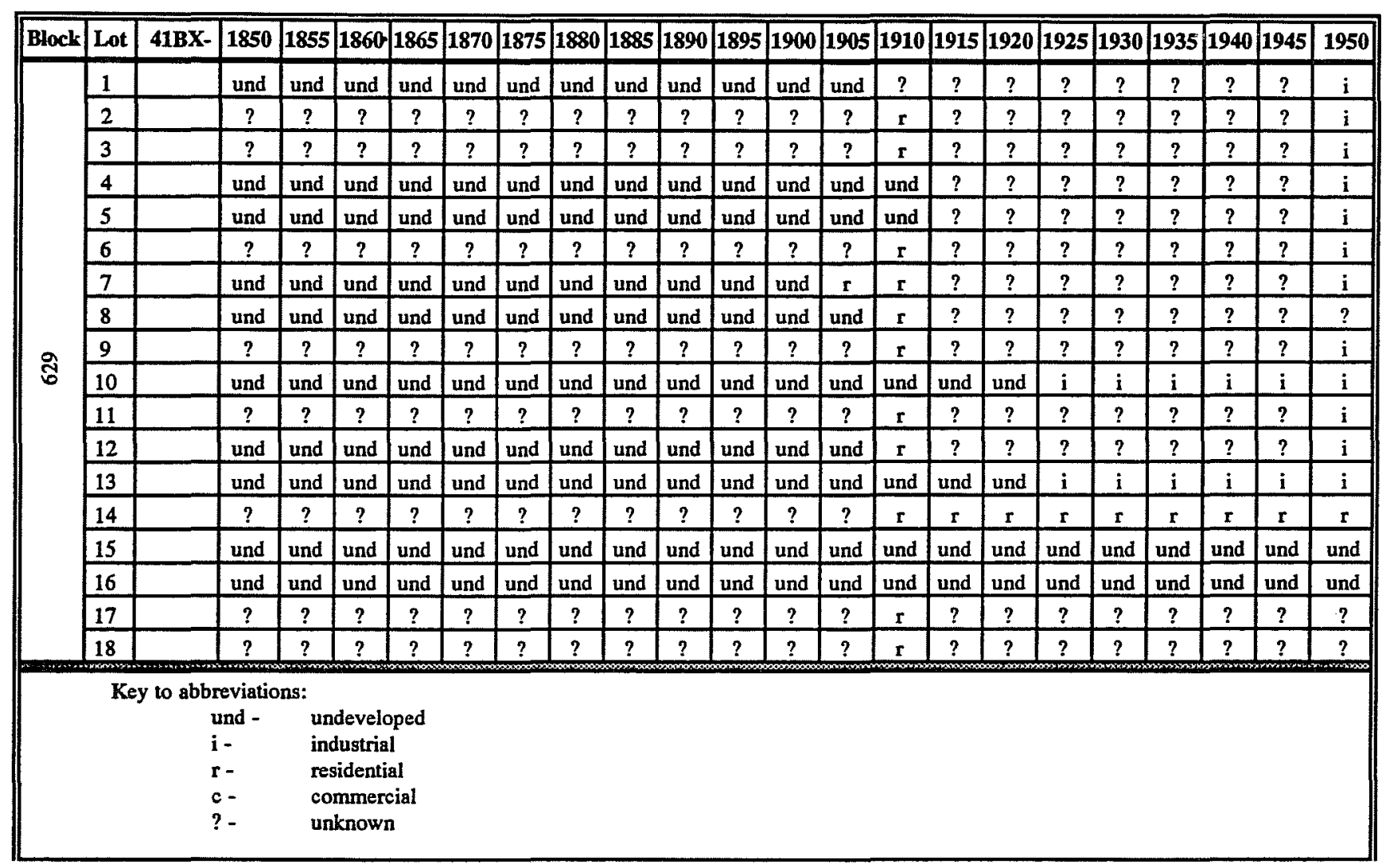


Table 7-1. continued

\begin{tabular}{|c|c|c|c|c|c|c|c|c|c|c|c|c|c|c|c|c|c|c|c|c|c|c|c|}
\hline Block & Lot & 41BX- & 1850 & 1855 & 1860 & 1865 & 1870 & 1875 & 1880 & 1885 & 1890 & 1895 & 1900 & 1905 & 1910 & 1915 & 1920 & 1925 & 1930 & 1935 & 1940 & 1945 & 1950 \\
\hline \multirow{30}{*}{ ర্ঠి } & 1 & & $?$ & $?$ & $?$ & $?$ & $?$ & $?$ & $?$ & $?$ & $?$ & $?$ & $?$ & $?$ & $?$ & $?$ & $?$ & $?$ & $?$ & $?$ & $?$ & $?$ & $?$ \\
\hline & 2 & & $?$ & $?$ & $?$ & $?$ & $?$ & $?$ & $?$ & $?$ & $?$ & $?$ & $?$ & $?$ & $r$ & $\mathbf{r}$ & $\mathbf{r}$ & $r$ & $r$ & $\mathbf{r}$ & $\mathbf{r}$ & $\mathbf{r}$ & $\mathbf{r}$ \\
\hline & 3 & & $?$ & $?$ & $?$ & $?$ & $?$ & $?$ & $?$ & $?$ & $?$ & $?$ & $?$ & $?$ & $\mathbf{r}$ & $\mathbf{r}$ & $I$ & $\mathbf{r}$ & $r$ & $I$ & $\mathbf{r}$ & $\mathbf{r}$ & $\boldsymbol{I}$ \\
\hline & 4 & 896 & $r$ & $r$ & $r$ & $r$ & $r$ & $\mathbf{r}$ & $\mathbf{r}$ & $r$ & $r$ & $r$ & $\mathbf{r}$ & $r$ & $\mathbf{r}$ & $r$ & $r$ & $\mathbf{r}$ & $\mathbf{r}$ & $\mathbf{r}$ & $\mathbf{r}$ & $\mathbf{r}$ & $r$ \\
\hline & 5 & 896 & $\mathbf{r}$ & $\mathbf{r}$ & $r$ & $r$ & $\mathbf{r}$ & 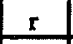 & $r$ & $r$ & $r$ & $\mathbf{r}$ & $\mathbf{r}$ & $\underline{I}$ & $\mathbf{r}$ & $r$ & $\mathbf{r}$ & $\boldsymbol{r}$ & $r$ & $r$ & $\mathbf{r}$ & $r$ & $\mathbf{r}$ \\
\hline & 6 & & $?$ & $?$ & $?$ & $?$ & $?$ & $?$ & $?$ & $?$ & $?$ & $?$ & $?$ & $?$ & $\mathbf{r}$ & $\boldsymbol{r}$ & $\mathbf{r}$ & $\mathbf{r}$ & $\mathbf{r}$ & $\mathbf{r}$ & $\mathbf{r}$ & $\mathbf{r}$ & $\mathbf{r}$ \\
\hline & 7 & 938 & $?$ & $?$ & $?$ & $?$ & $?$ & $?$ & $\mathbf{r}$ & $r$ & $r$ & $\mathbf{r}$ & $r$ & $\mathbf{r}$ & $r$ & $\underline{I}$ & $\mathbf{r}$ & $\mathbf{r}$ & $\mathbf{I}$ & $r$ & $r$ & $\mathbf{r}$ & r \\
\hline & A8 & 937 & $?$ & $?$ & $?$ & $?$ & $?$ & $?$ & $\mathbf{r}$ & $r$ & $I$ & r & $\mathbf{r}$ & $r$ & $\mathbf{r}$ & $\mathbf{r}$ & $\mathbf{r}$ & $\mathbf{r}$ & $\mathbf{r}$ & $\mathbf{r}$ & $\mathbf{r}$ & $\mathbf{r}$ & $\mathbf{r}$ \\
\hline & A9 & & $\stackrel{?}{?}$ & $?$ & $?$ & $?$ & $?$ & $?$ & $?$ & $?$ & $?$ & $?$ & $?$ & $?$ & $r$ & $\mathbf{r}$ & $\mathbf{r}$ & $I$ & $\mathbf{r}$ & $\mathbf{r}$ & $\mathbf{r}$ & $r$ & $\mathbf{r}$ \\
\hline & 17 & & $?$ & $?$ & $?$ & $?$ & $?$ & $?$ & $?$ & $?$ & $?$ & $?$ & $?$ & $?$ & $r$ & $\mathbf{r}$ & $r$ & $\boldsymbol{r}$ & $r$ & $r$ & $\mathbf{r}$ & $\mathbf{r}$ & $r$ \\
\hline & 18 & & $?$ & $?$ & $?$ & $?$ & $?$ & $?$ & $?$ & $?$ & $?$ & $?$ & $?$ & $?$ & $?$ & $?$ & $?$ & $?$ & $?$ & $?$ & $?$ & $?$ & $r$ \\
\hline & $\mathbf{A}$ & & und & und & und & und & und & und & und & und & und & und & und & und & $?$ & $?$ & $?$ & $?$ & $?$ & $?$ & $?$ & $?$ & r \\
\hline & B & & und & und & und & und & und & und & und & und & und & und & und & und & $?$ & $?$ & $?$ & $?$ & $?$ & $?$ & $?$ & $?$ & $\mathbf{r}$ \\
\hline & C & 932 & und & und & und & und & und & und & und & und & und & und & und & und & und & und & $r$ & $r$ & $r$ & $r$ & $r$ & $\Gamma$ & $r$ \\
\hline & D & 931 & und & und & und & und & und & und & und & und & und & und & und & und & und & und & $r$ & $r$ & $\mathbf{r}$ & $\mathbf{r}$ & $\mathbf{r}$ & $\mathbf{r}$ & $r$ \\
\hline & $\mathbf{E}$ & & und & und & und & und & und & und & und & und & und & und & und & und & $?$ & $?$ & $?$ & $?$ & $?$ & $?$ & $?$ & $?$ & $\boldsymbol{r}$ \\
\hline & $\mathbf{F}$ & & und & und & und & und & und & und & und & und & und & und & und & und & $?$ & $?$ & $?$ & $?$ & $?$ & $?$ & $?$ & $?$ & $r$ \\
\hline & $\mathbf{G}$ & & und & und & und & und & und & und & und & und & und & und & und & und & $?$ & $?$ & $?$ & $?$ & $?$ & $?$ & $?$ & $?$ & $r$ \\
\hline & H & 936 & und & und & und & und & und & und & $I$ & r & $r$ & $\mathbf{r}$ & $\mathbf{r}$ & $\mathbf{r}$ & $r$ & $r$ & $r$ & $r$ & $\mathbf{r}$ & $r$ & $r$ & $r$ & $r$ \\
\hline & I & 936 & und & und & und & und & und & und & I & $\mathbf{r}$ & $r$ & $\mathbf{r}$ & $\mathbf{r}$ & $\mathbf{r}$ & $r$ & $\mathbf{r}$ & $r$ & $r$ & $r$ & $r$ & $\boldsymbol{r}$ & $r$ & $r$ \\
\hline & $\mathbf{J}$ & 942 & und & und & und & und & und & und & und & und & und & und & und & und & und & und & $r$ & $\mathbf{r}$ & $r$ & $r$ & $\mathbf{r}$ & $\mathbf{r}$ & $r$ \\
\hline & $\mathbf{K}$ & & und & und & und & und & und & und & und & und & und & und & und & und & und & und & $r$ & $\mathbf{r}$ & r & $r$ & $\mathbf{r}$ & $r$ & $\mathbf{r}$ \\
\hline & $\mathbf{L}$ & 941 & und & und & und & und & und & und & und & und & und & und & und & und & und & und & $r$ & $r$ & $\mathbf{r}$ & $\mathbf{r}$ & $\mathbf{r}$ & $\mathbf{r}$ & $\mathbf{r}$ \\
\hline & $\mathbf{M}$ & 944 & und & und & und & und & und & und & und & und & und & und & und & und & und & und & $r$ & $\mathbf{r}$ & $\mathbf{r}$ & $r$ & $\mathbf{r}$ & I & $r$ \\
\hline & $\mathbf{N}$ & 939 & und & und & und & und & und & und & und & und & und & und & und & und & und & und & $\underline{r}$ & $\mathbf{r}$ & $I$ & $I$ & $\mathbf{r}$ & $\mathbf{r}$ & $r$ \\
\hline & 0 & & und & und & und & und & und & und & und & und & und & und & und & und & und & und & $r$ & r & $r$ & $\mathbf{r}$ & $r$ & $r$ & $\mathbf{r}$ \\
\hline & $\mathbf{P}$ & 940 & und & und & und & und & und & und & und & und & und & und & und & und & und & und & $r$ & $\mathbf{r}$ & $\mathbf{r}$ & $\mathbf{r}$ & $\mathbf{r}$ & $\mathbf{r}$ & $\mathbf{r}$ \\
\hline & $Q$ & 943 & und & und & und & und & und & und & und & und & und & und & und & und & und & und & $r$ & $\mathbf{r}$ & $I$ & $r$ & $r$ & $\mathbf{r}$ & $r$ \\
\hline & $\mathbf{R}$ & & und & und & und & und & und & und & und & und & und & und & und & und & $?$ & $?$ & $?$ & $?$ & $?$ & $?$ & $?$ & $?$ & $\mathbf{r}$ \\
\hline & $s$ & & und & und & und & und & und & und & und & und & und & und & und & und & $?$ & $?$ & $?$ & $?$ & $?$ & $?$ & $?$ & $?$ & $r$ \\
\hline 679 & & & und & und & und & und & und & und & und & und & und & und & $\mathrm{i}$ & $i$ & $i$ & $i$ & $i$ & i & i & $i$ & $i$ & i & $i$ \\
\hline \multirow{10}{*}{$\vec{\infty}$} & $?$ & & und & und & und & und & und & und & und & und & und & und & $\mathrm{i}$ & $\mathrm{i}$ & i & $\mathrm{i}$ & $i$ & i & i & $i$ & $\mathbf{i}$ & $\mathrm{i}$ & i \\
\hline & $?$ & & und & und & und & und & und & und & und & und & und & und & $\mathrm{i}$ & $\mathrm{i}$ & $\mathrm{i}$ & $\mathbf{i}$ & $\mathrm{i}$ & $\mathbf{i}$ & $\mathbf{i}$ & $\mathrm{i}$ & $\mathrm{i}$ & $\mathrm{i}$ & i \\
\hline & $?$ & & und & und & und & und & und & und & und & und & und & und & i & $\mathrm{i}$ & i & $\mathbf{i}$ & i & $\mathbf{i}$ & $\mathrm{i}$ & i & i & i & $\mathbf{i}$ \\
\hline & $?$ & & und & und & und & und & und & und & und & und & und & und & i & $\mathrm{i}$ & i & $\mathrm{i}$ & i & i & $i$ & i & $i$ & $\mathrm{i}$ & i \\
\hline & $?$ & & und & und & und & und & und & und & und & und & und & und & $i$ & $\mathrm{i}$ & $\mathrm{i}$ & $\mathrm{i}$ & $\mathrm{i}$ & $\mathrm{i}$ & i & $\mathbf{i}$ & $\mathrm{i}$ & i & i \\
\hline & $?$ & & und & und & und & und & und & und & und & und & und & und & $\mathrm{i}$ & $\mathrm{i}$ & $\mathbf{i}$ & $i$ & $\mathrm{i}$ & $\mathbf{i}$ & $\mathbf{i}$ & $\mathbf{i}$ & $i$ & $\mathbf{i}$ & $\mathbf{i}$ \\
\hline & $?$ & & und & und & und & und & und & und & und & und & und & und & $\mathbf{i}$ & $\mathrm{i}$ & $i$ & $\mathbf{i}$ & $\mathbf{i}$ & i & $\mathrm{i}$ & $\mathbf{i}$ & $\mathrm{i}$ & $\mathbf{i}$ & $\mathbf{i}$ \\
\hline & $?$ & & und & und & und & und & und & und & und & und & und & und & $\mathbf{i}$ & $\mathrm{i}$ & $\mathrm{i}$ & $\mathrm{i}$ & i & $\mathrm{i}$ & $\mathrm{i}$ & $\mathbf{i}$ & $i$ & i & $\mathbf{i}$ \\
\hline & $?$ & & und & und & und & und & und & und & und & und & und & und & $\mathrm{i}$ & i & $\mathrm{i}$ & i & $\mathrm{i}$ & $\mathbf{i}$ & i & i & $\mathrm{i}$ & $\mathbf{i}$ & i \\
\hline & $?$ & & und & und & und & und & und & und & und & und & und & und & $i$ & i & $i$ & $\mathbf{i}$ & i & $\mathbf{i}$ & i & i & $\mathrm{i}$ & $\mathbf{i}$ & i \\
\hline \multirow{3}{*}{ 话 } & 6 & & $?$ & $?$ & $?$ & $?$ & $?$ & $?$ & $?$ & $?$ & $?$ & $?$ & $?$ & $?$ & $?$ & $?$ & $?$ & $?$ & $?$ & $?$ & $?$ & $?$ & $?$ \\
\hline & 7 & & $?$ & $?$ & $?$ & $?$ & $?$ & $?$ & $?$ & $?$ & $?$ & $?$ & $?$ & $?$ & $?$ & $?$ & i & $\mathbf{i}$ & $i$ & i & i & $\mathbf{i}$ & i \\
\hline & 8 & & $?$ & $?$ & $?$ & $?$ & $?$ & $?$ & $?$ & $?$ & $?$ & $?$ & $?$ & $?$ & $?$ & $?$ & i & i & i & i & $\mathrm{i}$ & i & i \\
\hline \multicolumn{24}{|c|}{ 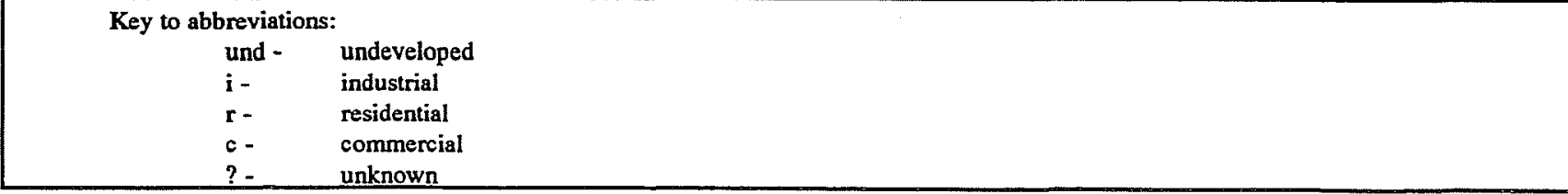 } \\
\hline
\end{tabular}


Table 7-2. Summary of Development of Lots within the Alamodome Project Area

\begin{tabular}{|c|c|c|c|c|c|c|c|c|c|c|c|c|c|c|c|c|c|c|c|c|c|}
\hline \multicolumn{2}{|r|}{ Lot Use } & 1850 & 1855 & 1860 & 1865 & 1870 & 1875 & 1880 & 1885 & 1890 & 1895 & 1900 & 1910 & 1915 & 1920 & 1925 & 1930 & 1935 & 1940 & 1945 & 1950 \\
\hline \multirow{6}{*}{ 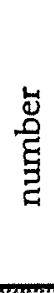 } & undeveloped & 151 & 145 & 140 & 139 & 139 & 138 & 118 & 112 & 74 & 68 & 48 & 30 & 14 & 4 & 2 & 2 & 2 & 2 & 2 & 4 \\
\hline & residential & 8 & 13 & 18 & 18 & 18 & 18 & 37 & 40 & 56 & 56 & 62 & 125 & 90 & 97 & 96 & 96 & 92 & 92 & 92 & 107 \\
\hline & commercial & 0 & 0 & 0 & 0 & 0 & 0 & 0 & 0 & 2 & 3 & 3 & 3 & 3 & 3 & 3 & 3 & 3 & 3 & 3 & 6 \\
\hline & industrial & 0 & 0 & 0 & 0 & 0 & 0 & 1 & 3 & 1 & 1 & 27 & 43 & 55 & 58 & 61 & 61 & 61 & 61 & 61 & 110 \\
\hline & unknown & 83 & 84 & 84 & 85 & 85 & 86 & 86 & 87 & 109 & 114 & 102 & 41 & 80 & 80 & 80 & 80 & 84 & 84 & 84 & 15 \\
\hline & total & 242 & 242 & 242 & 242 & 242 & 242 & 242 & 242 & 242 & 242 & 242 & 242 & 242 & 242 & 242 & 242 & 242 & 242 & 242 & 242 \\
\hline \multirow{6}{*}{$d^{\circ}$} & undeveloped & 62.4 & 59.9 & 57.9 & 57.4 & 57.4 & 57 & 48.8 & 46.3 & 30.6 & 28.1 & 19.8 & 12.4 & 5.79 & 1.65 & 0.83 & 0.83 & 0.83 & 0.83 & 0.83 & 1.65 \\
\hline & residential & 3.31 & 5.37 & 7.44 & 7.44 & 7.44 & 7.44 & 15.3 & 16.5 & 23.1 & 23.1 & 25.6 & 51.7 & 37.2 & 40.1 & 39.7 & 39.7 & 38 & 38 & 38 & 44.2 \\
\hline & commercial & 0 & 0 & 0 & 0 & 0 & 0 & 0 & 0 & 0.83 & 1.24 & 1.24 & 1.24 & 1.24 & 1.24 & 1.24 & 1.24 & 1.24 & 1.24 & 1.24 & 2.48 \\
\hline & industrial & 0 & 0 & 0 & 0 & 0 & 0 & 0.41 & 1.24 & 0.41 & 0.41 & 11.2 & 17.8 & 22.7 & 24 & 25.2 & 25.2 & 25.2 & 25.2 & 25.2 & 45.5 \\
\hline & unknown & 34.3 & 34.7 & 34.7 & 35.1 & 35.1 & 35.5 & 35.5 & 36 & 45 & 47.1 & 42.2 & 16.9 & 33.1 & 33.1 & 33.1 & 33.1 & 34.7 & 34.7 & 34.7 & 6.2 \\
\hline & total & 100 & 100 & 100 & 100 & 100 & 100 & 100 & 100 & 100 & 100 & 100 & 100 & 100 & 100 & 100 & 100 & 100 & 100 & 100 & 100 \\
\hline
\end{tabular}


Table 7-3. Summary of Developmental History of Lots Within the Alamodome Project Area by Blocks

\begin{tabular}{|c|c|c|c|c|c|c|c|c|}
\hline Block & Lots & ST Units & Sites & $\begin{array}{l}\text { Undeveloped } \\
(n=)\end{array}$ & $\begin{array}{c}\text { Residential } \\
(\mathbf{n}=)\end{array}$ & $\begin{array}{c}\text { Commercial } \\
(\mathbf{n}=)\end{array}$ & $\begin{array}{c}\text { Industrial } \\
(\mathbf{n}=)\end{array}$ & $\begin{array}{c}\text { Unkmown } \\
(\mathbf{n}=)\end{array}$ \\
\hline 601 & 1 & 21 & 0 & 6 & 0 & 0 & 15 & 0 \\
\hline 605 & 9 & 189 & 2 & 65 & 124 & 0 & 0 & 0 \\
\hline 606 & 16 & 336 & 1 & 56 & 42 & 11 & 132 & 95 \\
\hline 607 & 24 & 504 & 0 & 203 & 135 & 0 & 64 & 102 \\
\hline 613 & 17 & 357 & 4 & 13 & 147 & 1 & 7 & 189 \\
\hline 614 & 12 & 252 & 0 & 0 & 0 & 0 & 132 & 120 \\
\hline 615 & 16 & 336 & 3 & 137 & 114 & 0 & 38 & 47 \\
\hline 620 & 16 & 336 & 1 & 148 & 107 & 0 & 2 & 79 \\
\hline 621 & 16 & 336 & 6 & 87 & 113 & 0 & 8 & 128 \\
\hline 622 & 17 & 357 & 3 & 3 & 148 & 0 & 11 & 195 \\
\hline 627 & 15 & 315 & 2 & 63 & 85 & 3 & 0 & 164 \\
\hline 628 & 21 & 441 & 2 & 109 & 34 & 26 & 67 & 205 \\
\hline 629 & 18 & 378 & 0 & 145 & 20 & 0 & 22 & 191 \\
\hline 636 & 30 & 630 & 12 & 236 & 225 & 0 & 0 & 169 \\
\hline 679 & 1 & 21 & 0 & 10 & 0 & 0 & 11 & 0 \\
\hline 681 & 10 & 210 & 0 & 100 & 0 & 0 & 110 & 0 \\
\hline 682 & 3 & 63 & 0 & 0 & 0 & 0 & 14 & 49 \\
\hline & 242 & 5082 & 36 & 1381 & 1294 & 41 & 633 & 1733 \\
\hline Block & Lots & ST Units & Sites & $\begin{array}{c}\text { Undeveloped } \\
(\%)\end{array}$ & $\begin{array}{c}\text { Residential } \\
(\%)\end{array}$ & $\begin{array}{c}\text { Commercial } \\
(\%)\end{array}$ & $\begin{array}{c}\text { Industrial } \\
(\%)\end{array}$ & $\begin{array}{c}\text { Unknown } \\
(\%) \\
\end{array}$ \\
\hline 601 & 1 & 21 & 0 & 28.57 & 0.00 & 0.00 & 71.43 & 0.00 \\
\hline 605 & 9 & 189 & 2 & 34.39 & 65.61 & 0.00 & 0.00 & 0.00 \\
\hline 606 & 16 & 336 & 1 & 16.67 & 12.50 & 3.27 & 39.29 & 28.27 \\
\hline 607 & 24 & 504 & 0 & 40.28 & 26.79 & 0.00 & 12.70 & 20.24 \\
\hline 613 & 17 & 357 & 4 & 3.64 & 41.18 & 0.28 & 1.96 & 52.94 \\
\hline 614 & 12 & 252 & 0 & 0.00 & 0.00 & 0.00 & 52.38 & 47.62 \\
\hline 615 & 16 & 336 & 3 & 40.77 & 33.93 & 0.00 & 11.31 & 13.99 \\
\hline 620 & 16 & 336 & 1 & 44.05 & 31.85 & 0.00 & 0.60 & 23.51 \\
\hline 621 & 16 & 336 & 6 & 25.89 & 33.63 & 0.00 & 2.38 & 38.10 \\
\hline 622 & 17 & 357 & 3 & 0.84 & 41.46 & 0.00 & 3.08 & 54.62 \\
\hline 627 & 15 & 315 & 2 & 20.00 & 26.98 & 0.95 & 0.00 & 52.06 \\
\hline 628 & 21 & 441 & 2 & 24.72 & 7.71 & 5.90 & 15.19 & 46.49 \\
\hline 629 & 18 & 378 & 0 & 38.36 & 5.29 & 0.00 & 5.82 & 50.53 \\
\hline 636 & 30 & 630 & 12 & 37.46 & 35.71 & 0.00 & 0.00 & 26.83 \\
\hline 679 & 1 & 21 & 0 & 47.62 & 0.00 & 0.00 & 52.38 & 0.00 \\
\hline 681 & 10 & 210 & 0 & 47.62 & 0.00 & 0.00 & 52.38 & 0.00 \\
\hline 682 & 3 & 63 & $\underline{\underline{0}}$ & 0.00 & 0.00 & 0.00 & 22.22 & 77.78 \\
\hline
\end{tabular}

Table 7-4. Percent of Known Site Types in the Alamodome Project Area by Time Period

\begin{tabular}{||c|c|c|c|c||}
\hline & $\mathbf{1 8 7 0}$ & $\mathbf{1 9 1 0}$ & $\mathbf{1 9 5 0}$ & Total \\
\hline Undeveloped & 88.54 & 14.93 & 1.76 & 41.24 \\
\hline Residential & 11.46 & 62.19 & 53.23 & 38.64 \\
\hline Commercial & 0.00 & 1.49 & 2.99 & 1.22 \\
\hline Industrial & 0.00 & 21.39 & 48.46 & 18.90 \\
\hline
\end{tabular}



